VILNIAUS GEDIMINO TECHNIKOS UNIVERSITETAS

Justinas BUČYS

MIESTO LOKALIŲ CENTRỤ FUNKCINĖS IR KOMPOZICINÉS STRUKTŨRŲ SĄVEIKA

\title{
DAKTARO DISERTACIJA
}

HUMANITARINIAI MOKSLAI, MENOTYRA $(03 \mathrm{H})$

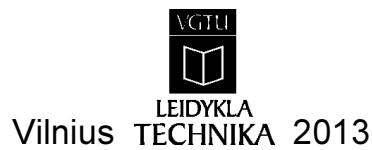


Disertacija rengta 2007-2013 metais Vilniaus Gedimino technikos universitete.

Disertacija ginama eksternu.

Vadovas

prof. dr. Zigmas Jonas DAUNORA (Vilniaus Gedimino technikos universitetas, menotyra - 03H), (2007-2011).

\section{Mokslinis konsultantas}

doc. dr. Gintaras STAUSKIS (Vilniaus Gedimino technikos universitetas, menotyra $-03 \mathrm{H}$ ).

Vilniaus Gedimino technikos universiteto Menotyros mokslo krypties disertacijos gynimo taryba:

\section{Pirmininkas}

prof. habil. dr. Konstantinas JAKOVLEVAS-MATECKIS (Vilniaus

Gedimino technikos universitetas, menotyra -03H).

\section{Nariai:}

doc. dr. Dalia DIJOKIENE (Vilniaus Gedimino technikos universitetas, menotyra $-03 \mathrm{H}$ ),

doc. dr. Jūratė JUREVIČIENĖ (Vilniaus Gedimino technikos universitetas, menotyra $-03 \mathrm{H}$ ),

prof. dr. Janis KRASTINIS (Rygos technikos universitetas, menotyra$03 \mathrm{H})$,

doc. dr. Kęstutis ZALECKIS (Kauno technologijos universitetas, menotyra $03 \mathrm{H})$.

Disertacija bus ginama viešame Menotyros mokslo krypties disertacijos gynimo tarybos poseddyje $\mathbf{2 0 1 3}$ m. lapkričio 7 d. 14 val. Vilniaus Gedimino technikos universiteto senato posèdžių salèje.

Adresas: Sauletekio al. 11, LT-10223 Vilnius, Lietuva.

Tel.: (8 5) 274 4956; faksas (8 5) 270 0112; el. paštas doktor@vgtu.lt

Pranešimai apie numatomą ginti disertaciją išsiųsti $2013 \mathrm{~m}$. spalio $4 \mathrm{~d}$.

Disertaciją galima peržiūrèti interneto svetainèje http://dspace.vgtu.lt ir Vilniaus

Gedimino technikos universiteto bibliotekoje (Sauletekio al. 14, LT-10223 Vilnius, Lietuva).

VGTU leidyklos TECHNIKA 2157-M mokslo literatūros knyga

http://leidykla.vgtu.lt

ISBN 978-609-457-561-7

(C) VGTU leidykla TECHNIKA, 2013

(C) Justinas Bučys, 2013

Justinas.Bucys@vgtu.lt 
VILNIUS GEDIMINAS TECHNICAL UNIVERSITY

Justinas BUČYS

\section{INTERDEPENDENCE BETWEEN FUNCTIONAL AND COMPOSITIONAL STRUCTURES IN THE LOCAL CENTRES OF THE CITY}

DOCTORAL DISSERTATION

HUMANITIES,

HISTORY AND THEORY OF ARTS $(03 \mathrm{H})$

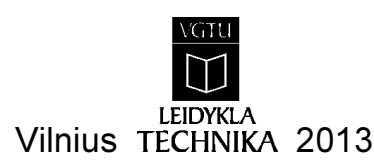


Doctoral dissertation was prepared at Vilnius Gediminas Technical University in 2007-2013.

The dissertation is defended as external work.

\section{Supervisor}

Prof Dr Zigmas Jonas DAUNORA (Vilnius Gediminas Technical University, History and Theory of Arts - 03H), (2007-2011).

\section{Scientific Consultant}

Assoc Prof Dr Gintaras STAUSKIS (Vilnius Gediminas Technical University, History and Theory of Arts $-03 \mathrm{H}$ ).

The Dissertation Defense Council of Scientific Field of History and Theory of Arts of Vilnius Gediminas Technical University:

\section{Chairman}

Prof Dr Habil Konstantinas JAKOVLEVAS-MATECKIS (Vilnius

Gediminas Technical University, History and Theory of Arts $-03 \mathrm{H}$ ).

\section{Members:}

Assoc Prof Dr Dalia DIJOKIENE (Vilnius Gediminas Technical University, History and Theory of Arts - 03H),

Assoc Prof Dr Jūratė JUREVIČIENĖ (Vilnius Gediminas Technical University, History and Theory of Arts $-03 \mathrm{H}$ ),

Prof Dr Jānis KRASTIN̦Š (Riga Technical University, History and Theory of Arts - 03H),

Assoc Prof Dr Kęstutis ZALECKIS (Kaunas University of Technology, History and Theory of Arts - 03H).

The dissertation will be defended at the public meeting of the Dissertation Defense Council of History and Theory of Arts in the Senate Hall of Vilnius Gediminas Technical University at 2 p. m. on 7 November 2013.

Address: Saulètekio al. 11, LT-10223 Vilnius, Lithuania.

Tel.: +370 5274 4956; fax +370 5270 0112; e-mail: doktor@vgtu.lt

A notification on the intended defending of the dissertation was sent on 4 October 2013.

A copy of the doctoral dissertation is available for review at the Internet website http://dspace.vgtu.lt and at the Library of Vilnius Gediminas Technical University (Sauletekio al. 14, LT-10223 Vilnius, Lithuania). 


\section{Reziumè}

Disertacijoje nagrinejjama miesto funkcinès ir kompozicinès struktūrų sąryšio problema, pasireiškianti esamų bei suplanuotų funkcijų, itraukiant galimybes susisiekti, išsidèstymo ir urbanistinès kompozicijos darna (t. y. derinimusi, neprieštaringumu) arba neatitikimu. Tiriamoji problema atskleidžiama ir nagrinèjama pasitelkiant matematinio ir grafinio modeliavimo priemones.

Śio darbo tikslas yra sudaryti miesto funkcinès ir kompozicinès struktūru sąveikos tyrimo modelį, paremtą esamų lokalių didmiesčio centrų pavyzdžių analize, ir išnagrinèti jo taikymo galimybes, nustatant veiksmingos, efektyvios urbanistinès struktūros formavimo principus. Pristatomas Vilniaus miesto lokalių centrų urbanistinès struktūros tyrimas: išsamiai išnagrinèti trys lokalūs centrai, esantys Vilniaus miesto šiaurès vakarų dalyje.

Disertaciją sudaro ịvadas, trys skyriai, rezultatu apibendrinimas, naudotos literatūros ir autoriaus publikacijų disertacijos tema sąrašai ir keturi priedai.

Ivadiniame skyriuje apibrèžiama tiriamoji problema ir jos aktualumas, aprašomas tyrimų objektas, ivvardijamas darbo tikslas ir uždaviniai, aprašoma tyrimų metodika, darbo mokslinis naujumas ir ginamieji teiginiai.

Pirmajame skyriuje, kuris yra teorinis mokslinio darbo pagrindas, nagrinèjama miesto funkcinès ir kompozicinès struktūrų samprata, hierarchinè didmiesčio centrų sistema, apžvelgiamos lokalių didmiesčio centrų urbanistinès struktūros tyrimų metodikos, atskleidžiant space syntax metodikos ypatumus ir taikymo galimybes sprendžiant apibrěžtą tiriamają problemą, nustatomi daugiafunkcių didmiesčio centrų formavimo bendrieji uždaviniai.

Antrasis skyrius - urbanistinès struktūros modeliavimui ir analizei bei tyrimo modelio sudarymui skirta disertacijos dalis. Naudojant geometrini Vilniaus miesto modeli, tiriama lokalių didmiesčio centrų urbanistinè struktūra. Nustatoma urbanistinès erdvės savybių svarba ir ịtaka lokalių centrų formavimosi procesui bei sujungiami funkciniai ir kompoziciniai urbanistinès struktūros analizės aspektai.

Trečiajame skyriuje nagrinejjamos miesto funkcinès ir kompozicinès struktūrų sąveikos tyrimo modelio naudojimo galimybès bei pateikiamos rekomendacijos, nustatant lokalių centrų urbanistinès struktūros formavimo principus, kurie taikomi rengiant urbanistinius projektus: priimant strateginius sprendimus dèl užstatymo struktūros ir viešųjų erdvių tinklo plètojimo bei nuo urbanistinio konteksto priklausančius detalius sprendimus.

Disertacijos tema paskelbti 5 straipsniai: trys - recenzuojamuose mokslo žurnaluose, vienas - recenzuojamoje užsienio tarptautinès konferencijos medžiagoje, vienas - recenzuojamoje Lietuvos konferencijos medžiagoje. Disertacijos tema perskaityti 6 pranešimai Lietuvos bei kitų šalių konferencijose. 


\section{Abstract}

The dissertation discusses the problem of coherence between functional and compositional structures of the city based on evidence that the existing and planned functions, including the possibilities of moving within the street network, and urban composition have corresponding or non-corresponding relation. The investigated problem has been revealed and analysed regarding the integration of mathematical and graphical modelling tools.

The dissertation is aimed at developing a model for investigating interdependence between functional and compositional structures of the city and is based on the analysis of the existing local centres. The thesis explores the possibilities of its application for defining formation principles of an effective urban structure. A study on three local centres situated in the north-west part of Vilnius has been carried out.

The dissertation consists of the introduction, three chapters, conclusions, a list of literature, a list of the author's publications on the subject and four annexes.

The introduction reveals the investigated problem, the importance of the thesis and the object of research as well as describes the aim and tasks of the work, research methodology, scientific novelty and defended statements.

Chapter 1 discusses a definition of functional and compositional structures and introduces a hierarchy of the centres and sub-centres of the city and reviews the methods analysing the spatial structure of local centres specifically focusing on the space syntax methodology used for finding potential solutions to the investigated problem.

Chapter 2 presents the results of modelling and analysis of urban structure used for creating an analytical model. When applying the spatial accessibility model of Vilnius city, the study focuses on the spatial structure of local centres. The task of the thesis is to investigate the importance and role of key spatial features on the formation of local centres and combine the functional and compositional aspects of the analysis of urban structure.

Chapter 3 focuses on researching the possibilities of applying the proposed model. The chapter gives recommendations for defining the principles of urban structure formation of local centres applied in urban projects: developing strategic solutions to the formation of the built-up structure and street network, investigating each component in detail and making context sensitive decisions.

5 articles focusing on the subject of the dissertation have been published: three articles - in peer-reviewed academic journals, one article - in peerreviewed proceedings of an international conference and one article - in peerreviewed proceedings of a national conference. 6 presentations on the subject have been made in conferences at national and international levels. 


\section{Sąvokos}

Aktyvios (socialinės ir ekonominės) veiklos židinys (activity node) - nuo žmoniu judèjimo priklausančiu prekybos, viešojo maitinimo ir kitų kasdienes paslaugas teikiančių imonių sankaupa.

Artimumas (closeness). Žr. integracija.

Ašinè linija. Žr. linija.

Centrinè padètis. Žr. centrality.

Didmiestis (city) - išplètotą centrų sistemą turintis miestas, regiono centras.

Dominantė arba dominuojantis elementas (dominant element) - miesto kompozicinès struktūros elementas, išsiskiriantis iš kitų elementų: 1) pastatas, pastatų kompleksas ar statinys, išsiskiriantis iš ji supančių elementų aukščiu arba tūriu (vertinant kvartalo arba kvartalu grupès lygmeniu); 2) vizualiai atskira urbanistinès erdvės dalis arba viešuju erdvių tinklo struktūros elementas, kurio apskaičiuota pasiekiamumo verte yra aukštesnè, palyginti su kitais elementais. Vertikalia dominante (vertical dominant building) vadinamas pastatas, kuris yra ne mažiau kaip du kartus aukštesnis, palyginti su esamo užstatymo foniniu aukščiu. Horizontalia dominante (horizontal dominant building) vadinamas išraiškingas pastatas, pastatų kompleksas ar statinys, kurio pagrindinis ar kitas gerai matomas fasadas išsiskiria iš esamo užstatymo.

Erdvès dalis. Žr. convex space.

Erdvès konfigūracija (spatial configuration) - vizualiai atskirų erdvès dalių (convex spaces) ir (arba) viešujų erdviụ tinklo struktūros elementų (elements of urban grid) išsidèstymo, ju tarpusavio ryšiu visuma. Moksliniame darbe vartojamas terminas urbanistinès erdvès konfigūracija, neitraukiant privačių erdvių ir pastato vidaus erdvių (domestic spaces). 
Erdvès sintaksè. Žr. space syntax.

Fonas (background) - miesto kompozicinès struktūros elementų - pastatų, pastatų kompleksu ar statinių, taip pat vizualiai atskirų urbanistinès erdvės dalių ir (arba) viešųų erdvių tinklo struktūros elementų - visuma, išskyrus dominantes.

Funkcija (function) - paskirtis, vaidmuo, veikla (Dabartinės... 2011). Šiame moksliniame darbe funkcija - pastato, pastatų komplekso ar statinio naudojimas tam tikrai veiklai bei viešujų erdvių funkcionavimas, įtraukiant galimybes susisiekti.

Funkcinè ašis (functional axis) - urbanistinèje erdvèje besidriekianti žmonių judejjimo kelio (maršruto) dalis (pvz., gatvès, pėsčiujų ar dviračių tako atkarpa). Taikant space syntax metodiką, funkcinė ašis - vienas iš viešųjų erdvių tinklo struktūros elementų (žr. linija).

Funkcinė struktūra (functional structure) - tam tikrą paskirtị (funkciją) turinčių pastatų, pastatų kompleksų ar statinių, taip pat viešujų erdvių išsidèstymo, jų tarpusavio ryšių ir funkcionavimo (pvz., žmonių judejjimo) ypatumų visuma.

Funkcinis mazgas (functional node) - žmonių susibūrimo, įvairių funkcijų susitelkimo, gatvių sankirtos ar susiliejimo vieta urbanistinejje erdvèje. Šiame moksliniame darbe nèra nagrinejjama viešojo transporto tinklo struktūra ir funkciniai mazgai, vadinamosios persedimo ị kitu maršrutu vežančią transporto priemonę arba iš vienos transporto rūšies ị kitą (pvz., iš traukinio ị autobusą) vietos - stotys ir stotelès.

Gatvių tinklas. Žr. viešujų erdvių tinklas.

Gatvių tinklo intensifikacija. Žr. viešujų erdvių tinklo intensifikacija.

Globalus lygmuo (global level) - tarpusavyje sujungtų centrų ir subcentrų (šiame moksliniame darbe - viso miesto viešujų erdvių tinklo) lygmuo.

Integracija (integration) - vienas iš urbanistinès erdvès konfigūracijos pobūdžio ịvertinimo būdų. Remiantis space syntax metodika, integracija arba matematinis artimumas (closeness) parodo, kaip arti konkreti linija yra kitų linijų atžvilgiu.

Interakcija (interaction) - dviejų ar daugiau asmenų tarpusavio sąveika, supratimas ir grịžtamasis poveikis (Tarptautinių... 2013). Moksliniame darbe vartojamas terminas socialinè interakcija, kuriuo apibrėžiamos bendravimo viešosiose erdvèse galimybės.

Judejjimas (movement) - vietos keitimas, slinkimas kuria nors kryptimi (Dabartinès... 2011). Šiame moksliniame darbe judejimas - ejjimas pèsčiomis ir važiavimas dviračiais ar automobiliais. Žmonių judejimas mieste, dar vadinamas urban movement, priklauso nuo urbanistinès erdvès konfigūracijos. Remiantis space syntax metodika natūralus judejjimas (natural movement) yra tas, kuris nepaveiktas šalutinių veiksnių. Šiame moksliniame darbe nèra nagrinejjamas žmonių judejjimas viešuoju transportu, kuris priklauso nuo maršrutų tinklo ypatumų ir funkcinių mazgų išsidèstymo. Taip pat žr. tomovement ir through-movement.

Jungiamumas (connectivity) - gatvių ir kitų viešujuc erdvių tinklo ypatybè, lokalių centrų ir jų urbanistinio konteksto - gretimų gyvenamųjų kvartalų - ryšių visuma (taip pat ir tam tikrą paskirti (funkciją) turinčių užstatymo struktūros elementų, atsižvelgiant ị viešujų erdvių tinklo ypatumus).

Kelias arba maršrutas (path; route) - tarpusavyje sujungtų linijų (gatvės atkarpų) seka, trumpiausias maršrutas (įvertinant mažiausią posūkio kampą (least angle), t. y. apskaičiuotą kampo tarp dviejų gretimų ir tarpusavyje sujungtų linijų didumą) tarp bet kurių dviejų linijų (gatvès atkarpų) nagrinèjamame tinkle.

Kompozicija (composition). Žr. urbanistinè kompozicija. 
Kompozicinė ašis (compositional axis) - urbanistineje erdvejje besidriekianti vizualinè ašis ar jos dalis, abipus kurios išsidèstę užstatymo struktūros elementai. Globaliu lygmeniu - vienas iš lokalius centrus jungiančių viešujų erdvių tinklo struktūros elementų.

Kompozicinè struktūra (compositional structure) - tam tikrą meninị ir vizualinị potencialą turinčiu pastatų, pastatụ kompleksu ar statinių, taip pat vizualiai atskirų urbanistinės erdvės dalių ir (arba) viešujų erdvių tinklo struktūros elementų išsidėstymo, jų tarpusavio ryšiu visuma. Globaliu lygmeniu - lokaliu centrų ir juos jungiančiu viešujų erdvių tinklo struktūros elementų išsidèstymo, jų tarpusavio ryšių visuma.

Kompozicinis mazgas (compositional node) - kompozicinių ašiu sankirtos taškas. Globaliu lygmeniu - vienas iš didmiesčio, atskirų jo dalių (pvz., gyvenamuju rajonų) centrų. Šiame moksliniame darbe svarbiais kompoziciniais mazgais laikomi vadinamieji vartai $i$ lokalų centrą (gateways to the local centre) ir gatviu sankirtos, iš kurių matoma vertikali ar horizontali dominantè.

Konversija (conversion) - miesto dalies, kvartalo arba kvartalu grupés naudojimo paskirties (funkcijos) keitimas: pramonès, sandèliụ, garažu, komunaliniu ịmoniu ir kitu neefektyviai naudojamų (paprastai užstatytụ ir (arba) apleistų) teritorijų naujas (antrinis) panaudojimas plètrai, t. y. pertvarkymas ị komercinès, gyvenamosios, visuomeninès ir mišrios paskirties kvartalus.

Kvartalas (block) - urbanistinès struktūros elementas, ribojamas gatvių ir kitų viešųuц erdvių bei gamtinių elementų (kurie gali būti natūralios kliūtys), pvz., parkų, skverų, žaliụjų jungčių ir kitų želdynų, upių ir vandens telkinių.

Linija (line, axial line, segment) - viešujų erdvių tinklo struktūros elementas - linija, ašinè linija arba linijinis elementas (linear element) - gatvès atkarpa tarp sankryžųu, pèsčiuju takas, alëja ir kt. Taikant space syntax metodiką, ašinès linijos - nagrinejjamos teritorijos viešąsias erdves kertančios vizualinès (arba netrukdomo judejjimo) ašys brěžiamos ranka miesto topografiniame plane, arba automatiniu būdu gaunami linijiniai elementai, supaprastinus georeferencinio pagrindo duomenų bazès ašines gatviu linijas (road centre lines). Susikertančių linijų (matematinių abstrakcijų) modelis naudojamas apskaičiuojant viešujų erdvių pasiekiamumo vertes (spatial accessibility values).

Lokalus lygmuo (local level) - kvartalų ir juos jungiančių viešujų erdvių (šiame moksliniame darbe - lokalų centrą sudarančių viešųų erdvių) lygmuo.

Miesto planas arba pastatų, pastatų kompleksų ar statinių ir viešujų erdvių tinklo planas (urban layout) - užstatymo struktūros elementụ ir gatvių bei kitų viešujų erdvių tinklo elementu išsidèstymas. Anglụ kalbos terminas spatial layout vartojamas kalbant apie urbanistinès erdvès - ribotos trijų matmenų tuštumos - elementų ir erdvinį užstatymo struktūros elementų išsidèstymą.

Miesto plano kompozicija. Žr. urbanistinè kompozicija.

Nominali erdvè. Žr. convex space.

Pasiekiamumas (accessibility) - patogumas pasiekti tam tikrą vietą, kuris gali būti apibūdinamas vertinant pessčiujų bei automobilių transporto judejjimą, atstumą pėsčiomis iki viešojo transporto stoteliu ir būtiniausių paslaugų, kelionès laiką arba gyventojų pasiskirstymą tam tikroje teritorijoje (Cowan 2005). Space syntax nuo kitu metodikų skiriasi tuo, kad pasiekiamumas matuojamas naudojant geometrini gatvių modeli ir vertinant mažiausio posūkio kampo (least angle) tarp dviejų gatvès atkarpų reikšmes.

Pasirinkimas (choice) - vienas iš urbanistinès erdvès konfigūracijos pobūdžio įvertinimo būdụ. Remiantis space syntax metodika, pasirinkimas arba matematinis pereina- 
mumas (betweenness) parodo, kiek trumpiausių maršrutų driekiasi konkrečia linija tarp kitų dviejų linijų nagrinèjamame modelyje.

Pereinamumas (betweenness). Žr. pasirinkimas.

Pralaidumas arba gatvių tinklo „susisiekiamumas“ (permeability) - galimybes susisiekti užtikrinanti gatvių ir kitų viešuju erdvių tinklo ypatybè, susijusi su kvartalų dydžiu ir išsidėstymu. Kuo aukštesnis pralaidumo rodiklis, tuo daugiau galimybių pereiti, kirsti miestą ar jo dalị pasirenkant ịvairius maršrutus.

Saitas (link) - ryšys tarp dviejų besiribojančių (susisiekiančių) vizualiai atskirų urbanistinès erdvès daliụ arba dviejų gretimų ir tarpusavyje sujungtų linijų (gatvės atkarpu)). Kaip priešprieša miestų inžinerijos srityje taikomiems gatvių tinklo struktūros analizès metodams, kur liniju sankirtos taškai yra mazgai, o gatvės atkarpos yra saitai, remiantis space syntax metodika saitai yra liniju sankirtos. Nagrinejant viešojo transporto tinklo struktūrą saitu vadinamas ryšys tarp dviejų gretimų ir tarpusavyje sujungtų maršruto atkarpu, kurios driekiasi nuo vieno iki kito funkcinio mazgo.

Socialinė interakcija (social interaction). Žr. interakcija.

Struktūra (structure) - daikto daliu tarpusavio išsidèstymas ir ryšys, sandara; objekto arba reiškinių sistemos sandara, atsieta nuo jų kilmès, funkcijų, elementų, požymių (Tarptautinių... 2013). Moksliniame darbe struktūra apibrěžiama kaip elementų išsidèstymo ir jų tarpusavio ryšių visuma.

Susisiekimas (connection) - judejjimas iš vienos vietos ị kitą (Dabartinès... 2011). Šiame moksliniame darbe susisiekimas - judejjimas iš vienoje gatvès atkarpoje (linijoje) esančios išvykimo vietos - kelionés pradžios (origin) - i kitoje gatvės atkarpoje (linijoje) esančią paskirties vietą - kelionès tikslą (destination).

Susisiekiamumas. Žr. pralaidumas.

Teritorijos ir (arba) pastato paskirtis (land use) - teritorijos ir (arba) pastato, pastatu komplekso ar statinio funkcija, naudojimas tam tikrai veiklai.

Traukos objektas (attractor) - kasdienius gyventoju poreikius tenkinanti prekybos ir paslaugų įmonė ar jų sankaupa - parduotuvè, prekybos centras, prekybos ir pramogų kompleksas etc. Globaliu lygmeniu - lokalus centras.

Traukos zona (catchment area) - teritorija, kurioje gyvenantys ar dirbantys žmonès gali patogiai pasiekti vietą, kurioje teikiamos būtiniausios paslaugos, arba traukos objektą (attractor). Moksliniame darbe traukos zona nustatoma vertinant atstumą (kai kelionės maršrutas priklauso nuo geometrinio gatvių modelio ypatumų) iki lokalaus centro (paprastai $800 \mathrm{~m}$ nuo kraštinių namų). Taip pat gali būti nustatoma vertinant kelionès laiką einant pesčiomis (pvz., $800 \mathrm{~m}$ nueinama per $10 \mathrm{~min}$.), važiuojant automobiliu ar viešuoju transportu.

Urbanistinė erdvė (urban space) - užstatymo struktūros elementụ ir gamtinių elementų (reljefo ir želdynų) ribojama trijų matmenu tuštuma, patenkanti į žmogaus regejjimo lauka (Alistratovaitè 2004). Urbanistinè erdvè gali būti skaidoma ì vizualiai atskiras erdvès dalis (žr. convex space). Taikant space syntax metodiką, urbanistinès erdvès elementų išsidèstymo plane, jų tarpusavio ryšių visumai nagrinèti naudojamas geometrinis linijinių elementų modelis.

Urbanistinė kompozicija (urban composition) - miesto kompozicinès struktūros elementu išsidèstymas, ju tarpusavio ryšys ir santykis su visuma. Anksčiau Lietuvos tyrejju darbuose plačiai vartota miesto tūrinès erdvinès kompozicijos sąvoka (Jurkštas 1975; 1977). 
Urbanistinė struktūra (urban structure) - miesto funkcinės ir kompozicinės struktūrų elementų išsidėstymo, jų tarpusavio ryšių ir funkcionavimo ypatumų visuma.

Urbanistinis kompleksas (urban complex) - tarpusavyje susijusių, dažniausiai vienos paskirties (gali būti ir mišrios paskirties) pastatu grupè.

Urbanistinis projektas (urban design project) - projektas, kuriame numatomi svarbiausi pastatų, pastatų kompleksų ar statinių architektūriniai ir urbanistiniai sprendimai (dažniausiai nesprendžiant pastatų vidaus erdvių formavimo klausimų) bei juos supančių viešuju erdvių formavimo sprendimai. Paprastai rengiami kvartalų (kvartalų grupès), stambių urbanistinių kompleksų bei juos ribojančiu gatvių ir kitų viešujų erdvių suplanavimo projektai. Taip pat gali būti rengiami esamų miestų ar jų dalių pertvarkymo ir naujų miestų projektai.

Užstatymo aukštis (height of building blocks) - vyraujantis (daugiau kaip 70 procentu užstatymo) miesto, jo dalies ar kvartalo pastatų aukštų skaičius arba didžiausias galimas pastatų aukštis metrais.

Užstatymo foninis aukštis (height of background buildings) - vidutinis esamas ar planuojamas miesto, jo dalies ar kvartalo užstatymo aukštis.

Užstatymo morfologinis tipas (type of building blocks based on their architectural and urban morphology) - miestui, jo daliai ar kvartalui būdinga užstatymo struktūros formavimo(si) principų visuma.

Užstatymo struktūra (built-up structure) - pastatų, pastatų kompleksų ar statinių išsidèstymo, jų tarpusavio ryšiu visuma.

Viešųjų erdvių pasiekiamumo modelis (spatial accessibility model) naudojamas apskaičiuojant viešujų erdvių pasiekiamumo vertes (spatial accessibility values). Modelis yra kuriamas miesto topografiniame plane brěžiant ašines linijas - nagrinejjamos teritorijos viešąsias erdves kertančias vizualines (arba netrukdomo judèjimo) ašis. Vietoje ašiniụ linijų plano (axial map) gali būti naudojamas linijinių elementų (gatvès atkarpų tarp sankryžu) planas (segment map), kuris sudaromas automatiniu būdu, supaprastinus georeferencinio pagrindo duomenų bazės ašines gatviụ linijas (Turner 2007). Naudojant iš vizualines ašis žyminčiu linijų sudarytą modeli (axial model) arba supaprastintu ašinių gatvių linijų modeli (centre-line model) paprastai yra taikomas mažiausio posūkio kampo (least angle) linijinių elementų analizès (segment angular analysis) kriterijus (Hillier 2009).

Viešųjų erdvių tinklas (urban grid) - gatvès, pėsčiujų takai, alèjos, aikštès, parkai, skverai ir kitos viešosios erdvès, kurios yra tarpusavyje sujungtos ir sudaro sistemą. Remiantis space syntax metodika, viešujų erdvių tinklą sudaro linijos arba linijiniai elementai (pvz., gatvès atkarpos tarp sankryžų), tarpusavyje susieti saitais. Nagrinejjant iš tarpusavyje sujungtu pagrindiniu viešujų erdviụ tinklo elementų, naudojamų susisiekti pesčiomis, važiuoti dviračiais ir (arba) automobiliais, sudarytą sistemą, vartojama gatvių tinklo (street network) sąvoka.

Viešųju erdvių tinklo intensifikacija (urban grid intensification) - gatvių (pėsčiujų taku, alèju, aikščiu, parku, skveru ir kitụ viešuju erdvių) tinklo tankinimas, pralaidumo (gatvių tinklo „susisiekiamumo") didinimas siekiant sumažinti vidutinị atstumą tarp bet kurių dviejų gatvių atkarpų (linijų) nagrinèjamame tinkle.

Vieta (place) - erdvès dalis, kurioje galima būti, ka daryti, kurioje kas yra, vyksta (Dabartinès... 2011). Šiame moksliniame darbe vieta urbanistineje erdveje - vizualiai atskira urbanistinès erdvès dalis (žr. convex space) arba jų grupè, iš kurių bent vieną kerta ašinė linija. 
Vizualiai atskira urbanistinès erdvès dalis. Žr. convex space.

Vizualinè ašis (visual axis) - urbanistinejje erdvèje besidriekianti ašinè linija. Taikant space syntax metodiką, vizualinès ašys paprastai brèžiamos miesto topografiniame plane (žr. linija). Vizualinė ašis gali būti apibrèžiama kaip sankryžoje (arba gatvès posūkyje) stovinčio žmogaus regejjimo lauko dalis, atitinkanti gatvėvaizdžio stebejjimo kryptị (line of sight).

Vizualinè erdvè. Žr. convex space.

Vizualinis ryšys (visual connection). Žr. vizualinė ašis.

\section{Anglų kalbos terminai}

Centrality (centrinè padètis) - matematiniais skaičiavimais pagrịsta viešujų erdvių tinklo struktūros elementų santykinè svarba nagrinejjamame tinkle. Globaliu lygmeniu - lokalių centrų santykinė svarba kitų miesto dalių atžvilgiu. Taikant space syntax metodiką, gatvės atkarpos vietai ir vaidmeniui viešujų erdvių tinkle nustatyti naudojamas geometrinis linijinių elementų modelis.

Convex space (vizualiai atskira urbanistinès erdvès dalis) - tiesiogiai ir vientisai suvokiama (t. y. vienu žvilgsniu aprèpiama), lengvai suprantama vieta urbanistinejje erdvèje aikštė, gatvès erdvès dalis arba kita viešoji erdvė, kurioje kiekvienas taškas yra matomas iš visų kitų joje esančių taškų (kalbant matematiniais terminais, tam tikra erdvės dalis yra iškila (convex), jeigu per bet kuri erdvès dalị ribojančio perimetro tašką gali būti nubrèžta liestinè, nekertanti pačios erdvès dalies). Kai kurie autoriai vartoja vizualinès erdvès (Purvinas 1983) ir nominalios erdvės (Jurkštas 1994) sąvokas, kurios yra artimos, bet netapačios. Moksliniame darbe erdvès dalis apibrèžiama kaip ,vizualiai atskira“, jeigu joje yra taškų, iš kurių negalima matyti visų kitų gretimoje erdvès dalyje esančių taškų.

Space syntax (erdvès sintaksè) - miesto viešujų erdvių tyrimo metodika, taikoma architektūros, urbanistinio projektavimo ir planavimo veikloje. Metodika paremta urbanistinès erdvès sandaros ir jos elementų tarpusavio ryšių geometriniu vaizdavimu ir ja siekiama atskleisti erdvès savybių ir socialinių bei ekonominių procesų mieste sąveiką. Šios metodikos teorinis pagrindas - fundamentalieji ir taikomieji erdvès sandaros ir žmoniu judejjimo pobūdžio (pattern of movement) priklausomybès nuo urbanistinès erdvès konfigūracijos (spatial configuration) tyrimai, kurie yra paremti judejjimo ekonomikos (movement economy) modeliu ir kurie nuo XX a. 8-ojo dešimtmečio pabaigos plètojami Billo Hillier ir kitų Londono universiteto koledžo (University College London) mokslininkų.

Through-movement (vizualiai atskiros urbanistinès erdvès dalies perèjimas, pervažiavimas) - judejjimas pėsčiomis ar automobiliu tam tikra gatvės atkarpa (linija), kai objektas (kelionès tikslas) yra kitoje gatvès atkarpoje (linijoje).

To-movement (nuejjimas, nuvažiavimas ị vizualiai atskirą urbanistinès erdvès dali) judejjimas pėsčiomis ar automobiliu ị tam tikroje gatvès atkarpoje (linijoje) esantị objektą (kelionès tikslą).

Pastaba: anglų kalbos terminai centrality, convex space, through-movement, tomovement neturi tikslių atitikmenų lietuvių kalboje (pateikiami autoriaus siūlomi lietuviški atitikmenys). Šiame moksliniame darbe terminas space syntax (lietuviškas atitikmuo - erdvès sintaksė) neverčiamas ị lietuvių kalbą, kai kalbama apie viešųų erdvių tyrimo metodiką. 


\section{Žymëjimai}

\section{Simboliai}

CH arba choice - pasirinkimo - urbanistinès erdvès konfigūracijos pobūdžio ivertinimo simbolis;

Depthmap_Ref-linijos (viešosios erdvès) numeris;

$\log _{\text {C }} \mathrm{CH}$ - linijos (viešosios erdvès) pasiekiamumo vertè, apskaičiuota taikant neapibrèžtą spinduli;

log_CH_R800_m - linijos (viešosios erdvès) pasiekiamumo vertè, apskaičiuota taikant aštuonių šimtų metrų spindulị;

log_CH_R2000_m-linijos (viešosios erdvès) pasiekiamumo vertė, apskaičiuota taikant dviejų tūkstančių metrų spindulį;

$U C$ arba urban composition - urbanistinès kompozicijos įvertinimo simbolis.

\section{Santrumpos}
a. - amžius;
lot. - lotynu kalba;
DB - duomenų bazé;
pan. - panašiai;
etc. - lot. et cetera ,ir kita, ir taip toliau“;
pav. - paveikslas;
GIS - geografinè informacinè sistema;
pvz. - pavyzdžiui, pavyzdys;
JAV - Jungtinès Amerikos Valstijos;
t. y. - tai yra;
JK - Jungtinè Karalysté;
žr. - žiūrèk.
kt. - kiti, kitkas; 



\section{Turinys}

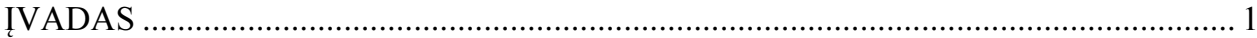

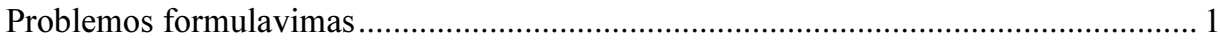

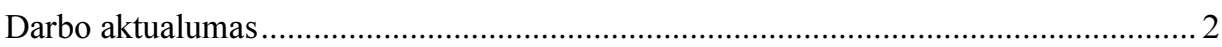

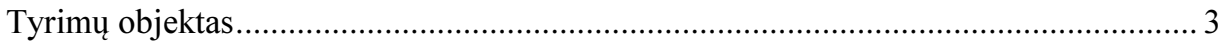

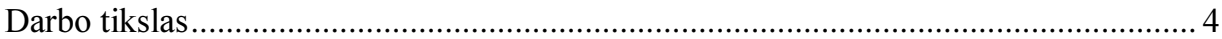

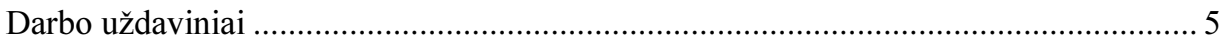

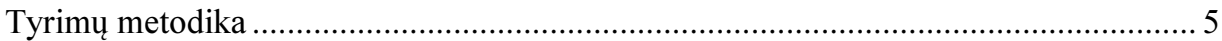

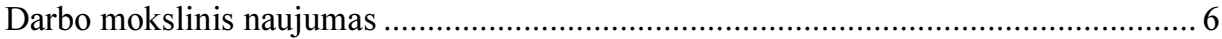

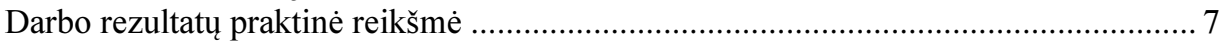

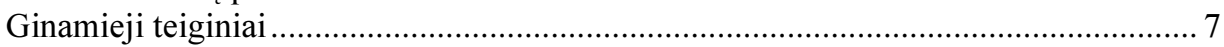

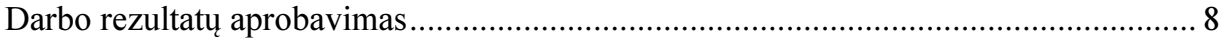

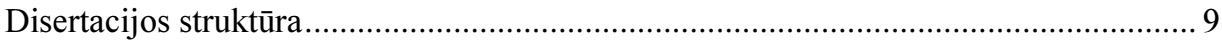

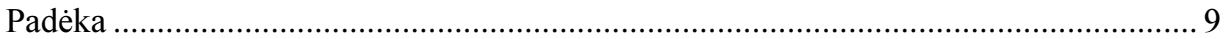

1. MIESTO FUNKCINĖS IR KOMPOZICINĖS STRUKTŪRŲ TYRIMŲ

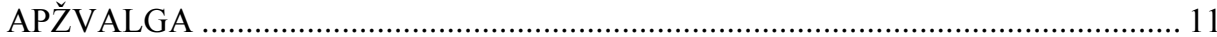

1.1. Miesto funkcinès ir kompozicinès struktūrų samprata .......................................... 11

1.2. Lokalių didmiesčio centrų ypatumai ..................................................................... 16

1.2.1. Hierarchinè didmiesčio centrų sistema. Daugiafunkcių didmiesčio centrų formavimo bendrieji uždaviniai............................................................. 17

1.2.2. Lietuvos didmiesčių lokalių centrų plètojimo galimybès ............................. 19

1.3. Lokalių didmiesčio centrų urbanistinès struktūros tyrimų metodika....................... 22 


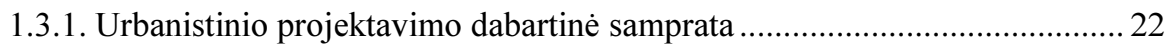

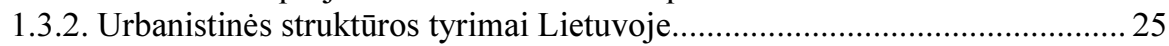

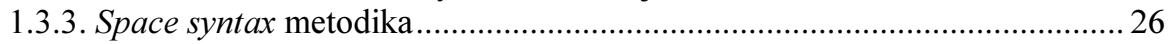

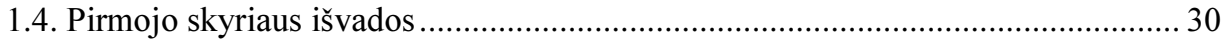

2. LOKALIỤ DIDMIESČIO CENTRỤ URBANISTINĖS STRUKTŪROS TYRIMAI. 33

2.1. Lokalių centrų vieta ir vaidmuo hierarchineje didmiesčio centrų sistemoje........... 33

2.2. Funkcinių ir kompozicinių urbanistinès struktūros analizės aspektų sujungimas.. 43

2.2.1. Funkcinès struktūros tyrimas .................................................................... 48

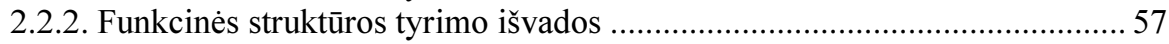

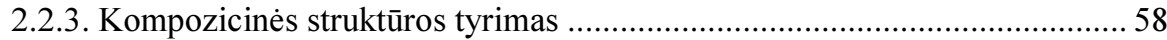

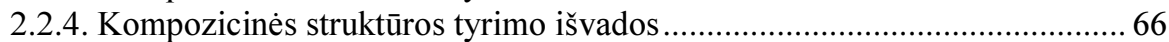

2.3. Funkcinès ir kompozicinès struktūrų sąveikos tyrimo duomenų mokslinè

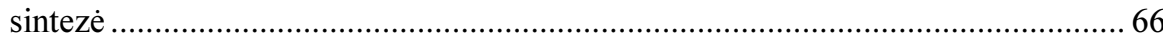

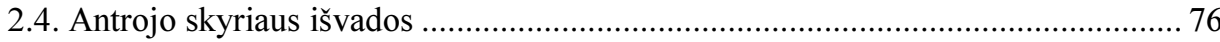

3. LOKALIŲ CENTRŲ URBANISTINĖS STRUKTŪROS FORMAVIMO

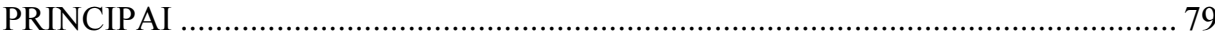

3.1. Lokalių centrų tyrimo ir gautų rezultatų santykis su kitų tyrèjų rezultatais........... 80

3.2. Lokalių centrų urbanistinès struktūros formavimo principų nustatymas ................83 83

3.3. Bendrai priimtini plètros principai ir sprendimų prièmimas..................................8 87

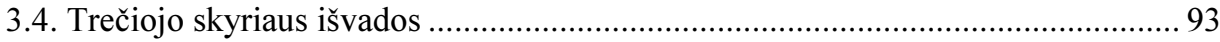

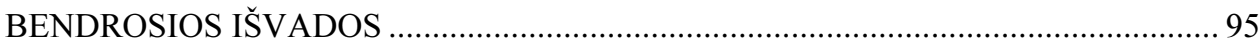

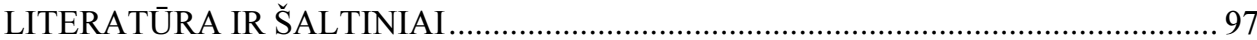

AUTORIAUS MOKSLINIŲ PUBLIKACIJŲ DISERTACIJOS TEMA SĄRAŠAS .... 107

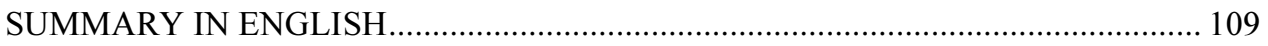

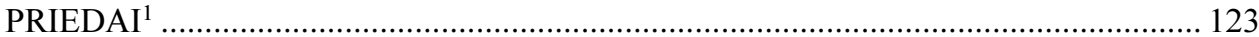

A priedas. Vilniaus miesto viešujų erdvių pasiekiamumo schemos .......................... 124

B priedas. Šeškinès, Fabijoniškių ir Pašilaičių lokalius centrus sudarančių viešujų

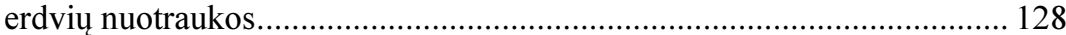

C priedas. Šeškinès, Fabijoniškių ir Pašilaičių lokalių centrų funkcinės ir

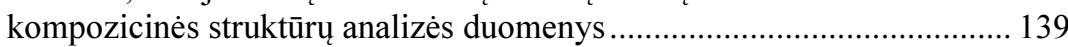

D priedas. Autoriaus mokslinių publikacijų disertacijos tema kopijos........................ 160

${ }^{1}$ Priedai pateikiami pridètoje kompaktinèje plokštelèje. 


\section{Contents}

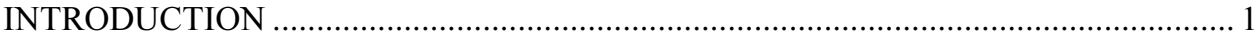

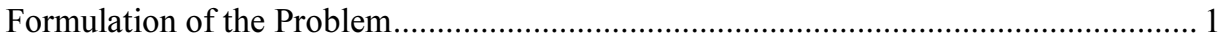

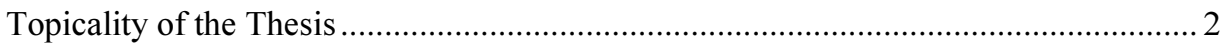

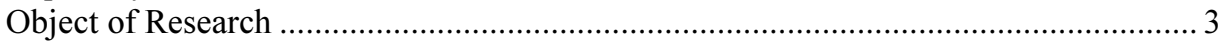

Aim of the Work

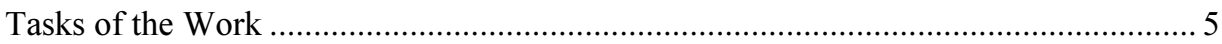

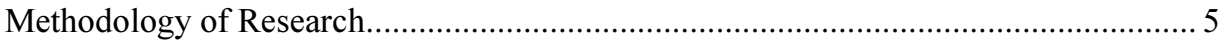

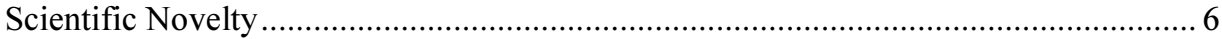

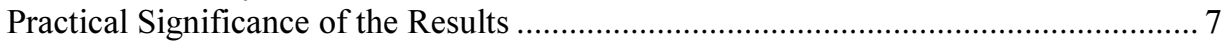

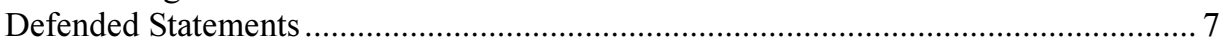

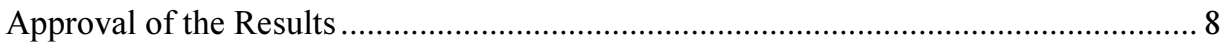

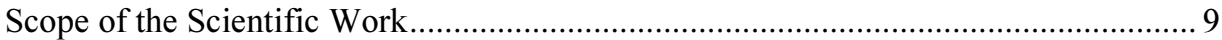

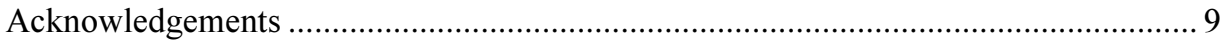

1. THEORETICAL BACKGROUND FOR INVESTIGATING FUNCTIONAL AND COMPOSITIONAL STRUCTURES OF THE CITY ……......................................... 11

1.1. Understanding Functional and Compositional Structures of the City..................... 11

1.2. Definitions of the Main Features of Local Centres ................................................ 16

1.2.1. Hierarchical System of City Centres. Common Objectives of the Formation of Mixed-Use City Centres ...................................................... 17

1.2.2. Possibilities of Developing Local Centres in Lithuanian Cities .................. 19

1.3. Methodological Approach to Studying the Urban Structure of Local Centres ...... 22 
1.3.1. Commonly Accepted Definition of Urban Design ................................... 22

1.3.2. Research on Urban Structure in Lithuania................................................. 25

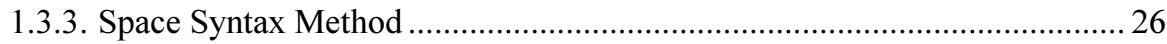

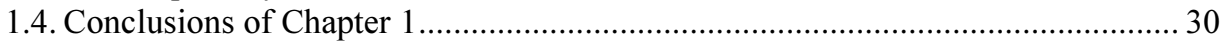

\section{INVESTIGATION INTO URBAN STRUCTURE IN THE LOCAL CENTRES OF}

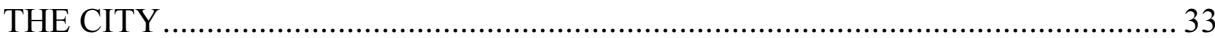

2.1. Location and Role of Local Centres in the Hierarchical System of City Centres.. 33

2.2. Combining Functional and Compositional Aspects of the Analysis of Urban

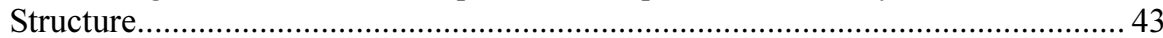

2.2.1. Analysis of Functional Structure ........................................................ 48

2.2.2. Conclusions of the Analysis of Functional Structure .............................. 57

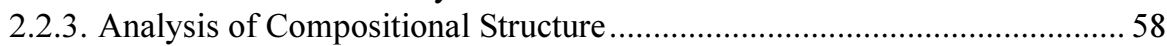

2.2.4. Conclusions of the Analysis of Compositional Structure .......................... 66

2.3. Synthesis of Findings from the Case Study on Interdependence Between

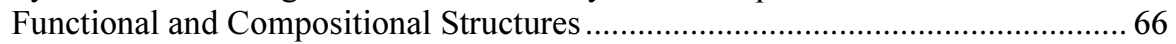

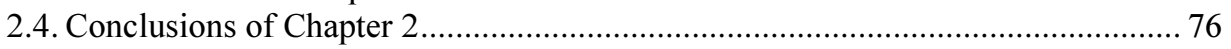

3. PRINCIPLES OF URBAN STRUCTURE FORMATION IN THE LOCAL CENTRES OF THE CITY

3.1. Relationship Between Results Achieved by Studying Local Centres and

Findings Presented by Other Researchers

3.2. Defining Principles of Urban Structure Formation in the Local Centres of the City

3.3. Commonly Accepted Principles of Development and Decision-Making Process . 87

3.4. Conclusions of Chapter 3 ...................................................................... 93

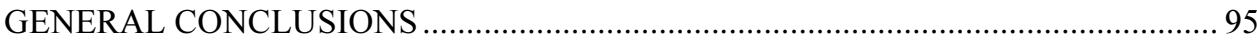

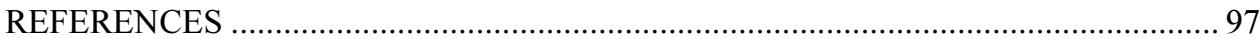

LIST OF PUBLISHED SCIENTIFIC WORKS ON THE TOPIC OF THE

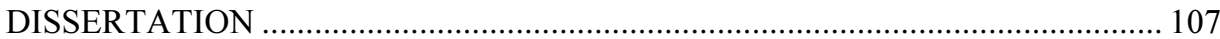

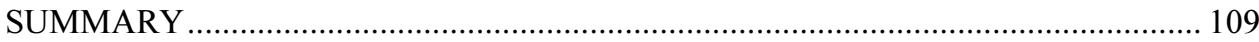

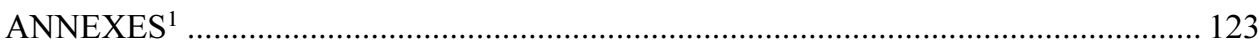

Annex A. Spatial Accessibility Models of Vilnius City ......................................... 124

Annex B. Pictures of Public Spaces of Local Centres in Šeškinè, Fabijoniškès

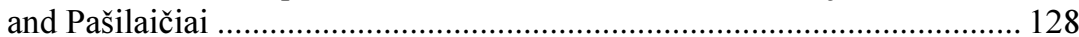

Annex C. Data on the Analysis of Functional and Compositional Structures in the Local Centres Situated in Šeškinè, Fabijoniškès and Pašilaičiai .......... 139

Annex D. Copies of Scientific Publications on the Topic of the Dissertation............ 160

${ }^{1}$ The annexes are supplied in the enclosed compact disc. 


\section{Ivadas}

\section{Problemos formulavimas}

Miesto kaip funkcinès ir erdvinès visumos ${ }^{1}$ samprata yra vienas iš urbanistikos mokslo ir kūrybos kertinių akmenų, kuriuo remiantis priimami urbanistinès struktūros formavimo sprendimai. Nagrinejjant atskirus miesto struktūros elementus ir ieškant jų tarpusavio ryšių, arba siekiant sujungti geriausius pavienių elementų komponavimo sprendimus yra sunku gauti visaverčius rezultatus, nes miestas kaip visuma turi tokių savybių, kurios yra nebūdingos jo elementams. Nuo urbanistinès struktūros funkcinių ir erdvinių savybių visumos priklauso miesto funkcionavimo kokybė. Miesto funkcinès ir kompozicinès struktūrų sąveika pasireiškia per šių struktūrų elementų išsidèstymą, tarpusavio ryšius ir tarpusavio priklausomybę.

Disertacijoje nagrinejama miesto funkcinès ir kompozicinès struktūrų sąryšio problema, pasireiškianti esamų bei suplanuotų funkcijų, itraukiant galimybes susisiekti, išsidèstymo ir urbanistinès kompozicijos darna (t. y. derinimusi, neprieštaringumu) arba neatitikimu. Naujiems moksliniams rezultatams

\footnotetext{
${ }^{1}$ Šiame moksliniame darbe remiamasi sisteminiu požiūriu ị urbanistinę struktūrą ir jos funkcionavimą. Struktūros sąvoka atskleidžiama remiantis visumos (sistemiškumo) principu ir transformacijos idèja (Gumauskaitè 2000).
} 
gauti pasirinkti aiškiai apibrèžti tyrimo metodai, kurie taikomi nagrinejjant aktualius pavyzdžius. Iškeltą problemą siekiama spręsti sujungiant tikslių kiekybinių tyrimo metodų galimybes, tyrimu objektu įvardijant svarbius didmiesčių struktūros elementus - lokalius centrus. Tiriamoji problema atskleidžiama ir nagrinejjama pasitelkiant matematinio ir grafinio modeliavimo priemones.

\section{Darbo aktualumas}

Lietuvoje dèl tinkamai neapibrèžtu urbanistinio projektavimo ir planavimo strateginių gairių, kurių vienas iš tikslų yra paaiškinti funkcinius ir kompozicinius urbanistinès struktūros formavimo aspektus ir jų derinimą, susiduriama su sunkumais nustatant esamos urbanistinès struktūros, ypač miestų centrinių dalių, nutolusių gyvenamujų rajonų ir prie pagrindinių gatvių esančių kvartalų, kurie suplanuoti taikant funkcinio zonavimo principus, pertvarkymo ir naujujų dalių formavimo prioritetus. Funkcinių ir kompoziciniu miesto plètros aspektų derinimo problemai urbanistinio projektavimo ir planavimo praktineje veikloje skiriama mažai dėmesio. Rengiant urbanistinès plètros koncepcijas ir kitus planavimo dokumentus pirmenybè teikiama funkciniams klausimams spręsti ${ }^{2}$. Funkciniai ir kompoziciniai miesto plètros aspektai dažniausiai yra nagrinejjami atskirai, todèl tolesnis miesto funkcinès ir kompozicinès struktūrų sampratos tikslinimas, ieškant bendrų sąlyčio taškų ir siekiant nustatyti minètų aspektų sujungimo būdus, yra aktuali urbanistikos problema.

Susisiekimo $^{3}$ arba žmonių judejjimo mieste problema yra viena iš svarbiausių, vertinant miestą kaip visumą funkciniu aspektu. Galimybė iš bet kurios miesto vietos patogiai pasiekti kasdienius gyventojų poreikius tenkinančias prekybos ir paslaugu imones, darbo ir mokymo įstaigas bei laisvalaikio leidimo vietas yra neabejotinas gyvenimo mieste privalumas. Lokalių centrų stiprinimo ir gatvių tinklo plètros, sudarant sąlygas susisiekti pèsčiomis bei naudotis įvairių rūšių transportu, uždavinių derinimas sprendžiant veiksmingos, efektyvios urbanistinès struktūros formavimo klausimus yra viena iš pagrindinių darnios plètros užtikrinimo priemonių. Minètiems klausimams užsienio mokslininkai skiria

\footnotetext{
${ }^{2}$ Reikia paminèti ir kitą per daug supaprastintą požiūrị - gatvių išdèstymo planų rengimą ir tvirtinimą, išvengiant sudètingų urbanistinès struktūros ir jos funkcionavimo klausimų. Tokio planavimo svarbiausiomis sąlygomis tampa savaime suprantamas gatvès nedalijamumas (gatvę skaidančių objektų nebuvimas) ir privažiavimas (užtikrintos susisiekimo galimybès), bet ne efektyvaus, veiksmingo gatvių tinklo užtikrinimas. 3 Šiame moksliniame darbe dèmesys yra sutelkiamas ị žmonių judèjimą mieste, priklausantị nuo urbanistinès erdvès konfigūracijos, ir nèra nagrinėjamos susisiekimo (communication) naudojantis ryšių priemonėmis galimybès.
} 
daug dèmesio, tačiau Lietuvoje trūksta mokslinių darbų, kuriuose būtų nagrinejjamas gatvių tinklo formavimo(si) ir žmogaus veiklos mieste ypatumų tarpusavio ryšys, keliant Lietuvos didmiesčių problemas ir siūlant jų sprendimo būdus.

Kompozicinès struktūros formavimas yra paremtas miesto, jo dalies ar kvartalų ir juos jungiančių viešujų erdvių meninio ir vizualinio potencialo atskleidimu, išryškinimu bei stiprinimu. Problema yra ta, kad neįvertinus formuojamos ar pertvarkomos struktūros, ypač naujų urbanistinių elementų poveikio socialinei ir ekonominei veiklai, kai igyvendinti sprendimai ne tik lemia pokyčius kvartalu lygmeniu, bet ir turi itakos viso miesto mastu, palaipsniui gali išryškèti dèl neefektyvaus funkcionavimo kylančios problemos. Tai parodo poreikị bendradarbiauti specialistams, atsakingiems už tam tikrus urbanistinio projektavimo ir planavimo aspektus. Kitas svarbus veiksnys - naudojimasis informaciniu technologijų teikiamomis galimybemis siekiant priimti ir pagrịsti urbanistinio projektavimo sprendimus, pasitelkiant aukščiausio lygio mokslo centruose dirbančių mokslininkų plètojamą urbanistinès erdvès analizės programinę įrangą; tai leidžia susidaryti kiek įmanoma objektyvesnį minètų kompozicinès struktūros formavimo problemų vaizdą, pažvelgti ị jas iš šalies bei ịvertinti urbanistinio projektavimo sprendimus ir jų igyvendinimo prioritetus.

\section{Tyrimu objektas}

Tyrimų objektas - lokalių didmiesčio centrų funkcinès ir kompozicinės struktūrų sąryšio ypatumai, kurie yra nagrinejjami naudojant urbanistinès erdvès struktūros geometrinius modelius. Nagrinejjami būdingi Vilniaus miesto pavyzdžiai: planuojant tyrimus susitelkta ị probleminemis ịvardijamas miesto dalis, sovietiniais metais suformuotus gyvenamuosius rajonus. Rengiant minètų gyvenamujų rajonų centrų urbanistinius projektus taikyti funkcinio zonavimo, pèsčiujų ir automobilių srautu atskyrimo ir kiti modernistinio (laisvojo) planavimo sprendimai bei neužtikrintas lokalių centrų tarpusavio jungiamumas šiame moksliniame darbe yra priskiriami veiksniams, kurie yra svarbūs atskleidžiant dèl miesto plano neužbaigtumo ir (arba) neefektyvumo kylančius prieštaringumus.

Didmiesčiui yra būdinga skirtingų centrų tipų įvairovè. Hierarchinę didmiesčio centrų sistemą sudaro pagrindinis (istorinis) miesto centras ir antriniai miesto dalių bei lokalūs gyvenamuju rajonų centrai. Moksliniame darbe remiamasi požiūriu i mieste vykstančius socialinius ir ekonominius procesus, didmiesčio centrų hierarchiją tiesiogiai susiejančiu su viešujų erdvių - gatvių, aikščių, alëjų ir kt. - naudojimu susisiekti. 
Dauguma sovietinių metư ${ }^{4}$ statybos Lietuvos didmiesčių gyvenamujjų rajonų centrų buvo suformuoti atskiriant automobilių ir pėsčiųų srautus bei ignoruojant istorinę gatvių paskirti, sujungiančią susisiekimo ir bendravimo funkcijas. Tokiu formavimo prioritetu pasirinkimas buvo paremtas Clarence'o Perry (1929) pasiūlytais planavimo principais ir jais pagrịstomis lokalių centrų ir juos supančių kvartalų koncepcinèmis schemomis, sukuriant susisiekimo ir socialinès interakcijos viešosiose erdvėse galimybes apribojančias kvartalu grupes, kurios paprastai išdèstytos taip, kad jų nebūtų galima kirsti vykstant iš vienos miesto dalies ị kitą.

Nuo 1990 m. Lietuvos didmiesčių lokalių centrų plètra nebuvo reguliuojama. Prekybos ir paslaugų objektų ${ }^{5}$ susitelkimui tam tikrose miesto dalyse didelès įtakos turejo šie veiksniai: galimybès vykdyti komercinę veiklą sovietiniais metais suformuotuose vadinamuosiuose visuomeniniuose centruose, pritaikant esamus pastatus naujoms funkcijoms, ir plètoti pavienių komercinès paskirties objektų ir stambių prekybos bei pramogų kompleksų projektus neužstatytuose sklypuose, esančiuose verslo požiūriu patraukliose vietose, pavyzdžiui, Ukmergès ir Ozo gatvėse Vilniuje. Nuo urbanistinès erdvès konfigūracijos ir žmonių judejjimo intensyvumo priklausančių plètros galimybiu (potencialo) analizei nebuvo skiriama pakankamai dèmesio.

\section{Darbo tikslas}

Šio darbo tikslas yra sudaryti miesto funkcinès ir kompozicinès struktūrų sąveikos tyrimo modelį, paremtą esamų lokalių didmiesčio centrų pavyzdžių analize, ir išnagrinèti jo taikymo galimybes, nustatant veiksmingos, efektyvios urbanistinès struktūros formavimo principus.

\footnotetext{
${ }^{4}$ Sovietiniais metais šiame moksliniame darbe įvardijamas laikotarpis nuo Lietuvos okupacijos ir aneksijos 1940 m. iki Lietuvos nepriklausomybès atkūrimo 1990 m., industrinès statybos laikotarpis - nuo 1955 iki 1990 m. Sovietiniais metais Lietuvos miestų raidą nulèmè 1954 ir 1955 m. nutarimai, kuriais buvo numatytos priemonès gerinti projektavimą, industrializuoti statybą ir „šalinti nesaikingumus“. Siekiant patenkinti didelị būsto poreikị, nuo $1955 \mathrm{~m}$. pradèta stambiaplokščių daugiabučių namų statyba, surenkamų pagal tipinius projektus iš standartinių elementų ir mazgų. Buvo nustatyti gyvenamujų rajonų planavimo prioritetai, teikiant pirmenybę gyvenamujų ir visuomeninių pastatų statybai remiantis visoje buvusios Sovietų Sajungos teritorijoje taikytais planavimo principais ir galiojusiomis statybos normomis (Miškinis 1991). ${ }^{5}$ Kasdienius gyventojų poreikius tenkinančios prekybos ir paslaugų i̇monès dar yra vadinamos traukos objektais.
} 


\section{Darbo uždaviniai}

Darbo tikslui pasiekti keliami šie pagrindiniai uždaviniai:

1. Išnagrinèti miesto funkcinès ir kompozicinès struktūrų tyrimų metodikas, kurios yra svarbios atsižvelgiant $\mathfrak{i}$ urbanistinio projektavimo dabartinę sampratą ir gyvybingų viešujų erdvių formavimo prioritetus.

2. Nustatyti daugiafunkcių didmiesčio centrų formavimo bendruosius uždavinius ir glaustai įvertinti Lietuvos didmiesčių lokalių centrų plètojimo galimybes.

3. Atskleisti urbanistinès erdvès savybių svarbą ir itaką lokalių centrų formavimosi procesui bei sujungti funkcinius ir kompozicinius urbanistinès struktūros analizès aspektus, remiantis esamų lokalių didmiesčio centrų pavyzdžiais.

4. Apibrèžti funkcinès ir kompozicinès struktūrų sąryšio ypatumus ir jų vertinimo galimybes, nustatant lokalių didmiesčio centrų urbanistinès struktūros formavimo principus.

\section{Tyrimų metodika}

Keliamos mokslo ir praktikos problemos sprendimo galimybès yra atskleidžiamos remiantis space syntax (erdvès sintaksès) metodika. Šios metodikos teorinis pagrindas - fundamentalieji ir taikomieji erdvès sandaros ir žmonių judejjimo pobūdžio priklausomybès nuo urbanistinès erdvès konfigūracijos tyrimai, kurie yra paremti judejjimo ekonomikos modeliu, nuo XX a. 8-ojo dešimtmečio pabaigos plètojami Billo Hillier ir kitu Londono universiteto koledžo (University College London) mokslininku (Hillier et al. 1976; Hillier, Hanson 1984; Hillier et al. 1993; Hillier 1999; 2007; Batty 2004; Hillier, Iida 2005; Chiaradia et al. 2009b).

Space syntax metodika pasirinkta dèl tiksliu (evidence-based) kiekybinių tyrimo metodų ir galimybès naudojant tą patį viso miesto modeli pereiti $\mathfrak{i}$ detalesnį urbanistinès erdvès lygmeni, siekiant ne tik pagrịsti konkrečios gatvès atkarpos galimybes būti kelionès tikslu arba maršruto dalimi, bet ir ịvertinti atskiru pastatų vaidmeni, atsižvelgiant i jų funkcijas, naudojimo tam tikrai veiklai galimybes. Šiame moksliniame darbe aprašomi space syntax metodikos pagrindiniai principai, atskleidžiamos jų taikymo galimybès, pateikiamos svarbiausių sąvokų apibrež̌tys. Sujungiant tikslių kiekybinių tyrimo metodų galimybes, matematiniams skaičiavimams naudojamos specializuotos kompiuteriu programos bei, vykdant natūrinius tyrimus, taikomi viešųų erdvių fotografavimo ir urbanistinę erdvę ribojančių užstatymo struktūros elementų vertinimo metodai. 
Siekiant atskleisti miesto funkcinès ir kompozicinès struktūrų sąryšio ypatumus yra tikslinga išsiaiškinti ịvairaus lygmens didmiesčių centrų, taip pat juos jungiančių pagrindinių gatvių išsidèstymą, jų tarpusavio ryšius ir funkcionavimo ypatumus. Nagrinejjant skirtingo lygmens centrų funkcines ir erdvines savybes bei vertinant jų urbanistinès kompozicijos ypatumus gali būti gaunami tokie rezultatai, kurie leistų apibrèžti naujų centrų formavimo ir esamų pertvarkymo principus.

Pasirinkta viešujų erdvių tyrimo metodika taikoma kitų šalių mokslininkų, nagrinejjant, pavyzdžiui, naujaisiais miestais vadinamų urbanistinių projektų, XX a. antroje pusèje igyvendintų Jungtinèje Karalystèje, prieštaringumus. Tačiau galima pastebèti, kad Jungtinès Karalystės ir kitų šalių mokslininkų tyrimai paprastai yra nukreipti ị urbanistinès erdvès sandarą, igyvendinant naujujų miestų ir jų dalių projektus suformuotos erdvès savybių ir socialinių bei ekonominių procesu mieste sąveiką. Šiame moksliniame darbe urbanistinès kompozicijos ir jos vizualinio suvokimo analize įtraukiama pasitelkiant Vytauto Jurkšto (1975; 1977; 1994) sudarytą tyrimų metodiką ir Algimanto Miškinio vadovaujamos autorių grupès (Miškinis 1974; 1991; Lietuvos... 2005) metodines rekomendacijas, parengtas vykdant Lietuvos miestų kompozicinès struktūros tyrimus. Svarbiausias urbanistinès struktūros tyrimų metodikos tobulinimo uždavinys yra minètų autorių moksliniuose darbuose kelto tikslo - taikant menines priemones pagerinti bendrą miesto ar jo dalies vaizdą - persvarstymas ir papildymas naujausių funkcinès struktūros tyrimo metodų galimybėmis ir, ieškant bendrų sąlyčio taškų, veiksmingos, efektyvios urbanistinès struktūros formavimo principų atskleidimas.

\section{Darbo mokslinis naujumas}

Disertacijoje pristatomas naujas, mažai ištirtas aspektas - urbanistinès kompozicijos vaidmens lokaliu ir globaliu lygmeniu, užtikrinant urbanistinès struktūros elementų funkcinị ir erdvinị sąryšị, nustatymo būdas, kuris yra taikomas sujungiant funkcinès ir kompozicinès struktūrų tyrimo metodų galimybes.

Lokalių didmiesčio centrų funkcinès ir kompozicinès struktūrų sąryšio ypatumai, naudojant urbanistinès erdvès struktūros geometrinius modelius, iki šiol nagrinèti fragmentiškai. Kai kurių užsienio mokslininku darbuose (Conroy Dalton, Bafna 2003; Claramunt, Winter 2007), pasitelkiant matematinio ir grafinio modeliavimo priemones, bandyta atskleisti apskaičiuotu pasiekiamumo verčių ir atskirų kompozicinès struktūros elementų - ašių, mazgų, dominančių ir kt. - išsidèstymo tarpusavio ryšị. Iš Lietuvos mokslininkų reikia paminèti Vilniaus, Kauno ir Klaipedos senamiesčiu savitumus nagrinejusị V. Jurkštą, kurio pasiūlytos urbanistinès kompozicijos tyrimo metodikos nebuvo siekiama per- 
svarstyti ir išplètoti, ịtraukiant gatvių tinklo ypatumų įvertinimą. Šiame moksliniame darbe stengiamasi sujungti funkcinius ir kompozicinius urbanistinès struktūros analizės aspektus - lokalių centru vietos ir vaidmens lokaliu ir globaliu lygmeniu nustatymo bei viešujų erdvių pobūdį atspindinčio urbanistinès kompozicijos savybiu įvertinimo.

Rengiant disertaciją pasiūlyta ir išplètota bei nagrinèjant Vilniaus miesto lokalių centrų pavyzdžius patikrinta urbanistinès struktūros tyrimų metodika, paremta pasaulyje plačiai taikomos space syntax metodikos ir metodinių rekomendacijų, gautų naudojantis Lietuvos miestų kompozicinę struktūrą tyrusių mokslininkų rezultatais, sinteze.

Remiantis sudarytu miesto funkcinès ir kompozicinès struktūrų sąveikos tyrimo modeliu, atliktas Vilniaus miesto lokalių centrų urbanistinès struktūros tyrimas, nustatyta jų vieta ir vaidmuo bei išsamiai išnagrinèti trys lokalūs centrai, esantys Vilniaus miesto šiaurès vakarų dalyje.

Apibendrinant tyrimų rezultatus, ịvertintos dẻl miesto plano neužbaigtumo ir (arba) neefektyvumo kylančių esamų lokalių centrų problemų sprendimo galimybès ir atskleisti būdai, padedantys išvengti šių problemų igyvendinant naujų lokalių centrų urbanistinius projektus.

\section{Darbo rezultatų praktinė reikšmė}

Sudarytas miesto funkcinès ir kompozicinès struktūrų sąveikos tyrimo modelis ir gauti rezultatai suteikia galimybę tęsti tyrimus nagrinejjant kitus aktualius pavyzdžius, taip pat taikyti šiame moksliniame darbe aprašytą tyrimų metodiką projektavimo veikloje.

Tyrimų rezultatai gali būti naudojami nustatant urbanistinès struktūros formavimo principus, lengvai pritaikomus urbanistinio projektavimo praktineje veikloje, leidžiančius priimti strateginius sprendimus, išnaudoti esamos struktūros galimybes ir siekti efektyvaus urbanistinès struktūros funkcionavimo.

\section{Ginamieji teiginiai}

1. Gauti rezultatai ir jų palyginimas su kitu tyrèjų rezultatais rodo, kad veiksmingas, efektyvus miesto planas leidžia užtikrinti susisiekimo ir bendravimo viešosiose erdvèse galimybes.

2. Dèl miesto plano neužbaigtumo ir (arba) neefektyvumo kylantys prieštaringumai išryškejja nagrinejjant lokalių ir globalių urbanistinès erdvès savybių santykị ir vertinant urbanistinès kompozicijos vaidmenị. 
3. Miesto funkcinès ir kompozicinès struktūrų sąveikos tyrimo modelis, integruojantis matematinio ir grafinio modeliavimo priemones ir urbanistinès kompozicijos ịvertinimo metodą, leidžia nustatyti veiksmingos, efektyvios urbanistinès struktūros formavimo principus.

4. Pateikiama tyrimų duomenų interpretacija ir apibendrinimai gali būti pritaikyti sprendžiant kompozicinių ašių išdèstymo uždavinį, kuri igyvendinus jos tampa tarpusavyje sujungtomis funkcinemis ašimis, užtikrinančiomis urbanistinès struktūros elementų funkcinị ir erdvinį sąryšị, jungiamumą ir susisiekiamumą bei socialinę interakciją.

\section{Darbo rezultatụ aprobavimas}

Disertacijos tema yra publikuoti 5 moksliniai straipsniai: trys - recenzuojamuose mokslo žurnaluose (Bučys 2009; 2010; 2013), vienas - recenzuojamoje užsienio tarptautinès konferencijos medžiagoje (Bučys 2012), vienas - recenzuojamoje Lietuvos konferencijos medžiagoje (Bučys 2008).

Disertacijoje atliktų tyrimų rezultatai buvo paskelbti šešiose mokslinėse konferencijose Lietuvoje ir užsienyje:

- 10-ojoje Lietuvos jaunujų mokslininkų konferencijoje „K. Šešelgio skaitymai - 2008“. Rokiškis, 2008 m. gegužès 8-9 d. Pranešimas „Kai kurios miesto užstatymo struktūros formavimo problemos“.

- Respublikinèje konferencijoje „Miesto struktūrinè ir kompozicinè plètra kintančiame kontekste“. Vilnius, $2008 \mathrm{~m}$. spalio $23 \mathrm{~d}$. Pranešimas „Struktūralistinio metodo taikymo galimybès urbanistiniame projektavime".

- 11-ojoje Lietuvos jaunujų mokslininkų konferencijoje „K. Šešelgio skaitymai - 2009“. Vilnius, 2009 m. gegužès 8 d. Pranešimas „Daugiafunkcių didmiesčio centrų formavimo bendrieji uždaviniai“".

- 12-ojoje Lietuvos jaunujų mokslininkų konferencijoje „K. Šešelgio skaitymai - 2010“. Vilnius, 2010 m. gegužès 14 d. Pranešimas „Lokalių centrų vieta ir vaidmuo hierarchineje didmiesčio centrų sistemoje: Vilniaus pavyzdys".

- 51-ojoje Rygos technikos universiteto tarptautineje konferencijoje. Ryga, 2010 m. spalio 7-8 d. Pranešimas „Coherence between functional and compositional structures of the city: outline of a methodological approach" [Miesto funkcinès ir kompozicinès struktūrų sąryšingumo tyrimo metodiniai principai]. 
- Aštuntajame tarptautiniame space syntax simpoziume (The Eighth International Space Syntax Symposium). Santjagas, 2012 m. sausio 3$6 \mathrm{~d}$. Pranešimas „Understanding coherence between functional and compositional structures of the city: a case study of local centres in Vilnius" [Miesto funkcinès ir kompozicinès struktūrų sąryšio problema: Vilniaus lokalių centrų pavyzdys].

\section{Disertacijos struktūra}

Disertaciją sudaro įvadas, trys skyriai, rezultatu apibendrinimas, naudotos literatūros ir autoriaus publikacijų disertacijos tema sąrašai ir keturi priedai.

Darbo apimtis yra 124 puslapiai, neskaitant priedu, tekste pateikiami 17 paveikslų ir 17 lentelių. Rengiant disertaciją buvo panaudoti 112 literatūros šaltinių.

\section{Padėka}

Autorius nuoširdžiai dèkoja moksliniams vadovams doc. dr. Gintarui Stauskiui ir prof. dr. Zigmui Jonui Daunorai, Vilniaus Gedimino technikos universiteto Urbanistikos katedros dèstytojams, ypač doc. dr. Inesai Alistratovaitei-Kurtinaitienei ir prof. Algiui Vyšniūnui, recenzentams doc. dr. Daliai Dijokienei ir doc. dr. Vytautui Petrušoniui už vertingas pastabas. Taip pat dékoja įmonès „Space Syntax Limited“ darbuotojams už konsultacijas ir metodinę pagalbą. Ačiū Christianui Schwanderiui už naudingus patarimus, kaip pristatyti Vilniaus miesto lokalių centrų tyrimo rezultatus. Nuoširdžiai ačiū artimiesiems ir draugams.

Stipendiją moksliniams tyrimams skyre Valstybinis studijų fondas, stipendiją už akademinius pasiekimus - Lietuvos mokslo taryba. Stažuotei ir moksliniams tyrimams gauta parama pagal Mokymosi visą gyvenimą / Erasmus programą (sutarties Nr. 2009/2010-LTVILNIUS02-PAF01). Išvyką i tarptautinị simpoziumą pristatyti mokslinių tyrimų rezultatus finansavo Lietuvos mokslo taryba (sutarties Nr. VIZIT-2-KON-072) ir Vilniaus Gedimino technikos universitetas. 



\section{1}

\section{Miesto funkcinès ir kompozicinès struktūrų tyrimų apžvalga}

Pirmajame skyriuje nagrinejjama miesto funkcinès ir kompozicinès struktūrų samprata, hierarchinè didmiesčio centrų sistema, apžvelgiamos lokalių didmiesčio centrų urbanistinès struktūros tyrimų metodikos, atskleidžiant space syntax metodikos ypatumus ir taikymo galimybes sprendžiant apibrèžtą tiriamają problemą, nustatomi daugiafunkcių didmiesčio centrų formavimo bendrieji uždaviniai. Šio skyriaus medžiaga buvo publikuota dviejuose straipsniuose: 10-osios Lietuvos jaunujų mokslininkų konferencijos straipsnių rinkinyje „K. Šešelgio skaitymai - 2008“ ir mokslo žurnale „Mokslas - Lietuvos ateitis: K. Šešelgio skaitymai - 2009“ (Bučys 2008; 2009).

\subsection{Miesto funkcinès ir kompozicinès struktūrų samprata}

İvairių laikotarpių kūrejjai - mąstytojai, filosofai, architektai, dailininkai - domèjosi miesto planavimu, ieškojo racionalios ir tobulos urbanistinès kompozicijos. Buvo sukurta daugybė universalių miesto modelių. Tačiau bandymai igyvendinti idealaus miesto idejją dažniausiai būdavo nesėkmingi. Pagrindiné šių nesėkmių 
priežastis yra ta, kad vienintelio tinkamo urbanistinès struktūros modelio negali būti, nes kiekvienas miestas turi individualių bruožų ir unikalių savybių, kurias lemia geografinè padètis, socialinès bei ekonominès, gamtinès ir klimato sąlygos, istorija ir kultūra.

Urbanistinè struktūra - sudètingas ir fenomenalus tyrimų objektas. Remiantis universalia struktūros sąvoka, jos turinys nusakomas teikiant pirmenybę tarpelementinei sąveikai, kuri lemia pačių elementų savybes, susijusias su jų padètimi sistemoje. Urbanistinè struktūra - miesto struktūros elementų išsidèstymo, jų tarpusavio ryšių ir funkcionavimo ypatumų visuma (Daunora et al. 2004). Šiame moksliniame darbe remiamasi prielaida, kad efektyvios miesto struktūros sąvokos turinys gali būti atskleidžiamas nagrinejjant funkcinès ir kompozicinès struktūrų sąryšio ypatumus.

Tiriant urbanistinę struktūrą yra būtina įvardyti jos elementus. Tai svarbu dèl jų neginčijamo vaidmens miesto raidos procese - išlikdami atsparūs išorinių veiksnių poveikiui šie elementai ilgainiui igyja vis didesnę reikšmę ir formuoja miesto ar jo dalies ịvaizdi (Rossi 1984). Pasak Hildebrando Frey, urbanistinès struktūros elementai yra susiję tam tikrais ryšiais ir tarpusavyje efektyviai sąveikauja: „skirtingų urbanistinès struktūros elementų visuma sudaro gerai funkcionuojančią (well-functioning), palankią žmogui (people-friendly) ir aplinkai (environment-friendly) miesto urbanistinę sistemą" (Frey 1999: 14).

H. Frey taip pat pažymi, kad miesto funkcionavimo efektyvumą užtikrina tam tikra minètų elementų funkcinio ir erdvinio sąryšio būsena, kuri priklauso nuo bendrai priimtinų plètros principų ir tradicijų, vadinamosios „erdvės socialinès logikos" (Hillier, Hanson 1984), galimai nulèmusios tradicinių (istorinių) miestų plètrą, arba nuo urbanistinio projektavimo sprendimų (Frey 1999). Šiame moksliniame darbe yra pabrěžiami svarbūs istorinių (savaime susiformavusių) miestų struktūros ypatumai ir jais paremti formavimo principai, kurie buvo nepagrịstai ignoruojami pertvarkant (perplanuojant) esamus miestus bei rengiant naujujų miestų ir jų dalių urbanistinius projektus ${ }^{6}$.

Urbanistinès struktūros elementai nustatomi atsižvelgiant ị nagrinëjamą lygmenị: miesto, jo dalies (rajono), kvartalų, kvartalus formuojančių pastatų grupių (kompleksų) ir juos jungiančių viešųjų erdvių. Reikia pabrèžti, kad pagrindinis vaidmuo tenka žmogui ir jo veiklos ypatumams: antropogeniniais (žmogaus suformuotais) elementais ịvardijami užstatymo struktūros bei urbanistinèje erdvèje išsidèstę susisiekimo ir inžinerinès infrastruktūros elementai. Urbanistinei kompozicijai įtakos taip pat turi gamtiniai elementai: parkai, skverai, esamos žaliosios jungtys ir kiti želdynai, išsiskiriantys žemès paviršiaus elementai (reljefas), upès ir vandens telkiniai.

\footnotetext{
${ }^{6}$ Istorinių miestų centrų pertvarkymų neigiamą įtaką viešųjų erdvių gyvybingumui, įtraukiant urbanistinių elementų vaidmens nustatymą, nagrinèjo Kayvanas Karimis (1998; 2000).
} 
Su urbanistinès struktūros sąvoka glaudžiai susijusi viešujų erdvių tinklo struktūra (structure of the urban grid). Tai siauresnè sąvoka, nes šios struktūros elementai yra gatvès, pėsčiujų takai, alejjos, aikštès, parkai, skverai ir kitos viešosios erdvès, kurios yra tarpusavyje sujungtos ir sudaro sistemą. Minètus elementus vaizduojant plane, žymimos vizualiai atskiros urbanistinès erdvès dalys (convex spaces), t. y. urbanistinè erdve $\dot{e}^{7}$ skaidoma i tiesiogiai ir vientisai suvokiamas bei lengvai suprantamas dalis. Remiantis vizualinio suvokimo, pagrịsto žmogaus regèjimo galimybėmis, ypatumais (kai kiekvienas taškas yra matomas iš visų kitų erdvėje esančių taškų), pirmiausia apvedami aikščių ir kitų didžiausių viešuju erdvių kontūrai, toliau žymimos mažesnès urbanistinès erdvès dalys, taip sudalinant visą nagrinëjamą urbanistinę erdvę. Kitas viešujų erdvių tinklo vaizdavimo plane būdas yra gatvès atkarpų tarp sankryžų, pesčiujų takų, alëjų ir kitų elementu geometrizavimas, kuriant tarpusavyje sujungtų linijinių elementu modelį (Hillier, Hanson 1984). Modelio taikymo galimybès aprašomos 1.3.3 skyrelyje.

Vizualiai atskirų urbanistinès erdvès dalių tyrimas padeda atskleisti funkcinius aspektus, susijusius su socialinès interakcijos ir urbanistinès erdvès naudojimo galimybėmis, pavyzdžiui, tinkamumu laisvai užsiimti tam tikra veikla ${ }^{9}$ : valgyti, atsisėdus (pavyzdžiui, gatvejje ant suoliuko arba prie stalo lauko kavinejje) ar stovint stebèti kitus žmones, tarpusavyje šnekètis, grožètis pastatais, gatvèvaizdžiu ar kitu reginiu etc. Viešųų erdvių tinklo linijinių elementų modelis kuriamas urbanistinès erdvès konfigūracijai - minètų elementų išsidèstymo, jų tarpusavio ryšių visumai - tirti (Hillier 1993).

Siekiant atskleisti skirtingų vaizdavimo būdų - naudojant vizualiai atskirų urbanistinès erdvès dalių arba linijinių elementų modelius - ypatumus, apibrèžtos funkcinès struktūros ir kompozicinès struktūros sąvokos.

Funkcinès struktūros sąvoka yra vartojama siekiant apibrěžti tam tikrą paskirti (funkciją) turinčių pastatų, pastatų kompleksų ar statinių, taip pat viešųjų erdvių išsidèstymo, jų tarpusavio ryšių ir funkcionavimo (pavyzdžiui, žmonių

\footnotetext{
${ }^{7}$ Urbanistinè erdvė apibrèžiama kaip užstatymo struktūros elementų ir gamtinių elementų (reljefo ir želdynų) ribojama trijų matmenų tuštuma, patenkanti ị žmogaus regejimo lauką (Alistratovaite 2004).

${ }^{8}$ Vizualiai atskiros urbanistinès erdvès (convex space) sąvoka yra susijusi su iš vienos miesto vietos $i$ kita judančio žmogaus galimybėmis lengvai suprasti savo buvimo vietą (tam tikrą erdvès dali lokaliu lygmeniu) ir tuo pat metu matyti besiribojančias (susisiekiančias) erdvès dalis (suprasti erdvès tęstinumą globaliu lygmeniu). Linijiniai elementai (linear elements) - vizualinės (arba netrukdomo judèjimo) ašys - sujungia šiuos du lygmenis ị visumą (Hillier 2007).

${ }^{9}$ Žmonių elgsenos viešosiose erdvèse ypatumus, galimybes užsiimti tam tikra veikla sèdint ar stačiomis (stationary activity) ir žmonių laisvam pasirinkimui įtakos turinčius veiksnius nagrinèjo Williamas Whyte'as (1980).
} 
judejjimo) ypatumų visumą ir jose vykstančius socialinius, ekonominius ir kultūrinius procesus.

Funkcinès ašys - urbanistinèje erdvejje besidriekiančios žmonių judejjimo kelių (maršrutų) dalys: gatvių, pėsčiujų ar dviračių takų atkarpos. Funkciniai mazgai - žmonių susibūrimo, ịvairių funkcijų susitelkimo, gatvių sankirtų ar susiliejimų vietos urbanistinèje erdvèje.

Remiantis Tarptautinių žodžių žodyne (2013) pateikiamomis žodžio kompozicija apibrèžtimis, iš kurių pirmoji - meno kūrinio elementų išdèstymas, jų tarpusavio ryšys ir santykis su visuma - gali būti vartojama apibūdinant urbanistinę kompoziciją, ị urbanistinès erdvės elementus, jų vaidmens įvertinimą, struktūros formavimą galima pažvelgti per architektūros mokslo ir praktinès veiklos prizmę. Tačiau reikia pabrèžti, kad miesto planas (taip pat ir siluetas, gatvėvaizdžiai) šiame moksliniame darbe suprantamas kaip savaiminio formavimosi ir urbanistinio projektavimo sprendimų veikiamas procesas, bet ne vieno autoriaus ar autoriu grupés kūrinys ${ }^{10}$. Plačiau apie urbanistinio projektavimo procesą ir jo dalyvius žr. 1.3.1 skyreli.

Kompozicinè struktūra - pastatų, pastatų kompleksų ar statinių, taip pat vizualiai atskirų urbanistinès erdvès dalių ir (arba) viešujų erdvių tinklo struktūros elementų išsidèstymo, jų tarpusavio ryšių visuma. Kompozicinių ašių ir mazgų išsidèstymas yra susijęs su užstatymo struktūros ir urbanistinès erdvès elementų meniniu ir vizualiniu potencialu ir žmogaus orientavimosi urbanistinëje erdvejje galimybèmis.

Kompozicinès ašys - urbanistinejje erdvejje besidriekiančios vizualinès ašys ar jų dalys, abipus kurių išsidèstę užstatymo struktūros elementai, globaliu lygmeniu - lokalius centrus jungiantys viešujų erdvių tinklo struktūros elementai. Kompoziciniai mazgai yra šie: lokaliu lygmeniu - kompozicinių ašių sankirtos, globaliu lygmeniu - miesto, jo dalių (pavyzdžiui, gyvenamujjų rajonų) centrai. Šiame moksliniame darbe svarbiais kompoziciniais mazgais laikomi vadinamieji vartai ị lokalu centrą (gateways to the local centre) ir gatvių sankirtos, iš kurių matoma vertikali ar horizontali dominante.

Nagrinejant miesto planą ir vertinant jo urbanistinès kompozicijos ypatumus galima pastebèti, kad pėsčiujjų, dviratininkų ir automobilių judejjimo keliai (maršrutai), įvairių funkcijų (prekybos, viešojo maitinimo ir kt.) susitelkimo vie-

${ }^{10}$ Architekto ar jo vadovaujamos grupès kūrybinès raiškos rezultatas - užbaigtas projektas - paprastai yra tik proceso dalis (Levin 1984). Apie mieste vykstančių socialinių ir ekonominių procesų ịvertinimo poreiki apibrèžiant tvarumo sampratą rašè Akkelies van Nes (2007). Tai, kad funkcijų pasikeitimai istoriniame miesto centre yra objektyvus reiškinys, savo moksliniame darbe pabrèžè ir Vytautas Jurkštas (1994). Galima palyginti silueto formavimą ir urbanistinio projektavimo sprendimų prièmimą planinès ekonomikos sąlygomis (nesant privačios nuosavybès) bei esant laisvai rinkai ir konkurencijai (Daunora et al. 2004). 
tos bei kompozicijos atžvilgiu svarbios viešujų erdvių tinklo dalys dažniausiai sutampa (šiame moksliniame darbe išryškinamas funkcinių ir kompozicinių ašių ir mazgų sutapimas). Prieš atskleidžiant vienas kitą dengiančių miesto funkcinès ir kompozicinès struktūrų elementų sluoksnių sudètinio vaizdavimo plane ir juo pagrịsto tyrimo ypatumus, yra tikslinga apibrèžti dominantès, arba dominuojančio elemento, sąvoką.

Dominuoti (lot. dominari) - vyrauti, būti svarbiausiam; būti aukščiau ko nors. Dominantè (lot. dominans) - pagrindinis elementas (Tarptautinių... 2013). Dominantè, arba dominuojantis elementas, - miesto kompozicinès struktūros elementas, išsiskiriantis iš kitų elementų: 1) pastatas, pastatų kompleksas ar statinys, išsiskiriantis iš ji supančių elementų aukščiu arba tūriu (vertinant kvartalo arba kvartalu grupès lygmeniu); 2) vizualiai atskira urbanistinès erdvès dalis arba viešųų erdvių tinklo struktūros elementas, kurio apskaičiuota pasiekiamumo verte yra aukštesnè, palyginti su kitais elementais. Vertikalia dominante (vertical dominant building) vadinamas pastatas, kuris yra ne mažiau kaip du kartus aukštesnis, palyginti su esamo užstatymo foniniu aukščiu ${ }^{11}$. Horizontalia dominante (horizontal dominant building) vadinamas išraiškingas pastatas, pastatų kompleksas ar statinys, kurio pagrindinis ar kitas gerai matomas fasadas išsiskiria iš esamo užstatymo.

Dominantėmis galima ịvardyti ir užstatymo struktūros, ir urbanistinès erdvès elementus, išsiskiriančius iš kitų elementų; paprastų, niekuo neišsiskiriančių elementų visuma dar vadinama fonu (background). Anglų kalbos terminai dominant building ir landmark yra artimi, bet netapatūs. Pirmasis reiškia svarbų gatvèvaizdžio elementą - pastatą ar statini, išsiskirianti iš esamo užstatymo, antrasis turi platesnę reikšmę $e^{12}$ ir yra susijęs su orientavimosi urbanistinejje erdvèje galimybèmis bei miesto ar jo dalies ịvaizdžiu (Lynch 1960; Klippel, Winter 2005). Šiame moksliniame darbe semantinis aspektas neliečiamas. Kalbant apie aukštus pasiekiamumo rodiklius turinčius viešųų erdvių tinklo struktūros elementus, jų tarpusavio ryšių visumą, vartojamas anglų kalbos terminas dominant pattern.

\footnotetext{
${ }^{11}$ Toks vertikalios dominantės nustatymo kriterijus (pastatas ne mažiau kaip du kartus viršija užstatymo foninị aukštị), atsižvelgiant ị semantinị urbanistinès ir gamtinès struktūrų santykị, pateikiamas Zigmo Jono Daunoros ir bendraautorių monografijoje (Daunora et al. 2004).

${ }^{12}$ Išvertus iš anglų kalbos, mark - orientyras, žymintis tam tikrą vietą mieste; landmark - krentantis ị akis objektas, gerai matomas orientyras, padedantis rasti ir (arba) suprasti reikiamą vietą mieste; gali būti svarbus viso miesto mastu (whole-city landmark arba global landmark) arba lokaliu lygmeniu (local landmark).
} 


\subsection{Lokaliụ didmiesčio centrụ ypatumai}

Šiame poskyryje atskleidžiama centro sąvoka yra vartojama urbanistinio projektavimo ir planavimo praktineje veikloje rengiant urbanistinès plètros koncepcijas ir kitus planavimo dokumentus. Remiamasi prielaida, kad lokaliu centru problemų, jų sprendimo galimybių ir būdų nagrinèjimas, pirmenybę teikiant lokalius centrus sudarančių viešujų erdvių trūkumus ir plètojimo galimybes atskleidžiantiems praktiniams pavyzdžiams, nei per daug supaprastintiems teoriniams modeliams, leidžia geriau suprasti dèl miesto plano neužbaigtumo ir (arba) neefektyvumo kylančius prieštaringumus. Susiformavusiems ar suformuotiems didmiesčio centrams apibūdinti Dabartinès lietuvių kalbos žodyne (2011) teikiamos kelios žodžio centras reikšmès: 1) kokių nors linijų susikirtimo taškas; 2) vidurinè, svarbiausia dalis, vidurys; 3 ) vieta, kur kas sutelkta; svarbiausia vieta erdvejje.

Didmiesčio centrą apibūdinantys požymiai, padedantys ji skirti nuo kitu miesto dalių, yra šie: 1) svarbi sankryža (important intersection) - pagrindinių gatviu susikirtimo vieta (kai kuriais atvejais gali būti svarbiausia pagrindinès gatvès atkarpa) - ir tankesnis viešujų erdvių tinklas (intensified urban grid); 2) centrinè padètis (centrality) kitų miesto dalių atžvilgiu; 3) prekybos, paslaugų, pramogu ir visuomeninių funkcijų sankaupa (spatial agglomeration), kai minètos funkcijos išsidesčiusios greta viena kitos ir yra tarpusavyje susijusios.

Daugiafunkciškumas arba mišrus naudojimas (mixed use) suprantamas kaip viena kitą papildančių funkcijų mišinys tam tikroje teritorijoje. Kaip priešprieša funkciniam zonavimui daugiafunkciškumo principo igyvendinimas yra vienas iš svarbiausių darnios plètros prioritetų (Juškevičius, Jauneikaitė 2008). Daugiafunkciai centrai yra svarbūs miesto struktūros elementai - ịvairaus lygmens urbanistiniai mazgai, kuriuose yra sutelktos prekybos, paslaugų, pramogų ir visuomeninès funkcijos.

Daugiafunkcių didmiesčio centrų formavimo bendrieji uždaviniai nustatyti remiantis mokslinių tyrimų rezultatais (Hillier 2007), Jungtinès Karalystès (toliau - JK) planavimo politikos gairèmis (PPS6... 2005), Jungtinių Amerikos Valstiju (toliau - JAV) standartais (Planning... 2006) ir kai kurias Lietuvos pavyzdžiais ${ }^{13}$ (Juškevičius, Valeika 2007; Šešelgis 1975).

Vienas iš aktualiu dokumentu yra JK Vyriausybès parengtos planavimo politikos gairès, paaiškinančios istatymų reikalavimus ir planavimo sistemos veikimą $^{14}$. Šiomis gairèmis naudojasi savivaldos institucijos rengdamos plètros

\footnotetext{
13 Taip pat buvo ịvertinti kai kurie Australijos didmiesčių centrų ypatumai (Siksna 1997; 1998; 2006), sutelkiant dèmesi ị viešujjų erdvių tinklo intensifikacijos galimybes ir ribas. ${ }^{14}$ Siekiant geriau suprasti JK planavimo politiką, yra tikslinga papildomai susipažinti su jos igyvendinimui skirtais (Planning... 2005) ir gerosios praktikos pavyzdžius aprašančiais dokumentais (Places... 1998; By Design... 2000).
} 
planus (development plans) ir spręsdamos kitus planavimo klausimus (PPS6... $2005)^{15}$. Amerikos planavimo asociacijos parengtame urbanistinio planavimo ir projektavimo žinyne (Planning... 2006) pateikiami JAV daugiafunkcių centrų formavimo bendrieji principai.

\subsubsection{Hierarchinè didmiesčio centrų sistema. Daugiafunkcių didmiesčio centrų formavimo bendrieji uždaviniai}

Hierarchinę daugiafunkcių ir vienfunkcių centrų sistemą sudaro pagrindinis (istorinis) miesto centras ${ }^{16}$, stambūs miesto dalių centrai (taip pat periferiniai, nutolę nuo pagrindinio centro) ir žemiausio lygmens lokalūs gyvenamujjų rajonų centrai ${ }^{17}$, specializuoti verslo, sporto, rekreacijos, mokslo ir medicinos centrai.

Pagrindinis didmiesčio centras - tai aukščiausio lygmens (paprastai regiono reikšmès) centras, kuriame sutelktos išskirtinès (arba reprezentacinès) funkcijos, epizodiškai lankomos įstaigos (valstybès ir savivaldos institucijos, švietimo, mokslo, kultūros ịstaigos ir kt.), mišrios paskirties prekybos, paslaugų ir pramogu objektai. Pagrindinis centras paprastai yra ir susisiekimo mazgas (transport interchange), kurio svarbiausi elementai - geležinkelio ir autobusų stotys. Tai žmonių srautu pasiskirstymo objektai, kuriuose užmiesčio gyventojai ir svečiai persèda į miesto viešaji transportą arba tęsia kelionę pèsčiomis.

Siekiant sumažinti gyventojų judrumą, transporto srautus ir didmiesčių centrinių daliu perkrovą, vis daugiau darbo vietu sutelkiama vidurinèse ir periferinèse dalyse esančiuose antriniuose centruose. Išlaikant pusiausvyrą ir tolygią funkcijų sklaidą skirtingo lygmens centruose, numatoma, kad gyventojų kasdienius poreikius galètų tenkinti pėsčiomis arba viešuoju transportu pasiekiami centrai, esantys arti gyvenamosios vietos (PPS6... 2005). Pavyzdžiui, gyvenamojo rajono centras turètų būti nutolęs ne daugiau kaip 700-1000 m nuo kraštinių namų.

Didmiesčių gyvenamuju rajonų dalys, kuriose yra sutelktos svarbiausios funkcijos, pagal plètojimo prioritetus ir jų išsidèstymą viena kitos atžvilgiu skirstomos i centro (arba centro branduolio) ${ }^{18}$, centro pakraščio (arba pereinamają teritoriją) $)^{19}$ ir už centro ribų esančią teritoriją ${ }^{20}$.

\footnotetext{
${ }^{15} 2012 \mathrm{~m}$. kovo 27 d. JK Vyriausybẻ paskelbė atnaujintą planavimo politikos dokumentą (National... 2012).

${ }^{16} \mathrm{JAV}$ didmiesčių centrų (downtown) svarbiausia dalis - centrinis verslo rajonas (central business district).

${ }^{17}$ Lokalus centras: JK - district centre arba local centre, JAV - neighborhood center.

${ }^{18}$ Centras (arba centro branduolys): JK - centre, JAV - center core.

${ }^{19}$ Centro pakraštys (arba pereinamoji teritorija): JK - edge-of-centre, JAV - transition area.

${ }^{20} \mathrm{Už} \mathrm{centro} \mathrm{ribų} \mathrm{esanti} \mathrm{teritorija:} \mathrm{JK} \mathrm{-} \mathrm{out-of-centre,} \mathrm{JAV} \mathrm{-} \mathrm{background} \mathrm{neighborhood.}$
} 
Centrai gali būti skirstomi ị dvi kategorijas: pertvarkomi (perplanuojami) ir naujai formuojami. Plètojant esamus centrus susiduriama su šiomis problemomis: investicijų skatinimo, centro įvaizdžio ir savitumo stiprinimo, vertingujų savybių išsaugojimo, centro ribų išplètimo ir kt.

Ivairiuose planavimo dokumentuose pirmenybè teikiama esamų centrų tankiam užstatymui ir jų užimamos teritorijos efektyviam naudojimui ${ }^{21}$. Pirmiausia turi būti rekonstruojami esami pastatai, keičiama jų paskirtis, užstatomi laisvi (pastatų neužimti) sklypai - ir tik išnaudojus visas galimybes ieškoma naujų teritorijų centro plètrai už jo ribų (PPS6... 2005). Kiekvieną kartą plečiant centrą turi būti užtikrinamas geras naujų teritorijų pasiekiamumas pėsčiomis.

Nauji centrai formuojami tose miesto dalyse, kuriose numatoma aktyvi plètra arba ten, kur trūksta prekybos ir paslaugų objektų gyventojų kasdieniams poreikiams tenkinti. Pirmenybè turi būti teikiama apleistoms (degradavusioms) ir pertvarkomoms teritorijoms. Parenkant naujų centrų vietas turi būti atsižvelgiama ir ị numatomus susisiekimo infrastruktūros plètros sprendimus.

Daugiafunkcių centrų struktūra nuolat kinta. Esamų centrų augimo ir nykimo, naujų centrų formavimosi procesui ịtakos turi ịvairūs išoriniai veiksniai. Gyvenamujų rajonų centrų reikšmè sumažèja intensyviai plètojant stambius periferinius centrus, o dalị pastarujų funkcijų perima privatūs prekybos ir pramogų kompleksai. Centrų raidos procesui, jų gyvybingumui ${ }^{22}$ ir galimybėms pletotis (t. y. pritraukti investicijų pletrai, pertvarkymui ir prisitaikyti prie kintančių visuomenès poreikių) įtakos gali turèti susisiekimo sąlygu pasikeitimas, pavyzdžiui, gatvių tiesimas, sankryžų rekonstrukcija, naujų viešojo transporto linijų irengimas arba naujos transporto rūšies naudojimas ir pan. (Hillier 1999). Taigi susisiekimo sąlygos, ị centrą vedančių bei ji su kitais centrais jungiančių pagrindinių gatvių išsidèstymas yra svarbus veiksnys, dèl kurio centras pritraukia ne tik vietos gyventojų, bet ir lankytojų iš kitų miesto dalių. Tai padeda užtikrinti jo gyvybingumą ir galimybes plètotis.

Lokaliuose centruose paprastai įsikuria kasdienius gyventojų poreikius tenkinančios prekybos ir paslaugu ịmonès (parduotuvė, restoranas, baras arba kavine, vaistinè, paštas, banko skyrius, spaudos kioskas, kirpykla, savitarnos skalbykla), biurai ir įstaigos (komercinès, privačios, viešosios, valstybinès). Taip pat turi būti numatytos galimybès plètoti visuomeninę veiklą. Atsižvelgiant ị vietos sąlygas ir bendruomenès poreikius gali būti integruojami kultūros objektai (biblioteka, teatro arba kino sale, galerija), jeigu nenumatyta vietos gyvenamojo rajono viduje (t. y. atokiau nuo pagrindinių gatvių esančiuose kvartaluose) - ir pra-

\footnotetext{
21 Tankiai užstatyto miesto privalumai ir trūkumai paprastai yra atskleidžiami remiantis istorinių Europos miestų pavyzdžiais (Jenks 1996).

${ }^{22}$ Gyvybingumas arba miesto viešujų erdvių gyvybingumas (vitality arba urban vitality) yra susijęs su socialinès interakcijos (bendravimo viešosiose erdvèse) ir urbanistinès erdvès naudojimo galimybėmis.
} 
dinè mokykla, vaikų darželis, maldos namai ir kt. (Planning... 2006; PPS6... 2005).

Pageidautina daugiafunkciuose centruose numatyti ir gyvenamają funkciją, dèl kurios centras yra gyvybingas skirtingu paros metu. Esamus centrus pritaikant naujoms reikmėms, keičiantis jų funkcinei struktūrai arba formuojant naujus centrus turètų būti vertinama, ar numatomos funkcijos yra priimtinos ir suderinamos, t. y. ar neprieštarauja viena kitai (arba kitaip - „nekonfliktuoja“), pavyzdžiui, gyvenamoji ir komercinè (restoranai, barai, naktiniai klubai) - ar nekyla konflikto dèl triukšmo.

Hierarchinès sistemos modelį, paremtą centrinių vietų teorija, pasiūlè Walteris Christalleris (1933). Šiame moksliniame darbe minètas modelis nèra plačiau nagrinejjamas dèl šiu priežasčių: 1) tai per daug supaprastintas modelis, susijęs su prekybos ir paslaugų funkcijų tolygiu išsidèstymu tam tikroje teritorijoje, remiantis prielaida, kad lokalaus centro lankytojas pasirenka artimiausią traukos objektą; 2) modelyje nèra atspindètos lokalių centrų galimybès plètotis, jų pasiekiamumas vertinamas neatsižvelgiant ị urbanistinès erdvès konfigūraciją bei žmonių judèjimo ir viešųų erdvių tinklo ypatumus. Kadangi tikrovė yra daug sudètingesnè, W. Christallerio parengtas traukos objektų išdėstymo rekomendacijas yra keblu igyvendinti tam tikrose miesto dalyse esant nevienodoms susisiekimo sąlygoms. Todèl šiame moksliniame darbe pasirinktas geometrinio miesto modelio ypatumus ivvertinantis pasiekiamumo matavimo būdas ir ji pagrindžianti teorija, kurios svarbiausias argumentas - didmiesčio centrų hierarchija yra tiesiogiai susijusi su viešųų erdvių naudojimu susisiekti.

\subsubsection{Lietuvos didmiesčių lokalių centrụ plètojimo galimybès}

Moksliniame darbe daugiausia dèmesio skiriama vidurinèse ir periferinèse didmiesčių dalyse esančių lokalių centrų problemoms. Kai kurios jų plètojimo galimybès iliustruojamos Vilniaus lokalių centrų pavyzdžiais. Sovietiniais metais Lietuvos didmiesčių lokaliuose centruose, remiantis pakopinio gyventojų aptarnavimo principais, buvo sutelktos kasdienio ir periodinio lankymo įmonès ir ìstaigos. Dauguma šių centrų buvo sèkmingai pritaikyti prie rinkos ekonomikos sąlygų, tačiau kai kurių galimybès pritraukti lankytojų, neivvykdžius esminio jų struktūros pertvarkymo, yra ribotos. Kaip rodo užsienio patirtis, efektyviausiai funkcionuoja arti pagrindinių gatvių sankryžu, viešojo transporto stotelių arba persėdimo iš vienos transporto priemonès i kitą vietų esantys centrai. Moksliniame darbe nèra nagrinèjamos centrinès didmiesčių dalys bei geležinkelio, au- 
tobusų stočių ir oro uostų urbanistiniai mazgai, kurie pritraukia vis daugiau prekybos, paslaugų ir verslo funkcijų ir taip igyja vis didesnę reikšmę $e^{23}$.

Vidurinèse ir periferinèse Lietuvos didmiesčių dalyse esančių centrų stiprinimas yra aktuali problema, iškelta dar prieš atkuriant Lietuvos nepriklausomybę (Daunora 1989). Problemos sprendimo būdai pasiūlyti $1998 \mathrm{~m}$. rengiant Vilniaus miesto bendraji planą (Daunora 1995; Vilniaus miesto... 1999). Lokalius centrus numatyta plètoti ir $2007 \mathrm{~m}$. patvirtintame Vilniaus miesto bendrajame plane iki 2015 m. (Vilniaus miesto... 2006), tačiau jų formavimo uždaviniai nèra aiškiai apibrèžti ${ }^{24}$.

Šiame skyrelyje siekiama atskleisti Lietuvos didmiesčių lokalių centru galimybes efektyviai funkcionuoti ir pritraukti lankytojų, konkuruojant su šiuo metu dominuojančiais privačiais prekybos ir pramogu kompleksais, mažinant gyventojų judrumą, transporto srautus ir centrinių didmiesčių dalių perkrovą.

Vidurineje ir periferineje Vilniaus miesto dalyse esantiems lokaliems gyvenamųjų rajonų centrams konkurenciją sudaro greta aukštų kategorijų magistralinių gatvių ikurti prekybos ir pramogų kompleksai ${ }^{25}$. Geras privažiavimas, erdvios automobiliu stovèjimo aikštelès ir kiti susisiekimo sprendimai pritaikyti pagrindinių šių centrų lankytojų - žmonių, turinčių lengvajji automobilį ir retai besinaudojančių viešuoju transportu - patogumui (Juškevičius, Valeika 2007).

Dauguma Vilniaus priemiestyje po $1990 \mathrm{~m}$. išplitusių individualių gyvenamụjų namų kvartalų neturi socialinès infrastruktūros ir lokalių paslaugų centrų. Šių kvartalų gyventojai, privačiu automobiliu važinejjantys ị darbą mieste, prekybos ir pramogų kompleksuose yra priversti lankytis tenkindami kasdienius poreikius.

Viena iš priežasčių, kodèl žmonès tenkina kasdienius poreikius lengvuoju automobiliu vykdami i prekybos ir pramogų kompleksus, yra žema lokalių centrų viešujų erdvių kokybé ${ }^{26}$. Todèl daugiau demesio turi būti skiriama lokalių

\footnotetext{
${ }^{23}$ Problema yra ta, kad plètojant geležinkelių infrastruktūrą ne visada skiriama pakankamai dėmesio stotis supančio gatvių tinklo galimybèms (Van Nes, Stolk 2012).

${ }^{24}$ Taip pat buvo ịvertinti kitų Lietuvos didmiesčių bendrieji planai (Kauno miesto... 2003; Klaipèdos miesto... 2007; Šiaulių miesto... 2008). Nagrinètuose dokumentuose neịvardijama vietų lokaliems centrams parinkimo ir jų vaidmens nustatymo problema. ${ }^{25}$ Prekybos ir pramogų kompleksai (shopping and entertainment centres), kai kuriu autorių dar vadinami hipercentrais (Juškevičius, Valeika 2007), - tai privatūs objektai, kuriuose prekybinès patalpos išdėstytos abipus pėsčiųų gatvių ir aikščių struktūrą atkartojančių pasažų ir galerijų.

${ }^{26}$ Pastarujų metų mokslo publikacijose Lietuvos didmiesčių viešujų erdvių kokybès problematikai skiriama daug demesio (Dringelis 2005; Stauskas 2006; Stauskis, Eckardt 2011; Buivydas, Samalavičius 2011). Viešujų erdvių kokybès problema taip pat aktuali gretimose šalyse, pavyzdžiui, pateikiamos rekomendacijos, kaip užtikrinti Rygos senamiesčio gyvybingumą ir galimybes plètotis (Bratuškins 2006).
} 
centrų urbanistinès aplinkos kokybei, didinant jų investicini patrauklumą, skatinant plètrą ir renovaciją.

Sovietinių metų statybos (1955-1990 m.) gyvenamuosiuose rajonuose istorinè gatviu paskirtis, sujungianti susisiekimo ir bendravimo funkcijas ${ }^{27}$, buvo ignoruojama (Šešelgis 1975). To meto planavimo normatyviniuose dokumentuose buvo išdèstyti reikalavimai automobilių eismą atskirti nuo pėsčiujjų. Tačiau daug dèmesio skiriant eismo saugumo problemoms spręsti, pėsčiujų zonų urbanistinès aplinkos kokybès, gyvybingumo ir gyventojų saugumo užtikrinimo klausimai dažniausiai likdavo nuošalyje.

Aktuali Lietuvos didmiesčių problema yra lokalių centrų struktūros pertvarkymas ir tolesnis plètojimas, pritraukiant kasdienes paslaugas teikiančias įmones ir visuomenines organizacijas, kuriant naujas darbo vietas (Vilniaus miesto... 2006). Kai kurie lokalūs centrai yra suformuoti gyvenamujų rajonų viduje atokiau nuo pagrindinių gatvių. Vienas iš būdingų Vilniaus miesto pavyzdžių yra Fabijoniškių lokalus centras, kurị sudaro seniūnija, teatro salè, keleto bendrovių biurai, parduotuve, vaistine, kepykla ir kitos i rajono gyventojų poreikius besiorientuojančios smulkios prekybos ir paslaugų įmonès. Panašioje padettyje yra ir Pašilaičiu (Medeinos gatvès) lokalus centras (parduotuvè, vaistinè, kavinè, kirpykla ir kitos paslaugos). Projektuojant minètus centrus nebuvo atsižvelgta i bendrąsias rekomendacijas, pagal kurias gyvenamujų rajonų paslaugų centrai turejo būti greta viešojo transporto stotelių ir pagrindinių pėsčiųjų judejjimo kelių (maršrutu).

Vienas iš Lietuvos didmiesčių lokalių centru problemos sprendimo būdų perkelti prekybos ir paslaugų funkcijas iš neefektyviai funkcionuojančių centrų $i$ naujai formuojamus, esamus pastatus pritaikant visuomeninei paskirčiai ir bendruomenès poreikiams, kitas būdas - atnaujinti ir stiprinti esamus centrus gerinant jų pasiekiamumą, pavyzdžiui, tankinant gatvių tinklą: tiesiant naujas gatves gyvenamujų rajonų viduje ir įrengiant viešojo transporto stoteles. Šios dvi prielaidos, ivvertinus urbanistinio projektavimo praktineje veikloje taikomos tyrimų metodikos galimybes, tikrinamos vykdant antrajame skyriuje pristatomus tyrimus.

Kitokioje padètyje yra intensyviai plètojamas Šeškinès lokalus centras, suformuotas prie magistralinès gatvès, todèl pritraukiantis ne tik rajono gyventojus, bet ir pravažiuojančius lankytojus. Šiuo metu centre vyrauja komercinès paskirties objektai, yra per mažai visuomeninių įstaigų (viena iš intensyviausiai lankomų - poliklinika) ir visiškai neintegruota gyvenamoji funkcija. Svarbiausia problema yra ta, kad urbanistiné centro struktūra plètojama nesiremiant bendra koncepcija, todèl kai kurie jos elementai - nesutvarkytos viešo-

${ }^{27}$ Gatvès erdvès savybės ir jos naudojimo būdai (pavyzdžiui, susitikimo ir bendravimo vieta, žmonių judejimo ir kroviniu pervežimo koridorius) turi didelès ịtakos socialiniam ir ekonominiam gyvybingumui (Hillier 2007). 
sios erdvès, i Š Šškinès gatvę atkreiptos aklinos pastatų fasadų plokštumos ir ūkiniai kiemai bei atsitiktinèse vietose ịrengtos laikinos prekyvietės - turi neigiamos įtakos centro įvaizdžiui ir funkcionavimo kokybei.

Vertinant strategiškai svarbioje vietoje įkurto Šeškinès centro užstatymo ir funkcinę struktūrą reikètų pastebèti, kad esama daug galimybių plètrai. Vienas iš racionaliausių būdų pertvarkyti centro prieigas yra nauju pastatų fasadus nukreipti i gatvès erdvę, užstatant neišnaudotas erdves ir esamas automobilių stovejjimo aikšteles, pastarąsias įrengiant daugiaaukščiuose priestatuose kvartalo viduje arba po žeme. Šių sprendimų pagrịstumą ir reikšmę formuojant gyvybingas viešąsias erdves dar reikia patikrinti - kitame poskyryje pateikiama autoriaus išankstini požiūrị galinčios patvirtinti arba paneigti tyrimų metodikos apžvalga.

\subsection{Lokalių didmiesčio centrų urbanistinès struktūros tyrimų metodika}

\subsubsection{Urbanistinio projektavimo dabartinè samprata}

Svarstant keliamą mokslo ir praktikos problemą bei ieškant jos sprendimo galimybiu yra siekiama sujungti gerai žinomuose darbuose (Carmona et al. 2003; Madanipour 1996; Moughtin et al. 1999), kuriuose demesys sutelkiamas ị viešųjų erdvių formavimo problemas, pateikiamą urbanistinio projektavimo dabartinę sampratą ir matematinio modeliavimo priemonių taikymu išsiskiriančią space syntax teoriją ir metodiką (Hillier, Hanson 1984; Hillier 2007), kuri yra aktuali architektams, siekiantiems geriau suprasti gyvybingų viešujų erdvių ir socialinės bei ekonominès veiklos mieste ryši. Moksliniame darbe nesiekiama sukurti naujos sampratos ar tikslinti šiame poskyryje pristatomų autorių pasiūlytų sąvokų apibrežčių. Stengiamasi pateikti bendrai priimtinus urbanistinio projektavimo aspektus, kuriais remiamasi sudarant tyrimo modeli ir nagrinejant jo naudojimo galimybes.

Urbanistinis projektavimas (urban design) - esamų miestų ir jų dalių urbanistinès struktūros pertvarkymas (perplanavimas) ir naujųjų miesto dalių urbanistinès struktūros formavimas. Urbanistinio projektavimo procesas apima urbanistinès erdvės ir užstatymo formavimą, miesto viešųjų erdvių sistemos kūrimą, dažniausiai nesprendžiant pastatų architektūrinio projektavimo (pastatų vidaus erdvių formavimo) klausimų. Svarbus urbanistinio projektavimo proceso aspektas yra urbanistinę erdvę formuojančių pastatų fasadų plokštumų ir architektūrinių savybių itakos nustatymas, ịtraukiant pagrindinių įejjimų i pastatus 
vietas $^{28}$. Kitas aspektas - pastatų vaidmens, atsižvelgiant i jų funkcijas, naudojimo tam tikrai veiklai galimybes, ivvertinimas. Urbanistinis projektavimas - ịvairių specialistų (architektų, miestų planuotojų, kraštovaizdžio architektų, inžinierių ir kt.) bendradarbiavimu pagrịstas tarpdisciplininis procesas, reikalaujantis jų igūdžių, kompetencijos ir profesinès patirties. Kita vertus, Vakarų šalyse dedamos pastangos i š š procesą įtraukti visuomenę ir skatinama ieškoti urbanistinès struktūros formavimo problemų sprendimo būdų, atitinkančių viešaji interesą (Carmona 2001). Remiantis iš Vakarų perimta bendruomenių dalyvavimo urbanistinio projektavimo sprendimų prièmimo procesuose tradicija, savivaldos institucijos yra ịpareigotos sudaryti sąlygas visuomenei susipažinti su plètros planais, teikti pastabas ir pasiūlymus.

Urbanistinio projektavimo tikslas - tobulinti miesto ir jo dalių urbanistinę struktūrą ir fizinę aplinką. Vienas iš svarbiausių urbanistinio projektavimo uždavinių yra gyvybingų viešųų erdvių kūrimas ir plètojimas. Projektuojami urbanistinès struktūros elementai turi būti žmogiškojo mastelio ${ }^{29}$. Kitas svarbus aspektas - priimamų sprendimų kontekstualumas, būtinybė atsižvelgti i pastatus supančios aplinkos (su urbanistiniu kontekstu susijusius), gretimų kvartalų ir juos jungiančių viešųjų erdvių formavimo sprendimus, siekiant išsaugoti miesto ar jo dalies savitumą (Norberg-Schulz 1980).

Urbanistinio projektavimo samprata pradèta išsamiau nagrinèti XX a. antroje puseje. Galima ịvardyti šiuos užsienio teoretikus ir praktikus, kurių darbai turèjo didelès ịtakos sparčiai besiplètojančiai mokslo ir praktikos sričiai: Keviną Lynchą, Jane Jacobs, Gordoną Culleną, Edmundą Baconą, Robertą Venturi, Janą Gehlį, Christoperị Alexanderị, Coliną Rowe'ą ir Fredą Koetterį.

Vienas pirmuju urbanistinio projektavimo terminą pavartojo Camillo Sitte. $1889 \mathrm{~m}$. išleistoje knygoje „Miesto planavimas remiantis jo meniniais principais“ (Der Städtebau nach seinen künstlerischen Grundsätzen) jis pabrèže erdvès savybių įvertinimo svarbą urbanistinio projektavimo procese, užtikrinant viešujų erdvių kokybę ir savitumą (Sitte 1945).

Modernistinio judejimo (modernist movement) atstovai (Le Corbusier ir kiti) C. Sitte teoriją atmeté, tačiau ji vèl tapo aktuali XX a. 7-ajame dešimtmetyje Šiaurès Amerikoje kilus pasipriešinimo modernistiniam judèjimui bangai. Jane Jacobs, remdamasi savo stebejimais ir patirtimi, kritikavo modernistinio miestų planavimo ir plètros politiką, neatsižvelgiančią $i$ visuomenés poreikius, žmonių ir urbanistinès aplinkos tarpusavio sąveiką (Jacobs 1961).

${ }^{28}$ Miesto savitumo, tapatumo ir su juo glaudžiai susijusių aiškių urbanistinès erdvès ribų suformavimo, urbanistinę erdvę ribojančių pastatų fasadų plokštumų ir jų architektūrinių savybių, ypač langų ir durų angų išdèstymo, ịvertinimo svarbą išryškino Christianas Norberg-Schulzas (1980) ir Vytautas Petrušonis (2002; 2011).

29 Žmogiškojo mastelio terminą savo moksliniuose darbuose vartojo Vytautas Jurkštas (1977) ir Janas Gehlis (1987). 
Kevinas Lynchas, nagrinėdamas miesto ịvaizdį, apibendrino tyrimo - gyventojų apklausos dèl miesto vizualinio suvokimo ir orientavimosi jame - duomenis ir apibrèžè urbanistinès struktūros vertinimo metodiką (Lynch 1960).

Urbanistinès erdvès suvokimo problemą nagrinejo Gordonas Cullenas (1961), sukūręs nuosekliai kintančio vaizdo (serial vision) fiksavimo metodiką, atkurdamas pastoviu greičiu judančio stebètojo regimus (existing views) ir palaipsniui atsiveriančius vaizdus (emerging views). G. Culleno sudaryta urbanistinès erdvès analizès metodika yra paremta asmeniniu vertinimu ir interpretacija, todèl gauti rezultatai nèra objektyvūs.

Edmundas Baconas ịvairiais aspektais aptare urbanistiniam planavimui ir projektavimui itakos turinčius veiksnius: miesto augimo procesą, gamtos, užstatymo struktūros, erdvès ir žmonių tarpusavio santykị (Bacon 1967).

Architektas Robertas Venturi - postmodernizmo judèjimo pradininkas Šiaurès Amerikoje vyravusi funkcionalizmą vertino kritiškai ir pasiūlè alternatyvų požiūrị. Pagrindinis principas, kuriuo rémési projektuodamas naujus pastatus, formuodamas urbanistinius kompleksus ir kuri išryškino savo knygoje, buvo kontekstualios ir su sudètinga miesto struktūra sąveikaujančios architektūros ir gyvybingos urbanistinès aplinkos kūrimas (Venturi 1966).

Janas Gehlis nagrinejjo viešosiose erdvėse vykstančiu procesų ir urbanistinès aplinkos kokybès sąveiką (Gehl 1987). Colinas Rowe'as ir Fredas Koetteris, vertindami XIX a. architektų pasiekimus ir remdamiesi C. Sitte darbais, daugiausia dèmesio skyrè naujiems urbanistinio projektavimo ir analizès būdams, pagrįstiems viešųų erdvių formavimo principais, kurti (Rowe, Koetter 1978).

Christoperis Alexanderis ir bendraautoriai parenge architektūrinio ir urbanistinio projektavimo sprendimus pristatančią monografiją, kurioje keliamos taikant modernistinio planavimo principus suprojektuotų miestu problemos ir siūlomi jų sprendimo būdai (Alexander et al. 1977). Taip pat reikia paminèti vieną iš pirmujų C. Alexanderio straipsnių, kuriame kritikuoti funkcinio zonavimo, pésčiujų ir automobilių srautų atskyrimo ir kiti per daug supaprastinto požiūrio ị miestu planavimo problemas aspektai (Alexander 1965).

Stephenas Marshallas, pabrèždamas viešujų erdvių kokybės užtikrinimo reikšmę, nagrinèjo žmonių judejjimo ir gyvybingu viešujų erdvių - bendravimo vietų - kūrimo suderinamumo problemą, kuri yra aktuali, nes XX a. urbanistinio projektavimo ir planavimo praktineje veikloje minèta problema nebuvo keliama arba jai spręsti nebuvo skiriama dèmesio (Marshall 2004). Apibendrindamas daugiau kaip pusę amžiaus trunkantị intensyvaus urbanistinio projektavimo dabartinès sampratos formavimosi etapą, jis išskyrè K. Lyncho, G. Culleno, J. Jacobs ir C. Alexanderio darbus (vadinamąsias tradicines urbanistinio projektavimo teorijas), pripažindamas minètų teoretikų ir praktikų indèlį sukuriant tvirtą teorinị pagrindą, kurio šių dienų mokslininkai nepabandè labiau ịtvirtinti, tačiau ir siūlydami alternatyvų požiūrị neįstengè išjudinti (Marshall 2012). 


\subsubsection{Urbanistinès struktūros tyrimai Lietuvoje}

Urbanistinio projektavimo sampratai savo moksliniuose darbuose daug dèmesio skyrė Zigmas Jonas Daunora. Pranciškus Juškevičius nagrinejjo miesto plètros, susisiekimo ir kitus procesus, miesto struktūros ịtaką susisiekimo sistemos funkcionavimui. Miesto sociologijos sampratą, miesto funkcionavimo ypatumus sociologiniu aspektu nagrinejjo Jurgis Vanagas. J. Vanago parengtuose vadovèliuose urbanistinès kompozicijos sąvoka vartojama plačiąja prasme: ịtraukiamas ir atskirų urbanistinių elementų išdèstymas, išryškinant jų menini potencialą, ir viso miesto plano formavimo procesas (Vanagas 2003; 2008). Lietuvos miestų kompozicinès struktūros ir jų istorinès raidos tyrimus vykdè architektas Algimantas Miškinis ir jo vadovaujama autorių grupe (Miškinis 1974; 1991; Lietuvos... 2005). Miesto morfologinę struktūrą ir jos pakitimus nagrinèjo Inesa Alistratovaitè $(2004 ; 2008 ; 2009)$. Miesto viešujų erdvių tyrimo ir vertinimo principus, pagrịstus socialinio ir kultūrinio konteksto charakteristikomis, nustate ir viešujų erdvių sistemos formavimo dèsnius apibrěžè Tomas Grunskis (2002). Miesto ịvaizdžio tyrimo ir formavimo galimybes savo disertacijoje nagrinejo Salvinija Kirvaitienè (2007).

Svarstant keliamą mokslo ir praktikos problemą, yra aktuali Vytauto Jurkšto sudaryta urbanistinès kompozicijos ir jos vizualinio suvokimo tyrimų metodika (Jurkštas 1975; 1977; 1994). Iš 1.3 .1 skyrelyje ịvardytų užsienio autorių, K. Lynchas ir G. Cullenas paminèti V. Jurkšto darbuose ir jais remtasi planuojant tyrimus. Pabrèžta savitus miesto bruožus formuojančių urbanistinès struktūros elementų svarba nagrinèjant urbanistinę kompoziciją. Pasak V. Jurkšto, nagrinejjant miesto kompozicinę struktūrą ir siekiant išsiaiškinti urbanistinès struktūros formavimo(si) procesui būdingus dèsningumus, kai atskiri objektai - urbanistinès erdvès ir užstatymo struktūros elementai - yra sujungiami ir (arba) susijungia ị visumą, reikia ịvertinti vizualiai atskirų urbanistinès erdvès dalių ${ }^{30} \mathrm{kom}-$ poziciją ir kiekvieno pastato vaidmeni lokaliu ir globaliu lygmeniu (Jurkštas 1994).

V. Jurkšto sudaryta vizualinio suvokimo tyrimų metodika apima silueto ir panoramų bei miesto viešujų erdvių kompozicijos analizę. Silueto ir panoramų tyrimo metu nustatomos ap̌̌valgos vietos, iš kurių matomas miesto vaizdas, ir, užfiksavus nuotraukose, grafiškai analizuojama urbanistine kompozicija. Metodas buvo taikytas tiriant Vilniaus miesto centrinès dalies miestovaizdžių struktūrą ir nustatant vizualinio identiteto plètojimo galimybes (Daunora et al. 2004). Minèto tyrimo dèmesio centre buvo daugiaplanis aplinkos suvokimas - vienas iš svarbių Vilniaus miesto įvaizdžio bruožų.

\footnotetext{
${ }^{30}$ Atskirai urbanistinès erdvès daliai apibūdinti V. Jurkštas vartojo terminą nominali erdvè (Jurkštas 1994).
} 
Šiame moksliniame darbe silueto ir panoramų tyrimas yra tik papildoma priemonè, visas dėmesys kreipiamas į urbanistinę erdvę, kurioje žmogus yra apsuptas užstatymo struktūros elementų, t. y. jo regejjimo lauką riboja vizualinèmis kliūtimis ìvardijami pastatų fasadai ir aklinos tvoros. Nustatant bendras miesto ar jo dalies kompozicijos savybes, vertinami iš statiškų stebejimo tašku matomi miesto viešujų erdvių (gatvių, aikščių ir kt.) vaizdai ir atskirų pastatų įtaka $^{31}$. V. Jurkštas pabrèžè vertikalių dominančių reikšmę miesto kompozicijai. Jos suteikia miestui išskirtinumo, nes siluetas ir gatvėvaizdžiai tampa unikalūs ir lengvai atpažistami. Individualius kompozicijos bruožus turi tos urbanistinès erdvès dalys, kurios ịsilieja ị darnią visumą ir kuriose matoma dominanté išsiskiriantis vertikalus elementas (bokštas) arba plastiškas tūris (ansamblis) (Jurkštas 1994). V. Jurkšto apibūdintos aukščiausios kategorijos urbanistinès kompozicijos reikšmingumas paprastai yra grindžiamas išsiskiriančių kompozicinès struktūros elementų (dominančių) ir likusių elementų (fono) kontrastišku sugretinimu, kuris daro emocini poveikį žmogui.

\subsubsection{Space syntax metodika}

Šveicaru matematikas ir fizikas Leonhardas Euleris (1707-1783) buvo pirmas, spręsdamas su žmonių judejjimu mieste susijusi uždavini, panaudojęs grafą, iš matematinių abstrakcijų - viršūnių ir briaunų - sudarytą modeli (Ostwald 2011). Nagrinėdamas septynių Karaliaučiaus tiltų problemą jis nustatè, kad neįmanoma sudaryti tokio maršruto, kad kiekvieną tiltą galima būtų pereiti tik vieną kartą ir grižti ị pradinị tašką.

Vienas iš žinomiausių XX a. darbų grafų teorijos srityje yra amerikiečių matematiko Franko Harary (1969). Grafu teorijos suklestejimą XX a. ir jos taikymą architektūros srityje savo straipsnyje atskleidè Michaelas J. Ostwaldas (2011), kaip vieną iš svarbiausių space syntax metodikos ypatumų įvardijęs pastebètas galimybes panaudoti grafą architektūrinès ir urbanistinès erdvės daliu jungiamumui ir susisiekiamumui nagrinèti, remiantis grafų teorija išplètotą teorini modeli bei jo pritaikymą praktinejje veikloje. Šiame moksliniame darbe pristatoma urbanistinio projektavimo srityje taikoma space syntax teorijos ir metodikos dalis, kurios dèmesio centre - urbanistinès erdvès konfigūracija, neįtraukiant privačių erdvių ir pastato vidaus erdvių.

Space syntax (erdvès sintaksė) yra miesto viešujų erdvių tyrimo metodika, taikoma architektūros, urbanistinio projektavimo ir planavimo veikloje. Metodika paremta urbanistinès erdvės sandaros ir jos elementų tarpusavio ryšių geometriniu vaizdavimu ir ja siekiama atskleisti erdvès savybių ir socialinių bei

\footnotetext{
${ }^{31}$ Pasak V. Jurkšto, gatvės erdvės pobūdžio tyrimui ịtakos turi tai, iš kurio taško stebimas gatvès vaizdas. Vykdant istorinių miestų dalių tyrimus, pasirinkti šaligatviai, kuriais eina daugiau žmonių (Jurkštas 1975).
} 
ekonominių procesų mieste sąveiką. Šios metodikos teorinis pagrindas - fundamentalieji ir taikomieji erdvès sandaros ir žmonių judejjimo pobūdžio (pattern of movement) priklausomybès nuo urbanistinès erdvès konfigūracijos (spatial configuration) tyrimai, kurie yra paremti judejimo ekonomikos (movement economy) modeliu ir kurie nuo XX a. 8-ojo dešimtmečio pabaigos plètojami Billo Hillier ir kitų Londono universiteto koledžo (University College London) mokslininkų (Hillier et al. 1976; Hillier, Hanson 1984; Hillier et al. 1993; Hillier 1999; 2007; Batty 2004; Hillier, Iida 2005; Chiaradia et al. 2009b). Vienas iš metodikos kūrimo tikslų yra padèti architektams suprasti formuojamos erdvès itaką socialinei ir ekonominei veiklai, vertinant architektūrinių ir urbanistinių sprendimų poveiki, numatant gretimų kvartalų ar viso miesto urbanistinès struktūros pokyčius.

Atsižvelgiant ị urbanistinio projektavimo dabartinę sampratą, kurią savo straipsnyje atskleide Kayvanas Karimis (2012a), galima pateikti keturis kriterijus, rodančius minètos metodikos pasirinkimo aktualumą. „Pirma, projektavimo proceso metu naudojama analizès metodika turi būti paremta erdvès nagrinejjimu. $<\ldots>$ Antra, urbanistinès erdvès analizès metodika naudotina siekiant tiesiogiai sujungti erdvès naudojimo ypatumus ir žmonèms, jos naudotojams, būdingus veiksmus bei sąveikas. <...> Trečia, turi būti galimybè naudojant minètą analizès metodiką keisti masteli [t. y. nagrinèti visą miestą, miesto dali ir pereiti ị detalesni urbanistinès erdvès lygmeni]. < ..> Ketvirta, pasitelkiant urbanistinès erdvès analizès metodiką, urbanistinè sistema nagrinètina kaip visuma arba suskaidyta ị dalis" (Karimi 2012a: 304).

Pasiekiamumas apibrěžiamas kaip patogumas pasiekti tam tikrą vietą ir gali būti apibūdinamas vertinant pèsčiujų bei automobilių transporto judèjimą, atstumą pėsčiomis iki viešojo transporto stotelių ir būtiniausių paslaugų, kelionès laiką arba gyventojų pasiskirstymą tam tikroje teritorijoje (Cowan 2005). Kaip vieni iš svarbiausių pasiekiamumo vertinimo kriterijų ịvardijamas laikas, sugaištas norint pasiekti kasdienes paslaugas ir epizodiškai lankomus objektus, ir tam reikalingos išlaidos. Urbanistinès struktūros funkcionavimo efektyvumą siūloma ịvertinti analizuojant ne tik kelionès išlaidas, tačiau ir kainą, kurią gyventojai moka už susisiekimo infrastruktūros plètojimą, viešojo transporto eksploatavimą, lengvojo automobilio išlaikymą, nuostolius dẻl kelionèms sugaišto laiko ir pan. (Juškevičius, Valeika 2007). Visi išvardinti pasiekiamumo matavimo būdai nèra tinkami nuo viso miesto struktūros pereinant $\mathfrak{i}$ detalesnị urbanistinès erdvės lygmeni, siekiant pagrịsti konkrečios gatvès atkarpos tarp sankryžų galimybes būti kelionès tikslu arba maršruto dalimi. Space syntax nuo kitụ metodiku skiriasi tuo, kad pasiekiamumas matuojamas naudojant geometrini gatvių modelị ir vertinant mažiausio posūkio kampo (least angle) tarp dviejų gatvès 
atkarpu reikšmes ${ }^{32}$ (Batty 2009). Šiame moksliniame darbe remiamasi prielaida, kad taikant space syntax metodiką gauti gatvès atkarpų pasiekiamumo rodikliai ir nustatyti kelionių maršrutai atspindi žmonių judejjimą mieste, t. y. žmonių srautus ir kelius, kuriais einama ar važiuojama norint pasiekti tam tikrus objektus mieste.

Viešujų erdvių pasiekiamumo modelis paprastai yra kuriamas miesto topografiniame plane brěžiant ašines linijas - nagrinejjamos teritorijos viešąsias erdves kertančias vizualines (arba netrukdomo judejimo) ašis. Vietoje ašinių linijų plano (axial map) gali būti naudojamas linijinių elementų (gatvès atkarpų tarp sankryžų) planas (segment map), kuris sudaromas automatiniu būdu, supaprastinus georeferencinio pagrindo duomenų bazès (toliau - DB) ašines gatvių linijas (Turner 2007). Susikertančių ašinių linijų arba linijinių elementų modelis naudojamas apskaičiuojant viešųų erdvių pasiekiamumo vertes (spatial accessibility values), rodančias kelionès maršruto sudètingumą, t. y. keliomis linijomis reikia pasinaudoti keliaujantiesiems, norint pasiekti kiekvieną kitą plano liniją. Linija, kuri yra lengvai pasiekiama kitų linijų atžvilgiu, bus dažniau pasirenkama keliaujančiujų. Didesnè tikimybė, kad geriau pasiekiama linija bus ir kelionės tikslas (judejjimas ị objektą konkrečioje linijoje, to-movement), ir kelionés tarp kitų linijų dalis (judejimas linija, kai objektas yra kitoje linijoje, throughmovement). Viena iš linijų verčių yra vadinamoji integracija arba matematinis artimumas, t. y. kaip arti konkreti linija yra kitų linijų atžvilgiu. Taip pat nustatoma pasirinkimo verte arba matematinis pereinamumas, t. y. kiek trumpiausių maršrutų driekiasi konkrečia linija tarp kitų dviejų linijų nagrinèjamame modelyje (Hillier 2007). Integracijos verte naudojama siekiant nustatyti linijos kaip kelionés tikslo (destination) galimybes (potencialą), pasirinkimo verté linijos kaip kelionès maršruto tarp kitų linijų dalies (transition) galimybes (potencialą).

Naudojant linijinių elementų modelį, viešųjų erdvių pasiekiamumo vertės apskaičiuojamos atsižvelgiant ị nagrinejamą lygmenị ir pasirinktą pasiekiamumo spinduli. Sudètingiems urbanistinès erdvès sandaros bei jos elementų tarpusavio ryšiams pavaizduoti pasitelkiamos matematinio ir grafinio modeliavimo priemonès. Vienas iš svarbiausių urbanistinès struktūros elementų - gatvių ir kitų viešujų erdvių tinklas - pateikiamas grafiškai, naudojant raudonos ir mėlynos spalvų skalę. Tai suteikia galimybę išryškinti tarpusavyje sujungtus ịvairių lygmenų centrus ir subcentrus, kurių fone lieka gyvenamųjų kvartalų viešosios erdvès (Hillier 2009).

Taikant space syntax metodiką, sprendžiant su urbanistine kompozicija susijusius klausimus, apskaičiuotų pasiekiamumo verčių ir atskirų kompozicinès

\footnotetext{
${ }^{32}$ Moksliniais tyrimais patvirtinta prielaida, kad judėdami mieste žmonès pasirenka ne trumpiausius kelius (maršrutus), bet laikosi mažiausio posūkio kampo principo (Hillier, Iida 2005).
} 
struktūros elementų - ašių, mazgų, dominančių ir kt. - išsidèstymo tarpusavio ryšio aspektus bande atskleisti Ruth Conroy Dalton ir Sonitas Bafna (2003). Savo moksliniame darbe jie nagrinejo K. Lyncho atskiru elementų vizualiniu suvokimu paremtos teorijos bei space syntax teorijos ir metodikos derinimo galimybes ir padare išvadą, kad atskiri kompozicinès struktūros elementai ir urbanistinès erdvès struktūra tarpusavyje sąveikauja. Pasiūlyta urbanistinès erdvès struktūros geometrinius modelius naudoti vykdant su miesto įvaizdžiu susijusius tyrimus. Tai galètų palengvinti ir paspartinti minètų elementų tarpusavio ryšių nustatymą bei sumažinti natūrinių tyrimų apimtị. Christophe'as Claramunt'as ir Stephanas Winteris (2007), remdamiesi grafu teorija ir space syntax metodika, nagrinejjo K. Lyncho ìvardytu atskirų struktūros elementų, itraukiant gatvių tinklo elementus, vaidmeni (structural importance), siekdami atskleisti urbanistinès erdvès savybių ir kelionès maršruto pasirinkimo tarpusavio ryšį bei sukurti minètų elementų santykinès svarbos automatinio nustatymo priemones.

Londono universiteto koledžo mokslininkai jau yra žengę pirmuosius žingsnius link space syntax metodikos naudojimo tiriant urbanistinès struktūros formavimosi procesus (generative processes), kuriant urbanistinių projektų koncepcines dalis, susiaurinant galimų projekto variantų pasirinkimą ir taip palengvinant sprendimu prièmimą architekto kūrybos procese (Al-Sayed 2012; AlSayed et al. 2012). Kita svarbi metodikos plètojimo kryptis - matematinio modelio tyrimas, sutelkiant dėmesị ị urbanistinès erdvès konfigūracijos pobūdžio ịvertinimo būdų, ypač pasirinkimo arba matematinio pereinamumo, normalizavimą. Tai leistu palyginti ịvairaus dydžio pasaulio miestus ir įvertinti dar neatskleistus urbanistinès erdvès sandaros ir jos elementų tarpusavio ryšių ypatumus (Hillier et al. 2012). Savo straipsnyje B. Hillier paaiškino pasirinkimo (choice), vieno iš svarbiausių urbanistinès erdvès konfigūracijos pobūdžio ịvertinimo būdų, išplètojimą ${ }^{33}$, pažymėdamas, kad sukurtas viešujų erdvių tinklo struktūros elementų santykinès svarbos nagrinejjamame tinkle nustatymo būdas yra originalus (Hillier et al. 2012). Tačiau reikia paminèti, kad taikant minètą metodą ir Lintono C. Freemano (1977) pasiūlytą centrinès padèties (centrality) ịvertinimo būdą, sukurtą nagrinèti socialinius tinklus, gauti rezultatai vienodi (skiriasi skaičiavimo metodika).

Space syntax metodika taikoma nagrinejjant ịvairius urbanistinio projektavimo ir strateginio planavimo klausimus, sprendžiant urbanistinès struktūros ir jos funkcionavimo problemas: pėsčiųų judejimo, užstatymo tankio, prekybos ir

\footnotetext{
${ }^{33}$ Pasirinkimo (choice), urbanistinès erdvès konfigūracijos pobūdžio įvertinimo būdo, galimybès pirmą kartą pristatytos straipsnyje (Hillier et al. 1987), praejjus trejiems metams po integracijos (integration) galimybes atskleidusios monografijos (Hillier, Hanson 1984) išleidimo. Platesnès metodo panaudojimo galimybès atsivèrè ịvedus mažiausio posūkio kampo linijinių elementų analizès kriterijų (Hillier, Iida 2005).
} 
paslaugų funkcijų susitelkimo bei sąryšio su gyvenamaja funkcija ${ }^{34}$. Šio mokslinio darbo antrajame skyriuje, remiantis atlikto viešųų erdvių pasiekiamumo tyrimo duomenimis, siekiama atskleisti kai kurias su Vilniaus miesto lokaliu centrų vieta ir vaidmeniu susijusias problemas bei dèl nagrinejjamų centrų plano neužbaigtumo ir (arba) neefektyvumo kylančius prieštaringumus. Pavyzdžiai, kuriais remtasi planuojant tyrimus, yra naujaisiais miestais vadinamų urbanistinių projektų, XX a. antroje puseje ịgyvendintų Jungtinejje Karalystejje, prieštaringumų tyrimas (Karimi et al. 2009) ir Londono lokalių centrų urbanistinès erdvès savybių ir socialinių bei ekonominių procesų mieste sąveikos tyrimas (Hillier 2009).

\subsection{Pirmojo skyriaus išvados}

1. Formuojant daugiafunkcius centrus didžiausias dèmesys turi būti skiriamas jų gyvybingumo ir galimybių išlikti užtikrinimui: reikètų gerinti centro pasiekiamumą pésčiomis ir viešuoju transportu, mažinant priverstines keliones lengvuoju automobiliu. Šios savybès leidžia pritraukti investicijų plètrai, renovacijai ir prisitaikyti prie kintančių visuomenės poreikių.

2. Lietuvos didmiesčių lokalūs centrai nèra patrauklūs žmonėms, kurie teikia pirmenybę lengvajam automobiliui ir kurių kasdienius poreikius tenkina greta aukštų kategorijų magistralinių gatvių įkurti privatūs prekybos ir pramogų kompleksai. Siekiant padidinti lokalių centrų gyvybingumą ir konkurencingumą, lyginant su privačiais prekybos ir pramogų kompleksais, turètų būti taikomos šios priemonès: užtikrinamas pakankamas centrų užstatymo tankis, galimybès pritaikyti pastatus naujoms funkcijoms, didinama teikiamų paslaugų ịvairovè ir gerinama urbanistinès aplinkos kokybè.

3. Remiantis V. Jurkšto sudaryta tyrimų metodika ir Lietuvos miestų kompozicinę struktūrą tyrusių mokslininkų metodinèmis rekomendacijomis, gatvių ir kitų viešujų erdvių tinklo ypatumų analizè gali padèti atskleisti urbanistinès erdvès savybių svarbą ir ịvertinti atskirų elementų vaidmenị. Tam yra tikslinga naudotis naujausių funkcinès struktūros tyrimo me-

\footnotetext{
34 Viešujų erdvių pasiekiamumo modeliai sukurti ir taikomi sprendžiant įvairių miestų urbanistinès struktūros bei jos funkcionavimo problemas, pavyzdžiui, Londono, Miuncheno, Barselonos, taip pat kaimyninių Rygos ir Talino. Galima paminèti ir daugiau miestų, kadangi space syntax metodika žinoma ir plačiai taikoma visame pasaulyje. Siekiama sukurti metodiką, leidžiančią palyginti įvairaus dydžio pasaulio miestus, jų gatvių tinklo ypatumus (Hillier et al. 2012).
} 
todu galimybėmis. Space syntax metodika taikoma nagrinèjant įvairius urbanistinio projektavimo ir strateginio planavimo klausimus, sprendžiant urbanistinès struktūros ir jos funkcionavimo problemas. Palyginti su kitais pasiekiamumo matavimo būdais, space syntax metodika išsiskiria tuo, kad naudojamas geometrinis gatviu modelis ir vertinamos mažiausio posūkio kampo tarp dviejų gatvès atkarpų reikšmès. Naudojant tą patị viso miesto modelị galima pereiti ị detalesnị urbanistinès erdvés lygmeni, siekiant pagrịsti konkrečios gatvès atkarpos tarp sankryžų galimybes būti kelionès tikslu arba maršruto dalimi. 



\section{2}

\section{Lokalių didmiesčio centru urbanistinès struktūros tyrimai}

Antrajame skyriuje tiriama lokalių didmiesčio centrų urbanistinė struktūra: nustatoma Vilniaus miesto lokalių centrų vieta ir apibūdinamas jų vaidmuo viso miesto mastu (pirmasis tyrimų etapas) bei pereinama prie išsamaus trijų lokalių centrų, esančiŭ Vilniaus miesto šiaurès vakarų dalyje, nagrinèjimo (antrasis tyrimų etapas). Siame skyriuje pateikiami tyrimų rezultatai buvo publikuoti dviejuose straipsniuose: mokslo žurnale „Urbanistika ir architektūra“ ir Aštuntojo tarptautinio space syntax simpoziumo straipsnių rinkinyje (Bučys 2010; 2012).

\subsection{Lokalių centrų vieta ir vaidmuo hierarchinèje didmiesčio centrų sistemoje}

Analizuojant prekybos ir paslaugu imoniu išsidèstymą savaime susiformavusiuose didmiesčiuose, galima pastebėti, kad lokalių centrų vieta yra glaudžiai susijusi su žmonių judejjimu ir ypač tais viešujų erdvių tinklo elementais, kuriuose susitelkę didžiausi žmonių srautai. Problema yra ta, kad, planuojant lokalius centrus pertvarkomose ar naujai formuojamose miestų dalyse, parenkant prekybos ir paslaugų objektų vietas, ne visada yra atsižvelgiama ị esamą padètị (pa- 
vyzdžiui, gatvių tinklo ypatumus), atsisakoma išsamių tyrimų ir pasikliaujama intuicija, meniniu sprendimu bei subjektyvia ekspertu nuomone. Vykdydamas šiame skyriuje aprašytą tyrimą autorius nori parodyti, kad pasitelkus technines priemones, t. y. matematiniams skaičiavimams naudojant urbanistinès erdvès analizès programinę įrangą ${ }^{35}$, galima preliminariai ịvertinti vietos potencialą, atspindinti prognozuojamą žmonių srautų pasiskirstymą gatvių tinkle ${ }^{36}$.

Pirmojo tyrimų etapo tikslas yra naudojant geometrinio miesto modelio ypatumus ịvertinantị pasiekiamumo matavimo būdą atskleisti urbanistinès erdvès savybių svarbą ir įtaką lokalių centrų formavimuisi strategiškai svarbiose vietose, ju gyvybingumui ir galimybėms plètotis. Kaip jau minèta 1.3 .3 skyrelyje, pasiekiamumo matavimas naudojant geometrini gatvių modeli ir vertinant mažiausio posūkio kampo tarp dviejų gatvès atkarpų reikšmes buvo pasirinktas todèl, kad šis būdas yra tinkamas siekiant nustatyti ne tik tam tikros miesto dalies, bet ir pasirinktu gatvès atkarpų galimybes (potencialą). Kai kuriais atvejais dèl nagrinejjamo gatvių tinklo ypatumų, dominuojančių elementų funkcinès svarbos ir ju ịtakos žmogaus orientavimosi urbanistinejje erdvejje galimybèms dažniau pasirenkamas keliaujančiujuc gatves galima nustatyti ir netaikant matematinio modeliavimo priemonių. Globaliu lygmeniu geriausiai pasiekiamomis galima ịvardyti tiesiausias ir ilgiausias gatvių atkarpas, nagrinejjamo tinklo elementus, kurie yra užmiesčio kelių tęsiniai (pavyzdžiui, Ukmergès gatvé Vilniuje). Tačiau problema yra ta, kad ignoruojant modernistinio (laisvojo) planavimo sprendimų sukeltas pasekmes ir neužtikrinant minètų viso miesto mastu ilgiausių gatvių pasiekiamumo lokaliu lygmeniu, nèra išnaudojamos gretimų kvartalų plètros galimybès. Kaip tik dèl to sovietiniais metais suformuotų gyvenamujų rajonų centrų tarpusavio jungiamumą ir jų ryšius su ilgiausiomis gatvèmis - i pagrindinị (istorinị) miesto centrą vedančiais užmiesčio kelių tęsiniais - yra tikslinga tirti pasitelkus jau žinomus tyrimo metodus ir gautus rezultatus palyginti su kitų tyrèjų rezultatais.

Vilniaus urbanistinè struktūra buvo tiriama taikant space syntax metodiką ${ }^{37}$. Vilniaus miesto modeliui ir schemoms rengti naudota Lietuvos Respublikos teritorijos georeferencinio pagrindo duomenų bazés informacija, apdorota MapInfo programa ir Londono universiteto koledžo mokslininkų sukurta Depthmap programine ịranga.

${ }^{35}$ Depthmap [žiūrèta 201206 07]. Prieiga per internetą: http://www.spacesyntax.net/ software/ucl-depthmap. Depthmap programine ịranga disertacijos rengimo laikotarpiu buvo laisvai prieinama internete.

${ }^{36}$ Tyrimų rezultatai rodo, kad viešujų erdvių tinklo struktūra bei pėsčiųjų ir automobilių srautu pasiskirstymas minètame tinkle tarpusavyje siejasi (Penn et al. 1998).

${ }^{37}$ Tyrimas vykdytas stažuotės ịmoneje „Space Syntax Limited“ metu, 2010 m. vasariogegužès mèn. Stažuotei ir moksliniams tyrimams gauta parama pagal Mokymosi visą gyvenimą / Erasmus programą. 
Planuojant pirmaji tyrimų etapą buvo keliami šie uždaviniai: 1) parengti Vilniaus miesto viešujų erdvių pasiekiamumo modelį; 2) nustatyti viešujų erdvių pasiekiamumo vertes, pateikti modeli grafiškai, naudojant raudonos bei mèlynos spalvų skalę (taikant îvairius pasiekiamumo spindulius) ir pasirinkti variantus, geriausiai atspindinčius analizès rezultatus; 3) išnagrinèti Vilniaus miesto viešujų erdvių tinklo ypatumus, ịvertinti esamus centrus ir juos supantị kontekstą bei nustatyti galimas vietas naujiems lokaliems centrams formuoti(s).

Viena iš svarbiausių tyrimo naujovių yra ta, kad siekta nagrinèti ne atskirų centrų, kurie dažniausiai jungiami i per daug supaprastintą (oversimplified) miesto modelį, urbanistinès erdvès savybes, bet atskleisti lokalių centrų tarpusavio sąveiką, t. y. jų vietą ir vaidmenị miesto viešujų erdvių sistemoje. Lokalių centrų vietos svarbą galima paaiškinti remiantis esminiu space syntax metodikos požiūriu į miestą, kai teikiama pirmenybè viešujų erdvių tinklui ir jo formavimosi procesui, kuris yra vienas iš svarbiausių veiksnių, lemiančių miesto išskirtinumą. Kadangi žmonių judējimo srautų susitelkimas priklauso nuo susiklosčiusio gatvių tinklo, tai lemia ir funkcijų pasiskirstymą mieste. Aktyviai veiklai, pavyzdžiui, prekybai, yra ypač svarbi vieta, kurioje vyktų intensyvus judejimas, o panašios veiklos telkiniai sudaro sujungtus įvairiu lygmenų centrus ir subcentrus. Pastarųų fone lieka ramesnès viešosios erdvès, kuriose vyrauja gyvenamoji funkcija.

Tačiau reikia pabrèžti, kad tyrimo rezultatai neturètų būti absoliutinami, nes dèmesys yra sutelkiamas ị lokalių centrų galimybes (potencialą), priklausančias nuo viešujų erdvių konfigūracijos (išsidèstymo plane ir tarpusavio ryšių) ir natūralaus, nepaveikto šalutinių veiksnių, judejjimo (natural movement) centrą kertančiomis gatvėmis ir pésčiujų takais. Kiti svarbūs aspektai, kurie neįtraukti planuojant pirmaji tyrimų etapą ir nèra nagrinejami, tai gyventojų skaičius (tankis), funkciju ivairové ir pasiskirstymas, centro kaip traukos objekto galimybės (potencialas) ir kiti socialiniai bei ekonominiai veiksniai.

Nagrinejjant Vilniaus urbanistinès struktūros modeli (kuriant minètą modeli naudotas linijinių elementų planas, žr. 2.1 pav.) buvo remiamasi tyrimais (Hillier 2009), kuriais siekiama ịrodyti, kad centrų formavimąsi lemia lokalių ir globalių urbanistinès erdvès savybiu sutapimas (coincidence). Tikrinant šią prielaidą buvo taikyti ịvairūs pasiekiamumo spinduliai: 400, 800, 1200, 1600, 2000, $5000 \mathrm{~m}$ ir begalybè - nuo lokalaus iki globalaus lygmens.

Pasirinkimo arba matematinio pereinamumo skaičiavimais pagristos Vilniaus miesto schemos objektyviai apibūdina nagrinejjamą dalyką ${ }^{38}$. Pirmosios dvi

\footnotetext{
${ }^{38}$ Kelionès maršruto nustatymas, ịvertinant mažiausią posūkio kampą, yra Depthmap programos numatytoji parinktis (Hillier et al. 2012). Minètas maršruto pasirinkimo būdas tiksliausiai atspindi prognozuojamą žmonių srautų pasiskirstymą gatvių tinkle (Hillier, Iida 2005). Iki ịvedant mažiausio posūkio kampo linijinių elementų analizès kriterijų, siekiant gauti žmonių judèjimą mieste atspindinčius rezultatus, buvo
} 
vaizduoja viešujų erdvių pasiekiamumą $800 \mathrm{~m}$ ir $2000 \mathrm{~m}$ spinduliu (2.2 ir 2.3 pav.), trečioji - bet kokiu (neapibrèžtu) spinduliu, vadinamuoju radius $n$, kur $\mathrm{n}-$ begalybè (2.4 pav.).

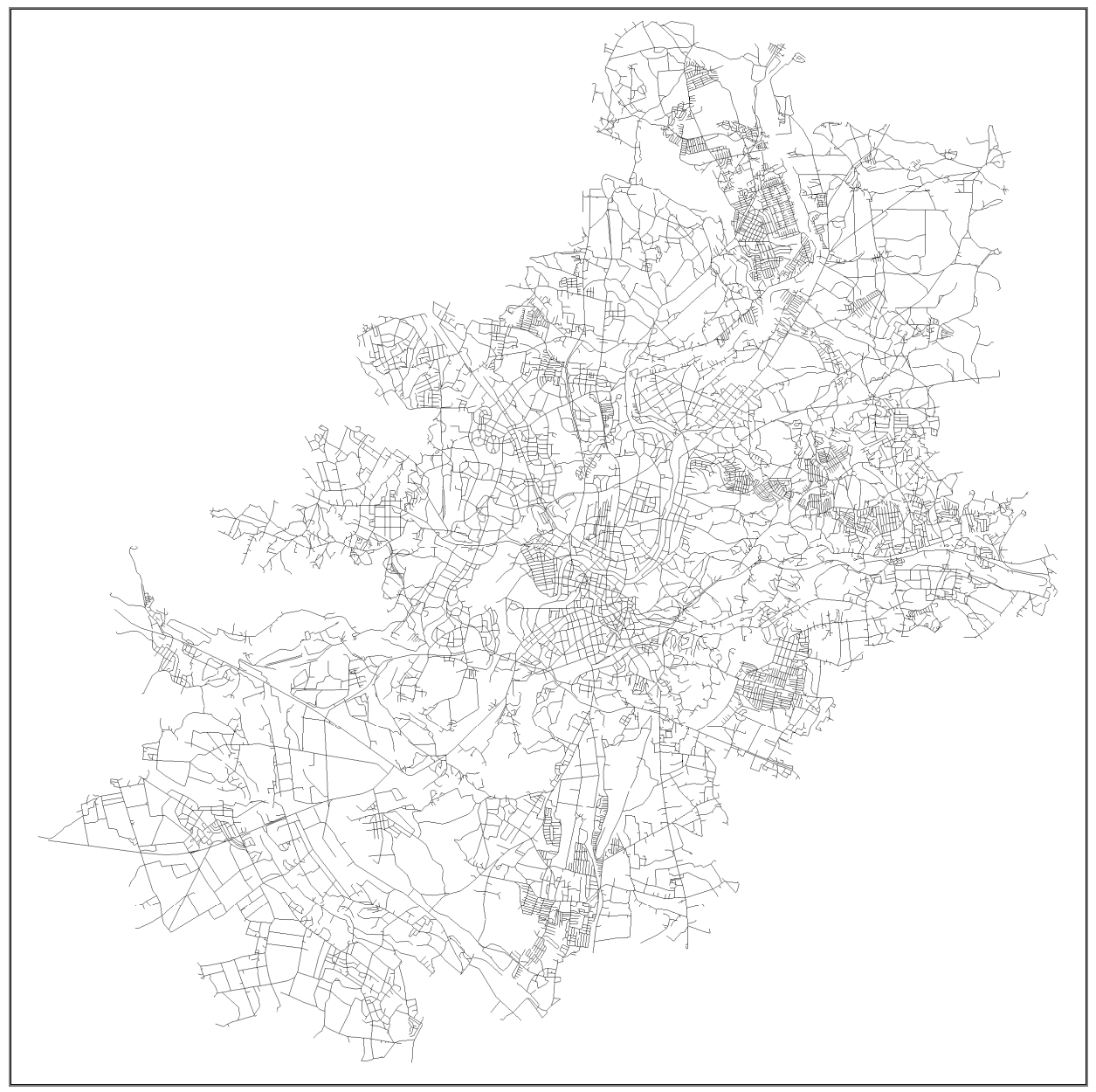

2.1 pav. Linijinių elementų planas (be priskirtų viešųų erdvių pasiekiamumo verčių), naudojamas kuriant Vilniaus miesto viešujų erdvių pasiekiamumo modeli

Fig. 2.1. Segment map (without assigned spatial accessibility values) that is used to create a spatial accessibility model of Vilnius city

naudojamos integracijos arba matematinio artimumo (Hillier, Hanson 1984; Sabidussi 1966) skaičiavimais pagrịstos schemos. 


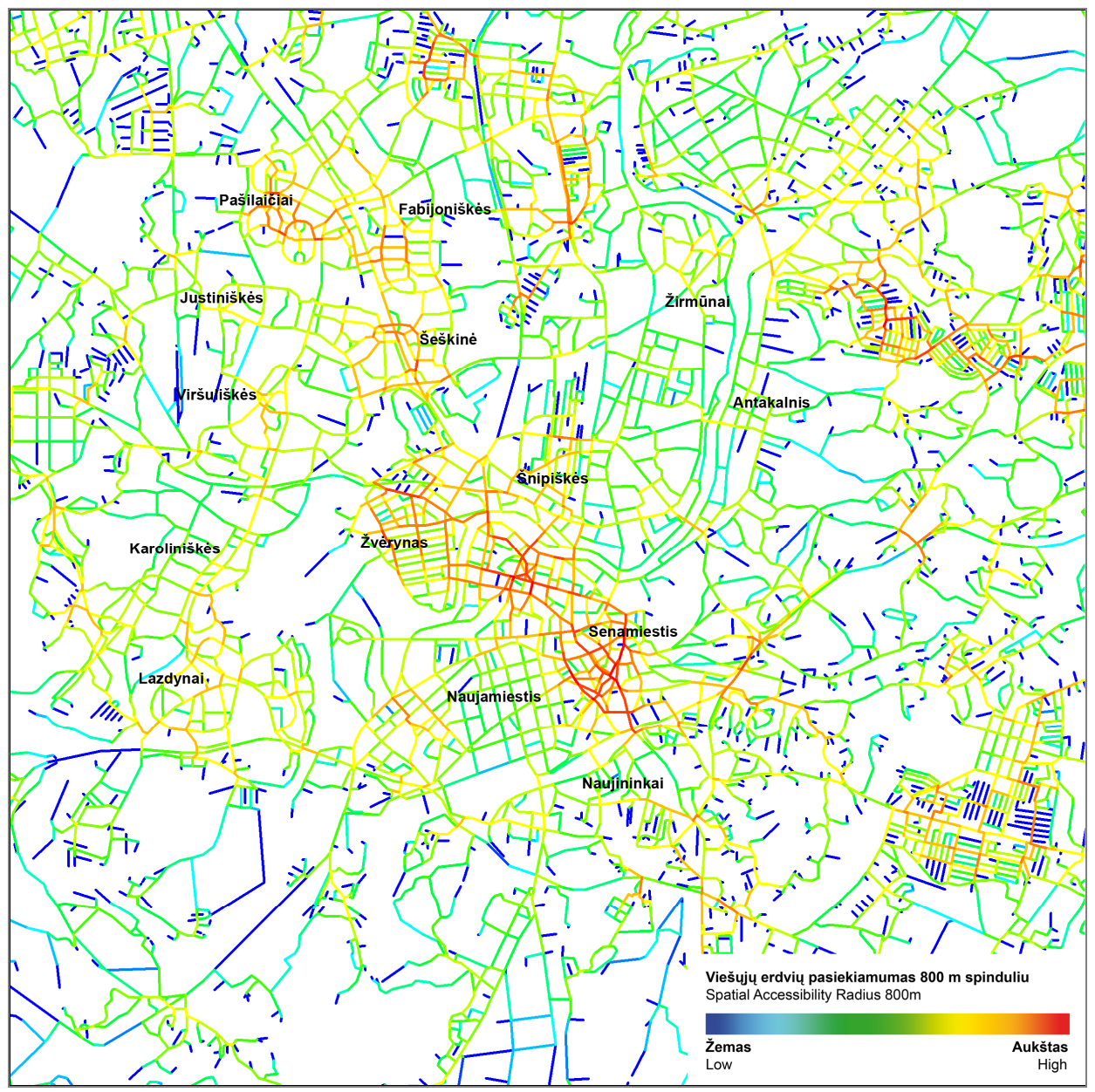

2.2 pav. Vilniaus miesto viešujų erdvių pasiekiamumo $800 \mathrm{~m}$ spinduliu schema (pasirinkimas, ịvertinant mažiausią posūkio kampą)

Fig. 2.2. Spatial accessibility model of Vilnius city at an $800 \mathrm{~m}$ radius (throughmovement; segment angular choice) 


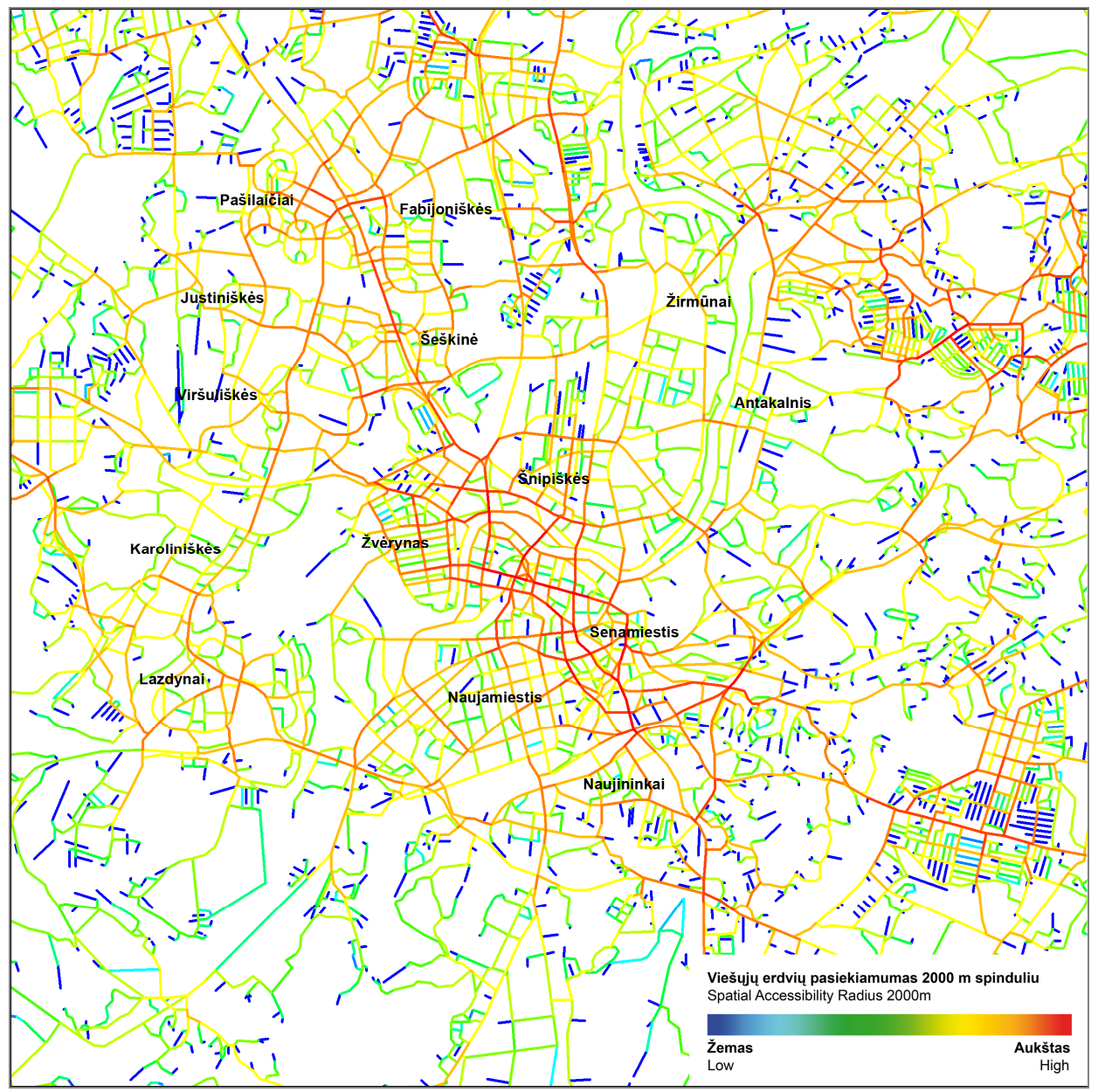

2.3 pav. Vilniaus miesto viešųų erdvių pasiekiamumo $2000 \mathrm{~m}$ spinduliu schema (pasirinkimas, įvertinant mažiausią posūkio kampą)

Fig. 2.3. Spatial accessibility model of Vilnius city at a 2000 m radius (throughmovement; segment angular choice)

Kelionės iki $800 \mathrm{~m}$ atstumu, kurių trukmė iki 10 minučių, yra glaudžiai susijusios su miesto lokaliais centrais ir žmonių judejjimu juose - tą rodo tyrimai, kuriuos atliekant buvo nustatytas viešųų erdvių pasiekiamumo verčių ir pėsčiųjų skaičiaus tam tikrose gatvių atkarpose atitikimas (Hillier et al. 1993). Iki $2000 \mathrm{~m}$ atstumu nutolusius centrus patogu pasiekti dviračiu arba viešuoju transportu. Viešujų erdvių pasiekiamumo $800 \mathrm{~m}$ spinduliu schemoje (2.2 pav.) išryškinti ìvairių lygmenų lokalūs centrai ir galimos vietos naujiems centrams formuotis 
(raudonos ir geltonos spalvų skalè). Likusią didesniąją schemos dalị užima gatvių tinklas, kuriame vyrauja gyvenamoji funkcija (žalios ir mèlynos spalvų skalè). Antrojoje schemoje (2.3 pav.) išryškejja likusieji centrai, kurių užuomazgos pastebimos pasiekiamumo $800 \mathrm{~m}$ spinduliu schemoje.

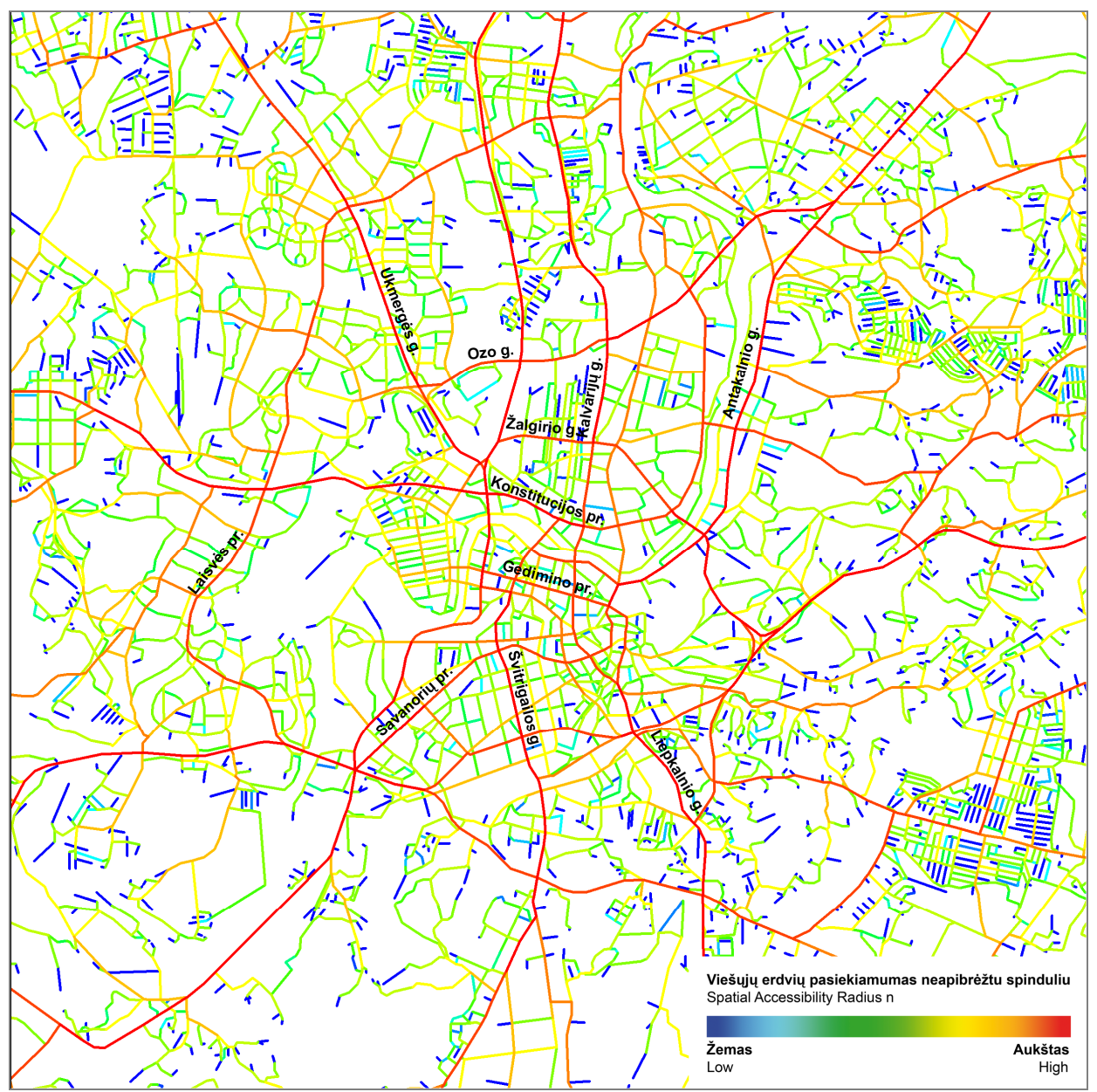

2.4 pav. Vilniaus miesto viešujų erdvių pasiekiamumo neapibrèžtu spinduliu schema (pasirinkimas, îvertinant mažiausią posūkio kampą)

Fig. 2.4. Spatial accessibility model of Vilnius city at a radius $n$ (through-movement; segment angular choice) 
Viešujų erdvių pasiekiamumo neapibrěžtu spinduliu (radius $n$ ) schema (2.4 pav.) vaizduoja susisiekimo linijų, kuriose yra susitelkę aktyvios socialinès ir ekonominès veiklos židiniai, hierarchiją. Šioje strateginio lygmens analizės schemoje išryškintos svarbiausios (viso miesto mastu) gatvès, kuriomis galima kirsti miestą. Schemoje pakankamai tiksliai atspindèta esama būklè, išskyrus kai kuriuos nukrypimus miesto pakraščiuose $\mathrm{e}^{39}$.

Vilniaus centrinèje dalyje ${ }^{40}$ esančių lokalių centrų potencialas priklauso nuo jų ryšių su Pilies gatve ir Gedimino prospektu, svarbiausiomis miesto viešosiomis erdvėmis, kurių pasiekiamumo vertès yra aukščiausios. Pagrindinè naujojo miesto centro dešiniajame Neries krante viešoji erdvè, Konstitucijos prospektas, naudojama atvykstančiujų i miestą iš vakarų ir šiaurès vakarų pusès, tačiau pasiekiamumo lokaliu lygmeniu atžvilgiu Baltojo ir Žaliojo tilto ašys, kaip jungtys su istoriniu centru, yra svarbesnès. I šiaurę nuo Konstitucijos prospekto besidriekiančių lygiagrečių Giedraičiu ir Kalvarijų gatvių vaidmuo skirtingas: Giedraičių gatvès reikšmè yra lokali, Kalvarijų gatvè yra svarbi šiaurès-pietų susisiekimo arterija (viso miesto mastu). Kernavès gatvès, trečiosios lygiagretès, reikšmè mažesnè. Tačiau ateityje taptų aktuali jos jungtis su Žalgirio gatve, kurioje pastatyti ir suplanuoti nauji komercinès paskirties objektai.

Žalgirio gatvès urbanistinès erdvès konfigūracija pasižymi savybe, kuri išskiria šią svarbią vakarų-rytų jungtị iš supančio konteksto. Lokalių centrų savitumas, pastebètas nagrinejjant urbanistinès erdvès konfigūraciją (Hillier 1999; Chiaradia et al. 2009b), yra tankesnis viešujų erdvių tinklas, ši ypatybė dar vadinama pralaidumu arba gatvių tinklo „susisiekiamumu“. Minèta ypatybė rodo galimybes pereiti, kirsti centrą pasirenkant ịvairius maršrutus. Tiriant Vilniaus viešujjų erdvių tinklą, nepastebèta ryškių pasikeitimų, dèl kurių esami lokalūs centrai išsiskirtu iš juos supančio konteksto. Vilniaus centrinèje dalyje tankiausias yra senamiesčio viešujų erdvių tinklas. Aukštesnis pralaidumo rodiklis (priklausantis nuo gatvių tinklo smulkumo) yra Žvėryne, abipus Sèlių gatvès, ypač prie sankryžos su Kęstučio gatve. Šis lokalus centras turi galimybes plètotis suformavus Sèlių gatvès išklotinę (užstatymą) buvusiame viešojo transporto mazge. Lokaliu lygmeniu ši vieta yra geriau pasiekiama negu prie Saltoniškių ir T. Narbuto gatvių sankryžos esantis prekybos ir pramogų kompleksas, kurį nuo Žvèryno rajono pietinès dalies skiria magistralinè gatvè.

\footnotetext{
${ }^{39}$ Vienas iš space syntax metodikos trūkumų - vadinamasis pakraščio efektas (edge effect), kai nagrinèjamos teritorijos pakraščiai vaizduojami netiksliai. Norint išvengti šios neatitikties esamai būklei, reikètų išplèsti modelị prijungiant apie $2 \mathrm{~km}$ pločio priemiesčio juostą.

${ }^{40}$ Centrinę, vidurinę ir periferinę Vilniaus miesto dalis apibūdina jų funkcionavimo ypatumai ir savitumas (Juškevičius, Valeika 2007).
} 
Vidurineje dalyje sovietiniais metais suformuotu gyvenamujų rajonų ypatybè - retas gatvių tinklas ir pakankamai tankus pésčiųų takų, vedančių i lokalų centrą, tinklas. Kita aktuali problema nustatant tinkamiausias vietas lokaliems centrams plètoti - viešujų ir privačių erdvių susipynimas. Pavyzdžiui, Vilniaus vakarinejje dalyje vienintelè globaliu mastu reikšminga jungtis yra Laisvès prospektas, kuriame sutelktas automobilių srautas, o pėstieji dažniausiai juda šalutinèmis gatvėmis ir pésčiujų takais kvartalų viduje. Tai turi įtakos pasiekiamumo rodikliams. Nors gyvenamuosiuose rajonuose kasdienius poreikius tenkinantys objektai išdèstyti taip, kad būtų pasiekiami pèsčiomis per $10 \mathrm{~min}$., abipus Laisvès prospekto ir Ateities gatvès esantys lokalūs centrai išryškejjo tik taikant $1200 \mathrm{~m}$ ir didesnius pasiekiamumo spindulius. Panaši padètis yra Šiaurès miestelyje ir Žirmūnuose. Nors ir keista, bet Antakalnio gatvejje taip pat sunku išskirti vietas, kurios būtų patogiai pasiekiamos taikant $800 \mathrm{~m}$ spindulị. Tačiau galima pastebèti, kad Žirmūnų ir Šilo tiltų prieigos turètų būti dažniausiai pasirenkamos keliaujančiujų. Dar viena vieta, išsiskirianti geresniu pasiekiamumu ir tinkama naujam centrui plètoti, yra viešojo transporto mazgas Nemenčinès plento pradžioje. Neiškilo sunkumų nustatant Savanorių prospekto (atkarpoje tarp Žemaitès ir Gerosios Vilties gatvių), Baltupių, Jeruzalès (Kalvarijų gatvès atkarpose) lokalius centrus, kurie yra tinkamose vietose ir turi galimybes plètotis.

Galimos vietos naujiems lokaliems centrams formuoti yra prie svarbių magistralinių gatvių esančios pramonès ir kitos neefektyviai naudojamos teritorijos, kurias ketinama pertvarkyti i daugiafunkcius gyvenamosios ir komercinès paskirties kvartalus (pavyzdžiui, Savanorių prospekto žiedas ir Zarasų bei Subačiaus gatvių transporto mazgas).

Centrai efektyviai funkcionuoja tik išsidèstę tam tikrais atstumais vienas nuo kito. Jų tarpusavio sąveika yra svarbus aspektas, vertinant konkretaus centro galimybes plètotis. Viena iš priežasčių, kodèl lokalus centras nesiplečia ir jo itaka mažeja, yra ta, kad greta esantis kitas aktyvus urbanistinis mazgas pritraukia dali potencialių centro lankytojų. Skirtingo lygmens centrų sąveiką Vilniaus mieste galima iliustruoti vidurinejje dalyje, abipus Ukmergès gatvès, esančių lokalių centrų pavyzdžiais.

Šeškinès lokalaus centro gyvybingumą ir patrauklumą lankytojams galima būtų paaiškinti tuo, kad jo integracijos ir pasirinkimo - galimybès būti kelionès tikslu arba maršruto dalimi - rodikliai yra aukšti, t. y. jo vieta yra svarbi ir viso miesto mastu, ir aplink esančių viešujų erdvių kontekste. Abipus magistralinės gatvès išplètotas lokalus centras yra gerai pasiekiamas pésčiomis, tačiau dali Šeškinès gyventojų, ypač turinčių lengvaji automobilị ir retai besinaudojančių viešuoju transportu, pritraukia Ozo gatvèje išsidèstę prekybos ir pramogų kompleksai. Viešujų erdvių pasiekiamumo $800 \mathrm{~m}$ spinduliu analizès schemoje galima pastebėti labai silpnus Ozo gatvèje išsidėsčiusių prekybos ir pramogų 
kompleksų ryšius su juos supančiu kontekstu. Nors žvelgiant globaliu mastu šie objektai yra strategiškai svarbiose vietose, lokaliame kontekste jungiamumo su aplink esančių gyvenamųų kvartalų viešųjų erdvių tinklu rodiklis yra žemas.

Fabijoniškių rajone, kur šiuo metu yra susiformavę keletas lokalių centrų (kai kurie tik pradejję formuotis), galima pastebèti suplanuotų funkcijų ir esamos struktūros galimybių neatitikimą. Rajono viduryje, tarp Fabijoniškių ir S. Stanevičiaus gatvių, esančio centro pasiekiamumo rodikliai aukščiausi taikant 400 ir $800 \mathrm{~m}$ spindulius. Didinant pasiekiamumo spinduli, nagrinejjamo centro reikšmé tolygiai mažèjo, kol visiškai sumenko taikant neapibrěžtą spinduli. Tai yra viena iš svarbiausių priežasčių, kodèl pastaruoju metu Ukmergès ir S. Stanevičiaus gatvèse susiformavo nauji lokalūs centrai, kurie yra geriau pasiekiami viso miesto mastu. Panašūs lokalių centrų vaidmens pokyčiai vyko Pašilaičiuose, kur šiuo metu dauguma prekybos ir paslaugų įmonių yra susitelkę prie Ukmergès gatvès ir Laisvès prospekto sankirtos.

Periferinejje dalyje esančių viešųjų erdvių pasiekiamumo rodikliai yra netikslūs dèl vadinamojo pakraščio efekto (edge effect), tačiau galima preliminariai ivertinti ir išskirti kai kurias potencialias vietas lokaliems centrams formuotis. Tai Pilaite (vieta turi būti tikslinama atsižvelgiant ì gyvenamuju kvartalų plètrą), Balsiai (Žaliụų Ežerų gatvès atkarpoje), Liepkalnis (Liepkalnio gatveje ir Minsko plento pradžioje). Naujosios Vilnios, Grigiškių ir kitų nutolusių lokalių centrų plètros galimybès priklausytų nuo urbanistinès struktūros pokyčių lokaliame kontekste.

Reikètų atkreipti dèmesị i mieste esančias sodininkų bendrijų teritorijas, kurios savaime virsta individualių gyvenamujų namų kvartalais. Dèl tankaus gatvių tinklo, kurių pralaidumo (,susisiekiamumo“) rodikliai yra netgi per aukšti, viešujų erdvių pasiekiamumo $800 \mathrm{~m}$ spinduliu schemoje išryškintos galimos vietos lokaliems centrams formuotis, tačiau dèl mažo gyventojų tankio pasiteisintų tik šalia pagrindinių gatvių ịsikūrę prekybos ir paslaugų objektų telkiniai, tenkinantys kasdienius gyventojų poreikius.

Sukurtas Vilniaus miesto modelis ir gauti rezultatai suteikia galimybę tęsti tyrimą miesto dalies ir lokalų centrą sudarančių kvartalų lygmeniu. Tiksliau apibūdinti Vilniaus miesto centrų sistemos esamą būklę padètų išsamūs empiriniai žmonių judejjimo, urbanistinès struktūros funkcionavimo tyrimai ir jų rezultatų sugretinimas su parengtu modeliu. Taip pat urbanistinès analizès metu gauti duomenys gali būti naudojami vertinant miesto dalių plètros koncepcijas, esamos urbanistinès struktūros tobulinimo sprendimus, pavyzdžiui, nustatant naujas jungtis tarp lokalių centrų ir juos supančių gyvenamujų kvartalų. 


\subsection{Funkcinių ir kompozicinių urbanistinès struktūros analizès aspektų sujungimas}

Antrojo tyrimų etapo tikslas yra išnagrinėti lokalių didmiesčio centrų urbanistinę struktūrą miesto dalies ir kvartalų grupès lygmeniu.

Pasirenkant antrajame tyrimų etape taikomus metodus ir siūlant jų tobulinimo būdus remtasi V. Jurkšto sudaryta urbanistinès kompozicijos ir jos vizualinio suvokimo tyrimų metodika (Jurkštas 1975; 1977; 1994) ir A. Miškinio vadovaujamos autorių grupès metodinèmis rekomendacijomis, parengtomis vykdant Lietuvos miestų kompozicinės struktūros tyrimus (Lietuvos... 2005). Svarbiausias urbanistinès struktūros tyrimų metodikos tobulinimo uždavinys yra minètų autorių moksliniuose darbuose kelto tikslo - taikant menines priemones pagerinti bendrą miesto ar jo dalies vaizdą - papildymas naujausių funkcinès struktūros tyrimo metodų galimybèmis ir, ieškant bendrų sąlyčio tašku, veiksmingos, efektyvios urbanistinès struktūros formavimo principų atskleidimas.

Buvo keliami šie pagrindiniai antrojo tyrimų etapo uždaviniai: 1) naudojant geometrinị Vilniaus miesto modelị, išnagrinèti lokalių centrų funkcinę struktūrą; 2) naudojant natūrinio tyrimo metu surinktus duomenis, išnagrinèti lokalių centrų kompozicinę struktūrą; 3) suvedant gautus funkcinès ir kompozicinès struktūrų tyrimų rezultatus, atskleisti lokalių centrų, esamų ir suplanuotų funkcijų ir miesto plano struktūros ryši. Sprendžiant pastarajį uždavinį pagrindiniai klausimai yra: 1) ar lokalų centrą sudarančios viešosios erdvès lengvai pasiekiamos iš bet kurios vietos mieste ir lokalų centrą supančių gyvenamuju kvartalų; 2) koks urbanistinei kompozicijai didelę reikšmę turinčių užstatymo struktūros elementų vaidmuo, atsižvelgiant i jų ryši su kompozicinėmis ašimis ir mazgais.

Iš pirmajame tyrimų etape ịvardytų Vilniaus miesto lokalių centrų Šeškinès, Fabijoniškių ir Pašilaičių gyvenamụjų rajonų centrai buvo atrinkti išsamiam tyrimui. Remtasi šiais kriterijais: 1) nagrinejjamas lokalus centras yra gyvenamojo rajono aktyvios veiklos židinys, t. y. nuo žmonių judejjimo priklausančių prekybos, viešojo maitinimo ir kitas kasdienes paslaugas teikiančių imonių sankaupa; 2) gyvenamaji rajoną su pagrindiniu miesto centru jungia viso miesto mastu tiesiausios ir ilgiausios gatvių atkarpos (užmiesčio kelių tęsiniai); 3) apylygis gyventojų skaičius (tankis) gyvenamajame rajone ${ }^{41}$; 4) gyvenamojo rajono lokalaus centro urbanistinès plètros koncepcija yra neparengta (arba

\footnotetext{
${ }^{41}$ Nors gyventojų skaičius mieste nuolat kinta, šiame moksliniame darbe remiamasi prielaida, kad industrinès statybos laikotarpiu suformuotuose Šeškinès, Fabijoniškių ir Pašilaičių rajonuose gyventojų skaičius (tankis) yra apylygis.
} 
parengta, tačiau neigyvendinta ${ }^{42}$. Šiuos kriterijus atitiko vidurinejje dalyje, abipus Ukmergès gatvès, sovietiniais metais suplanuoti centrai, kuriems, atkūrus Lietuvos nepriklausomybę, didelès įtakos turejo savaiminio formavimosi procesas, kai lokalių centrų plètra iš esmès nebuvo reguliuojama. Kitas svarbus veiksnys yra autoriaus sukaupta asmeninè patirtis bei galimybès stebèti Šeškinès, Fabijoniškių ir Pašilaičių gyvenamujų rajonų viešosiose erdvėse vykstančius žmonių judejjimo, naujų funkcijų atsiradimo ir kitus socialinius bei ekonominius procesus.

Nagrinejjami industrinès statybos laikotarpiu suformuoti Vilniaus lokalūs centrai, jų vieta mieste, užstatymo struktūros, gatvių ir pésčiųjų takų tinklo formavimo sprendimai paremti to meto reikalavimus tenkinančiais planavimo principais. Vieni iš svarbiausių veiksnių, ị kuriuos buvo atsižvelgiama parenkant vietą gyvenamojo rajono centrui, buvo jo pasiekiamumas pėsčiomis (vadinamoji traukos zona) ir gyventojų skaičius (tankis). Komercinių pastatų išdèstymą, pagrindinių ịejimų vietas ir ryši su gatvès erdve paprastai nulemdavo meniniai sprendimai. Kita problema yra susijusi su urbanistinès erdvès konfigūracija bei nagrinejjamų centrų plano neužbaigtumu ir (arba) neefektyvumu. Dèl nustatyto reikalavimo, kad kasdienès paslaugos būtų pasiekiamos pésčiomis, to meto sprendimai priklausė nuo pasiekiamumo spindulio ${ }^{43}$, tačiau pralaidumo (gatvių tinklo „susisiekiamumo“) ir lokalių centrų bei jų urbanistinio konteksto jungiamumo klausimams nebuvo skiriama pakankamai dèmesio.

Dauguma nagrinèjamų lokalių centrų plano trūkumų buvo užprogramuoti rajonų koncepcinèse schemose, kuriose buvo numatyti nuo gatvès atitraukti stambūs gyvenamieji pastatai bei atskirai stovintys prekybos ir paslaugu pastatai arba kompleksai. Galima ịvardyti šias dvi svarbiausias problemas nagrinejjamoje miesto dalyje: 1) susipynusių viešujų ir privačiu (pusiau privačių) erdvių struktūra, lemianti per didelị viešųjų erdvių tinklo elementų pralaidumą (,susisiekiamumą"); 2) gatvès erdvès, ribojamos neefektyviai naudojamų žaliujų plotų, antžeminių automobilių stovejimo aikštelių ir indiferentiškų aklinų fasadų, išsidriekimas. Pirma problema gali būti atskleidžiama nagrinèjant pavyzdžius, kai tas pats urbanistinès erdvès elementas gali būti vadinamas ir privačia, ir viešaja erdve. Antra problema paprastai nagrinejjama vertinant funkcijų išsidestymą ir numatant galimybes pertvarkyti užstatymo struktūrą, t. y. perplanuoti

42 Šeškinès lokalaus centro urbanistinès plètros koncepcija yra ịgyvendinta iš dalies, fragmentiškai: atnaujinti esami ir pastatyti nauji biurų ir prekybos kompleksai. Fabijoniškių ir Pašilaičių lokalių centrų urbanistinès plètros koncepcijos nebuvo rengiamos. Fabijoniškèse rekonstruota keletas esamų ir pastatyta naujų komercinès paskirties pastatų. Pašilaičių lokalaus centro urbanistinis kompleksas iš esmès nepasikeitęs nuo jo pastatymo.

${ }^{43}$ Sovietiniais metais, matuojant pasiekiamumą, spindulys paprastai buvo brèžiamas vadinamuoju ,as the crow flies“ būdu, neatsižvelgiant ị viešujų erdvių tinklo ypatumus. 
esamus pastatus ir įtraukti naujus elementus. Kai kurių planavimo sprendimų, pavyzdžiui, lokalių centrų formavimo atskiriant pessčiuju ir automobilių srautus, bei dèl miesto plano neužbaigtumo ir (arba) neefektyvumo kylančių prieštaringumų ryši yra tikslinga atskleisti nustatant viešujų erdvių pasiekiamumo vertes, padedančias išryškinti funkcinę struktūrą, ir įvertinant erdvę formuojančių pastatų vaidmenį.

Nagrinejjamų lokalių centrų ribos nèra tiksliai apibrèžiamos. Tyrimų objektas yra tie viešujų erdvių tinklo struktūros elementai, kurie tarpusavyje susieti saitais ir kuriuose yra traukos objektai. Siekiant preliminariai nustatyti lokalių centrų ribas, svarbu ivvertinti juos sudarančių kvartalų išsidėstymo, atsižvelgiant $i$ jų dydị, ir lokalių centrų pasiekiamumo pėsčiomis ypatumus (2.5 ir 2.6 pav.). Pirmojoje schemoje naudojant raudonos bei mèlynos spalvų skalę vaizduojamas Šeškinès, Fabijoniškių ir Pašilaičių gatvių ir kitų viešujų erdvių ribojamų kvartalų masyvas išsiskiria netolygia sąskaida. Tai iš dalies atitinka bendrą principą, kad lokalų centrą sudaro mažesni kvartalai, lokalaus centro pakraščio ir esantys už centro ribu - didesni. Antrojoje schemoje vaizduojamas sovietiniais metais suplanuotų aktyvios veiklos židinių artimumas gretimuose kvartaluose gyvenantiems žmonèms, atsižvelgiant ị gatvių ir kitų viešujų erdvių ypatumus.

Funkcinių ašių - urbanistinèje erdvejje besidriekiančių žmonių judejjimo kelių (maršrutų) dalių - planas sudarytas iš linijinių elementų (gatvès atkarpų tarp sankryžų). Nagrinèjant lokalių centrų esamą būklę, funkcinių ašių sankirtose žymimi funkciniai mazgai ir apibūdinami jų ypatumai. Remiantis nustatytais funkcinès struktūros ypatumais, funkciniai mazgai skirstomi i tris kategorijas. Pirmos, aukščiausios, kategorijos funkciniai mazgai yra tokie, kuriuose susikertančioms funkcinèms ašims yra priskirtos dviejų ir daugiau pagrindinių iejjimų i skirtingus traukos objektus vietos, antros kategorijos - bent vieno pagrindinio iejjimo ị traukos objektą (pavienę prekybos ar paslaugu įmonę) vieta. Visi likę funkciniai mazgai yra trečios kategorijos. Funkcinių mazgų skirstymas i tris kategorijas remiantis pagrindinių iejjimu i traukos objektus skaičiumi yra pagrịstas lokalių centru augimo dèl vadinamojo didinamojo (multiplikatoriaus) efekto (multiplier effect), kuris parodo naujų traukos objektų atsiradimo ir žmonių srautų padidèjimo tarpusavio priklausomybę, galimybèmis. Aktyvios veiklos telkiniai turi daugiausia galimybiu plètotis, tačiau pavienès prekybos ar paslaugu įmonés, esant tam tikroms aplinkybėms, taip pat gali pritraukti naujų įmonių. 


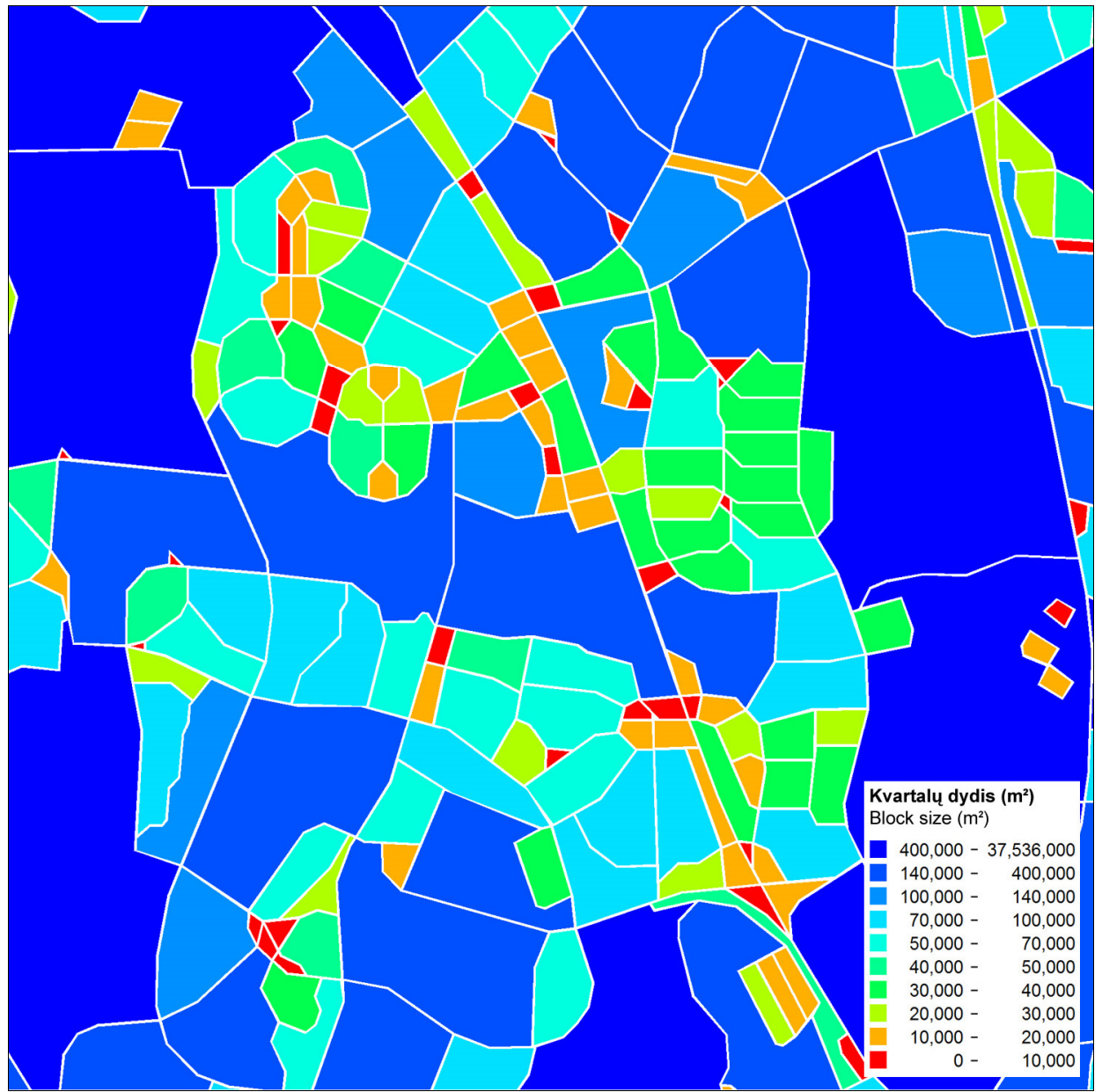

2.5 pav. Šeškinès, Fabijoniškių ir Pašilaičių gyvenamujų rajonų kvartalų išsidèstymo, atsižvelgiant i jų dydi, schema

Fig. 2.5. The arrangement and size of blocks of the residential districts of Šeškinè, Fabijoniškès and Pašilaičiai 


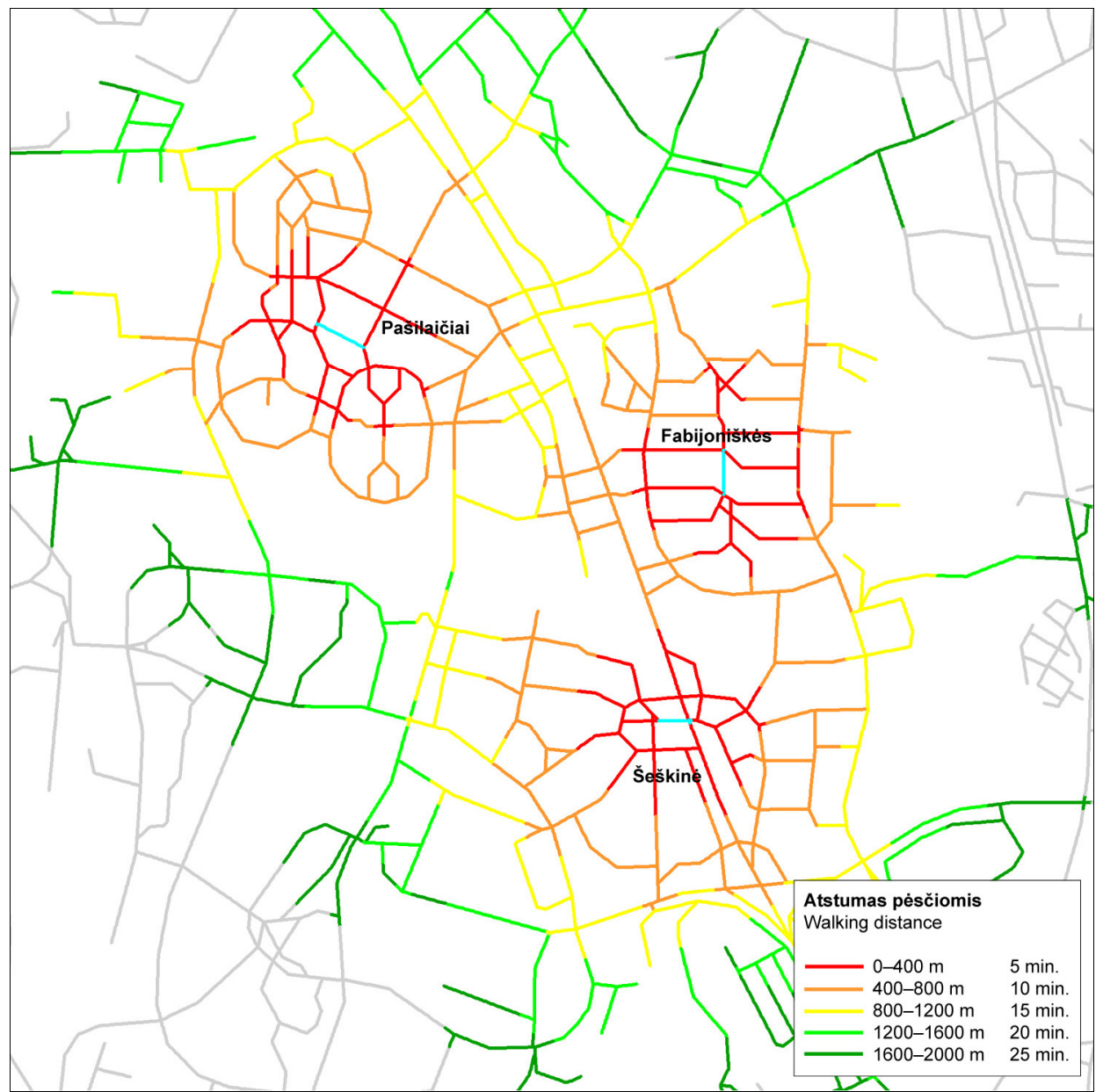

2.6 pav. Šeškinès, Fabijoniškių ir Pašilaičių lokalių centrų pasiekiamumo pėsčiomis schema

Fig. 2.6. Walking distances to the local centres of Šeškinè, Fabijoniškès and Pašilaičiai

Kuriant miesto kompozicinès struktūros modelị, urbanistinès erdvės konfigūracija ir meninis sprendimas atskleidžiami per kompozicinių ašių ir mazgų tinklą. İvertinamos viešųjų erdvių pobūdị atspindinčios urbanistinès kompozicijos savybės ir trumpai aprašomos nagrinèjamus lokalius centrus kertančių maršrutų skiriamosios ypatybės. Miesto vizualinis suvokimas (visual perception) yra vienas iš svarbiausių urbanistinio planavimo ir projektavimo aspektų, sprendžiant miesto, jo dalies ar kvartalų grupès urbanistinès struktūros formavimo klausimus. Tiriant urbanistinès erdvės kompozicijos ypatumus yra taikomi įvai- 
rūs miesto vaizdo stebejjimo metodai ir naudojamos šiuolaikiškos matavimo ir vaizdo fiksavimo priemonès (fotografavimas, filmavimas, eskizavimas, schemų ir grafikų braižymas, topografinis matavimas, kartografavimas ir kt.): nustatomas vizualiai atskirų urbanistinès erdvès dalių dydis, pločio ir gylio santykis, vertinami pastatų fasadai, tvoros ir kiti erdvę formuojantys elementai bei pažymimos pagrindinių iejjimų i pastatus vietos. Planuojant tyrimą kai kuriuos urbanistinès erdvès kompozicijos ypatumus galima preliminariai įvertinti naudojantis panoraminių gatvių nuotraukų, gautų fiksuojant vaizdus ant automobilio tvirtinama specialia kamera, peržiūros internete paslauga ${ }^{44}$. Iš visų i̇vardytų metodų šiame moksliniame darbe pasirinkti ir vykdant natūrinius tyrimus taikyti gatvių ir kitų nagrinejjamų lokalių centrų viešųų erdvių fotografavimo, pastatų fasadų, tvorų ir kitu erdvę formuojančių elementų vertinimo bei pagrindinių iejjimų i pastatus vietų žymèjimo plane metodai.

\subsubsection{Funkcinès struktūros tyrimas}

Sovietiniais metais Vilniaus šiaurès vakarų dalyje igyvendinti miesto plètros planai ir suformuoti nauji gyvenamieji rajonai. Naujujų miestų dalių teritorijos buvo užstatomos remiantis modernistinio (laisvojo) planavimo principais miesto visumos skaidymu i dalis, zonas ir rajonus, kuriems stengtasi paskirti pavienes funkcijas: gyvenamają, darbo (gamybos) ir poilsio (rekreacijos). Atskirtu funkcijų ir aktyvios veiklos židinių trūkumo gyvenamuosiuose rajonuose pasekmé yra didelis kasdienių kelionių poreikis ir lengvojo automobilio naudojimas susisiekimui.

Funkcinès struktūros tyrimo uždavinys - įvertinti sovietinių metų statybos Šeškinès, Fabijoniškių ir Pašilaičių gyvenamųjų rajonų lokalių centrų viešųjų erdviu tinklo struktūros formavimo trūkumus ir plètojimo galimybes. Naudojamas Vilniaus miesto viešujų erdvių pasiekiamumo modelis. Taikant space syntax metodiką nustatomos viešujų erdvių pasiekiamumo $800 \mathrm{~m}, 2000 \mathrm{~m}$ ir neapibrěžtu spinduliu, vadinamuoju radius $n$, kur $\mathrm{n}$ - begalybè, vertès (pasirinkimo arba matematinio pereinamumo). Modelis pateikiamas grafiškai, naudojant raudonos bei mėlynos spalvų skalę. Tiriant funkcinę struktūrą nustatomas žmoniu judèjimo ir vizualinis potencialas nagrinejjamose gatvių atkarpose (2.1 lentelè).

\footnotetext{
${ }^{44}$ Google Street View [žiūrèta 201206 07]. Prieiga per internetą: http://google.lt/ streetview. Disertacijos rengimo laikotarpiu nesinaudota „Google Street View“ paslauga, kadangi Lietuvos miestų panoraminès gatvių nuotraukos nebuvo prieinamos internete. 2013 m. sausio 31 d. Lietuvoje pradejo veikti „Google Street View“ paslauga.
} 
2.1 lentelè. Funkcinès struktūros tyrimo modelis

Table 2.1. Model for the analysis of functional structure

\begin{tabular}{|c|c|c|}
\hline $\begin{array}{l}\text { Modelio } \\
\text { elementai }\end{array}$ & $\begin{array}{l}\text { Modelio elementu } \\
\text { vaizdavimas plane }\end{array}$ & Modelio elementų apibūdinimas \\
\hline Funkcinės ašys & Linijos, linijiniai elementai & $\begin{array}{l}\text { Netrukdomo judejjimo ašys, } \\
\text { urbanistineje erdvejje besidriekiančios } \\
\text { žmonių judejimo kelių (maršrutų) dalys }\end{array}$ \\
\hline Funkciniai mazgai & Linijų sankirtos & $\begin{array}{l}\text { Gatvių sankirtos ar susiliejimo vieta } \\
\text { urbanistinejje erdvèje }\end{array}$ \\
\hline Traukos objektai & $\begin{array}{l}\text { Išryškinti pastatų kontūrai ir jų } \\
\text { užimamas plotas }\end{array}$ & $\begin{array}{l}\text { Pastatai, kuriuose įsikūrusios } \\
\text { kasdienius gyventoju poreikius tenki- } \\
\text { nančios prekybos ir paslaugų įmonės }\end{array}$ \\
\hline $\begin{array}{l}\text { Pagrindinių } \\
\text { jèjimų vietos }\end{array}$ & $\begin{array}{l}\text { Taškai, pažymėti ant pastatų } \\
\text { kontūrų ir priskirti artimiausiai } \\
\text { funkcinei ašiai }\end{array}$ & $\begin{array}{l}\text { Pagrindiniai iejjimai ị komercinius, } \\
\text { administracinius, gyvenamuosius ir } \\
\text { kitus pastatus, turinčius nevienodą įtaką } \\
\text { žmonių srautams }\end{array}$ \\
\hline $\begin{array}{l}\text { Vizualiai atskiros } \\
\text { urbanistinès } \\
\text { erdvės dalys } \\
\text { (convex spaces) }\end{array}$ & $\begin{array}{l}\text { Išryškinti atskirų erdvių } \\
\text { kontūrai ir jų užimamas plotas }\end{array}$ & $\begin{array}{l}\text { Viešosios erdvès, tiesiogiai ir vientisai } \\
\text { suvokiamos (t. y. vienu žvilgsniu } \\
\text { aprejpiamos), lengvai suprantamos } \\
\text { vietos urbanistineje erdveje }\end{array}$ \\
\hline
\end{tabular}

Siekiant nustatyti nagrinejamo lokalaus centro pastatų funkcijas (land uses) vykdomas natūrinis tyrimas, t. y. duomenys apie pastatus renkami lankantis tiriamojoje miesto dalyje, arba naudojamasi jau sukurtomis geografinių informacinių sistemų (GIS) duomenų bazèmis (Krupickaitè, Beconytė 2011).

Pagal svarbą ir vaidmenį, užtikrinant lokalių centrų gyvybingumą ir galimybes plètotis, pastatų funkcijos yra skirstomos i tris kategorijas (2.2 lentelè). Vertinant dominančių itaką miesto struktūrai yra atsižvelgiama i šių pastatų, pastatų kompleksų ar statinių paskirti (funkcijas), iš kurių svarbiausios pirmos kategorijos - yra reprezentacinès (viso miesto mastu svarbios administracinès, religinès bei kitos valstybinès ir visuomeninès funkcijos) ir tokios, kurioms apibūdinti vartojamas aktyvios veiklos terminas (prekybos, viešojo maitinimo, paslaugų ir kitų traukos objektų funkcijos). Antros kategorijos funkcijos yra administraciné (pavyzdžiui, biurai, savivaldybės ịstaigos, teismai), švietimo ir mokslo (pavyzdžiui, mokyklos ir vaikų darželiai). Trečios kategorijos funkcijos yra gyvenamoji ir kitos funkcijos, kurios nèra priskiriamos pirmai ir antrai kategorijai. 
2.2 lentelè. Pastatų funkcijų skirstymas ị kategorijas pagal jų svarbą ir vaidmenị, užtikrinant lokalių centrų gyvybingumą ir galimybes plètotis

Table 2.2. Defined categories of building functions considering their importance and role in ensuring the vitality and viability of local centres

\begin{tabular}{|c|c|}
\hline Kategorija & Pastatų funkcijos ir kriterijai joms apibūdinti \\
\hline 1 kategorija & $\begin{array}{l}\text { Reprezentacinès (viso miesto mastu svarbios administracinès, religinès } \\
\text { bei kitos valstybinès ir visuomeninés funkcijos). } \\
\text { Aktyvios veiklos (prekybos, viešojo maitinimo, paslaugų ir kitų } \\
\text { traukos objektų) }\end{array}$ \\
\hline 2 kategorija & $\begin{array}{l}\text { Administracinė (pvz., biurai, savivaldybės įstaigos, teismai). } \\
\text { Švietimo ir mokslo (pvz., mokyklos ir vaikų darželiai) }\end{array}$ \\
\hline 3 kategorija & $\begin{array}{l}\text { Gyvenamoji } \\
\text { Kitos funkcijos, kurios nėra priskiriamos pirmai ir antrai kategorijai }\end{array}$ \\
\hline
\end{tabular}

Lokalūs centrai išsiskiria iš kitų miesto dalių tuo, kad pirmos kategorijos funkcijos vyrauja urbanistinę erdvę ribojančiuose pastatuose. Nuo žmonių judejjimo priklausančios prekybos, viešojo maitinimo ir kitos kasdienes paslaugas teikiančios įmonès siekia įsikurti strategiškai svarbiose vietose, kad pagrindiniai ịjimai ir vitrinos būtų gerai matomos iš bet kurio gatvès erdvès taško. Gyvenamoji funkcija, daranti ịtaką lokaliu centrų gyvybingumui skirtingu paros metu, paprastai sudaro mažą procentinę dalį nuo visų pastatų pirmuosiuose aukštuose esančių patalpų. Antros kategorijos funkcijos turi mažesnę ịtaką, nes viešosios erdvès greta mokyklų, vaikų darželių ir biurų pastatų yra gyvybingos tik tam tikru paros metu.

Visuose trijuose nagrinejamuose lokaliuose centruose neintegruota gyvenamoji funkcija. Nors didžioji dalis prekybos ir paslaugų įmonių įsikūrusios atskirai stovinčiuose pastatuose, per paskutinius du dešimtmečius, trūkstant tinkamų patalpų, mažoms įmonèms atsirado poreikis įsikurti daugiabučiuose namuose. Lokalius centrus supančiu gyvenamosios paskirties pastatų pirmuosiuose aukštuose esantys butai buvo pritaikyti smulkiajam verslui (ịsikūré kirpyklos, grožio salonai, odontologų kabinetai ir kitos paslaugas teikiančios imonès). Kai kurių pirmos kategorijos funkcijų atsiradimui gyvenamuosiuose pastatuose įtakos turejo pastatų vieta nagrinejjamame gatvių tinkle ir jų atstumas nuo gatvés, taip pat nereiketuc atmesti ir palyginti nesudètingo patalpu pritaikymo, ypač paslaugas teikiančiu įmoniu veiklai vykdyti, nekeičiant esamo plano bei įrengiant atskirą iejjimą iš gatvès. Tokių objektų daugiausia Šeškinès gatvejje, mažiau - Fabijoniškių ir Pašilaičių lokalius centrus supančiuose kvartaluose. Šeškinès lokaliame centre laisvuose sklypuose įterpti nauji biurų pastatai, taip pat pertvarkyti ir išplèsti esami prekybos paskirties pastatai. Fabijoniškèse, S. Stanevičiaus gatvèje, pastatyta nauja parduotuvè. Pašilaičių 
lokaliame centre, neatsižvelgiant ị keletą naujai įsikūrusių smulkių prekybos ir paslaugų įmonių, didesnių pokyčių neužfiksuota.

Šeškinès, Fabijoniškių ir Pašilaičių lokalių centrų viešujų erdvių pasiekiamumo aukščiausios ir vidutinès vertès pateikiamos 2.3 lentelèje ir 2.7 paveiksle.

2.3 lentelè. Šeškinès, Fabijoniškių ir Pašilaičių lokalių centrų viešujų erdvių (linijinių elementu) pasiekiamumo vertès

Table 2.3. Spatial accessibility values assigned to linear elements in the local centres of Šeškinè, Fabijoniškès and Pašilaičiai

\begin{tabular}{|c|c|c|c|c|c|c|c|}
\hline \multirow{3}{*}{$\begin{array}{l}\text { Rajonas } \\
\text { (skliaustuose } \\
\text { linijụ } \\
\text { skaičius) }\end{array}$} & \multirow{3}{*}{$\begin{array}{l}\text { Vidutinis } \\
\text { linijos } \\
\text { ilgis, } m\end{array}$} & \multicolumn{6}{|c|}{ Viešųų erdvių pasiekiamumas } \\
\hline & & \multicolumn{2}{|c|}{ log_CH_R800_m } & \multicolumn{2}{|c|}{ log_CH_R2000_m } & \multicolumn{2}{|l|}{$\log _{-} \mathrm{CH}$} \\
\hline & & $\begin{array}{l}\text { Aukšč. } \\
\text { vertè }\end{array}$ & $\begin{array}{l}\text { Vidutinè } \\
\text { verte }\end{array}$ & $\begin{array}{l}\text { Aukšč. } \\
\text { verté }\end{array}$ & $\begin{array}{l}\text { Vidutinè } \\
\text { verté }\end{array}$ & $\begin{array}{l}\text { Aukšč. } \\
\text { verte }\end{array}$ & $\begin{array}{l}\text { Vidutinè } \\
\text { verté }\end{array}$ \\
\hline $\begin{array}{l}\text { Šeškinè } \\
\text { (52) }\end{array}$ & 111,3025 & 3,23477 & 2,80286 & 4,39405 & 3,68558 & 7,49197 & 5,16194 \\
\hline $\begin{array}{l}\text { Fabijoniškès } \\
\text { (41) }\end{array}$ & 120,1902 & 3,15564 & 2,59841 & 4,15531 & 3,46332 & 5,93877 & 4,8683 \\
\hline $\begin{array}{l}\text { Pašilaičiai } \\
\text { (29) }\end{array}$ & 104,6188 & 3,26647 & 2,99432 & 4,20855 & 3,75388 & 6,30409 & 5,28691 \\
\hline
\end{tabular}

Nagrinejjant apskaičiuotas lokalius centrus sudarančių viešųjų erdvių pasiekiamumo vidutines vertes, galima pastebèti, kad Šeškinès ir Pašilaičių lokalių centrų rodikliai yra aukštesni nei Fabijoniškių. Nors Pašilaičių lokalus centras, remiantis gautomis vidutinèmis vertemis, gali būti ịvardytas kaip geriausiai pasiekiamas $800 \mathrm{~m}, 2000 \mathrm{~m}$ spinduliu ir viso miesto mastu, tačiau Šeškinès lokalus centras išsiskiria aukščiausiomis vertemis, ypač vertinant Ukmergès gatvès pasiekiamumą $2000 \mathrm{~m}$ ir neapibrèžtu spinduliu.

Šeškinès, Fabijoniškių ir Pašilaičių pavyzdžiai rodo, remiantis tik viešųų erdvių pasiekiamumo vidutinèmis vertemis yra sunku nustatyti nuo viešųju erdvių konfigūracijos pokyčių priklausančias lokalių centrų galimybes (potencialą). Todèl, lankantis nagrinejamuose lokaliuose centruose, svarbu papildomai ịvertinti viešujų erdvių tinklo struktūros formavimo bei pėstiesiems, dviratininkams ir automobiliais atvykstantiems lankytojams pritaikytos infrastruktūros trūkumus ir plètojimo galimybes, atsižvelgiant ị esamus apribojimus. Tai gali padèti išsiaiškinti, kuriems viešujų erdvių gyvybingumui įtakos turintiems funkciniams aspektams turi būti skiriama daugiausia dèmesio, sprendžiant praktinius veiksmingos, efektyvios urbanistinès struktūros formavimo klausimus. 

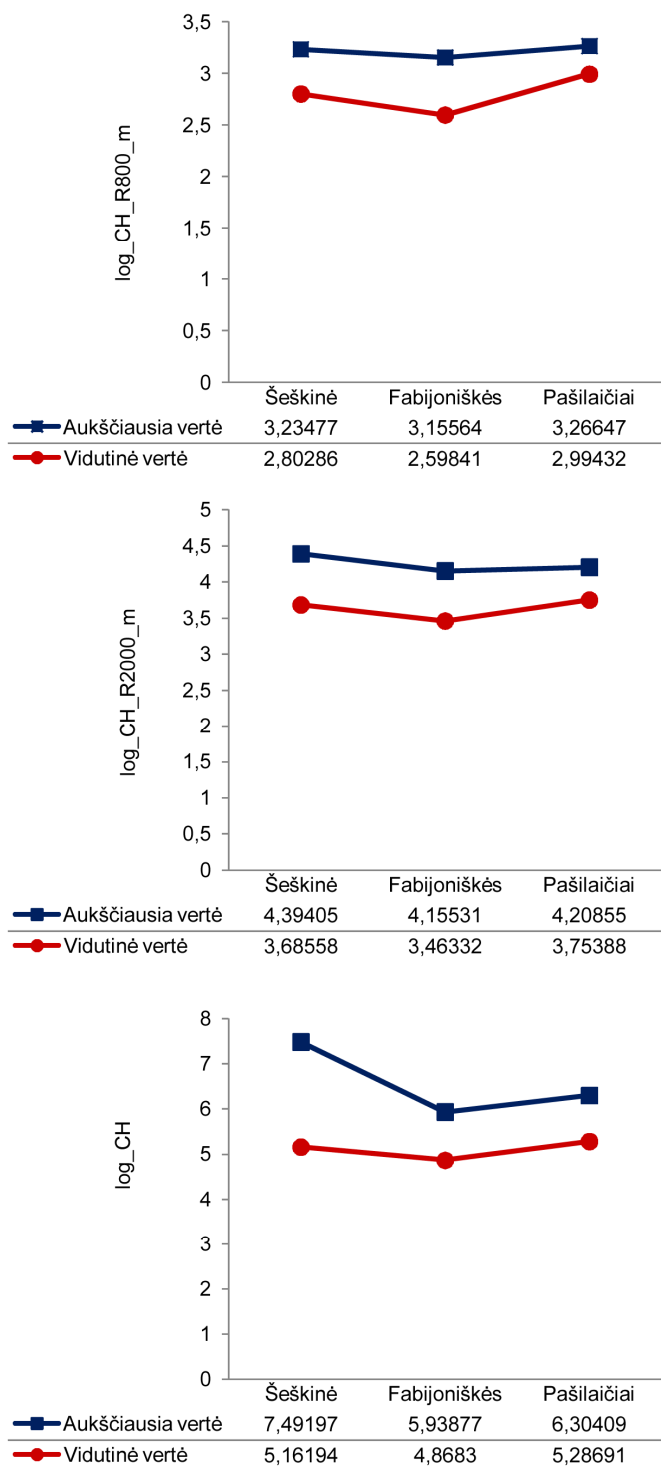

2.7 pav. Šeškinès, Fabijoniškių ir Pašilaičių lokalių centrų viešujų erdvių (linijinių elementų) pasiekiamumo $800 \mathrm{~m}, 2000 \mathrm{~m}$ ir neapibrèžtu spinduliu verčių diagramos Fig. 2.7. Diagrams showing spatial accessibility values ( $800 \mathrm{~m}$ radius, $2000 \mathrm{~m}$ radius, radius n) assigned to linear elements in the local centres of Šeškinè, Fabijoniškès and Pašilaičiai 
Šeškinès lokalaus centro viešuju erdvių tinklo struktūros formavimo bei pèstiesiems, dviratininkams ir automobiliais atvykstantiems lankytojams pritaikytos infrastruktūros trūkumai ir plètojimo galimybès, atsižvelgiant ị esamus apribojimus, pateikiamos 2.4-2.6 lentelèse.

2.4 lentelè. Šeškinès lokalaus centro viešujų erdvių tinklo struktūros formavimo trūkumai ir plètojimo galimybès

Table 2.4. Weaknesses and opportunities of the formation of street network in the local centre of Šeškinè

\begin{tabular}{|c|c|}
\hline Trūkumai & Galimybės \\
\hline $\begin{array}{l}\text { Ukmergès gatvė suprojektuota tik } \\
\text { automobilių eismui, neužtikrinant lokalų } \\
\text { centrą sudarančių viešujų erdvių jungiamumo. } \\
\text { Pėstieji ir dviratininkai, noredami pasiekti } \\
\text { abiejose gatvės pusėse esančius objektus, turi } \\
\text { pasirinkti vieną iš dvieju galimybių: naudotis } \\
\text { požemine perèja arba Šeškinės ir Ukmergės } \\
\text { gatvių dviejų lygių sankryža, kuria taip pat } \\
\text { intensyviai naudojasi automobiliais } \\
\text { atvykstantys lankytojai }\end{array}$ & $\begin{array}{l}\text { Ukmergės gatvės pertvarkymas iš greito } \\
\text { eismo gatvės į skirtingiems susisiekimo } \\
\text { būdams pritaikytą prekybinę gatvę, tiesiant } \\
\text { naujas jungtis ir įrengiant šviesoforais } \\
\text { reguliuojamas arba sulètinto eismo sankryžas, } \\
\text { leistu pagerinti sąlygas pėstiesiems, } \\
\text { dviratininkams ir automobiliais } \\
\text { atvykstantiems lankytojams, kirsti lokalų } \\
\text { centrą pasirenkant įvairius maršrutus ir } \\
\text { pasiekti skirtingose gatvės pusėse esančius } \\
\text { objektus }\end{array}$ \\
\hline
\end{tabular}

2.5 lentelè. Šeškinès lokalaus centro lankytojams - pèstiesiems ir dviratininkams pritaikytos infrastruktūros trūkumai ir plètojimo galimybès

Table 2.5. Weaknesses and opportunities of the provision of infrastructure for pedestrians and cyclists in the local centre of Šeškinè

\begin{tabular}{|c|c|}
\hline Trūkumai & Galimybès \\
\hline $\begin{array}{l}\text { Vienas iš akivaizdžių Šeškinès lokalaus } \\
\text { centro viešosios erdvès trūkumų yra žema } \\
\text { urbanistinės aplinkos kokybè, pessčiujų ir } \\
\text { dviratininkų poreikių neatitinkantys } \\
\text { urbanistiniai sprendimai. Pavyzdžiui, virš } \\
\text { žemės pakelti pėsčiujų takai, koridorių } \\
\text { primenantis praèjimas ir požeminè perejja, } \\
\text { kurių žmonès vengia tamsiuoju paros metu, } \\
\text { yra nepatrauklūs ir nepatogūs naudoti }\end{array}$ & $\begin{array}{l}\text { Patogios jungtys su aplinkinių gatvių tinklu ir } \\
\text { aukštos kokybės infrastruktūra, tik } \\
\text { automobiliams skirtoje Ukmergès gatvèje } \\
\text { irengiant šaligatvius ir dviračių takus bei } \\
\text { teikiant pirmenybę antžeminėms pèsčiujjų } \\
\text { perėjoms, padètų sukurti palankią žmogui } \\
\text { viešąąą erdvę ir užtikrinti lankytoju srautą. } \\
\text { Minèti sprendimai aktualūs ir viešuoju } \\
\text { transportu atvykstantiems lankytojams }\end{array}$ \\
\hline
\end{tabular}


2.6 lentelè. Automobiliais atvykstantiems Šeškinès lokalaus centro lankytojams pritaikytos infrastruktūros trūkumai ir plètojimo galimybès

Table 2.6. Weaknesses and opportunities of the provision of infrastructure for vehicles in the local centre of Šeškinè

\begin{tabular}{|c|c|}
\hline Trūkumai & Galimybès \\
\hline $\begin{array}{l}\text { Didesnių lokalaus centro pasiekiamumo } \\
\text { automobiliu trūkumų nenustatyta. Priešingai, } \\
\text { galimybė atvykti i lokalų centrą vedančiomis } \\
\text { Paberžès, Musninkų ir Dūkštų gatvėmis bei } \\
\text { sudarytos sąlygos statyti automobilius } \\
\text { Šeškinės gatvejje yra didelis privalumas. } \\
\text { Nenumatyta galimybe kirsti Ukmergès gatvę } \\
\text { pasirenkant ịvairius maršrutus iš dalies } \\
\text { apriboja pirmą kartą iš šiaurès ir pietų pusės } \\
\text { atvykstančių lankytojų patekimą ì lokalų } \\
\text { centra }\end{array}$ & 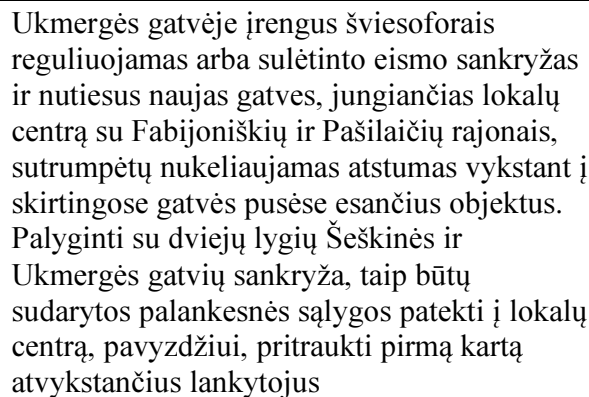 \\
\hline
\end{tabular}

Fabijoniškių lokalaus centro viešujų erdvių tinklo struktūros formavimo bei pèstiesiems, dviratininkams ir automobiliais atvykstantiems lankytojams pritaikytos infrastruktūros trūkumai ir plètojimo galimybès, atsižvelgiant ị esamus apribojimus, pateikiamos 2.7-2.9 lentelèse.

2.7 lentelè. Fabijoniškių lokalaus centro viešụų erdvių tinklo struktūros formavimo trūkumai ir plètojimo galimybès

Table 2.7. Weaknesses and opportunities of the formation of street network in the local centre of Fabijoniškès

\begin{tabular}{|c|c|}
\hline Trūkumai & Galimybès \\
\hline $\begin{array}{l}\text { Gyvenamojo rajono viduje esanti lokalaus } \\
\text { centro dalis yra per mažai integruota ị } \\
\text { pagrindinių gatvių tinklą. Nėra skersinių } \\
\text { gatvių, jungiančių Fabijoniškių ir } \\
\text { S. Stanevičiaus gatves; šiuo metu tokia } \\
\text { jungtis - pėstiesiems skirtas koridorių } \\
\text { primenantis praejjimas, o Fabijoniškių } \\
\text { seniūnijos pastatas yra kliūtis siekiant nutiesti } \\
\text { gatvę. Iš Ukmergès gatvės į lokalų centrą } \\
\text { patenkama (neskaitant pésčiujų praėjimo tarp } \\
\text { daugiaaukščių garažu) mažiausiai tris kartus } \\
\text { pakeitus judejimo krypti }\end{array}$ & $\begin{array}{l}\text { Lokalaus centro pasiekiamumas gali būti } \\
\text { pagerintas i̇rengus patogias Fabijoniškių ir } \\
\text { S. Stanevičiaus gatvių jungtis bei užtikrinus } \\
\text { galimybę iš Ukmergès gatvės tiesiogiai (t. y. } \\
\text { padarius vieną posūki) patekti ị lokalų centrą. } \\
\text { Kita svarbi Fabijoniškiu ir Š Šškinès lokalių } \\
\text { centru jungtis - per nebaigtą formuoti slènị } \\
\text { vedantis pésčiujų takas, galintis tapti nauja } \\
\text { plètros ašimi }\end{array}$ \\
\hline
\end{tabular}


2.8 lentelè. Fabijoniškių lokalaus centro lankytojams - pėstiesiems ir dviratininkams pritaikytos infrastruktūros trūkumai ir plètojimo galimybès

Table 2.8. Weaknesses and opportunities of the provision of infrastructure for pedestrians and cyclists in the local centre of Fabijoniškès

\begin{tabular}{|c|c|}
\hline Trūkumai & Galimybės \\
\hline $\begin{array}{l}\text { Gyvenamojo rajono pėsčiujjų takų tinklas yra } \\
\text { tankus ir atitinka pasirenkamas judejjimo } \\
\text { kryptis, tačiau žmonès pasirenka kirsti } \\
\text { S. Stanevičiaus gatvę neleistinose vietose. } \\
\text { Kitas trūkumas yra žema urbanistinės aplinkos } \\
\text { kokybe, ypač nebaigtoje formuoti vakarineje } \\
\text { lokalaus centro dalyje. Dviračių takai ịrengti } \\
\text { Fabijoniškių ir S. Stanevičiaus gatvėe, tačiau } \\
\text { nesuplanuoti gyvenamojo rajono viduje, } \\
\text { trūksta Fabijoniškių ir Ukmergès gatvių } \\
\text { jungčių }\end{array}$ & $\begin{array}{l}\text { Fabijoniškių ir S. Stanevičiaus gatves } \\
\text { sujungus skersinėmis gatvėmis, skirtomis } \\
\text { sulėtintam eismui (iki } 20 \mathrm{~km} / \mathrm{h} \text { ), jų } \\
\text { važiuojamaja dalimi galètų naudotis } \\
\text { dviratininkai, pėstiesiems būtų skirti esami } \\
\text { šaligatviai. Minėtų gatvių sankirtose su } \\
\text { S. Stanevičiaus gatve ịrengus šviesoforais } \\
\text { reguliuojamas arba sulètinto eismo sankryžas } \\
\text { pagerėtų sąlygos pėstiesiems ir } \\
\text { dviratininkams, norintiems pasiekti šią naujai } \\
\text { besiformuojančią lokalaus centro dalị }\end{array}$ \\
\hline
\end{tabular}

2.9 lentelè. Automobiliais atvykstantiems Fabijoniškių lokalaus centro lankytojams pritaikytos infrastruktūros trūkumai ir plètojimo galimybès

Table 2.9. Weaknesses and opportunities of the provision of infrastructure for vehicles in the local centre of Fabijoniškès

\begin{tabular}{|c|c|}
\hline Trūkumai & Galimybès \\
\hline 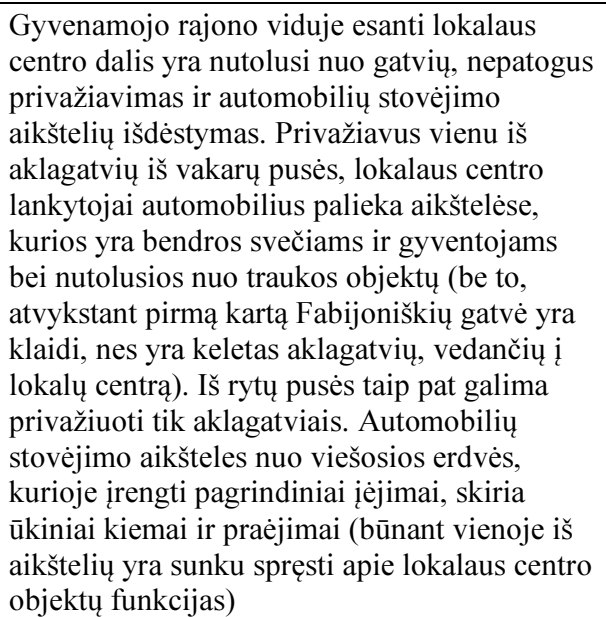 & 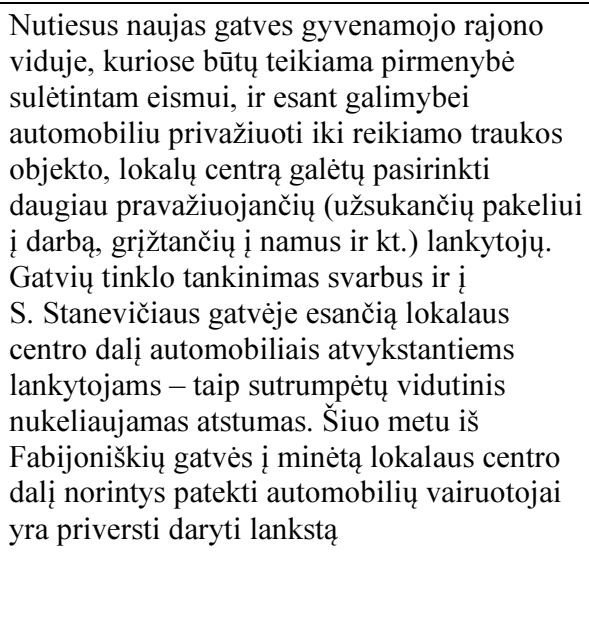 \\
\hline
\end{tabular}

Pašilaičių lokalaus centro viešujų erdvių tinklo struktūros formavimo bei péstiesiems, dviratininkams ir automobiliais atvykstantiems lankytojams pritaikytos infrastruktūros trūkumai ir plètojimo galimybès, atsižvelgiant ị esamus apribojimus, pateikiamos 2.10-2.12 lentelèse. 
2.10 lentelè. Pašilaičių lokalaus centro viešujų erdvių tinklo struktūros formavimo trūkumai ir plètojimo galimybès

Table 2.10. Weaknesses and opportunities of the formation of street network in the local centre of Pašilaičiai

\begin{tabular}{|c|c|}
\hline Trūkumai & Galimybès \\
\hline $\begin{array}{l}\text { Lokalų centrą su pagrindine gyvenamaji } \\
\text { rajoną kertančia gatve - Laisvès prospektu - } \\
\text { jungia pésčiujju takas. Automobiliais } \\
\text { atvykstantys lankytojai naudojasi painiomis } \\
\text { kreivaeigio judejjimo gatvių jungtimis. Nors } \\
\text { minėtose gatvèse irengta reikiama pesčiujų } \\
\text { ir dviračių takų infrastruktūra, esamos } \\
\text { jungtys neatitinka pasirenkamų kirsti lokalų } \\
\text { centrą maršrutu }\end{array}$ & 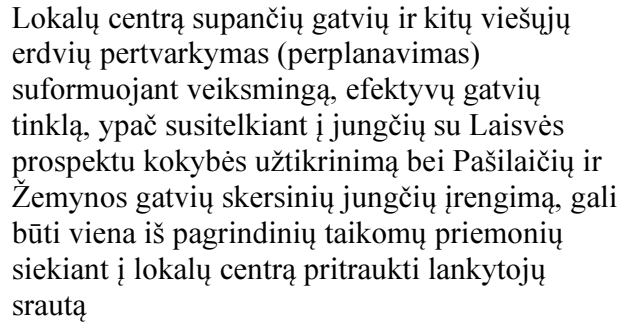 \\
\hline
\end{tabular}

2.11 lentelè. Pašilaičių lokalaus centro lankytojams - pėstiesiems ir dviratininkams pritaikytos infrastruktūros trūkumai ir plètojimo galimybès

Table 2.11. Weaknesses and opportunities of the provision of infrastructure for pedestrians and cyclists in the local centre of Pašilaičiai

\begin{tabular}{|c|c|}
\hline Trūkumai & Galimybès \\
\hline $\begin{array}{l}\text { Reikiama pėsčiujjų ir dviračių takų } \\
\text { infrastruktūra sukurta, bet netolygiai } \\
\text { išplètota ir suplanuoti takai ne visur atitinka } \\
\text { pasirenkamas judejjimo kryptis. Trūkumas } \\
\text { yra tas, kad dviračių takai nenumatyti šalia } \\
\text { pessčiujju tako, jungiančio lokalu centrą su } \\
\text { viešojo transporto mazgu. Dviračių takų } \\
\text { nėra ir susisiekimui su kitomis miesto } \\
\text { dalimis svarbiame Laisvès prospekte, } \\
\text { kertančiame kitus gyvenamuosius rajonus ir } \\
\text { jų lokalius centrus }\end{array}$ & $\begin{array}{l}\text { Nors lokalaus centro vieta ir nėra patogi } \\
\text { viešuoju transportu besinaudojantiems } \\
\text { gyventojams, plètojant pėsčiujų ir dviračių takų } \\
\text { tinklą, atitinkantị jų naudotojų pasirenkamus } \\
\text { kelius (maršrutus), ypač numačius galimybę } \\
\text { kirsti Laisvès prospektą, įrengiant pėstiesiems ir } \\
\text { dviratininkams pritaikytas šviesoforais } \\
\text { reguliuojamas arba sulètinto eismo sankryžas } \\
\text { bei viešojo transporto stoteles, būtų sudarytos } \\
\text { sąlygos geriau išnaudoti šių keliavimo būdų } \\
\text { privalumus }\end{array}$ \\
\hline
\end{tabular}

2.12 lentelè. Automobiliais atvykstantiems Pašilaičių lokalaus centro lankytojams pritaikytos infrastruktūros trūkumai ir plètojimo galimybès

Table 2.12. Weaknesses and opportunities of the provision of infrastructure for vehicles in the local centre of Pašilaičiai

\begin{tabular}{|c|c|}
\hline Trūkumai & Galimybès \\
\hline $\begin{array}{l}\text { Automobiliais pirmą kartą atvykstantiems } \\
\text { lokalaus centro lankytojams yra sunku } \\
\text { susiorientuoti gatvių tinkle ir privažiuoti iki } \\
\text { reikiamo traukos objekto. Be to, lokalu } \\
\text { centrą sudarantis pastatu kompleksas yra } \\
\text { nutolęs nuo gatviu. Atvykstant Pašilaičiu, } \\
\text { Gabijos ir Medeinos gatvemis ir norint } \\
\text { patekti i lokalaus centro automobiliu } \\
\text { stovèiimo aikštele, tenka darvti lanksta }\end{array}$ & $\begin{array}{l}\text { Pertvarkius kai kuriuos viešujų erdvių tinklo } \\
\text { elementus būtų paprasčiau pasiekti lokalu } \\
\text { centrą sudaranti pastatŭ kompleksa. Esant } \\
\text { galimybei iš Pašilaičiu gatvès tiesiogiai patekti i } \\
\text { lokalų centrą, lankytojai atvyktų trumpesniu } \\
\text { maršrutu ir darydami tik vieną posūki. Lokalų } \\
\text { centrą išplètus i Žemynos gatvès pusę ir } \\
\text { pakeitus gatvès konfigūraciją, būtų patogiau } \\
\text { privažiuoti iki reikiamo traukos objekto }\end{array}$ \\
\hline
\end{tabular}




\subsubsection{Funkcinès struktūros tyrimo išvados}

Šeškinès lokalaus centro gyvybingumą ir patrauklumą lankytojams galima būtų paaiškinti tuo, kad jo integracijos ir pasirinkimo - galimybès būti kelionès tikslu arba maršruto dalimi - rodikliai yra aukšti, t. y. jo vieta yra svarbi ir viso miesto mastu, ir aplink esančių viešujų erdvių kontekste. Tai turi didelès ịtakos pritraukiant ne tik lokalu centrą supančiose gatvèse gyvenančius žmones, bet ir pravažiuojančius (užsukančius pakeliui ị darbą, grįžtančius i namus ir kt.) lankytojus.

Fabijoniškių ir Pašilaičių lokalūs centrai yra „pasislępę“ gyvenamujų rajonų viduje ir gali būti įvardijami tik kaip kelionès tikslas, bet ne kaip kelionès iš tam tikros vietos i kitą pasirinktą vietą mieste dalis (t. y. lokalius centrus sudarančios viešosios erdvès nèra naudojamos pravažiuoti ar pereiti vykstant iš vienos vietos i kitą vietą mieste).

Šeškinès ir Pašilaičių lokalių centrų viešųjų erdvių pasiekiamumo vidutinès vertès yra aukštesnès nei Fabijoniškių. Nors Pašilaičių lokalus centras, remiantis gautomis vidutinèmis vertemis, gali būti ịvardytas kaip geriausiai pasiekiamas $800 \mathrm{~m}, 2000 \mathrm{~m}$ spinduliu ir viso miesto mastu, tačiau Šeškinès lokalus centras išsiskiria aukščiausiomis vertemis, ypač vertinant Ukmergès gatvès pasiekiamumą $2000 \mathrm{~m}$ ir neapibrèžtu spinduliu.

Papildomų veiksnių nagrinèjimas - viešųjų erdvių tinklo struktūros formavimo bei péstiesiems, dviratininkams ir automobiliais atvykstantiems lankytojams pritaikytos infrastruktūros trūkumų ir plètojimo galimybių ịvertinimas lankantis nagrinejjamuose lokaliuose centruose - išryškino neužtikrinto lokalius centrus sudarančių viešujų erdvių jungiamumo problemą ir leido nustatyti esamų viešujų erdvių kokybės gerinimo prioritetus.

Svarbiausi Šeškinès, Fabijoniškių ir Pašilaičių lokalių centrų viešujų erdvių tinklo struktūros formavimo trūkumai - esamos jungtys ne visada atitinka pasirenkamų kirsti lokalų centrą maršrutų ir dèl to kylantys sunkumai, norint susiorientuoti gatvių tinkle ir privažiuoti iki reikiamo traukos objekto. Esama galimybių pertvarkyti (perplanuoti) kai kuriuos nagrinètų lokalių centrų viešujų erdvių tinklo elementus, siekiant suformuoti veiksmingą, efektyvų gatvių tinklą. Taip būtų sudarytos sąlygos tiesiogiai patekti ị lokalų centrą ir sutrumpètų vidutinis nukeliaujamas atstumas. Siūlomos priemonès yra patogiu jungčių su aplinkinių gatvių tinklu ịrengimas, esamų sankryžų rekonstrukcija ir naujų gatvių, kuriose teikiama pirmenybè suletintam eismui, gyvenamujų rajonų viduje tiesimas. 


\subsubsection{Kompozicinès struktūros tyrimas}

Istorinèse (savaime susiformavusiose) miestų dalyse dominantès paprastai yra glaudžiai susijusios su miesto plano struktūra. Pavyzdžiui, galimybė gatvių sankryžoje matyti aukščiu arba tūriu išsiskiriantị pastatą (ypač jeigu tai reprezentacinès funkcijos objektas) dažnai lemdavo kelio - tolesnio kelionès maršruto atkarpos - pasirinkimą. Urbanistinei kompozicijai didelę reikšmę turinčios dominantès sovietiniais metais buvo išdèstomos remiantis meniniais principais, siekiant pagyvinti monotonišką gyvenamujjų rajonų vaizdą, tačiau parenkant jų vietas mažai dèmesio skirta urbanistinès erdvès konfigūracijos ir nuo žmonių judejjimo intensyvumo priklausančių užstatymo struktūros plètros galimybių ivertinimui.

Kompozicinès struktūros tyrimo uždavinys - ịvertinti sovietinių metų statybos Šeškinès, Fabijoniškių ir Pašilaičių gyvenamujų rajonų lokalių centrų užstatymo struktūros ir urbanistinès erdvės kompozicijos trūkumus ir plètojimo galimybes bei, atsižvelgiant $\mathfrak{i}$ esamus apribojimus, pasiūlyti jų pertvarkymo kryptis. Tyrimo metu, remiantis sudarytais modeliais, nagrinejjamas dominančių išsidèstymas ir ryšys su kompozicinèmis ašimis ir mazgais. Tiriant kompozicinę struktūrą nustatomas meninis ir vizualinis urbanistinès erdvès potencialas, priklausantis nuo atskirų erdvès dalių ir užstatymo struktūros elementų savybių (t. y. planuojant ši tyrimą siekta gauti tokius rezultatus, kurie leistų spręsti apie viešujų erdvių plètojimo galimybes) (2.13 lentelè).

2.13 lentelè. Kompozicinès struktūros tyrimo modelis

Table 2.13. Model for the analysis of compositional structure

\begin{tabular}{|c|c|c|}
\hline $\begin{array}{l}\text { Modelio } \\
\text { elementai }\end{array}$ & $\begin{array}{l}\text { Modelio elementų } \\
\text { vaizdavimas plane }\end{array}$ & Modelio elementų apibūdinimas \\
\hline Kompozicinės ašys & Linijos, ašinès linijos & $\begin{array}{l}\text { Vizualinès ašys, urbanistinėje erdvejje } \\
\text { besidriekiančių vizualinių ašių dalys }\end{array}$ \\
\hline $\begin{array}{l}\text { Kompoziciniai } \\
\text { mazgai }\end{array}$ & Linijų sankirtos & $\begin{array}{l}\text { Pagrindinès sankirtos (vartai ị miestą, } \\
\text { miesto dalị ar lokalų centrą) ir kitos } \\
\text { sankirtos }\end{array}$ \\
\hline Dominantès & $\begin{array}{l}\text { Sutartiniai žymenys (žr. } \\
\text { plano eksplikaciją) }\end{array}$ & $\begin{array}{l}\text { Vertikalios ir horizontalios dominantès - } \\
\text { pastatai ar statiniai, išsiskiriantys iš juos } \\
\text { supančių elementų aukščiu arba tūriu }\end{array}$ \\
\hline $\begin{array}{l}\text { Pagrindiniu įejjimų } \\
\text { vietos }\end{array}$ & $\begin{array}{l}\text { Taškai, pažymèti ant pastatų } \\
\text { kontūrų }\end{array}$ & $\begin{array}{l}\text { Pagrindiniai ịjjimai ị pastatus, } \\
\text { užtikrinantys pastatu vidaus erdvių ir } \\
\text { urbanistinės erdvės tarpusavio ryši }\end{array}$ \\
\hline $\begin{array}{l}\text { Vizualiai atskiros } \\
\text { urbanistinès erdvès } \\
\text { dalys (convex } \\
\text { spaces) }\end{array}$ & $\begin{array}{l}\text { Išryškinti atskirǔ erdvių } \\
\text { kontūrai ir jų užimamas } \\
\text { plotas }\end{array}$ & $\begin{array}{l}\text { Viešosios erdvès, tiesiogiai ir vientisai } \\
\text { suvokiamos (t. y. vienu žvilgsniu } \\
\text { aprèpiamos), lengvai suprantamos vietos } \\
\text { urbanistineje erdvèje }\end{array}$ \\
\hline
\end{tabular}




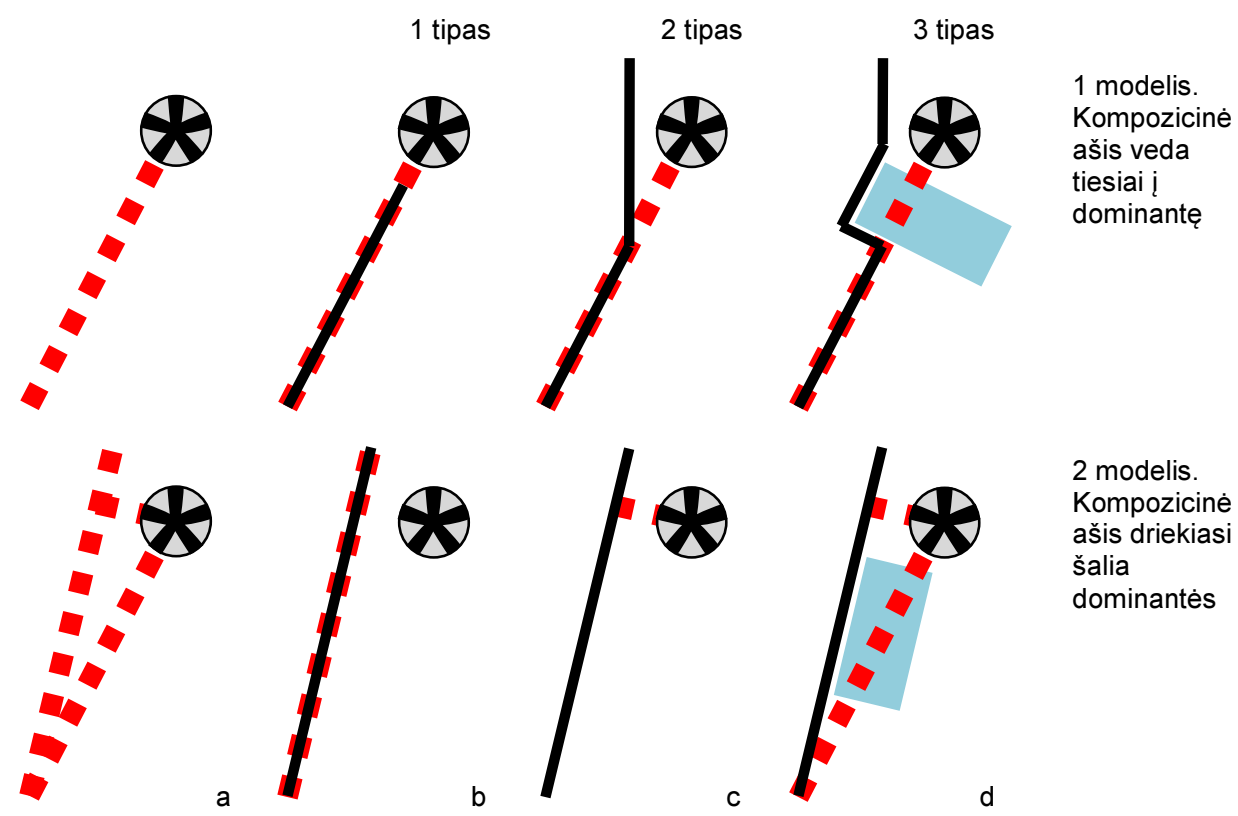

2.8 pav. Kompozicinių ašių ir dominančių tarpusavio ryšys: a - dominantė ir nagrinėjami vizualiniai ryšiai; $b$ - dominante ir vizualiniai ryšiai, sutampantys su kompozicinėmis ašimis; c - dominante ir vizualiniai ryšiai, iš dalies sutampantys su kompozicinėmis ašimis, kai matomumo neriboja vizualinès kliūtys; d - dominante ir vizualiniai ryšiai, iš dalies sutampantys su kompozicinėmis ašimis, kai matomumo neriboja natūralios kliūtys

Fig. 2.8. Interrelationship between compositional axes and dominant buildings: a dominant building and appropriate visual connections; $b$ - dominant building and visual connections, which overlap with compositional axis; $\mathrm{c}$ - dominant building and visual connections, which partially overlap with compositional axis, when visibility is not obstructed by visual barriers; $\mathrm{d}$ - dominant building and visual connections, which partially overlap with compositional axis, when visibility is not obstructed by natural barriers

2.8 paveiksle pavaizduoti du kompozicinių ašių ir dominančių tarpusavio ryšių modeliai. Dominantès (modelyje žymimos apskritimu) ir jos vizualinių ryšių (žymimų punktyrinėmis linijomis) pobūdi galima iliustruoti dviem pavyzdžiais (a). Kai kompozicinė ašis (juoda linija) veda tiesiai i dominantę, visada užtikrinamas vizualinis ryšys; jeigu kompozicinė ašis driekiasi šalia dominantès, vizualiniai ryšiai priklauso nuo urbanistinę erdvę ribojančių užstatymo struktūros elementų išsidèstymo: 
- vizualiniai ryšiai ir kompozicinès ašys sutampa (1 tipas);

1 modelyje dominante yra gerai matoma, vizualinis ryšys su tiesiai i dominantę vedančia kompozicine ašimi yra užtikrintas; 2 modelyje dominantè yra nematoma, vaizdą užstoja urbanistinę erdvę ribojantys užstatymo struktūros elementai, t. y. dominantè yra „pasislèpusi““ (b);

- vizualiniai ryšiai ir kompozicinès ašys iš dalies sutampa ir matomumo neriboja vizualinès kliūtys (2 tipas);

1 modelyje dominante yra gerai matoma, vizualinis ryšys su tiesiai i dominantę vedančia kompozicine ašimi yra užtikrintas, tačiau vizualinès kliūtys gali riboti matomumą iš kitų tarpusavyje susietų kompozicinių ašių; 2 modelyje dominante yra matoma tik iš vieno kompozicinès ašies taško, kituose taškuose vaizdą užstoja urbanistinę erdvę ribojantys užstatymo struktūros elementai (c);

- vizualiniai ryšiai ir kompozicinès ašys iš dalies sutampa ir matomumo neriboja natūralios kliūtys (3 tipas);

1 modelyje dominante yra gerai matoma, vizualinis ryšys su tiesiai i dominantę vedančia kompozicine ašimi yra užtikrintas, matomumas nėra ribojamas ir iš kitų tarpusavyje susietų kompozicinių ašių, pritaikytų prie natūralių kliūčių (pavyzdžiui, vandens telkinio kranto linijos); 2 modelyje dominante matoma iš keleto kompozicinès ašies taškų, matomumo neriboja natūralios kliūtys (pavyzdžiui, vandens telkinys) (d).

Siekiant įvertinti gatves, aikštes ir kitas viešąsias erdves, taikomi urbanistinès kompozicijos užbaigtumo (completeness), reikšmingumo (importance) ${ }^{45}$ ir būdingumo (distinctness of character) kriterijai (2.14 lentelè). Pagrindinis kriterijų ir jų tarpusavio derinimo šaltinis - V. Jurkšto sudaryta urbanistinès kompozicijos ir jos vizualinio suvokimo tyrimų metodika, apibūdinta 1.3.2 skyrelyje. Minèti kriterijai pasirinkti remiantis šiais principais, glaudžiai susijusiais su kelio (maršruto) pasirinkimo judant iš vienos miesto dalies ị kitą (taip pat ir susisiekimo būdo pasirinkimo) ir socialinès interakcijos viešosiose erdvèse galimybėmis: 1) užbaigtos kompozicijos viešosios erdvès yra savitos ir iš visų kitų viešujų erdvių tinklo elementų išsiskiriančios savo aiškiu suformavimu (pasižyminčios savo forma, aiškiai suformuotomis gatvès išklotinemis); 2) jų reikšmingumą lemia užstatymo struktūros elementų santykinè svarba: viešosios erdvès, kuriose yra dominantès, tampa unikaliomis, lengvai atpažistamomis ir suprantamomis vietomis (lankytis, susitikti, bendrauti); 3) urbanistinès kompozicijos būdingumas priklauso nuo užstatymo struktūros

${ }^{45}$ Reikšmingumas arba svarbumas (importance) neturètų būti painiojamas su prasmingumu (meaningfulness) - tam tikros prasmès turèjimu. 
2.14 lentelè. Urbanistinès kompozicijos ịvertinimo kriterijų apibūdinimas

Table 2.14. Description of evaluative criteria for urban composition

\begin{tabular}{|c|c|c|c|}
\hline \multirow{2}{*}{$\begin{array}{l}\text { Verte ir } \\
\text { vertinimo balai }\end{array}$} & \multicolumn{3}{|c|}{ Urbanistinės kompozicijos įvertinimo kriterijai ir jų apibūdinimas } \\
\hline & Užbaigtumas & Reikšmingumas & Būdingumas \\
\hline Aukšta & Užbaigta. & Reikšminga. & Turinti ryškių ypatybių \\
\hline 5 balai & $\begin{array}{l}\text { Gatvių išklotinès } \\
\text { suformuotos } \\
\text { (susiformavusios) }\end{array}$ & $\begin{array}{l}\text { Dominantė yra } \\
\text { svarbiausias } \\
\text { užstatymo struktūros } \\
\text { elementas }\end{array}$ & $\begin{array}{l}\text { Pastatų fasadų } \\
\text { plokštumose vyrauja } \\
\text { langų ir durų angos, } \\
\text { pagrindiniai įejimai ị } \\
\text { pastatus }\end{array}$ \\
\hline \multirow{2}{*}{$\begin{array}{l}\text { Vidutinè / aukšta } \\
4 \text { balai }\end{array}$} & Užbaigta. & Reikšminga. & Turinti ryškių ypatybių \\
\hline & $\begin{array}{l}\text { Gali būti pavienių } \\
\text { nebaigtų formuoti } \\
\text { gatvių išklotinių dalių }\end{array}$ & $\begin{array}{l}\text { Dominantè gali būti } \\
\text { matoma iš tam tikrų } \\
\text { erdvės taškų }\end{array}$ & $\begin{array}{l}\text { Gali būti aklinų sienų ir } \\
\text { kitų neperregimų } \\
\text { elementų pastatų } \\
\text { fasadų plokštumose }\end{array}$ \\
\hline \multirow[t]{2}{*}{$\begin{array}{l}\text { Vidutinè } \\
3 \text { balai }\end{array}$} & \multirow{2}{*}{$\begin{array}{l}\text { Vidutiniškai užbaigta. } \\
\text { Suformuotų ir } \\
\text { nesuformuotų gatvių } \\
\text { išklotinių dalys yra } \\
\text { apylygęs }\end{array}$} & \multirow{2}{*}{$\begin{array}{l}\text { Vidutiniškai } \\
\text { reikšminga. } \\
\text { Nėra dominantės, } \\
\text { tačiau nutolusios } \\
\text { dominantės gali būti } \\
\text { matomos iš tam tikrų } \\
\text { erdvės taškų }\end{array}$} & \multirow{2}{*}{$\begin{array}{l}\text { Neturinti ryškių } \\
\text { ypatybių. } \\
\text { Pastatų fasadų, kurių } \\
\text { plokštumose vyrauja } \\
\text { langų ir durų angos, ir } \\
\text { tokių, kurių } \\
\text { plokštumose nėra langu } \\
\text { ir pagrindinių ièjimų, } \\
\text { dalys yra apylygès }\end{array}$} \\
\hline & & & \\
\hline \multirow{2}{*}{$\begin{array}{l}\text { Žema / vidutinè } \\
2 \text { balai }\end{array}$} & \multirow{2}{*}{$\begin{array}{l}\text { Neužbaigta. } \\
\text { Visiškai suformuotos } \\
\text { tik pavienės gatvių } \\
\text { išklotinių dalys }\end{array}$} & Nereikšminga. & \multirow[b]{2}{*}{$\begin{array}{l}\text { Blanki. } \\
\text { Pastatų fasadų } \\
\text { plokštumose mažai } \\
\text { langų ir pagrindinių } \\
\text { ièjimų arba pastatų } \\
\text { fasadai nutolę nuo } \\
\text { gatvès }\end{array}$} \\
\hline & & $\begin{array}{l}\text { Nėra dominantės, } \\
\text { tačiau iš tam tikrų } \\
\text { erdvės taškų gali būti } \\
\text { matomi kiti } \\
\text { išraiškingi užstatymo } \\
\text { struktūros elementai }\end{array}$ & \\
\hline Žema & Neužbaigta. & Nereikšminga. & Blanki. \\
\hline 1 balas & $\begin{array}{l}\text { Vyrauja } \\
\text { nesuformuotos } \\
\text { (nesusiformavusios) } \\
\text { gatvių išklotinès }\end{array}$ & $\begin{array}{l}\text { Nèra dominantès, } \\
\text { vyrauja indiferentiški, } \\
\text { monotoniški } \\
\text { užstatymo struktūros } \\
\text { elementai }\end{array}$ & $\begin{array}{l}\text { Vyrauja aklini pastatų } \\
\text { fasadai arba aklinos } \\
\text { tvoros, mažai } \\
\text { pagrindinių iejimų i } \\
\text { pastatus }\end{array}$ \\
\hline
\end{tabular}


elementų atvirumo arba „permatomumo“46 lygio: erdvę formuojančių pastatų fasadų plokštumose vyraujančios langų ir durų angos (openings), taip pat ištisai istiklinti pastatų pirmieji aukštai (vitrinos), sudaro atvirumo ir permatomumo ispūdị bei gali padèti viešajai erdvei tapti gyvybingai ir intensyviai naudojamai.

Vykdant natūrinį tyrimą, gatvių, aikščių ir kitų viešujų erdvių pobūdį atspindinčios urbanistinès kompozicijos savybès įvertinamos lankantis vietoje: 1) urbanistinès kompozicijos užbaigtumas, reikšmingumas ir būdingumas vertinamas nuo 1 iki 5 balų; 2) remiantis minètais trimis kriterijais skirti balai sudedami; 3) atsižvelgiant ị vertinimo balų sumą, nagrinejjamo lokalaus centro vizualiai atskiros urbanistinès erdvès dalys skirstomos ị tris kategorijas. Pirmos, aukščiausios, kategorijos (vertinimo balų suma 11-15 balų) viešosios erdvès yra užbaigtos kompozicijos (savitos ir išsiskiriančios), jose yra dominante ir fasadų plokštumose vyrauja langų ir durų angos (vertinamas pirmojo aukšto lygyje esančių aklinų fasado plokštumų ir tokių, kuriose vyrauja angos, santykis). Antros kategorijos (6-10 balų) viešosioms erdvėms priskiriamos tos, kuriose vyrauja indiferentiški, monotoniški užstatymo struktūros elementai. Trečios kategorijos (3-5 balai) viešosios erdvès ribojasi su neužstatytais (pastatų neužimtais) plotais, jose vyrauja nesuformuotos (nesusiformavusios) gatvių išklotinės, aklini pastatų fasadai arba aklinos tvoros.

Užbaigtumas yra urbanistinès kompozicijos savybè, užtikrinanti gatvėvaizdžio bei miesto plano aiškumą ir tobulumą (remiamasi prielaida, kad užbaigtas gatvėvaizdis ir miesto planas neturi didelių trūkumų). Užbaigtos kompozicijos vizualiai atskiros urbanistinès erdvès dalys išsiskiria savo aiškiu suformavimu, t. y. gatvių išklotinès yra visiškai suformuotos (susiformavusios) ${ }^{47}$. Priešingai, dèl tam tikrų erdvés dalių urbanistinès kompozicijos netobulumo yra sunku

\footnotetext{
46 Terminą ,permatomumas“ (transparency) reikia suprasti ne tik siauraja prasme kaip galejjimą permatyti pastatą kiaurai, bet atsižvelgti ir i netiesioginę reikšmę - matyti suvokiant pastato vidaus erdvių ir gatvès erdvės ryšį (t. y. gatvės erdvėje esančiam žmogui turint galimybę pažvelgti ị pastato vidų ir suvokti, kad pro langus ir duris jis pats gali būti pastebètas iš pastato vidaus). Pagrindinių iejjimų įtaka yra ta, kad esant didesniam jų skaičiui tam tikroje gatvès atkarpoje yra daugiau galimybių atsitiktinai sutikti (encounter) iš pastatų išeinančius žmones. Galimybes būti pastebètam arba atsitiktinai sutikti žmones apibūdina gatvès erdvès natūralaus sekimo (natural surveillance) terminas arba, remiantis Jane Jacobs (1960), „eyes on the street“. ${ }^{47}$ Reikia pažymėti, kad nagrinèjant urbanistinę erdvę, palyginti su neurbanizuotu teritorijų kraštovaizdị vertinant taikomu erdvės uždarumo kriterijumi (Purvinas 1975), vizualiai atskiros urbanistinès erdvės dalies išbaigtumas priklauso nuo užstatymo struktūros elementų (šiuo atveju gamtiniai elementai nėra vertinami). Gatvès išklotinès yra nesuformuotos, jeigu dèl gamtinių ypatumų (reljefo, esamų želdynų ar kitų natūralių kliūčių) tam tikrose gatvès atkarpose nèra užstatymo struktūros elementų arba pastatai yra atitraukti nuo gatvès (pavyzdžiui, vyrauja neefektyviai naudojami žalieji plotai ir antžeminès automobilių stovèjimo aikštelès).
} 
susidaryti visai aiškų miesto ar jo dalies vaizdą. Jeigu yra tam tikrų nebaigtų formuoti gatvių išklotinių dalių ir viešoji erdvè ribojasi su neužstatytais (pastatų neužimtais) plotais, nors ir sudarančiais mažą procentinę dalị nuo viso gatvès išklotinių ilgio (pavyzdžiui, neefektyviai naudojamais žaliaisiais plotais arba antžeminèmis automobilių stovejjimo aikštelèmis), užbaigtumas ịvertinamas 4 balais. Jeigu suformuotų ir nesuformuotų gatvių išklotinių dalys yra apylygès (siekiant tikslumo, gatvès išklotinių ilgis matuojamas plane), užbaigtumas ivertinamas 3 balais. Urbanistinè kompozicija, kai gatvès išklotinè dèl gamtinių ypatumų (reljefo, esamų želdynų ar kitų natūralių kliūčių) suformuota tik vienoje pusèje (kitoje pusejje gali būti, pavyzdžiui, status šlaitas ar želdynų masyvas), taip pat paprastai įvardijama kaip vidutiniškai išbaigta. Kai visiškai suformuotos tik pavienès gatvių išklotinių dalys ar vyrauja nesuformuotos (nesusiformavusios) gatvių išklotinès, užbaigtumas įvertinamas atitinkamai 2 balais ir 1 balu.

Reikšmingumas arba svarbumas - tai viešosios erdvès ypatybè, kai tam tikra vieta turi didelę reikšmę dèl išsiskiriančio kompozicinès struktūros elemento (dominantės) poveikio ${ }^{48}$. Kai gatvès ašis veda tiesiai ị dominantę ir urbanistinę erdvę ribojantys užstatymo struktūros elementai neužstoja vaizdo, visada užtikrinamas vizualinis ryšys (žr. 2.8 paveikslą, 1 modeli, 1,2 ir 3 tipus), reikšmingumas ịvertinamas 5 balais, jeigu yra vizualinių kliūčių ir dominante gali būti matoma iš tam tikrų erdvés taškų - 4 balais. Nustatant, ar vizualiai atskira urbanistinès erdvès dalis yra reikšminga, neužtenka pažymèti faktą, kad dominanté, išsiskirianti aukščiu arba tūriu iš ją supančiu fono elementų, yra svarbiausias užstatymo struktūros elementas. Taip pat svarbu atsižvelgti i pastatų funkcijas, iš kurių svarbiausios - pirmos kategorijos - yra reprezentacinès (administracinè, religinè ir kitos valstybinès bei visuomeninès funkcijos) ir tokios, kurioms apibūdinti vartojamas aktyvios veiklos terminas (prekybos, maitinimo, paslaugu ir kitos funkcijos). Pavienių gyvenamųjų ir biurų aukštybinių bei tokių pastatų, kuriu pagrindinis ar kitas gerai matomas fasadas išsiskiria iš esamo užstatymo, funkcijos paprastai nèra priskiriamos pirmai kategorijai. Todèl tokių erdvès dalių, kuriose nèra pirmos kategorijos funkcijų, urbanistinè kompozicija gali būti ivardijama kaip vidutiniškai reikšminga arba nereikšminga. Jeigu dominante yra gretimoje viešojoje erdvejje ir gali būti matoma iš tam tikrų erdvès taškų (žr. 2.8 paveikslą, 2 modelį, 2 ir 3 tipus), reikšmingumas ịvertinamas 3 balais. Viešoji erdvé ịvardijama kaip nereikšminga šiais atvejais: kai nèra dominantès, tačiau iš tam tikrų erdvès taškų gali būti matomi kiti išraiškingi užstatymo struktūros elementai, reikšmingumas ịvertinamas 2 balais, kai vyrauja indiferentiški, monotoniški, niekuo neišsiskiriantys užstatymo struktūros elementai - 1 balu.

${ }^{48}$ Vienas iš gerai žinomų reikšmingos viešosios erdvės pavyzdžių - Piazza del Campo, Siena, Italija. 
Vertinant gatvių išklotines remiantis būdingumo kriterijumi (kai fasadai suformuoti vadovaujantis atvirumo arba ,permatomumo“ principu), svarbu ne tik nustatyti, ar pastatų fasadų plokštumose vyrauja langų ir durų angos, tačiau taip pat pažymèti pagrindiniu iejjimu i pastatus, kai kuriais atvejais ir vartu arba ìvažiavimu i ̣ sklypą (vidinị kiemą) $)^{49}$, vietas. Urbanistinès kompozicijos būdingumą daugiausia lemia architektūriniai erdvę ribojančiu pastatų sprendimai, užtikrinantys pastatų vidaus erdvių ir urbanistinès erdvès tarpusavio ryšị ir sudarantys sąlygas pastatą naudoti komercinei ar kitai numatytai veiklai. Tai leidžia sukurti intensyviai naudojamą ir palankią žmogui viešają erdvę - susitikimų ir bendravimo vietą. Kaip priešingybė siekiui užtikrinti atvirumo principo igyvendinimą, erdvę formuojantys aklini pastatų fasadai arba aklinos tvoros sudaro uždarumo ir nejaukumo ispūdį, ir tokiose urbanistinès erdvès dalyse nesukuriamos tinkamos sąlygos socialinei interakcijai. Apskritai galima pastebėti, kad palyginti su aukšto atvirumo arba „permatomumo“ lygio viešosiomis erdvėmis, kurios yra neatskiriamai susijusios su tradicine (istorine) miesto dalimi, sovietiniais metais suformuotus lokalius centrus sudarančios ryškių ypatybių turinčios viešosios erdvès yra reta išimtis. Jeigu pastatų fasadų plokštumose mažai langų ir pagrindinių iẻjimų ar gatvès erdvè išsidriekusi ir pastatų fasadai nutolę nuo gatvès (pavyzdžiui, pastatus nuo gatvès skiria žalieji plotai, antžeminès automobiliu stovèjimo aikštelès ir indiferentiški aklini fasadai ar tvoros), urbanistinė kompozicija yra blanki, būdingumas įvertinamas atitinkamai 2 balais ir 1 balu.

Kai kuriais atvejais urbanistinès kompozicijos netobulumas nèra kliūtis plètoti gatvių išklotines, ypač jeigu lokalų centrą sudarančiose vizualiai atskirose urbanistinès erdvès dalyse yra dominante ir pastatų fasadų plokštumose vyrauja langų ir durų angos. Tokių neužbaigtų viešujų erdvių galimybes tapti gyvybingomis ir intensyviai naudojamomis gali padidinti pastatų architektūros tobulinimas ir viešųų erdvių kokybei poveikị turinčių priemonių taikymas, pavyzdžiui, pastatų pirmuosiuose aukštuose esančiu patalpų išplètimas, statant naujus priestatus, ir naujų pastatų, kurių fasadai būtų nukreipti ị gatvès erdvę, iterpimas. Šeškinès, Fabijoniškių ir Pašilaičių lokalių centrų gatvių išklotinių formavimo trūkumai ir galimybès pateikiamos 2.15-2.17 lentelèse. Kitos rekomendacijos, nustatant lokalių centrų urbanistinès struktūros formavimo principus, pateikiamos trečiajame skyriuje.

${ }^{49}$ Perregimi vartai, ypač jeigu jais naudojasi ne tik atvykstantieji automobiliu, bet ir pėstieji (pavyzdžiui, pagrindinio įvažiavimo, kuriuo galima patekti ị gyvenamųų ar mišrios paskirties pastatų komplekso teritoriją), turi įtakos žmonių srautams tam tikroje gatvès atkarpoje. Priešingai, viešoji erdvė, kurioje vyrauja aklini ịvažiavimų i garažus ar požemines automobilių stovejjimo aikšteles vartai ir aklinos sienos, turi mažai galimybių tapti gyvybinga ir intensyviai naudojama. 
2.15 lentelè. Šeškinès lokalaus centro gatvių išklotinių formavimo trūkumai ir galimybès Table 2.15. Weaknesses and opportunities of the formation of street elevations in the local centre of Šeškinè

\begin{tabular}{|c|c|}
\hline Trūkumai & Galimybès \\
\hline $\begin{array}{l}\text { Šeškinės ir Ukmergès gatvėse yra daug } \\
\text { neišnaudotu, neaiškios paskirties } \\
\text { urbanistinės erdvės dalių, kuriose vyrauja } \\
\text { aklini pastatų fasadai, automobilių } \\
\text { stovejjimo aikštelės ir ūkiniai kiemai }\end{array}$ & $\begin{array}{l}\text { Lokalaus centro potencialas gali būti geriau } \\
\text { išnaudojamas nauju pastatų fasadus nukreipiant } \\
\text { i gatvès erdvę, užstatant neišnaudotas erdves ir } \\
\text { esamas automobilių stovejimo aikšteles, } \\
\text { pastarąsias įrengiant daugiaaukščiuose } \\
\text { priestatuose kvartalo viduje arba po žeme }\end{array}$ \\
\hline
\end{tabular}

2.16 lentelè. Fabijoniškių lokalaus centro gatvių išklotinių formavimo trūkumai ir galimybès

Table 2.16. Weaknesses and opportunities of the formation of street elevations in the local centre of Fabijoniškès

\begin{tabular}{|c|c|}
\hline Trūkumai & Galimybès \\
\hline $\begin{array}{l}\text { Fabijoniškių lokalaus centro dalies, } \\
\text { esančios gyvenamojo rajono viduje, } \\
\text { pėsčiųjų takų išklotinės nėra visiškai } \\
\text { suformuotos, didelių atvirų erdvių paskirtis } \\
\text { nėra aiški. Kitos dalies - savaime } \\
\text { besiformuojančios abipus S. Stanevičiaus } \\
\text { gatvės - pastatai yra atitraukti nuo gatvės, } \\
\text { pagrindiniai iejimai įrengti šoniniuose } \\
\text { fasaduose. Gatvės erdvejje vyrauja reljefo } \\
\text { šlaitai, aklinos garažų paskirties pastatų } \\
\text { plokštumos ir automobilių stovejjimo } \\
\text { aikštelès }\end{array}$ & $\begin{array}{l}\text { S. Stanevičiaus gatvejje esančioje Fabijoniškių } \\
\text { lokalaus centro dalyje įterpiant naujus pastatus, } \\
\text { kurių fasadai būtų nukreipti i gatvès erdvę, ir } \\
\text { ties viešojo transporto stotelemis esančioje } \\
\text { sankryžoje suformuojant pagrindinę lokalaus } \\
\text { centro viešają erdvę, būtų sudarytos tinkamos } \\
\text { sąlygos pėstiesiems. Gyvenamojo rajono viduje } \\
\text { esanti lokalaus centro dalis gali būti plètojama } \\
\text { pertvarkant užstatymo struktūros elementus ir iš } \\
\text { naujo suformuojant aplink komercinių pastatų } \\
\text { kompleksą išsidèsčiusias viešąsias erdves }\end{array}$ \\
\hline
\end{tabular}

2.17 lentelè. Pašilaičių lokalaus centro gatvių išklotinių formavimo trūkumai ir galimybès

Table 2.17. Weaknesses and opportunities of the formation of street elevations in the local centre of Pašilaičiai

\begin{tabular}{|c|c|}
\hline Trūkumai & Galimybès \\
\hline $\begin{array}{l}\text { Lokalų centrą supančios nesuformuotos } \\
\text { viešosios erdvės bei aklinos prekybos ir } \\
\text { paslaugų įmonių ūkinių kiemų tvoros, } \\
\text { pasitinkančios iš rytų ir vakaru pusès } \\
\text { atvykstančius lankytojus, turi neigiamos } \\
\text { itakos ì lokalų centrą vedančių gatvių ir } \\
\text { pésčiųjų takų gyvybingumui }\end{array}$ & $\begin{array}{l}\text { Urbanistinę erdvę ribojančių pastatų } \\
\text { architektūriniai sprendimai ir urbanistinės } \\
\text { aplinkos kokybė turi įtakos galimybėms } \\
\text { padidinti lokalaus centro lankomumą. Tai } \\
\text { galima pasiekti perplanavus ì lokalų centrą } \\
\text { vedančias gatves ir pésčiujjų takus bei numačius } \\
\text { vietas naujiems pastatams, kurių pirmuosiuose } \\
\text { aukštuose būtų vykdoma aktyvi veikla, } \\
\text { viršutiniuose vyrautu gyvenamoji funkcija }\end{array}$ \\
\hline
\end{tabular}




\subsubsection{Kompozicinès struktūros tyrimo išvados}

Istorinèse (savaime susiformavusiose) miestų dalyse dominantès paprastai yra glaudžiai susijusios su miesto plano struktūra. Urbanistinei kompozicijai didelę reikšmę turinčios dominantès sovietiniais metais buvo išdèstomos remiantis meniniais principais, siekiant pagyvinti monotonišką gyvenamujų rajonų vaizdą. Todèl būtina iš naujo ịvertinti jų vietą ir vaidmenị, priklausantị nuo dominantés ir jos vizualinių ryšiu pobūdžio bei urbanistinę erdvę ribojančių užstatymo struktūros elementų išsidèstymo. Taikant reikšmingumo arba užstatymo struktūros elementų santykinès svarbos kriterijų, urbanistinę kompoziciją siūloma vertinti remiantis trimis îvardytais kompozicinių ašių ir dominančių tarpusavio ryšių tipais.

Vykdant natūrinị tyrimą, Šeškinès, Fabijoniškių ir Pašilaičių lokalius centrus sudarančiu viešųų erdvių pobūdị atspindinčios urbanistinès kompozicijos savybès - užbaigtumas, reikšmingumas ir būdingumas - įvertintos lankantis vietoje. Vyraujantys nagrinètų lokalių centru gatvių išklotinių trūkumai - nesuformuotos viešosios erdvès bei aklinos pastatų plokštumos, prekybos ir paslaugu imonių ūkinių kiemų tvoros, automobilių stovejjimo aikštelès. Taip pat reikia išskirti nuo gatvès atitrauktų pastatų neigiamą ịtaką gyvybingoms viešosioms erdvèms. Minèti veiksniai yra vieni iš pagrindinių, lemiančių lokalius centrus sudarančių viešųjų erdvių palankumą žmonių judejjimui pésčiomis ir naudojimo intensyvumą. Svarbiausios įvardytos galimybès yra užstatymo struktūros elementų pertvarkymas - naujų pastatų fasadų nukreipimas ị gatvès erdvę, užstatant neišnaudotas erdves ir esamas automobilių stovejjimo aikšteles, bei urbanistinę erdvę ribojančių pastatų architektūrinių sprendimų ir urbanistinès aplinkos kokybès gerinimas.

\subsection{Funkcinès ir kompozicinès struktūrų sąveikos tyrimo duomenų mokslinè sintezè}

Šiame skyrelyje yra stengiamasi sujungti funkcinius ir kompozicinius urbanistinès struktūros analizès aspektus - lokalių centru vietos ir vaidmens lokaliu ir globaliu lygmeniu nustatymo bei viešųų erdvių pobūdị atspindinčio urbanistinès kompozicijos savybių ịvertinimo. Pasirinkta tyrimo kryptis yra aktuali dèl būtinybės tobulinti sovietinių metų statybos Lietuvos didmiesčių gyvenamujjų rajonų urbanistinę struktūrą (nustačius trečios kategorijos urbanistinę kompoziciją esminiai pokyčiai yra neišvengiami). Taikant pavienes industrinès statybos laikotarpio pastatų atnaujinimo ir urbanistinès aplinkos kokybès gerinimo priemones - sutelkiant dèmesị i pastatų energinio naudingumo didinimą, fasadų apdailos sprendimus, plečiant automobilių stovèjimo aikšteles, sodinant naujus želdi- 
nius, įrengiant pėsčiujų takus ir atnaujinant kitus gyvenamosios aplinkos elementus - iš esmès nèra sprendžiamos šios aktualios problemos: funkcijų atskyrimas, vyraujanti gyvenamoji funkcija ir aktyvios veiklos židinių, kuriuose sutelktos paslaugos ir darbo vietos, trūkumas, viešujų ir privačių erdvių susipynimas, viešojo transporto, pėsčiujų ir automobilių eismo suderinamumas (pavyzdžiui, teikiant pirmenybę judejjimui pésčiomis ne visada užtikrinamas pésčiųų zonų gyvybingumas), kai ignoruojamos dèl to kylančios socialinès ir ekonominès pasekmès (pavyzdžiui, apribotos bendravimo galimybès (socialinè interakcija), didelę procentinę dalị iš visų transporto rūšių, pasirenkamų keliaujant į kasdienius poreikius tenkinančius objektus ir darbo vietas, sudarantis lengvojo automobilio naudojimas, kasdieniams poreikiams tenkinti keliaujant didelius atstumus, ir tokioms kelionèms sugaištamas laikas) ir kitos problemos. Vertinant urbanistinès erdvès formavimo trūkumus reikia išskirti gatvès erdvès išsidriekimą, kai, remiantis modernistinio (laisvojo) planavimo principais, buvo siekiama atitraukti pastatų fasadus nuo važiuojamosios dalies. Vyravęs klaidingas požiūris ị mieste vykstančius procesus, sukuriant atskiras erdves nepertraukiamam automobilių judejjimui ir péstiesiems skirtas „zonas“ (tikslingai suplanuotas ir skirtas susitikti, bendrauti, keistis kuo nors), t. y. klaidinga nuostata, kad šios istorinès gatvès paskirtys gali egzistuoti atskirai, yra viena iš svarbiausių šiame moksliniame darbe keliamus sovietiniais metais suprojektuotų lokalių centrų trūkumus nulèmusių priežasčių, kurią galima geriau suprasti nagrinëjant aktualius pavyzdžius.

Suvedant gautus funkcinès ir kompozicinès struktūrų tyrimų rezultatus, išskiriami atvejai, kada lokalų centrą sudarančios viešosios erdvès turi galimybes tapti gyvybingomis ir intensyviai naudojamomis. Siekiama ịvertinti suplanuotu gyvenamujų rajonų centrų, išsiskiriančių tuo, kad juose esantys pastatai pritaikyti kasdieniams žmonių poreikiams tenkinti, funkcijų ir miesto plano struktūros ryši, t. y. patikrinti, ar sutampa suplanuotų gyvenamujų rajonų traukos objektų - nuo žmonių judejjimo priklausančių prekybos, viešojo maitinimo ir kitų kasdienes paslaugas teikiančių įmonių - išsidèstymas (distribution of active land uses) ir nagrinejjami svarbiausi viešujų erdvių tinklo struktūros elementai (the dominant elements of the urban grid).

Siekiant geriau suprasti funkcinès ir kompozicinès struktūrų tyrimu rezultatus ir îvertinti jų panaudojimo galimybes, yra tikslinga išsamiai išanalizuoti po du kiekvieną nagrinejjamą lokalų centrą kertančius maršrutus: Šeškinèje - dvi lokalaus centro dalis jungianti pèsčiųjų taką ir Šeškinès gatvès atkarpas, Fabijoniškių lokalaus centro dalis kertančius maršrutus S. Stanevičiaus gatvės atkarpas ir pėsčiujų taką gyvenamojo rajono viduje, Pašilaičiuose - Žemynos gatvès atkarpas ir lokalų centrą su Laisvès prospektu jungianti pésčiujų taką. Svarbiausias kriterijus pasirenkant maršrutus - juos sudarančių viešųjų erdvių palankumas žmonių judejjimui pėsčiomis. Vienas iš 
dviejų pasirinktų maršrutų nagrinejjamuose lokaliuose centruose yra skirtas tik péstiesiems, kitas - ir péstiesiems, ir automobiliais atvykstantiems lankytojams. Pavyzdžiui, Ukmergès gatve besidriekiantis maršrutas nebuvo nagrinètas, nes pèstiesiems prieinama tik viena nedidelè maršruto atkarpa, o kitose atkarpose nèra įrengtų šaligatvių.

Minètų maršrutų urbanistinès kompozicijos ịvertinimai ir pasiekiamumo rodikliai pateikiami lentelèse ir diagramose (C priedas). Pridedamas trumpas nagrinèjamų maršrutų skiriamųjų ypatybių aprašas.

- 1 maršrutas (Šeškinès gatvès atkarpos). Šeškinès gatvès urbanistinès kompozicijos ịvertinimai yra žemi. Išimtis - gatvès atkarpa, kurioje suformuotas ištisinis užstatymas naujais pastatais (B priedas, B11 pav.). Pasiekiamumo rodikliai yra aukštesni prie sankryžos su Ukmergès gatve ir tolygiai žemejja judant lokalaus centro pakraščiu. Žemiausi pasiekiamumo lokaliu ir globaliu lygmeniu rodikliai yra pagal Šeškinès turgų besidriekiančios maršruto atkarpos.

- 5 maršrutas (2.9 ir 2.10 pav.). Gerai pasiekiamos lokalų centrą sudarančios viešosios erdvès yra pirmos ir antros kategorijos. Išimtis - Ukmergès gatvę kertanti maršruto atkarpa (B priedas, B6 pav.), priskirta trečiai kategorijai. Šeškinès turgu kertančios maršruto atkarpos pasiekiamumas lokaliu ir globaliu lygmeniu žemiausias, tačiau viešoji erdvė priskirta pirmai kategorijai (B priedas, B13 pav.).

- 13 maršrutas (S. Stanevičiaus gatvès atkarpos). Urbanistinès kompozicijos įvertinimai ir viešujų erdvių pasiekiamumo rodikliai yra apylygiai visose nagrinejjamą lokalų centrą kertančios gatvès atkarpose (gatvès pradžios atkarpu pasiekiamumo vertės šiek tiek aukštesnès). Dèl vyraujančių aklinų pastatų fasadų, reljefo, neefektyviai naudojamų žaliujų plotų ir antžeminių automobilių stovejjimo aikštelių, vertinant viešujų erdvių kokybę, skirti žemi išraiškingumo ir būdingumo ịvertinimai - visa S. Stanevičiaus gatve priskirta trečiai kategorijai.

- 15 maršrutas (2.11 ir 2.12 pav.). Lokalaus centro pakraščio bei už centro ribų esančių viešujų erdvių ir urbanistinès kompozicijos įvertinimai, ir pasiekiamumo rodikliai yra žemi. Priartejjus prie svarbių traukos objektų, urbanistinès kompozicijos įvertinimai aukštesni, pagrindinis pėsčiųjų takas - antros kategorijos (B priedas, B24 pav.). Pèstiesiems skirto koridorių primenančio praejimo pasiekiamumo vertès aukščiausios, tačiau viešoji erdvè priskirta antrai kategorijai dèl žemų reikšmingumo ir būdingumo įvertinimų (B priedas, B22 pav.).

- 25 maršrutas. Urbanistinès kompozicijos ịvertinimai ir viešujų erdvių pasiekiamumo rodikliai yra apylygiai visose Žemynos gatvès atkarpose. I lokalų centrą vedanti atkarpa išsiskiria aukštesnèmis pasiekiamumo 
vertèmis (B priedas, B33 pav.). Lokalų centrą sudarančios viešosios erdvès pasiekiamumo vertès yra žemiausios (B priedas, B34 pav.). Viešujų erdvių kokybei ịtakos turi neišraiškinga ir blanki urbanistinè kompozicija - visos maršrutą sudarančios viešosios erdvès priskirtos trečiai kategorijai.

- 26 (29) maršrutas (2.13 ir 2.14 pav.). Palyginti su lokalaus centro pakraščio ir už centro ribų esančiomis viešosiomis erdvemis, pasiekiamumo rodikliai yra šiek tiek aukštesni priartejus prie svarbių traukos objektų. Tik pesčiųu judejimui skirtoje viešojoje erdvejje vyrauja aklini pastatu fasadai ir aklinos tvoros. Neefektyviai naudojami žalieji plotai ribojasi su antžeminèmis automobilių stovejjimo aikštelèmis. I lokalų centrą vedantis pėsčiujų takas priskirtas trečiai kategorijai.

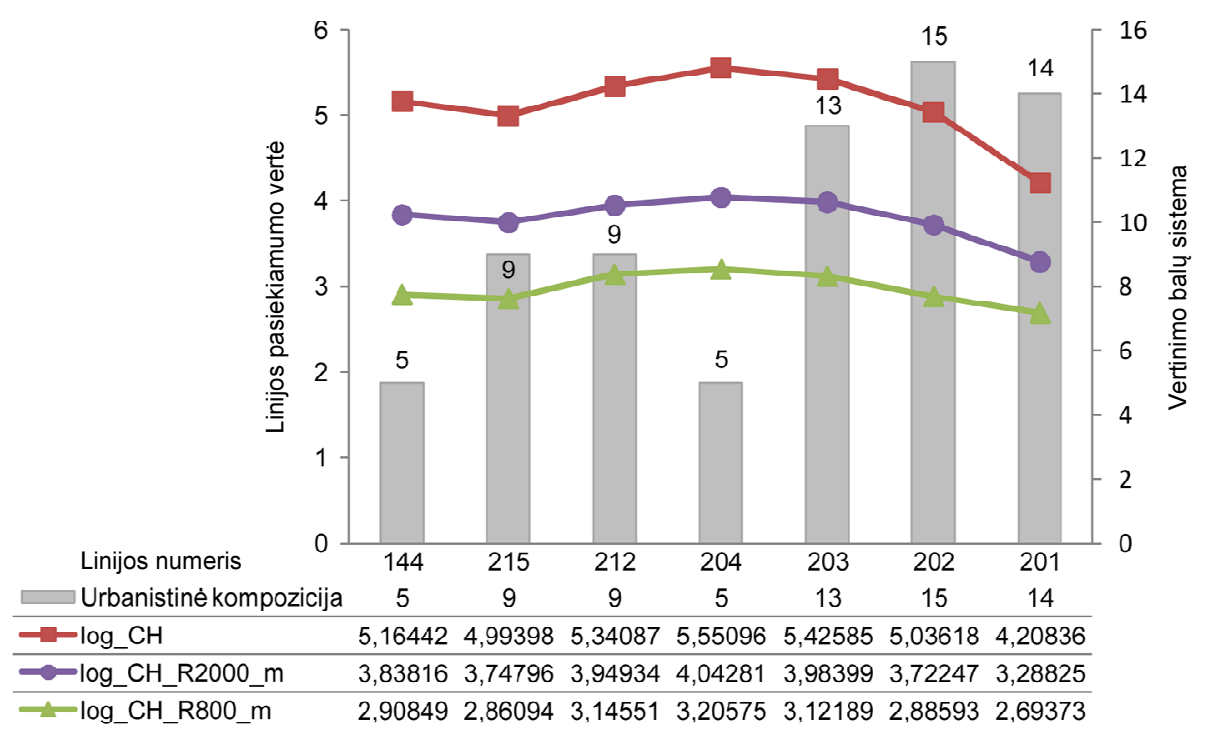

2.9 pav. Šeškinès lokalaus centro 5 maršrutą sudarančiu atkarpų urbanistinès kompozicijos ir viešujų erdvių pasiekiamumo (pasirinkimo, ịvertinant mažiausią posūkio kampą) $800 \mathrm{~m}, 2000 \mathrm{~m}$ ir neapibrèžtu spinduliu tarpusavio priklausomybės diagrama

Fig. 2.9. Diagram showing interdependence between urban composition and spatial accessibility (segment angular choice radius $800 \mathrm{~m}, 2000 \mathrm{~m}, \mathrm{n}$ ) of the route 5 in the local centre of Šeškinè 

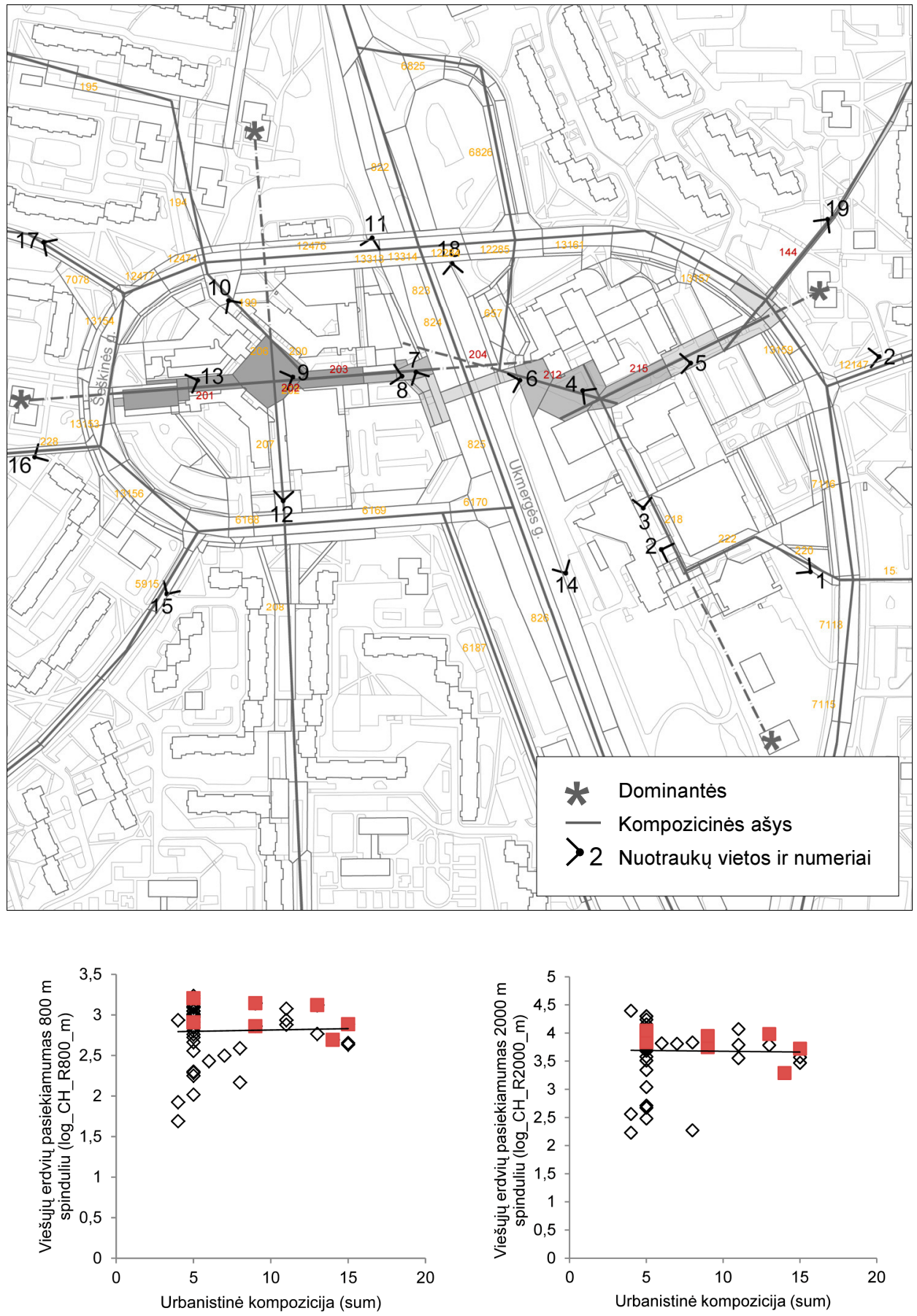


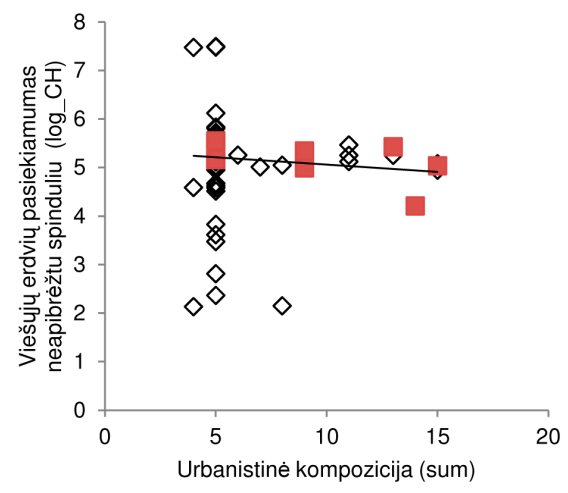

2.10 pav. Šeškinès lokalaus centro 5 maršrutą sudarančių atkarpų (žymimos raudonai) urbanistinès kompozicijos ir viešujų erdvių pasiekiamumo (pasirinkimo, ịvertinant mažiausią posūkio kampą) 800 m, $2000 \mathrm{~m}$ ir neapibrèžtu spinduliu tarpusavio priklausomybès taškinès diagramos

Fig. 2.10. Scattergrams between urban composition and spatial accessibility (segment angular choice radius $800 \mathrm{~m}, 2000 \mathrm{~m}, \mathrm{n}$ ) of the route 5 in the local centre of Šeškinè (the lines of the route marked in red)

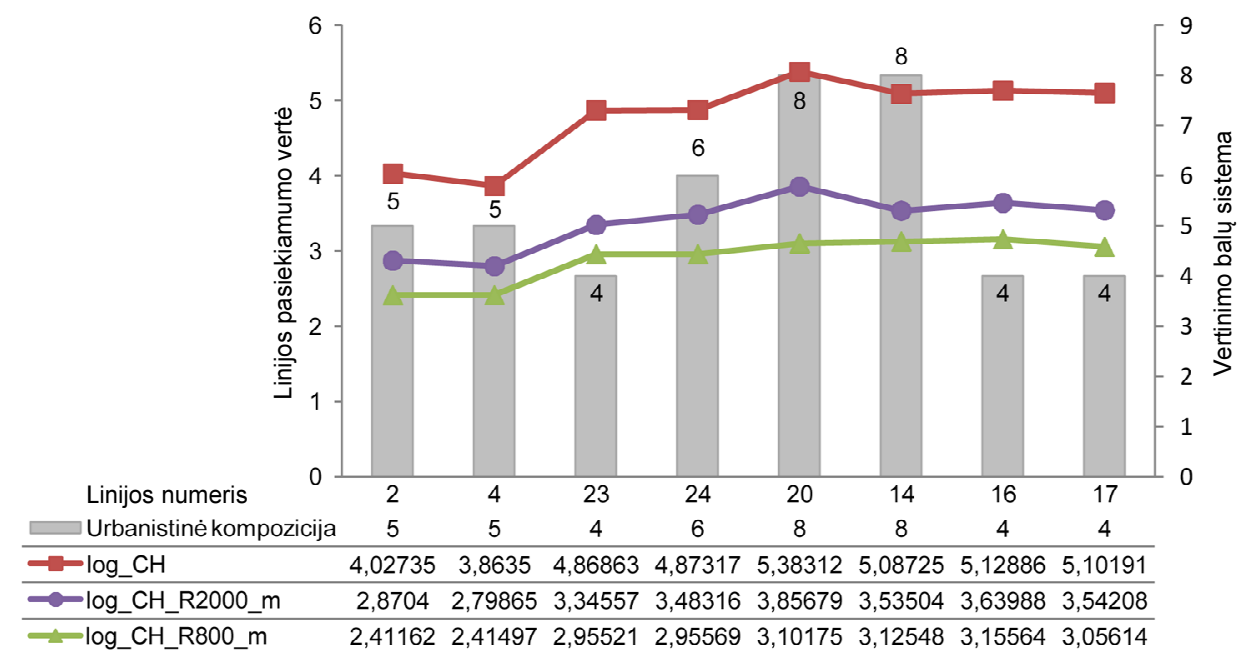

2.11 pav. Fabijoniškių lokalaus centro 15 maršrutą sudarančių atkarpų urbanistinès kompozicijos ir viešujų erdvių pasiekiamumo (pasirinkimo, ịvertinant mažiausią posūkio kampą) $800 \mathrm{~m}, 2000 \mathrm{~m}$ ir neapibrèžtu spinduliu tarpusavio priklausomybės diagrama Fig. 2.11. Diagram showing interdependence between urban composition and spatial accessibility (segment angular choice radius $800 \mathrm{~m}, 2000 \mathrm{~m}, \mathrm{n}$ ) of the route 15 in the local centre of Fabijoniškès 

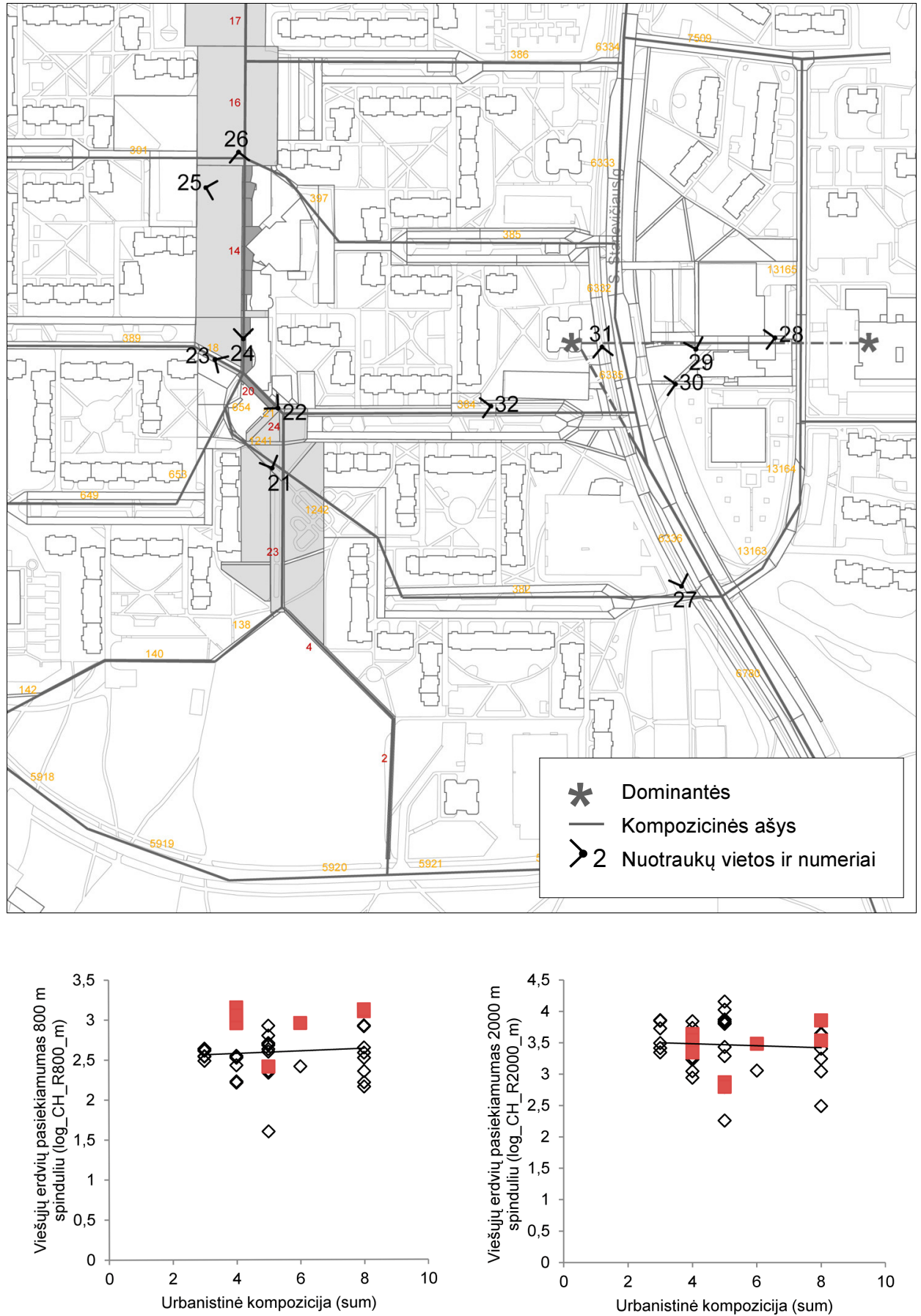


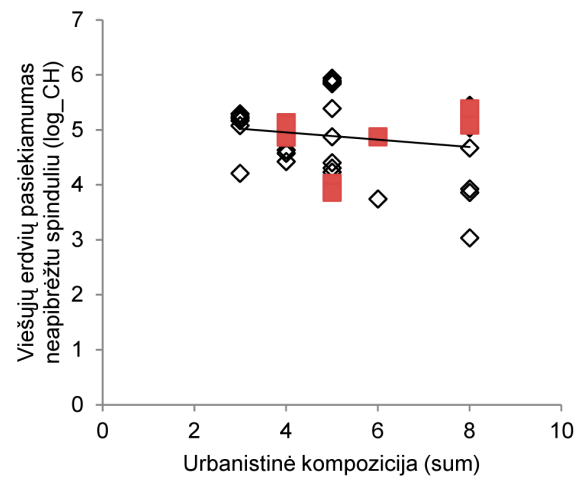

2.12 pav. Fabijoniškių lokalaus centro 15 maršrutą sudarančių atkarpų (žymimos raudonai) urbanistinès kompozicijos ir viešujų erdvių pasiekiamumo (pasirinkimo, ịvertinant mažiausią posūkio kampą) 800 m, 2000 m ir neapibrèžtu spinduliu tarpusavio priklausomybės taškinès diagramos

Fig. 2.12. Scattergrams between urban composition and spatial accessibility (segment angular choice radius $800 \mathrm{~m}, 2000 \mathrm{~m}, \mathrm{n}$ ) of the route 15 in the local centre of Fabijoniškès (the lines of the route marked in red)

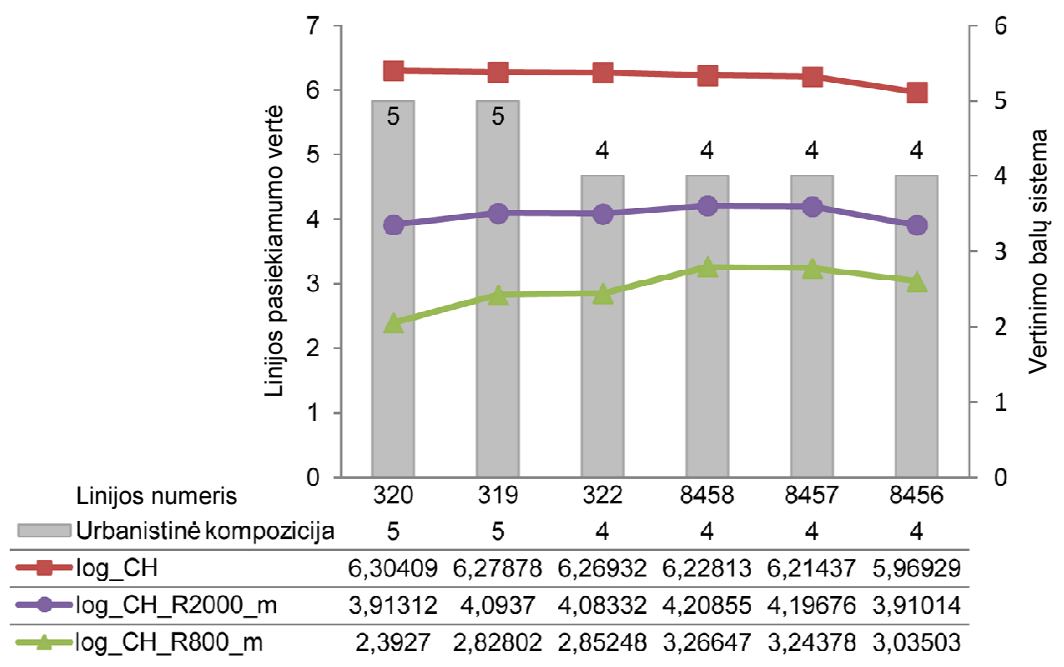

2.13 pav. Pašilaičių lokalaus centro 26 (29) maršrutą sudarančių atkarpų urbanistinès kompozicijos ir viešujų erdvių pasiekiamumo (pasirinkimo, ịvertinant mažiausią posūkio kampą) 800 m, $2000 \mathrm{~m}$ ir neapibrèžtu spinduliu tarpusavio priklausomybès diagrama Fig. 2.13. Diagram showing interdependence between urban composition and spatial accessibility (segment angular choice radius $800 \mathrm{~m}, 2000 \mathrm{~m}, \mathrm{n}$ ) of the route $26(29)$ in the local centre of Pašilaičiai 

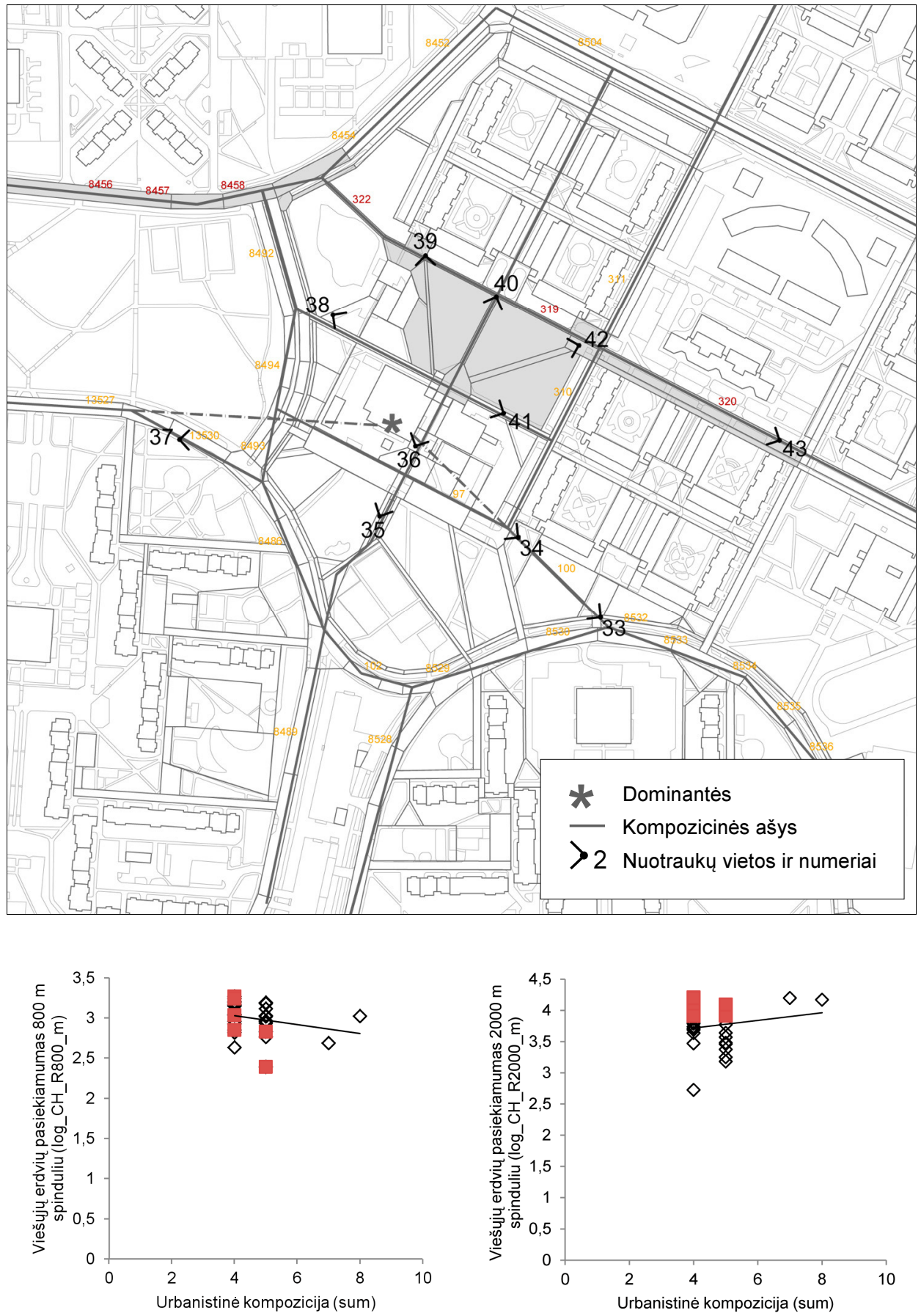


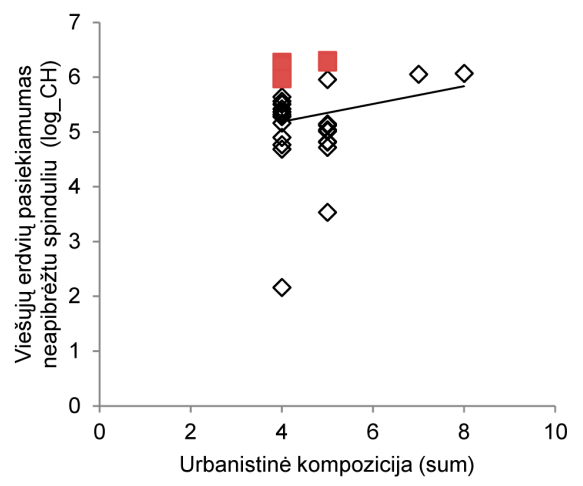

2.14 pav. Pašilaičių lokalaus centro 26 (29) maršrutą sudarančių atkarpų (žymimos raudonai) urbanistinès kompozicijos ir viešųų erdvių pasiekiamumo (pasirinkimo, ịvertinant mažiausią posūkio kampą) 800 m, 2000 m ir neapibrèžtu spinduliu tarpusavio priklausomybès taškinès diagramos

Fig. 2.14. Scattergrams between urban composition and spatial accessibility (segment angular choice radius $800 \mathrm{~m}, 2000 \mathrm{~m}, \mathrm{n}$ ) of the route 26 (29) in the local centre of Pašilaičiai (the lines of the route marked in red)

Apibendrinus gautus rezultatus, galima daryti išvadą, kad urbanistinès kompozicijos įvertinimas remiantis trimis pagrindiniais - užbaigtumo, reikšmingumo ir būdingumo - kriterijais ne tik padeda palyginti tam tikro lokalaus centro vizualiai atskiras urbanistinès erdvès dalis, bet ir leidžia atskleisti greta esančių lokalių centrų meninio ir vizualinio potencialo skirtumus. Aukštesni įvertinimai reiškia efektyviai išnaudojamas viešujų erdvių plètojimo galimybes. Žemiausi ivvertinimai rodo poreikị atsižvelgti i viešujų erdvių pasiekiamumo rodiklius ir ieškoti urbanistinès kompozicijos, įtraukiant dominančių, kompozicinių ašių ir mazgų išdèstymą, tobulinimo sprendimų. Nustačius nagrinèjamų lokalių centrų vizualiai atskirų urbanistinès erdvès dalių kategorijas, yra tikslinga apibendrinti jų ypatybes, viešųų erdvių pobūdį atspindinčias schemas pateikti grafiškai ir, jomis remiantis, analizuoti funkcinès ir kompozicinès struktūrų elementu išsidèstymą, tarpusavio ryšius ir tarpusavio priklausomybę.

Remiantis visų trijų nagrinètų lokalių centrų tyrimų duomenimis, galima pateikti keletą esamų funkcijų išsidèstymo ir urbanistinès kompozicijos prieštaringumų arba neatitikimų, kurių išvengti įmanoma laikantis bendrai priimtinų plètros principų ir tradicijų arba urbanistinio projektavimo proceso metu atsižvelgiant ị funkcinès ir kompozicinès struktūrų elementų sąveiką, pasireiškiančią per šių struktūrų elementų išsidèstymą, tarpusavio ryšius ir tarpusavio priklausomybę. Kai yra dominantè, tačiau neužtikrintas urbanistinès kompozicijos užbaigtumas ir būdingumas, tokioje urbanistineje erdvejje paprastai savaime 
susidaro sąlygos vyrauti automobilių transportui ir, iš esmès nepertvarkius urbanistinès struktūros, yra sunku sukurti tinkamas sąlygas socialinei interakcijai. Šis prieštaringumas yra pastebimas visuose nagrinètuose lokaliuose centruose. Kitas trūkumas - nesuformuoti svarbūs kompoziciniai mazgai, vadinamieji vartai i lokalu centrą (gateways to the local centre). Taikant reikšmingumo kriteriju, svarbiomis viešosiomis erdvèmis įvardijamos gatvių sankirtos, iš kurių matoma vertikali ar horizontali dominantè. Tokie savo aiškiu suformavimu (urbanistinès kompozicijos užbaigtumu ir būdingumu) išsiskiriantys kompoziciniai mazgai gali atsirasti pertvarkius Šeškinès ir Fabijoniškių lokalius centrus sudarančias viešąsias erdves, tobulinant esamus užstatymo struktūros elementus, statant naujus pastatus ir įrengiant šviesoforais reguliuojamas arba sulètinto eismo sankryžas, vadinamąsias bendres (shared space), t. y. bendrai naudojamas gatvès erdvès dalis, kuriomis laisvai juda péstieji, dviratininkai, automobiliai ir viešasis transportas. Norint sukurti vadinamuosius vartus ị Pašilaičių lokalų centrą, būtina atsižvelgti i viešųų erdvių tinklo struktūros formavimo bei pėstiesiems, dviratininkams ir automobiliais atvykstantiems lankytojams pritaikytos infrastruktūros trūkumus ir ịvertinti lokalų centrą supančio gatvių tinklo pertvarkymo (perplanavimo) galimybes.

\subsection{Antrojo skyriaus išvados}

1. Remiantis space syntax metodika parengto viešujų erdvių pasiekiamumo modelio analize parodè, kad pasitelkus matematinio ir grafinio modeliavimo priemones nustatyti urbanistinès struktūros ypatumai yra glaudžiai susiję su įvairių lygmenų centrų bei subcentrų išsidèstymu mieste ir gali būti objektyvus pagrindas tiriant suplanuotų funkcijų ir esamos struktūros galimybių ryši arba neatitikimą. Ši metodika yra aktuali nagrinejjant su lokalių centrų vieta ir vaidmeniu susijusias problemas, ypač sprendžiant sovietinių metų statybos Lietuvos didmiesčių gyvenamujų rajonų urbanistinès struktūros pertvarkymo klausimus.

2. Nagrinejjant Vilniaus centrų urbanistinès erdvès konfigūraciją, nepastebèta ryškaus viešuju erdvių tinklo sutankèjimo. Aukštesnis pralaidumo (gatvių tinklo „susisiekiamumo“) rodiklis yra Vilniaus senamiestyje, Žvėryne (abipus Sèliu gatvès) ir Žalgirio gatvejje. Vidurinèje dalyje sovietiniais metais suformuotu gyvenamujų rajonu ypatybė - retas gatvių tinklas ir pakankamai tankus pésčiujjų takų, vedančių i lokalų centrą, tinklas. Dèl šios priežasties, taip pat ir dèl viešujų ir privačių erdvių susipynimo iškyla sunkumų nustatant tinkamiausias vietas lokaliems centrams plètoti. 
3. Prielaida, kad centrų formavimąsi lemia lokalių ir globalių urbanistinès erdvès savybiu sutapimas, geriausiai pasitvirtino Vilniaus centrineje dalyje (senamiestyje, Gedimino prospekte, iš dalies naujajame miesto centre ir Žverryne). Iš sovietiniais metais suformuotų centrų aukščiausi yra Šeškinès centro pasiekiamumo rodikliai, kiti vidurinejje dalyje esantys lokalūs centrai (Ukmergès gatvès ašyje esantys Fabijoniškių ir Pašilaičių bei išsidèstę abipus Laisvès prospekto ir Ateities gatvès) taip pat yra svarbūs, bet jų urbanistinè struktūra turi būti tobulinama, gerinant pasiekiamumą lokaliu lygmeniu.

4. Atsižvelgiant $\mathfrak{i}$ aukštus pasiekiamumo rodiklius nustatytos vietos naujiems centrams plètoti ir esami centrai, kurie gali būti stiprinami. Reikètų išskirti Žalgirio gatvę, Zarasų ir Subačiaus gatvių transporto mazgą (centrinejje dalyje), Savanorių prospekto žiedą ir Nemenčinès plento pradžioje esantị transporto mazgą (vidurinèje dalyje). Periferinèje dalyje preliminariai galima išskirti potencialias vietas Pilaiteje (vieta turi būti tikslinama atsižvelgiant ị gyvenamujų kvartalų plètrą), Balsiuose (Žaliųjų Ežeru gatvès atkarpoje) ir Liepkalnyje (Liepkalnio gatvèje ir Minsko plento pradžioje).

5. Šeškinès lokalaus centro gyvybingumą ir patrauklumą lankytojams galima būtų paaiškinti tuo, kad jo integracijos ir pasirinkimo - galimybès būti kelionès tikslu arba maršruto dalimi - rodikliai yra aukšti, t. y. jo vieta yra svarbi ir viso miesto mastu, ir aplink esančių viešujų erdvių kontekste. Fabijoniškių ir Pašilaičių lokalūs centrai yra „,pasislèpę“ gyvenamujų rajonų viduje ir gali būti ịvardijami tik kaip kelionès tikslas, bet ne kaip kelionès iš tam tikros vietos ị kitą pasirinktą vietą mieste dalis (t. y. juos sudarančios viešosios erdvès nèra naudojamos pravažiuoti ar pereiti vykstant iš vienos miesto dalies ị kitą).

6. Šeškinès ir Pašilaičių lokalių centrų viešųjų erdvių pasiekiamumo vidutinès vertès yra aukštesnès nei Fabijoniškių. Nors Pašilaičių lokalus centras, remiantis gautomis vidutinėmis vertèmis, gali būti ịvardytas kaip geriausiai pasiekiamas $800 \mathrm{~m}, 2000 \mathrm{~m}$ spinduliu ir viso miesto mastu, tačiau Šeškinès lokalus centras išsiskiria aukščiausiomis vertemis, ypač vertinant Ukmergès gatvès pasiekiamumą $2000 \mathrm{~m}$ ir neapibrèžtu spinduliu.

7. Apibendrinus gautus rezultatus nustatyta, kad urbanistinès kompozicijos ivvertinimas remiantis trimis pagrindiniais - užbaigtumo, reikšmingumo ir būdingumo - kriterijais padeda palyginti tam tikro lokalaus centro vizualiai atskiras urbanistinès erdvès dalis ir atskleisti greta esančių lokalių centrų meninio ir vizualinio potencialo skirtumus. Aukštesni ịvertinimai reiškia efektyviai išnaudojamas viešujų erdvių plètojimo galimy- 
bes. Žemiausi ịvertinimai rodo poreikị atsižvelgti ị viešųų erdvių pasiekiamumo rodiklius ir ieškoti urbanistinès kompozicijos, itraukiant dominančių, kompozicinių ašių ir mazgų išdèstymą, tobulinimo sprendimų. 


\section{Lokalių centrų urbanistinės struktūros formavimo principai}

Antrajame skyriuje, naudojant sudarytą miesto funkcinès ir kompozicinès struktūrų sąveikos tyrimo modelį, buvo nustatyti dèl miesto plano neužbaigtumo ir (arba) neefektyvumo kylantys struktūrų prieštaringumai. Šiame skyriuje ìvertinamos dèl minètų prieštaringumų kylančių esamų lokalių centrų problemų sprendimo galimybès ir atskleidžiami būdai, padedantys išvengti šių problemų igyvendinant naujų lokalių centrų urbanistinius projektus. Pateikiama tyrimų duomenų interpretacija ir apibendrinimai gali būti pritaikyti sprendžiant kompozicinių ašių išdèstymo uždavini, kurị igyvendinus jos tampa tarpusavyje sujungtomis funkcinemis ašimis, užtikrinančiomis urbanistinès struktūros elementu funkcinị ir erdvinị sąryši, jungiamumą ir susisiekiamumą (galimybes susisiekti) bei socialinę interakciją (galimybes bendrauti). Trečiajame skyriuje pateikiamos išvados ir rekomendacijos buvo publikuotos straipsnyje mokslo žurnale „Journal of Architecture and Urbanism“ (Bučys 2013). 


\subsection{Lokaliụ centrų tyrimo ir gautų rezultatų santykis su kitų tyrèjų rezultatais}

Šio mokslinio darbo įvade išryškinti probleminiai urbanistinio projektavimo ir planavimo aspektai - atskirų miesto struktūros elementų nagrinejjimas ir jų tarpusavio ryšių ieškojimas arba siekimas sujungti geriausius pavienių elementų komponavimo sprendimus. Tai galima iliustruoti sovietinių metu statybos Lietuvos didmiesčių gyvenamuju rajonų pavyzdžiu. Nors ir suvokiama, kad funkcijų atskyrimas, vyraujanti gyvenamoji funkcija bei esamų pastatu išsidestymas turi neigiamos įtakos gyvybingoms viešosioms erdvėms, tačiau vengiama priimti sprendimus, leisiančius pertvarkyti esamą užstatymo struktūrą ir užtikrinti funkcijų ịvairovę. Klaidingas ir nepriimtinas požiūris yra siūlyti taikyti išskirtinius (o ne bendrai priimtinus), šiuo metu nesvarbius, planinès ekonomikos sąlygomis suplanuotiems gyvenamiesiems rajonams būdingus urbanistinès struktūros pertvarkymo būdus ir pletros principus (pavyzdžiui, siekiant užbaigti tai, kas buvo suplanuota, bet neigyvendinta, prisitaikant prie esamų statybos linijų, derinantis prie neproporcingai didelių kvartalų, nuo gatvès atitrauktų pastatų išsidèstymo ir darant kitas išimtis).

Esamų ar suplanuotu funkcijų išsidèstymo ir urbanistinès kompozicijos prieštaringumų arba neatitikimų, kylančių dèl miesto plano neužbaigtumo ir (arba) neefektyvumo kai kuriais atvejais nę̇manoma išvengti, pavyzdžiui, jeigu rengiant urbanistinius projektus ir juos igyvendinant yra ignoruojami urbanistinès struktūros formavimosi procesui būdingi dèsningumai, arba kitaip - viešujų erdvių tinklo intensifikacija, urbanistinès erdvès savybès, viešujų erdvių kokybė ir jų tarpusavio sąryšis. Reikia pažymèti, kad antrajame skyriuje dèmesys buvo sutelktas i minètoms savybèms didelę itaką turinčias priemones, t. y. i savo aiškiu suformavimu išsiskiriančiu vizualiai atskiru urbanistinès erdvès dalių, lokalių centrų vietas mieste žyminčių dominančių matomumo bei pastatų vidaus erdvių ir urbanistinès erdvès tarpusavio ryšio užtikrinimą. Tai ypač aktualu formuojant lokalius centrus, priimant sprendimus dèl gatvių tinklo struktūros, kai numatomos naujos jungtys turi ịtakos esamų gatvių galimybėms būti kelionių tikslu arba kelioniu iš vienos vietos i kitą vietą mieste dalimi.

Prieštaringumus arba neatitikimus lemiantys veiksniai taip pat yra susiję su dominuojančių užstatymo ir gatvių tinklo struktūros elementu vieta ir vaidmeniu lokaliu ir globaliu lygmeniu. Pavyzdžiui, vienas iš veiksmingos, efektyvios urbanistinès struktūros užtikrinimą apribojančių veiksnių - aukštybinių pastatų statyba atsitiktinèse vietose, neturint greta esančiu kvartalų plètros galimybes nustatančios koncepcijos. Kita problema - vietų aukštybiniams pastatams parinkimas, neatsižvelgiant i jų matomumą iš svarbiausių lokalius centrus sudarančių viešujų erdvių. Dominuojantys gatvių tinklo struktūros elementai išsiskiria aukštais pasiekiamumo rodikliais ir užtikrina miesto dalių jungiamumą, 
tačiau, kalbant apie detalius sprendimus, intensyvus automobilių judejimas ir didelis važiavimo greitis (didesnis kaip $50 \mathrm{~km} / \mathrm{h}$ ) gali būti kliūtis siekiant užtikrinti tinkamas sąlygas pėstiesiems, taigi ir socialinę interakciją (galimybes bendrauti). Pagrindinių gatvių arba jas sudarančių vizualiai atskirų urbanistinès erdvès dalių, tarp jų tiesiausių ir ilgiausių gatvių, kurios yra užmiesčio kelių tęsiniai (pavyzdžiui, Ukmergès gatvè Vilniuje), meninio ir vizualinio potencialo išnaudojimo apribojimus lemiantiems veiksniams priskiriamas automobiliu transportui pritaikytų infrastruktūros sprendimų vyravimas, pagrindinių ièjimų $j$ pastatus nebuvimas arba dirbtinis jų atitraukimas nuo gatvès (taip pat pagrindinių fasadų nukreipimas į šonines gatves).

Siekiant geriau suprasti veiksmingos, efektyvios urbanistinès struktūros užtikrinimą apribojančius veiksnius, siūlomo lokalių centrų funkcinès ir kompozicinės struktūrų elementų išsidèstymo, tarpusavio ryšių ir tarpusavio priklausomybès tyrimo modelio (3.1 pav.) panaudojimas leidžia atskleisti suplanuotoms (ypač taikant modernistinio (laisvojo) planavimo principus) miestų dalims būdingus trūkumus ir juos palyginti su kitų tyrèjų rezultatais.

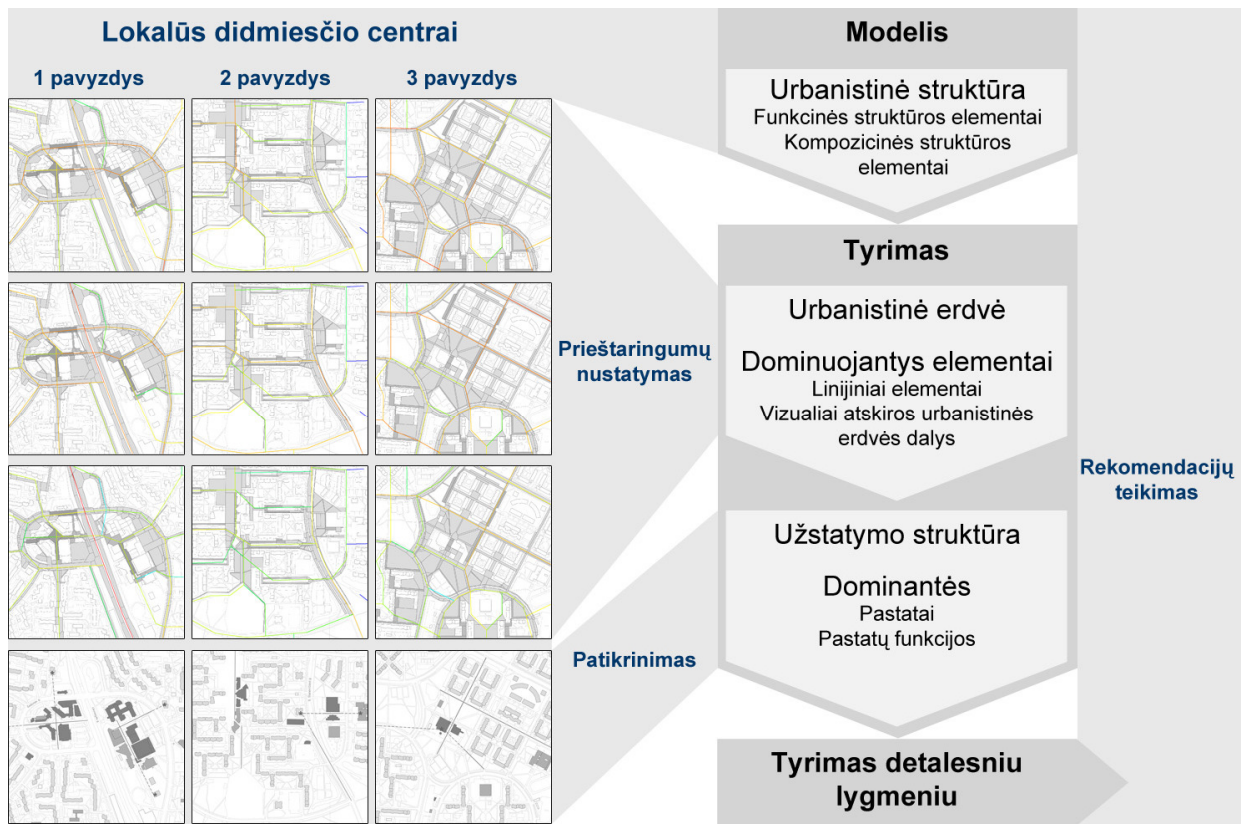

3.1 pav. Miesto funkcinès ir kompozicinès struktūrų sąveikos tyrimo modelis

Fig. 3.1. Model for investigating the interdependence of functional and compositional structures of the city 
Naujaisiais miestais vadinamų urbanistinių projektų, XX a. antroje pusejje igyvendintų Jungtinèje Karalystèje, prieštaringumų tyrimas (Karimi et al. 2009) yra aktualus pagrindžiant šiame moksliniame darbe pateikiamus apibendrinimus. Igyvendinant naujujų miestų ir jų dalių projektus suformuotos erdvès savybių ir socialinių bei ekonominių procesų mieste sąveika atskleista taikant matematinio ir grafinio modeliavimo priemones.

Svarbi pastarujų metu studija, kuri turejo didelès itakos space syntax metodikai plètoti - Londono lokalių centrų urbanistinès erdvès savybių ir socialinių bei ekonominių procesu mieste sąveikos tyrimas (Hillier 2009) atvèrè naujas sudètingu urbanistinès erdvès formavimo uždavinių sprendimo galimybes. Tyrimo rezultatai parodè, kad lokalių centrų urbanistinès erdvès konfigūracija turi tokių savybių, kurios išskiria nagrinètus centrus iš jų urbanistinio konteksto (Chiaradia et al. 2009b). Nors tyrimo rezultatai yra preliminarūs bei nepatvirtinti nagrinèjant daugiau miestų, tai gali būti naujos teorijos ir metodikos pagrindas. Atskleistos space syntax metodikos panaudojimo galimybès leidžia plètoti tvarumo sampratą ir îvertinti savaiminio formavimosi proceso veikiamų lokalių centrų svarbą ir įtaką darniai plètrai (Hillier 2009).

Palyginti su Londono lokalių centrų tyrimu, taikant šiame moksliniame darbe pristatomą urbanistinès kompozicijos vaidmens lokaliu ir globaliu lygmeniu nustatymo būdą, galima patikrinti, ar išnaudojamas lokalius centrus sudarančių viešujų erdvių meninis ir vizualinis potencialas, ir siūlyti iš esmès gerai žinomus $^{50}$, atitinkančius bendrai priimtinus plettros principus ir tradicijas ${ }^{51}$, tačiau urbanistinio projektavimo praktinejje veikloje dažnai ignoruojamus lokalių centrų problemų sprendimo būdus. Remiantis šiuo požiūriu galima teigti, kad atskleidžiant lokalių ir globalių urbanistinès erdvès savybių sutapimo įtaką centru formavimosi procesui, urbanistinès kompozicijos vaidmens ịvertinimas padeda geriau suprasti del miesto plano neužbaigtumo ir (arba) neefektyvumo kylančius prieštaringumus.

Kito tyrimo, kuris yra aktualus dèl pasirinkto tyrimo objekto, vienas iš uždavinių buvo palyginti Rio de Žaneiro miesto dalis, kurios yra savitos dèl skirtingų užstatymo morfologinių tipų (Netto et al. 2012). Preliminarūs rezultatai parodè nevienodą užstatymo struktūros elementų išsidèstymo ir jų ryšio su gatvès erdve vaidmenį ir patvirtino pavienių, remiantis modernistinio (laisvojo) planavimo principais nuo gatvès atitrauktų pastatų neigiamą ịtaką gyvybingoms viešosioms erdvėms, siekiant pėsčiųu judėjimui tinkamų sąlygų ir mažinant

\footnotetext{
${ }^{50}$ 1.3.1 skyrelyje paminèti K. Lyncho, G. Culleno, J. Jacobs ir C. Alexanderio darbai, vadinamosios tradicinès urbanistinio projektavimo teorijos (Marshall 2012).

${ }^{51}$ Bendrai priimtini, arba kitaip - bendri visiems žmonèms (commonly / widely accepted), nustatyti vadovaujantis objektyviais principais, dèl kurių tikrumo retai kam kyla abejonių arba trūksta mokslinių tyrimų, kad juos galima būtų ginčyti.
} 
poreikį naudotis lengvaisiais automobiliais. Minèto tyrimo rezultatai taip pat parodè, kad tradicinis sprendimas kvartalų ir juos jungiančių viešujų erdvių lygmeniu, suformuojant ištisinį užstatymą, nors ir nèra išimtinè viešujų erdvių gyvybingumą užtikrinanti sąlyga, tačiau yra glaudžiai susijęs su viešujų erdvių gyvybingumui svarbiomis architektūrinèmis erdvę ribojančių pastatų savybėmis. Pavyzdžiui, su prekybos ir paslaugų objektų išsidèstymu prie gatvès, mišriu pastatų naudojimu, langų ir durų angų vyravimu bei aklinų sienų ir kitų neperregimų elementų nebuvimu i gatvès erdvę nukreiptų pastatų fasadų plokštumose, arti viena kitos išsidèsčiusių patalpu pirmuosiuose pastatu aukštuose ir jose vykdomos veiklos įvairove, t. y. vienfunkcių stambių objektų nebuvimu.

\subsection{Lokaliụ centrụ urbanistinès struktūros formavimo principu nustatymas}

Remiantis gautais rezultatais, galima išskirti du lokalių centrų urbanistinès struktūros formavimo principus, kuriems pagrissti naudojami tyrimų metu gauti duomenys. Šiame poskyryje pateikiamomis rekomendacijomis siekiama parodyti šių svarbių principu igyvendinimo privalumus. Naudojant sudarytą miesto funkcinės ir kompozicinès struktūrų sąveikos tyrimo modeli praktinejje veikloje, pavyzdžiui, rengiant urbanistinius projektus, galima ịvertinti, ar esamų miesto dalių perplanavimas ir nauja plètra atitinka esamos struktūros galimybes ir užtikrina efektyvų urbanistinès struktūros funkcionavimą.

Pirmas svarbus principas - užtikrinti urbanistinès struktūros elementų jungiamumą globaliu ir lokaliu lygmeniu, t. y. numatyti lokalių centrų ryši su pagrindiniais judejjimo keliais (maršrutais) viso miesto mastu ir jungtis su gretimais kvartalais. Esant galimybei kiekvieną lokalų didmiesčio centrą kirsti pasirenkant lengvai suprantamus maršrutus, globaliu lygmeniu susiformuoja tarpusavyje sujungtų lokalių centrų tinklas, lokaliu lygmeniu sprendžiama kasdienius gyventojų poreikius tenkinančių prekybos ir paslaugų įmonių, darbo ir mokymo įstaigų bei laisvalaikio leidimo vietu pasiekiamumo problema.

Lokaliu lygmeniu yra aktualu svarstyti gatvių tinklo intensifikacijos ir sankryžų rekonstrukcijos galimybes. Pavyzdys, iliustruojantis užstatymo struktūros ir viešujų erdvių tinklo pletojimo sprendimų glaudų ryši yra susijęs su nagrinejjamais lokaliais centrais. Abipus Ukmergès gatvès išsidèsčiusio Šeškinès lokalaus centro dalis galima pasiekti naudojantis viena iš dviejų jungčiu - požemine perejja arba dviejų lygių Šeškinès ir Ukmergès gatvių sankryža. Fabijoniškių lokalaus centro trūkumas - skersinių gatvių, jungiančių Fabijoniškių ir S. Stanevičiaus gatves, nebuvimas. Lokalaus centro prieigose nutrūkstantys aklagatviai, t. y. nepakankamas įvairioms transporto priemonèms 
pritaikytų maršrutų pasirinkimas, turi įtakos viešujų erdvių gyvybingumui. Pèstiesiems paliktos dvi minèto lokalaus centro kirtimo galimybès: viena iš ju naudotis koridoriu primenančiu praejjimu, kita - pereiti per ūkinius kiemus. Susisiekimo sąlygų - didesnio kelių (maršrutų) pasirinkimo, pėsčiomis, viešuoju transportu ir automobiliais atvykstantiems lankytojams pritaikytos infrastruktūros kokybès gerinimas minètais atvejais yra svarbus veiksnys, siekiant užtikrinti lokalių centrų gyvybingumą ir galimybes plètotis. Panaikinant kai kuriuos tik pėstiesiems skirtus praejimus ir tankinant gatvių tinklą, pritaikytą susisiekti pėsčiomis bei naudotis įvairių rūšių transportu, visada reikia atsižvelgti i galimybes suformuoti užbaigtas ir ryškių ypatybių turinčias viešąsias erdves. Vis dèlto sovietiniais metais suformuotų lokalių centrų gatvių tinklo intensifikacija paremti sprendimai daugiausia privalumų teiktų automobiliais atvykstantiems lankytojams. Tai lemia viešujų ir privačių erdvių susipynimas, kuris savaime sudaro sąlygas pėsčiomis keliaujantiems žmonèms eiti trumpiausiu keliu ir kirsti rajonų viduje esančius kvartalus pasirenkant įvairius maršrutus (pavyzdžiui, einant per privačius gyventojų ir prekybos įmonių ūkinius kiemus). Kita vertus, igyvendinant ị lokalų centrą vedančių gatvių, skirtų sulètintam eismui (iki $20 \mathrm{~km} / \mathrm{h}$ ), sprendimus, jų važiuojamaja dalimi galètų naudotis dviratininkai, taip pat būtų sprendžiamas gyvybingumo ir pèsčiujuc saugumo užtikrinimo klausimas. Minèta priemonè gali iš dalies sumažinti lengvuju automobilių naudojimą, ypač keliaujant pésčiomis nedidelius atstumus (400-800 m), taip pat keliaujant dviračiais $2 \mathrm{~km}$ ir didesnius atstumus. Susidarius aplinkybėms, kai automobilių transporto judejjimas nèra intensyvus, kurti išskirtinai pėstiesiems skirtų zonų lokaliuose centruose nerekomenduojama.

Antras principas - stiprinti urbanistinès kompozicijos vaidmeni lokaliu ir globaliu lygmeniu. Gauti rezultatai rodo, kad sprendimai, priimti teikiant pirmenybę funkciniams klausimams spręsti, pavyzdžiui, pertvarkant esamas ir planuojant naujas gatves atskirti automobilių ir pėsčiųų srautus, ignoruojant gatvès erdvę kaip susitikimų ir bendravimo vietą, nesudarant tinkamų sąlygų socialinei interakcijai, gali būti miesto plano neužbaigtumo, kai neefektyviai išnaudojamas meninis ir vizualinis potencialas, priežastis, apribojanti gyvybingų viešųjų erdvių formavimosi galimybes. Nors remiantis šiame moksliniame darbe nagrinètais pavyzdžiais tai pagrịsti yra sudètinga, galima įvardyti šiuos tolesniems tyrimams svarbius pastebejjimus: pirmos kategorijos urbanistine kompozicija neturi didelių trūkumų, todèl nedideli pokyčiai (pavyzdžiui, dèl sprendimų, susijusių su erdvę ribojančių pastatų architektūra) neturi didesnès reikšmès (t. y. iš esmès nepaveikia viešosios erdvès - susitikimų ir bendravimo vietos - galimybių); antra kategorija įvardijama kaip neutrali (viešosios erdvès galimybių praradimo grèsmè gali kilti tik dèl didelių neigiamų pokyčių); trečios kategorijos urbanistinei kompozicijai tobulinti būtina ieškoti sprendimų (t. y. 
esminiai pokyčiai yra neišvengiami), tačiau ir nedideli pokyčiai gali būti santykinai svarbūs. Jeigu daugiau kaip 50 procentų visų lokalų centrą sudarančių viešujų erdvių yra priskirtos trečiai kategorijai, siekiant formuoti veiksmingą, efektyvią urbanistinę struktūrą, lokalių centrų gyvybingumui ir galimybėms plètotis gali turèti itakos tik esminiai pokyčiai, pradedant geriausiai pasiekiamų lokalaus centro daliu pertvarkymu.

Igyvendinant antrą principą remiamasi urbanistinès kompozicijos ịvertinimų ir viešujų erdvių pasiekiamumo verčių palyginimu: nustatoma, ar išnaudojamas lokalų centrą sudarančių vizualiai atskirų urbanistinès erdvès dalių meninis ir vizualinis potencialas. Remiantis tyrimų duomenimis, galima nustatyti vietas, kurių urbanistinès kompozicijos įvertinimai yra žemi, tačiau esant aukštesniems už vidutinius viešųju erdvių pasiekiamumo rodikliams galimi viešųjų erdvių kokybinių savybių pasikeitimai. Tokios probleminès vietos gali būti ir svarbiausioje lokalaus centro viešojoje erdvejje, ir centro pakraščio, ir už centro ribų esančiose viešosiose erdvèse. Siūlomos gyvybingų viešujų erdvių kūrimo ir plètojimo priemonès, ịvardytos 2.2.4 skyrelyje, yra pastatų architektūros tobulinimas ir viešujų erdvių kokybès gerinimas.

Atsižvelgiant ị nagrinėjamų lokalių centrų ypatumus, yra tikslinga svarstyti ištisinio užstatymo naujais pastatais, kurių pirmuosiuose aukštuose būtų vykdoma aktyvi veikla, viršutiniuose vyrautu gyvenamoji funkcija, galimybes. Ši rekomendacija nebūtų taikoma formuojant centro pakraščio ir už centro ribų esančius kvartalus, sudarytus iš paprastų, niekuo neišsiskiriančių užstatymo struktūros elementų. Žinoma, siekis suformuoti užbaigtas lokalius centrus sudarančias viešąsias erdves yra visiškai priešingas sovietiniais metais vyravusiam ir šiuo metu vis dar išplitusiam supratimui, kai pirmenybè teikiama modernistinio (laisvojo) planavimo principais paremtam erdvių formavimui, atskirai išdèstant nuo pagrindiniu gatviu atitrauktus gyvenamosios ir komercinès paskirties pastatus. Prie gatvès išsidèsčiusių ,aktyvių“ fasadų privalumus galima lengviau atskleisti pristatant kai kuriuos šiame moksliniame darbe nagrinejjamuose lokaliuose centruose pasiteisinusius sprendimus. Iš darančių didžiausią įtaką Šeškinès gatvejje po 1990 metų igyvendinti laisvų sklypų užstatymo naujais pastatais pavyzdžiai: prieš tai galèjusi būti priskirta tik trečiai kategorijai, viena iš minètos gatvès atkarpu šiuo metu įvardijama kaip pirmos, aukščiausios, kategorijos užbaigtos kompozicijos viešoji erdvė (3.2 pav.). Kitu gatvės atkarpų galimybès tapti aukščiausios kategorijos priklauso nuo neefektyviai naudojamų sklypų užstatymo ir architektūrinių sprendimų, įtraukiant naujų pastatų fasadų nukreipimą i gatvès erdvę.

Vertinant nagrinejjamus lokalius centrus sudarančių viešujų erdvių urbanistinès kompozicijos reikšmingumą, didžiausią poveikį daro Šeškinès lokalų centrą supančios ir iš pagrindinių kompozicinių mazgų gerai matomos dominantès - gyvenamosios paskirties aukštybiniai pastatai. Priešingai, S. Stanevičiaus 
gatvejje Fabijoniškèse esantys aukštybiniai pastatai ir Pašilaičių lokalaus centro urbanistinio komplekso pastatas turi įtakos tik kai kurių viešujų erdvių urbanistinès kompozicijos įvertinimams.

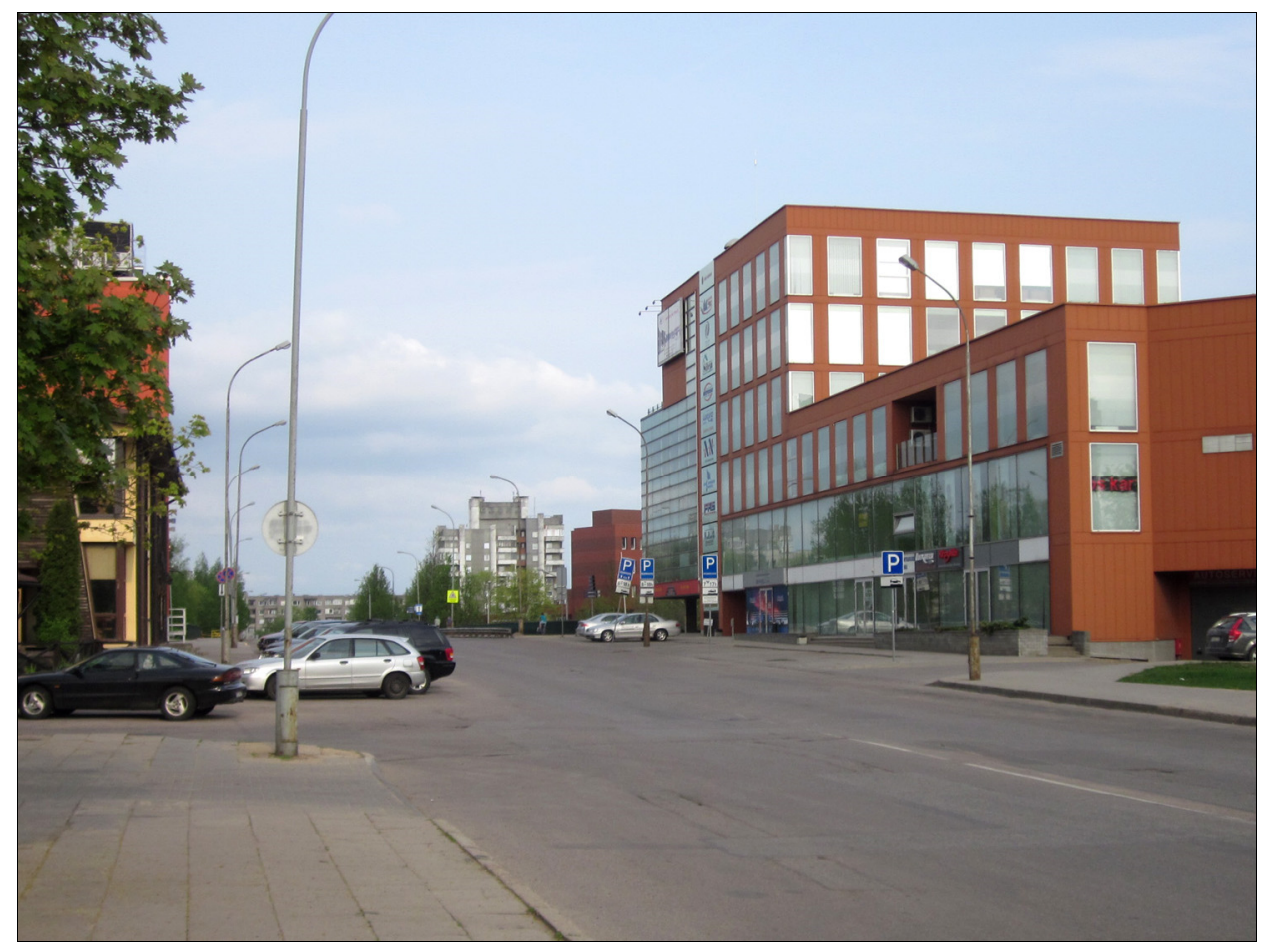

3.2 pav. Šeškinès gatvès atkarpa, užbaigtos kompozicijos viešosios erdvės pavyzdys Fig. 3.2. Segment of Šeškinès Street, an example of a public space of complete composition

Reikia pripažinti, kad bet koks esamos struktūros pertvarkymas ir (arba) naujas užstatymas turi ịtakos gretimų kvartalų plètrai. Todèl ịvardyti principai yra glaudžiai tarpusavyje susiję. Šiame skyrelyje išskirtiems lokalių centrų urbanistinès struktūros formavimo principams (urbanistinès struktūros elementų jungiamumo užtikrinimo ir urbanistinès kompozicijos vaidmens lokaliu ir globaliu lygmeniu stiprinimo) bei vadinamosiose tradicinèse urbanistinio projektavimo teorijose minimoms priemonèms (susisiekimui pésčiomis palankaus kvartalų dydžio parinkimo ir kliūčių pésčiųuu judejjimui tinkamoms sąlygoms susidaryti pašalinimo, pakankamo gyventojų skaičiaus (tankio) užtikrinimo) derinti, t. y. teorinèms nuostatoms ir praktinèms rekomendacijoms sujungti, turi 
būti skiriamas didžiausias pavieniu mokslininkų ar jų grupių dėmesys. Gauti rezultatai naudojami nustatant urbanistinès struktūros formavimo principus, lengvai pritaikomus urbanistinio projektavimo praktinejje veikloje, leidžiančius išnaudoti esamos struktūros galimybes ir siekti efektyvaus urbanistinès struktūros funkcionavimo, vieno iš svarbiausių darnios plètros prioritetų.

\subsection{Bendrai priimtini plètros principai ir sprendimų prièmimas}

Siekiant šiame poskyryje pateiktų gyvybingų viešujų erdvių formavimo rekomendacijų atitikimo bendrai priimtiniems pletros principams, ju gyvybingumo ir suplanuotų funkcijų išsidèstymo mieste bei vietų naujiems traukos objektams ivertinimo ryšys gali būti patikrintas ir atskleistas sujungiant funkcinius ir kompozicinius urbanistinès struktūros analizès aspektus - apskaičiuojant viešujų erdviu pasiekiamumo vertes bei nustant meninį ir vizualinį urbanistinès erdvès potencialą.

Kalbant apie tarpusavyje susijusių sprendimų visumą (nuo detaliojo iki strateginio lygmens), lokalių centrų vizualiai atskirų urbanistinès erdvès dalių urbanistinès kompozicijos įvertinimas ir kategorijų nustatymas leidžia geriau suprasti nagrinejamą miesto dali kaip visumą ir priimti strateginius sprendimus dèl urbanistinès kompozicijos vaidmens stiprinimo. Tai taip pat leidžia numatyti galimus viešŭjų erdvių kokybinių savybių pasikeitimus. Detalių sprendimų, sutelktų i viešujų erdvių gyvybingumui svarbias architektūrines erdvę ribojančių pastatų savybes, tikslingumas priklauso nuo vizualiai atskirų urbanistinès erdvės dalių, išsiskiriančių savo aiškiu suformavimu, lokalių centrų vietas mieste žyminčių dominančių matomumu bei užtikrintu pastatų vidaus erdvių ir urbanistinès erdvès tarpusavio ryšiu ${ }^{52}$.

Atskleidžiant šiame moksliniame darbe pristatomo modelio praktinio panaudojimo galimybes, svarbus privalumas, palyginti su šiuo metu taikomais metodais, yra susijęs su traukos objektų išdèstymu, jų vaidmens nustatymu ir itvirtinimu rengiant urbanistinius projektus. Nustačius vietas lokaliems centrams plètotis, neišvengiamai iškyla efektyvaus esamų pastatų ir jų užimamų sklypų išnaudojimo, pakankamo užstatymo tankio užtikrinimo ir, ypač svarbu, griežto viešųjų ir privačių erdvių atskyrimo poreikis. Tokie sprendimai priimami rengiant esamų užstatymo struktūros elementų tobulinimo ir prie gatvių esančių

\footnotetext{
${ }^{52}$ Pastatų vidaus erdvių ir urbanistinės erdvès tarpusavio ryšys priklauso nuo pastatu fasadų plokštumų ir architektūrinių savybių (užstatymo struktūros elementų atvirumo arba „permatomumo" principo ịgyvendinimo). Matomumą ribojančiomis vizualinėmis kliūtimis gali būti ịvardyti pastatų fasadus užstojantys objektai viešosiose erdvėse.
} 
neaiškios paskirties plotų užstatymo projektinius siūlymus. Todèl, siekiant perplanuoti aktyvia veikla išsiskiriančias sovietiniais metais suformuotu gyvenamujų rajonų dalis, yra tikslinga susitelkti i 3.2 poskyryje nustatytus naujų užstatymo struktūros elementų įterpimo ir lokalius centrus sudarančių viešujų erdvių formavimo prioritetus.

Miestų savivaldos institucijoms neskubant apibrèžti sovietinių metų statybos gyvenamujų rajonų, ypač suplanuotų centrų, plètros strateginių gairių ir jų urbanistinès struktūros formavimo principų (tai svarbu, siekiant išvengti fragmentiško atskirų kvartalu perplanavimo), reikia kelti klausimą, ar visi nagrinètuose lokaliuose centruose pastaruoju metu igyvendinti naujų pastatų ir juos supančių viešujų erdvių projektai gali būti ịvardijami kaip reikšmingai pagerinantys esamą būklę. Nuo to, kiek dèmesio bus skirta Šššinès, Fabijoniškių ir Pašilaičių lokalių centrų stiprinimui ir jų vaidmens pokyčius lemsiantiems naujiems iššūkiams, pavyzdžiui, Šiaurinès gatvès tiesimui ir Ukmergès gatvès pertvarkymui iš greito eismo gatvès ị skirtingiems susisiekimo būdams pritaikytą prekybinę gatvę, atsižvelgiant ì keliamą lokalių centrų jungiamumo problemą ir gretimų kvartalų užstatymo struktūros formavimo galimybes, priklausys ne tik efektyviai funkcionuojančios viešųų erdvių tinklo struktūros užtikrinimas, bet ir gyvenimo kokybè, bendruomenių sanglaudos stiprejimas, ir kiti socialiniai bei ekonominiai procesai. Nors šiame moksliniame darbe paminèti ne visi socialiniai bei ekonominiai aspektai ir būtina patikrinti bei pagrissti jų sąryšị, tačiau remiantis tyrimų metu gautais duomenimis ir kitų tyrejų rezultatais galima teigti, kad veiksmingas, efektyvus miesto planas yra vienas iš svarbiausių susisiekimo ir bendravimo galimybes užtikrinančių veiksnių.

Sudarytas miesto funkcinès ir kompozicinès struktūrų sąveikos tyrimo modelis atspindi menini ir vizualini potencialą bei socialinius ir ekonominius procesus mieste. Su urbanistinès erdvès konfigūracijos bei žmonių judejjimo mieste pokyčiais tiesiogiai susijęs kompozicinių ašių ir mazgų išdėstymas turi būti tikrinamas naudojant gatvių ir kitų viešujų erdvių tinklo modelius ir jais paremtus analizès metodus. Šio svarbaus urbanistinio projektavimo etapo sprendimai priimami remiantis intuicija ir meniniais principais ${ }^{53}$. Problema yra ta, kad rengiant miestų ar jų daliu projektus vien tik intuicija paremti metodai negali užtikrinti palankių rezultatu. K. Karimio (2012a) straipsnyje pateikti būdai, kaip urbanistinio projektavimo procese taikomi analizès metodai gali daryti teigiamą poveiki kuriant projekto koncepciją ir padèti priimti tinkamus sprendimus vèlesniame projekto plètojimo etape. Remiantis K. Karimio sudarytu

${ }^{53}$ Apskritai, projektavimo procesas negali būti paremtas vien moksliniais argumentais, bet suvokiamas kaip intuicijos ir loginio mąstymo sąveika, todèl proceso dalyviams siūloma susitelkti ị projekto idejų kūrimą ir jų patikrinimą, taikant pasirinktus kriterijus (Karimi 2012a; Darke 1984). 
urbanistinio projektavimo proceso modeliu (3.3 pav.), kuriame svarbus vaidmuo tenka urbanistinès struktūros ivertinimui taikant space syntax metodiką, galima ivardyti urbanistinès kompozicijos ir jos vizualinio suvokimo analizès vietą minètame procese. Šiame moksliniame darbe taikoma metodika yra ir pirminio esamos būklès tyrimo, ir kuriamo projekto ịvertinimo dalis.

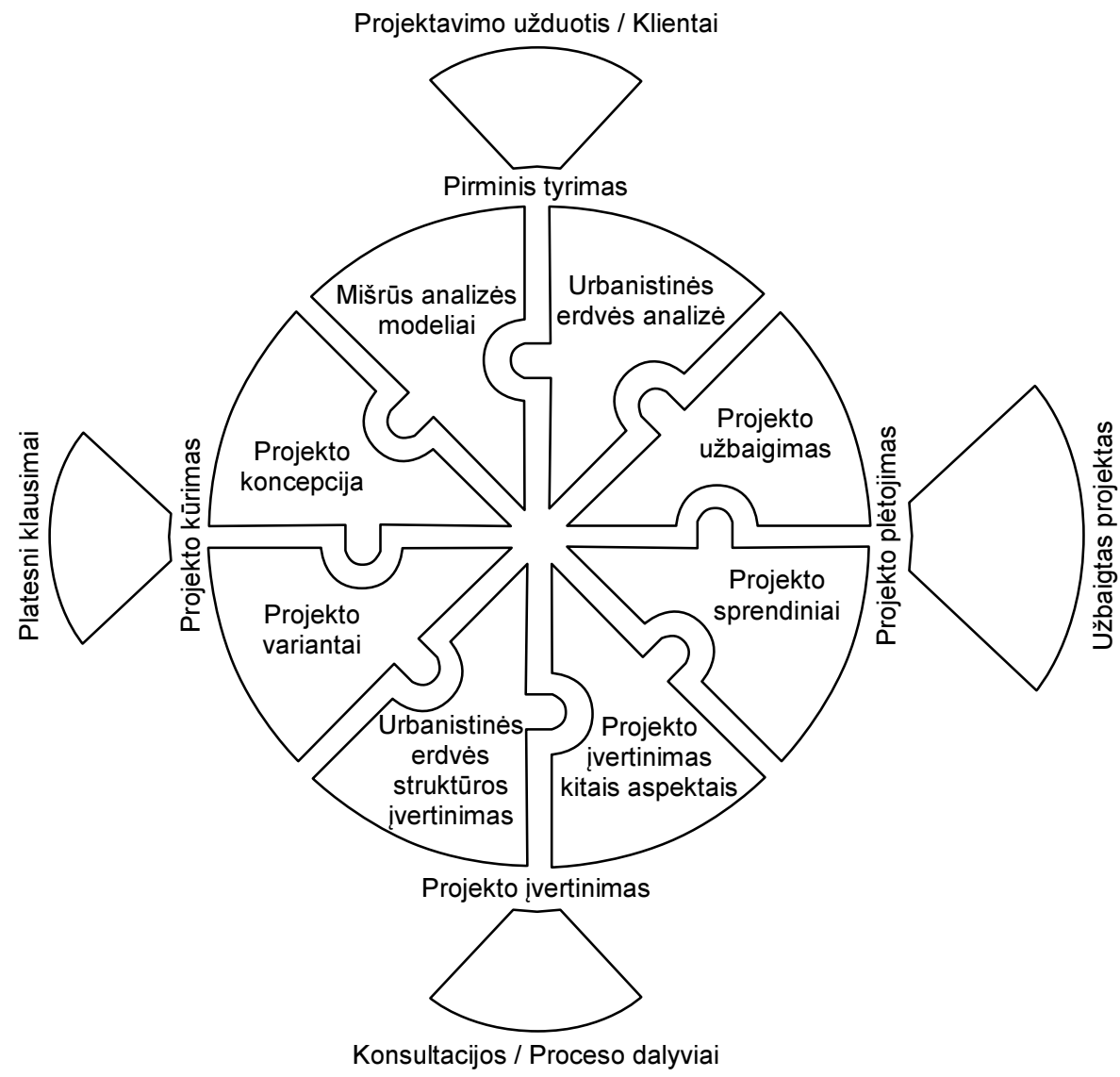

3.3 pav. Space syntax metodikos naudojimo urbanistinio projektavimo procese modelis (Karimi 2012a: 309)

Fig. 3.3. Configurational approach to analytical urban design: space syntax methodology (Karimi 2012a: 309) 
Urbanistinio projektavimo proceso dalyvių kūrybinès raiškos laisvè turi ribas, nes paprastai remiamasi sprendimais, atitinkančiais bendrai priimtinus plètros principus ir tradicijas, vadinamają „erdvès socialinę logiką" (t. y. lokalių centrų urbanistinès struktūros formavimas, kaip procesas, turi savo natūralią vietą ir ribas). Todèl ir architekto veikla šioje srityje negali būti visiškai laisva, t. y. jis turi žinoti neriboto naudojimosi savo veiksmų laisve pasekmes. Bet koks dirbtinis plètros sulaikymas arba, atvirkščiai, neproporcingas sutelkimas ar savaiminis išsiplètojimas ${ }^{54}$ sukeltu priešingą veikimą (pavyzdžiui, nepagrịstai sulaikytai arba, priešingai, neribotai plètrai nepritariantys bendruomenių atstovai naudotųsi teise ginti viešaji interesą) arba ateityje pareikalautų atoveiksmio strategijos. Šią išvadą galima paremti JK Vyriausybès planavimo politikos gairèse pateikiama nuostata, kad ,planavimo sistema neturi veikti taip, kad būtu ribojama konkurencija, išsaugoma esamų komercinių interesų itaka ir užkertamas kelias inovacijoms“" (PPS6... 2005: 6). Inovacijų skatinimą ir pastangas išlaikyti esamą padètį skirianti pavojinga riba gali būti peržengta, kai dèl esamų trukdymų ir draudimų apribojamos bet kokių pokyčių galimybès. Ir, priešingai, nepamatuoti pertvarkymai, kai tikimasi greitos naudos, paprastai turi ilgalaikių padarinių. Jei neatsakingai keičiama tai, kas ịprasta ir gerai veikia, $\mathfrak{i}$ tai, kas dar neišbandyta ir prieštarauja susiklosčiusioms tradicijoms, tokios naujovès gali sunkiai prigyti esamoje socialineje ir ekonomineje aplinkoje. Natūraliam apribojimui gali būti priskiriamas priešingas veikimas, kai nesudaromos sąlygos igyvendinti visuomenei nepriimtiną urbanistini projektą (vienas iš svarbių apribojimų yra bendruomenių priešinimasis, atsisakymas duoti sutikimą tęsti viešaji interesą pažeidžiančio projekto igyvendinimą). Taigi bet koks savaiminès plètros reguliavimas yra veiksmingas, kai yra aiškiai suvokiami mieste vykstantys socialiniai, ekonominiai ir kultūriniai procesai bei atsižvelgiama i urbanistinès struktūros formavimosi procesui būdingus dèsningumus.

Vienas iš nagrinèjamoje miesto dalyje įgyvendintų nesèkmingų urbanistinių projektų - prekybos paviljonų komplekso prie Fabijoniškių ir S. Stanevičiaus gatviu sankryžos įrengimas. Suplanuotas traukos objektas, siekiant dirbtinai sutelkti prekybos ir paslaugu įmones smulkiajam verslui nepatrauklioje vietoje, neatsižvelgus i gatvių tinklo ypatumus, natūraliai nesiplètojo. Kita komplekso neefektyvaus funkcionavimo priežastis - vienodu atstumu nuo minètos vietos i skirtingas puses nutolę šiuo metu savaime besiplečiantys Fabijoniškių ir Šeškinès lokalūs centrai. Priešingai nei minèto komplekso, greta viešojo transporto stotelių (prie S. Stanevičiaus gatvès ir ì suplanuotą Fabijoniškių lokalų centrą vedančio aklagatvio sankryžos) esantys prekybos ir paslaugų paviljonai išsiskiria

${ }^{54}$ Čia turimas omenyje ir nuo žmonių judèjimo priklausančių funkcijų išsklidimas arba jų sutelkimas netinkamose vietose, ir nesuderintas su ,erdvès socialine logika“ kompozicinės struktūros elementų išsidèstymas. 
aktyvia veikla. Šis pavyzdys parodo, kad svarbu numatyti tinkamas vietas aktyvios veiklos židiniams, kurie padeda viešajai erdvei tapti gyvybingai ir intensyviai naudojamai.

Istoriniai miestai vystėsi veikiami savaiminio formavimosi proceso, neturint išankstinių planų ar kitų gatvių tinklo struktūros plètrą suvaržančių apribojimų (išskyrus, žinoma, gynybines sienas bei natūralias kliūtis). Pagrindiniai žmonių judejjimo keliai lemdavo traukos objektų vietos pasirinkimą, atitinkamai aktyvios veiklos telkiniai turèdavo ịtakos žmonių srautų padidejjimui, ir tokio padidejjimo pasekmè - naujų traukos objektų ir besiformuojančio gatvių tinklo elementų atsiradimas $^{55}$. Śiuo metu naujujų miesto daliu kompozicinè struktūra formuojama rengiant urbanistinius projektus - išdèstomos kompozicinès ašys, nustatomos kvartalų ribos bei atskirų pastatų vieta ir vaidmuo. Tačiau suprojektuotų kvartalų ir juos jungiančių viešųjų erdvių kaip visumos funkcionavimo efektyvumas paprastai nèra vertinamas, apsiribojant suplanuotų funkcijų išdėstymu, arba vertinamas pavėluotai. Gyvybingos viešosios erdvės susiformuoja (arba nesusiformuoja) jau igyvendinus urbanistinius projektus. Nors gatvių ir kitu viešujų erdvių tinklo modeliai, kuriuos tikslinga taikyti projektuojant naująsias miestų dalis, kvartalus ir juos jungiančias viešąsias erdves, jau yra išplètoti ir toliau tobulinami, jais paremti analizès metodai urbanistinio projektavimo praktineje veikloje iki šiol taikyti dar palyginti retai ${ }^{56}$.

Užduodant klausimą, ar viešujų erdvių tinklo galimybių atskleidimas siekiant palengvinti strateginių sprendimų dèl pletros krypčių prièmimą yra pakankama sąlyga, kad būtų užtikrintas miesto raidos tęstinumas, vienareikšmio atsakymo negali būti. Mieste yra nuolat priimami sprendimai (fizinių ir juridinių asmenų ar savivaldybès lygmens) dèl esamų kvartalu pertvarkymo ir plètros, naujų traukos objektų vietų parinkimo ir funkcijų sutelkimo ar atskyrimo. Priimtų sprendimų rezultatas - nauji užstatymo struktūros elementai, susieti su juos supančiomis viešosiomis erdvėmis ir turintys didelès įtakos gatvių tinklo naudojimo efektyvumui. Todèl visuomet išlieka grèsmè, kad remiantis fragmentiškais duomenimis ar šališka ir klaidinančia informacija bei neįvertinus viešuju erdvių galimybių (potencialo) ilgam gali būti ịtvirtinama tokia padètis, kai dèl esamų ir suplanuotų funkcijų išsidèstymo ir urbanistinès kompozicijos priešta-

\footnotetext{
${ }^{55}$ Billas Hillier (1999) tokiai naujų traukos objektų atsiradimo ir žmonių srautụ padidejjimo tarpusavio priklausomybei apibūdinti vartojo didinamojo (multiplikatoriaus) efekto (multiplier effect) terminą.

${ }^{56}$ Space syntax metodikos taikymo urbanistinio projektavimo praktinejje veikloje problema, nagrinejjant urbanistinius sprendimus ir teikiant rekomendacijas dèl jų tobulinimo, yra nuolat keliama metodiką plètojančių mokslininkų straipsniuose (Hanson 1989; Hillier 1993; Hanson 2012; Karimi 2012a; 2012b).
} 
ringumų kylantys apribojimai nustelbia gaunamą ekonomini efektą ${ }^{57}$. Priešingai, toks veikimas, kai igyvendinus urbanistinio projektavimo sprendimus neapribojamos natūralaus judejimo ir aktyvios veiklos židinių susitelkimo galimybès, yra pagrịstas poreikiu naudotis viešujų erdvių tinklo teikiamais privalumais ir, esant būtinybei, keisti tam tikrus elementus ir plètoti tinklą taip, kad geriausiai atsiskleistu meninis ir vizualinis potencialas ir nebūtų sudarytos kliūtys ateities kartoms esamą struktūrą pritaikyti naujiems poreikiams tenkinti. Tai yra svarbi sąlyga, keliama miestams, siekiantiems igauti ir padidinti pranašumą, turèti galimybes rinktis ir prisitaikyti prie nuolatiniu pokyčiu (augimo ir nykimo), susijusių su gatvių tinklo intensifikacija ar esamos padèties išlaikymu bei aktyvios veiklos židinių išsiplètimu ar susitraukimu.

Svarbu, kad savivaldos institucijų strateginiai sprendimai tvirtinant miestų plètros planus ir svarstant kitus planavimo klausimus būtų aiškūs ir atitiktų bendrai priimtinus plètros principus, o jų igyvendinimas skaidrus ir nešališkas. Didelę reikšmę tam turi sudarytos palankios sąlygos bendruomenèms dalyvauti priimant sprendimus. Siekiant iškelto tikslo - stiprinti lokalius centrus, gerinant ju pasiekiamumą pėsčiomis ir viešuoju transportu, mažinant priverstines keliones lengvuoju automobiliu - savivaldos institucijos turi galimybes inicijuoti savaiminius procesus bei, numatytose vietose atsiradus aktyvios veiklos židiniams, skatinti natūralią plètrą, t. y. socialinius ir ekonominius procesus, paremtus veiklos laisve ir iniciatyva. Tai ypač svarbu pertvarkant neproporcingai didelius kvartalus vidurinèse miestų dalyse, planuojant pastatų funkcijų pokyčiams atsparius gatvių tinklo struktūros elementus ir parenkant kvartalų dydị.

Dèl gautų rezultatų panaudojimo tolesniems tyrimams, reikia pripažinti, kad šiame moksliniame darbe pateiktas modelis apima ne visus architekto kūrybinès raiškos būdus, siekiant urbanistinès aplinkos kokybès, nukreiptus ị miesto, jo dalies ar kvartalų grupès ir gyvybingų viešujų erdvių formavimą, įtraukiant urbanistinès kompozicijos bendram vertinimui svarbų vertikalių ir horizontaliu dominančių, kurios, remiantis istorinių miestų pavyzdžiais, yra universalūs lokalių centrų vietas mieste žymintys orientyrai, vaidmens stiprinimą. Nors miesto plano struktūros, dominančių, kompozicinių ašių, mazgų ir kitų elementų vietos ir vaidmens klausimai paprastai sprendžiami įvertinus mieste vykstančius socialinius ir ekonominius procesus ${ }^{58}$, vis dèlto gauti rezultatai yra aktualūs kasdienejje architekto veikloje ịgyvendinant urbanistinès kompozicijos užbaigtumo ir būdin-

\footnotetext{
${ }^{57}$ Pavyzdžiui, sutelkiant dėmesị tik ị projekto igyvendinimo kainą ir pasirenkant pigiausią alternatyvą, gali būti apribojamos galimybès plètotis. Priešingai, investuojant ị urbanistinio projekto kokybę ir skiriant daugiau dèmesio vertès kūrimui, siekiama gauti ilgalaikès naudos (Chiaradia et al. 2009a).

${ }^{58}$ Šiame moksliniame darbe pristatomas urbanistinès kompozicijos vaidmens lokaliu ir globaliu lygmeniu nustatymo būdas gali būti plètojamas ir taikomas rengiant aukštybinių pastatų išdèstymo planus.
} 
gumo principus, t. y. ieškant sprendimų, padedančių užtikrinti gatvèvaizdžio ir miesto plano aiškumą bei pastatų vidaus erdvių ir urbanistinès erdvès tarpusavio ryšį. Svarbu, kad architektai siektų pasinaudoti pateikiamų pavyzdžių analizės rezultatais, juos kūrybiškai interpretuoti ir, ịvertinus konkretaus urbanistinio projekto ypatumus, taikyti įvardytus veiksmingos, efektyvios urbanistinès struktūros formavimo principus savo praktinejje veikloje.

Šis mokslinis darbas remiasi būdingų Vilniaus miesto pavyzdžių - probleminèmis ịvardijamų miesto dalių - nagrinèjimu, todèl ịvertinus tyrimų objekto pasirinkimo apribojimus ir išnagrinèjus preliminarius kitų tyrējų rezultatus išryškejjusias modelio plètojimo galimybes būtų tikslinga nustatytus lokalių centrų urbanistinès struktūros formavimo principus palyginti su kitų sovietiniais metais suformuotų Lietuvos didmiesčių dalių tyrimų duomenimis, taip pat išplèsti kompozicinių urbanistinès struktūros analizès aspektų pasirinkimą. Sukurtas modelis ir gauti rezultatai suteikia galimybę tęsti tyrimus, ịtraukiant papildomas subjektyvaus vertinimo metu nustatomas urbanistinès kompozicijos savybes, pavyzdžiui, prasmingumą, išraiškingumą, kontrastingumą, atraktyvumą ir kt.

\subsection{Trečiojo skyriaus išvados}

1. Atskleidžiant lokalių ir globalių urbanistinès erdvès savybių sutapimo itaką centrų formavimosi procesui, urbanistinès kompozicijos vaidmens ivertinimas padeda geriau suprasti dèl miesto plano neužbaigtumo ir (arba) neefektyvumo kylančius prieštaringumus. Taikant šiame moksliniame darbe pristatomą urbanistinès kompozicijos vaidmens lokaliu ir globaliu lygmeniu nustatymo būdą, galima patikrinti, ar išnaudojamas lokalius centrus sudarančių viešujų erdvių meninis ir vizualinis potencialas, ir siūlyti iš esmès gerai žinomus, atitinkančius bendrai priimtinus plètros principus ir tradicijas, tačiau urbanistinio projektavimo praktinejje veikloje dažnai ignoruojamus lokalių centrų problemų sprendimo būdus.

2. Remiantis gautais rezultatais, galima išskirti du lokalių centrų urbanistinès struktūros formavimo principus: urbanistinès struktūros elementų jungiamumo užtikrinimą ir urbanistinès kompozicijos vaidmens lokaliu ir globaliu lygmeniu stiprinimą. Igyvendinant pirmą principą turi būti išnaudojamos gatvių tinklo intensifikacijos ir sankryžų rekonstrukcijos galimybès. Susisiekimo sąlygų - didesnio kelių (maršrutų) pasirinkimo, pėsčiomis, viešuoju transportu ir automobiliais atvykstantiems lankytojams pritaikytos infrastruktūros kokybès gerinimas yra svarbus veiksnys, siekiant užtikrinti lokalių centrų gyvybingumą ir galimybes plètotis. Igyvendinant antrą principą remiamasi urbanistinès kompozicijos įvertinimų ir viešujų erdvių pasiekiamumo verčių palyginimu. Nustačius, kad 
lokalų centrą sudarančių vizualiai atskirų urbanistinès erdvės dalių meninis ir vizualinis potencialas nèra tinkamai išnaudojamas, galima siūlyti gyvybingų viešujų erdvių kūrimo ir plètojimo priemones.

3. Urbanistinio projektavimo proceso dalyvių kūrybinès raiškos laisvè turi ribas, nes paprastai remiamasi sprendimais, atitinkančiais bendrai priimtinus plètros principus ir tradicijas, vadinamają ,erdvès socialinę logiką“. Todèl ir architekto veikla šioje srityje negali būti visiškai laisva. Bet koks dirbtinis plètros sulaikymas arba, atvirkščiai, neproporcingas sutelkimas ar savaiminis išsiplètojimas sukeltų priešingą veikimą arba ateityje pareikalautu atoveiksmio strategijos. 


\section{Bendrosios išvados}

1. Remiantis sudarytu miesto funkcinès ir kompozicinès struktūrų sąveikos tyrimo modeliu, integruojančiu matematinio ir grafinio modeliavimo priemones ir urbanistinès kompozicijos įvertinimo metodą, vienu metu nagrinèti keletas tarpusavyje susijusių funkciniu ir kompozicinių miesto plètros aspektų. Globaliu lygmeniu nustatyti Vilniaus urbanistinès struktūros ypatumai, glaudžiai susiję su ịvairių lygmenų centrų bei subcentrų išsidėstymu mieste. Lokaliu lygmeniu sudarytas modelis naudotas kaip suplanuotų funkcijų ir esamos struktūros galimybių ryšio arba neatitikimo tyrimo objektyvus pagrindas.

2. Sudarytas miesto funkcinès ir kompozicinès struktūrų sąveikos tyrimo modelis atspindi meninị ir vizualinị potencialą bei socialinius ir ekonominius procesus mieste. Su urbanistinès erdvès konfigūracijos bei žmonių judejjimo mieste pokyčiais tiesiogiai susijęs kompozicinių ašių ir mazgų išdèstymas turi būti tikrinamas naudojant gatvių ir kitų viešujų erdvių tinklo modelius ir jais paremtus analizès metodus. Tam siūloma sujungti tikslių kiekybinių tyrimo metodu galimybes: naudotis specializuotomis kompiuterių programomis matematinių skaičiavimų, skirtų nustatyti viešujų erdvių pasiekiamumo vertes, užduotims atlikti ir vykdyti natūrinius tyrimus, kurių metu lankantis vietoje ịvertinamas urbanistinę erdvę formuojančių pastatų vaidmuo. 
3. Apibendrinus gautus Vilniaus miesto šiaurès vakarų dalyje esančių trijų lokalių centru tyrimo rezultatus nustatyta, kad urbanistinès kompozicijos ivertinimas remiantis trimis pagrindiniais - užbaigtumo, reikšmingumo ir būdingumo - kriterijais padeda palyginti tam tikro lokalaus centro vizualiai atskiras urbanistinès erdvès dalis ir atskleisti greta esančių lokalių centrų meninio ir vizualinio potencialo skirtumus. Aukštesni ịvertinimai reiškia efektyviai išnaudojamas viešujų erdvių plètojimo galimybes. Žemiausi ịvertinimai rodo poreikị atsižvelgti ị viešųų erdvių pasiekiamumo rodiklius ir ieškoti urbanistinès kompozicijos, įtraukiant dominančių, kompozicinių ašių ir mazgų išdèstymą, tobulinimo sprendimų.

4. Lokalių ir globalių urbanistinès erdvès savybių santykị ir urbanistinę kompoziciją siūloma vertinti siekiant suprasti nagrinèjamą miesto dalị kaip visumą ir priimti strateginius sprendimus dèl urbanistinès kompozicijos vaidmens stiprinimo. Nustatytos nagrinejjamų lokalių centrų vizualiai atskirų urbanistinès erdvès dalių kategorijos ir ju palyginimas su apskaičiuotomis pasiekiamumo vertèmis leidžia atskleisti urbanistinès erdvès formavimo galimybes ir numatyti galimus esamų viešujų erdvių kokybinių savybių pasikeitimus.

5. Urbanistinès struktūros elementu jungiamumo užtikrinimas ir urbanistinès kompozicijos vaidmens lokaliu ir globaliu lygmeniu stiprinimas yra būtinos priemonès, kurios sudaro sąlygas išnaudoti esamos struktūros galimybes ir siekti efektyvaus urbanistinès struktūros funkcionavimo, vieno iš svarbiausių darnios plètros prioritetų. Siūlomos Vilniaus miesto Šeškinès, Fabijoniškių ir Pašilaičių lokalių centrų viešųjų erdvių tinklo struktūros pertvarkymo priemonės yra patogių jungčių su aplinkinių gatvių tinklu įrengimas, esamų sankryžų rekonstrukcija ir naujų gatvių, kuriose būtų teikiama pirmenybè sulètintam eismui, gyvenamujų rajonų viduje tiesimas. Neefektyviai naudojamų sklypų užstatymas, naujų pastatų fasadus nukreipiant į gatvès erdvę, ir esamų pastatų architektūros tobulinimas, taikant pastatų vidaus erdvių ir urbanistinès erdvès tarpusavio ryšį užtikrinančius sprendimus, leidžia suformuoti užbaigtas ir ryškių ypatybių turinčias viešąsias erdves. 


\section{Literatūra ir šaltiniai}

Alexander, C. 1965. A city is not a tree, Architectural Forum [interaktyvus] 122(1): 5862 (1 dalis) ir 122(2): 58-62 (2 dalis) [žiūreta 201205 10]. Prieiga per internetą: http://www.rudi.net/books/200.

Alexander, C.; Ishikawa, S.; Silverstein, M.; Jacobson, M.; Fiksdahl-King, I.; Angel, S. 1977. A Pattern Language. New York: Oxford University Press. 1171 p.

Alistratovaitè, I. 2004. Morfologinès struktūros transformacijos centriniame miesto rajone (Lietuvos pavyzdžiu): daktaro disertacija: humanitariniai mokslai, menotyra 03H, skulptūra ir architektūra - H312. Vilnius. 242 p.

Alistratovaitè, I. 2008. Uostamiesčio vizualinio ivaizdžio formavimo galimybès ir problemos: aukštybinių pastatų specialiojo plano rengimas - esama situacija ir koncepcija, Urbanistika ir architektüra 32(2): 71-85.

Alistratovaitè, I. 2009. Uostamiesčio vizualinio ịvaizdžio plètros galimybès ir problemos: aukštybinių pastatų išdèstymo specialiojo plano rengimas - sprendinių konkretizavimas ir pasekmių vertinimas, Urbanistika ir architektūra 33(2): 49-81.

Al-Sayed, K. 2012. A systematic approach towards creative urban design, iš (Proceedings) Design Computing and Cognition DCC'12 [interaktyvus], red. John S. Gero. Berlin, Heidelberg: Springer Science+Business Media, 1-20 [žiūreta 201304 30]. Prieiga per internetą: http://mason.gmu.edu/ jgero/conferences/dcc12/DCC12Digital Proceedings/Digital\%20pdf/Al_Sayed-2.pdf. 
Al-Sayed, K.; Turner, A.; Hanna, S. 2012. Generative structures in cities, iš Proceedings of the 8th International Space Syntax Symposium [elektroninis išteklius], 3rd to 6th January 2012 [CD]. Santiago de Chile: Pontificia Universidad Católica de Chile, 1-18. Prieiga per internetą: http://www.sss8.cl/media/upload/paginas/seccion/8070_2.pdf.

Bacon, E. 1967. The Design of Cities. New York: Viking Press. 296 p.

Batty, M. 2004. A New Theory of Space Syntax [interaktyvus]. London: Centre for Advanced Spatial Analysis, University College London. 36 p. [žiūrèta 201003 26]. Prieiga per internetą: http://www.casa.ucl.ac.uk/working_papers/paper75.pdf.

Batty, M. 2009. Notes on accessibility, iš Proceedings of the 7th International Space Syntax Symposium [interaktyvus]. Stockholm: KTH, 1-4 [žiūrèta 201206 07]. Prieiga per internetą: http://www.sss7.org/Proceedings/02\%20Invited\%20Papers/I02_Batty_ Notes_on_Accessibility.pdf.

By Design: Urban Design in the Planning System - Towards Better Practice [interaktyvus]. 2000. London: Department of the Environment, Transport and the Regions, Commission for Architecture and the Built Environment. 99 p. [žiūrèta 201206 07]. Prieiga per internetą: http://www.communities.gov.uk/documents/planningandbuilding/ pdf/158490.pdf.

Bratuškins, U. 2006. Riga Old Town Public Open Space Development in the 20th and 21 st Centuries. Doctorate Thesis Summary. Riga: RTU. 51 p.

Buivydas, R.; Samalavičius, A. 2011. Public spaces in Lithuanian cities: legacy of dependence and recent tendencies, Urban Studies Research [interaktyvus] 2011: 1-9 [žiūrèta 201207 01]. Prieiga per internetą: http://www.hindawi.com/journals/usr/2011/ 284573.

Carmona, M. 2001. The Value of Urban Design: A Research Project Commissioned by CABE and DETR to Examine the Value Added by Good Urban Design [interaktyvus]. London: Thomas Telford. 112 p. [žiūrèta 2013 04 04]. Prieiga per internetą: http://www.designcouncil.org.uk/Documents/Documents/Publications/CABE/the-valueof-urban-design.pdf.

Carmona, M.; Heath, T.; Oc, T.; Tiesdell, S. 2003. Public Places - Urban Spaces: The Dimensions of Urban Design. Oxford: Architectural Press. 320 p.

Chiaradia, A.; Hillier, B.; Barnes, Y.; Schwander, C. 2009a. Residential property value patterns in London. Space syntax spatial analysis, iš Proceedings of the 7th International Space Syntax Symposium [interaktyvus]. Stockholm: KTH, 1-12 [žiūrèta 201206 07]. Prieiga per internetą: http://www.sss7.org/Proceedings/07\%20Urban\%20Structures\%20 and\%20Spatial\%20Distribution/015_Chiaradia_Hillier_Barnes_Schwander.pdf.

Chiaradia, A.; Hillier, B.; Schwander, C.; Wedderburn, M. 2009b. Spatial centrality, economic vitality/viability. Compositional and spatial effects in Greater London, iš Proceedings of the 7th International Space Syntax Symposium [interaktyvus]. Stockholm: KTH, 1-19 [žiūrèta 201206 07]. Prieiga per internetą: http://www.sss7.org/ Proceedings/07\%20Urban\%20Structures\%20and\%20Spatial\%20Distribution/016_Chiar adia_Hillier_Schwander_Wedderburn.pdf. 
Christaller, W. 1933. Die zentralen Orte in Süddeutschland. Jena: Gustav Fischer. 331 p.

Claramunt, C.; Winter, S. 2007. Structural salience of elements of the city, Environment and Planning B: Planning and Design [interaktyvus] 34(6): 1030-1050 [žiūrèta 201304 19]. Prieiga per internetą: http://www.envplan.com/epb/fulltext/b34/b32099.pdf.

Conroy Dalton, R.; Bafna, S. 2003. The Syntactical Image of the City: A Reciprocal Definition of Spatial Elements and Spatial Syntaxes, iš Proceedings of the 4th International Space Syntax Symposium [interaktyvus]. London, 1-22 [žiūrèta 201206 07]. Prieiga per internetą: http://eprints.ucl.ac.uk/1104/1/SIC.pdf.pdf.

Cowan, R. 2005. The Dictionary of Urbanism. Tisbury: Streetwise Press. 468 p.

Cullen, G. 1961. Townscape. New York: Reinhold Pub. Corp. 315 p.

Dabartinès lietuviu kalbos žodynas: šeštas (trečias elektroninis) leidimas. 2011. Redaktorių kolegija: Stasys Keinys (vyr. redaktorius), Laimutis Bilkis, Jonas Paulauskas, Vytautas Vitkauskas. Vilnius: Lietuvių kalbos institutas [žiūrèta 201205 02]. Prieiga per internetą: http://dz.lki.lt.

Darke, J. 1984. The primary generator and the design process, iš Developments in Design Methodology, red. Nigel Cross. New York: John Wiley \& Sons, 175-188.

Daunora, Z. J.; Kirvaitienè, S.; Vyšniūnas, A. 2004. Vilniaus vizualinio identiteto apsauga ir plètros principai. Vilnius: Technika. $152 \mathrm{p}$.

Daunora, Z. J. 1995. Naujos Vilniaus plètros gairès, Urbanistika ir architektūra 1920(1-2): 4-27.

Daunora, Z. J. 1989. Vilniaus centro erdvinio plètojimo kryptys, iš Vilniaus miesto centro urbanistinès plètojimo problemos ir ju sprendimo büdai: konferencijos, vykusios Vilniuje 1989 m. kovo 17-18 d., tezès. Vilnius, 14-18.

Dringelis, L. 2005. Miesto viešosios erdvès: pokyčių tendencijos ir savitumo išsaugojimas, Urbanistika ir architektūra 29(1): 50-54.

Freeman, L. C. 1977. A set of measures of centrality based on betweenness, Sociometry 40: 35-41.

Frey, H. 1999. Designing the City: Towards a More Sustainable Urban Form. London: E \& FN Spon. 148 p.

Gehl, J. 1987. Life Between Buildings - Using Public Space. New York: Van Nostrand Reinhold. 202 p.

Glaeser, E. 2011. Triumph of the City: How Our Greatest Invention Makes Us Richer, Smarter, Greener, Healthier, and Happier. New York: The Penguin Press. 352 p.

Grunskis, T. 2002. Sociokultūrinio konteksto ịtaka miesto visuomeninių erdviu formavimui: daktaro disertacija: humanitariniai mokslai, menotyra $-03 \mathrm{H}$, skulptūra ir architektūra - H312. Vilnius. 178 p.

Gumauskaitè, V. 2000. Struktūralizmo apmatai: sq̨vokos, metodas, filosofija. Vilnius: Lietuvos filosofijos ir sociologijos institutas. 204 p. 
Hall, P. 1998. Cities and Civilization: Culture, Innovation, and Urban Order. London: Weidenfeld \& Nicholson. 1170 p.

Hanson, J. 1989. Order and structure in urban design: the plans for the rebuilding of London after the Great Fire of 1666, Ekistics 56 (334-335): 22-42.

Hanson, J. 2012. Foreword: 'Order and structure in urban design: the plans for the rebuilding of London after the Great Fire of 1666', The Journal of Space Syntax 3(1): 35-37 [žiūrėta 201206 07]. Prieiga per internetą: http://joss.bartlett.ucl.ac.uk/journal/ index.php/joss/article/view/125/pdf.

Harary, F. 1969. Graph Theory. Reading, Massachusetts: Addison-Wesley. 274 p.

Hillier, B. 1989. The architecture of the urban object, Ekistics 56(334-335): 5-21. Prieiga per internetą: http://discovery.ucl.ac.uk/82/1/hillier-1989-ArchUrbObject.pdf.

Hillier, B. 1993. Specifically architecture theory: a partial account of the ascent from building as cultural transmission to architecture as theoretical concretion, Harvard Architecture Review [interaktyvus] 9: 8-27 [žiūrèta 201205 13]. Prieiga per internetą: http://eprints.ucl.ac.uk/1027/1/hillier_1993-specifically_architectural.pdf.

Hillier, B. 1996. Cities as movement economies, Urban Design International [interaktyvus] 1(1): 41-60 [žiūrèta 201206 07]. Prieiga per internetą: http://discovery.ucl.ac.uk/ 1403/1/hillier-96-citiesmovementeconomies.pdf.

Hillier, B. 1999. Centrality as a process: accounting for attraction inequalities in deformed grids, Urban Design International [interaktyvus] 4(3): 107-127 [žiūrèta 2010 03 26]. Prieiga per internetą: http://www.spacesyntax.com/Files/MediaFiles/ Hillier_1999.pdf.

Hillier, B. 2007. Space is the Machine [interaktyvus]. 1996 metais pirmą kartą išleistos monografijos elektroninis variantas. London: Space Syntax. 355 p. [žiūrèta 201003 26]. Prieiga per internetą: http://www.spacesyntax.com/tool-links/downloads/space-is-themachine.aspx.

Hillier, B. 2009. Spatial sustainability in cities, iš Proceedings of the 7th International Space Syntax Symposium [interaktyvus]. Stockholm: KTH, 1-20 [žiūrèta 201206 07]. Prieiga per internetą: http://www.sss7.org/Proceedings/01\%20Key-note\%20Papers/ K01_Hillier_Spatial_Sustainability.pdf.

Hillier, B.; Burdett, R.; Peponis, J.; Penn, A. 1987. Creating life: or, does architecture determine anything? Architecture and Behaviour [interaktyvus] 3(3): 233-250 [žiūrèta 201303 06]. Prieiga per internetą: http://discovery.ucl.ac.uk/101/1/hillier-etal-1987creating-life.pdf.

Hillier, B.; Hanson, J. 1984. The Social Logic of Space. Cambridge: Cambridge University Press. 281 p.

Hillier, B.; Iida, S. 2005. Network and psychological effects in urban movement, iš Spatial Information Theory, red. Anthony G. Cohn ir David M. Mark. Lecture Notes in Computer Science 3693. Berlin, Heidelberg: Springer-Verlag, 475-490. 
Hillier, B.; Yang, T.; Turner, A. 2012. Normalising least angle choice in Depthmap and how it opens up new perspectives on the global and local analysis of city space, The Journal of Space Syntax [interaktyvus] 3(2): 155-193 [žiūrèta 2013 03 06]. Prieiga per internetą: http://joss.bartlett.ucl.ac.uk/journal/index.php/joss/article/view/141/pdf.

Hillier, B.; Leaman, A.; Stansall, P.; Bedford, M. 1976. Space syntax, Environment and Planning B: Planning and Design [interaktyvus] 3(2): 147-185 [Žiūrèta 20120607 ]. Prieiga per internetą: http://discovery.ucl.ac.uk/1062/1/hillier-etal-1976_Space_ Syntax.pdf.

Hillier, B.; Penn, A.; Hanson, J.; Grajewski, T.; Xu, J. 1993. Natural movement: or configuration and attraction in urban pedestrian movement, Environment and Planning B: Planning and Design [interaktyvus] 20(1): 29-66 [žiūrèta 201003 26]. Prieiga per internetą: http://eprints.ucl.ac.uk/1398.

Jacobs, J. 1961. The Death and Life of Great American Cities. New York: Vintage Books. 458 p.

Jenks, M.; Burton, E.; Williams, K. (Eds.). 1996. The Compact City: A Sustainable Urban Form? London: Spon Press. 360 p.

Jurkštas, V. 1975. Kauno senamiesčio tūrinè-erdvinė kompozicija, Architektūros paminklai 3: 98-120.

Jurkštas, V. 1977. Vilniaus senamiesčio tūrinè-erdvinė kompozicija, Architektūros paminklai 4: 36-60.

Jurkštas, V. 1994. Senamiesčiu regeneracija: architektūros harmonizavimo problema. Vilnius: Technika. 160 p.

Juškevičius, P.; Jauneikaitè, K. 2008. Urbanistinių struktūrų formavimo ir žemės naudojimo klasifikavimo problematika, Urbanistika ir architektūra 32(4): 240-247.

Juškevičius, P.; Valeika, V. 2007. Lietuvos miestu sistemu raida. Vilnius: monografija. Vilnius. 240 p.

Karimi, K. 1998. Continuity and Change in Old Cities: An Analytical Investigation of the Spatial Structure in Iranian and English Historic Cities Before and After Modernisation. PhD Thesis. London: University College London. 402 p.

Karimi, K. 2000. Urban conservation and spatial transformation: preserving the fragments or maintaining the 'spatial spirit', Urban Design International [interaktyvus] 5(3-4): 221-231 [žiūrèta 201206 07]. Prieiga per internetą: http://www.palgravejournals.com/udi/journal/v5/n3/pdf/9000012a.pdf.

Karimi, K. 2012a. A configurational approach to analytical urban design: 'Space syntax' methodology, Urban Design International [interaktyvus] 17(4): 297-318 [žiūrèta 2012 11 09]. Prieiga per internetą: http://www.palgrave-journals.com/udi/journal/v17/n4/pdf/ udi201219a.pdf.

Karimi, K. 2012b. A reflection on 'Order and structure in urban design', The Journal of Space Syntax 3(1): 38-48 [žiūrèta 201206 07]. Prieiga per internetą: http://joss.bartlett .ucl.ac.uk/journal/index.php/joss/article/view/111/pdf. 
Karimi, K.; Rose, A.; Martinez, M.; Raford, N. 2009. New towns of England: understanding failure with Space Syntax, iš Model Town: Using Urban Simulation in New Town Planning, red. Egbert Stolk ir Marco te Brömmelstroet. Amsterdam: Uitgeverij SUN, 19-43.

Kauno miesto savivaldybès teritorijos bendrasis planas [interaktyvus]. 2003. SI „Kauno planas“ [žiūrèta 201206 07]. Prieiga per internetą: http://bendrasisplanas.kaunas.lt.

Kirvaitienè, S. 2007. Miesto ịvaizdžio formavimo galimybès ir uždaviniai plètojant centro aplinką: daktaro disertacija: humanitariniai mokslai, menotyra $-03 \mathrm{H}$, skulptūra ir architektūra - H312. Vilnius. 134 p.

Klaipédos miesto bendrasis planas [interaktyvus]. 2007. Klaipėdos miesto savivaldybė [žiūrèta 201206 07]. Prieiga per internetą: http://www.klaipeda.lt/go.php/lit/Miesto_ bendrasis_planas/366/3/317/1.

Klippel, A.; Winter, S. 2005. Structural salience of landmarks for route directions, iš Spatial Information Theory, red. Anthony G. Cohn ir David M. Mark. Lecture Notes in Computer Science 3693. Berlin, Heidelberg: Springer-Verlag, 347-362.

Krupickaitè, D.; Beconytė, G. 2011. Miesto funkciniu tyrimu sociogeografineje praktikoje metodiniai nurodymai [interaktyvus]. Vilnius: Vilniaus universitetas. 81 p. [žiūrèta 201203 15]. Prieiga per internetą: http://www.kc.gf.vu.lt/FT/.

Levin, P. H. 1984. Decision making in urban design, iš Developments in Design Methodology, red. Nigel Cross. New York: John Wiley \& Sons, 107-121.

Lietuvos urbanistikos paveldas: vertybiu įteisinimas, apsauga, tvarkymas (1967-1993). 2005. Dokumentų rinkinys. Sudarè Algimantas Miškinis. Vilnius: Savastis. 212 p.

Lynch, K. 1960. The Image of the City. Cambridge: The MIT Press. 194 p.

Madanipour, A. 1996. Design of Urban Space: An Inquiry into a Socio-Spatial Process. New York: John Wiley \& Sons. 241 p.

Marshall, S. 2004. Streets and Patterns: The Structure of Urban Geometry. London: Routledge. 336 p.

Marshall, S. 2012. Science, pseudo-science and urban design, Urban Design International [interaktyvus] 17(4): 257-271 [žiūrèta 201211 09]. Prieiga per internetą: http://www.palgrave-journals.com/udi/journal/v17/n4/pdf/udi201222a.pdf.

Miškinis, A. 1974. Lietuvos miestelių išplanavimo ir erdvinès struktūros charakteristika, iš Lietuvos TSR architektūros klausimai 4. Vilnius: Mintis, 103-166.

Miškinis, A. 1991. Lietuvos urbanistika: istorija, dabartis, ateitis. Vilnius: Mintis. 154 p.

Moughtin, C.; Cuesta, R.; Sarris, C.; Signoretta, P. 1999. Urban Design: Method and Techniques. Oxford: Architectural Press. 195 p.

National Planning Policy Framework [interaktyvus]. 2012. London: Department for Communities and Local Government. 65 p. [žiūrèta 201206 07]. Prieiga per internetą: http://www.communities.gov.uk/documents/planningandbuilding/pdf/2116950.pdf. 
Netto, V., et al. 2012. The convergence of patterns in the city: (isolating) the effects of architectural morphology on movement and activity, iš Proceedings of the 8th International Space Syntax Symposium [elektroninis išteklius], 3rd to 6th January 2012 [CD]. Santiago de Chile: Pontificia Universidad Católica de Chile, 1-32. Prieiga per internetą: http://www.sss8.cl/media/upload/paginas/seccion/8167_1.pdf.

Norberg-Schulz, Ch. 1980. Genius Loci: Towards a Phenomenology of Architecture. New York: Rizzoli. 216 p.

Ostwald, M. 2011. The mathematics of spatial configuration: revisiting, revising and critiquing justified plan graph theory, Nexus Network Journal [interaktyvus] 13(2): 445470 [žiūrèta 201206 07]. Prieiga per internetą: http://www.springerlink.com/content/ r4vk67m0m471021t/.

Penn, A.; Hillier, B.; Banister, D.; Xu, J. 1998. Configurational modelling of urban movement networks, Environment and Planning B: Planning and Design [interaktyvus] 25(1): 59-84 [žiūrèta 201206 07]. Prieiga per internetą: http://discovery.ucl.ac.uk/ 1400/1/penn-hillier-banister-xu-1998.pdf.

Perry, C. 1929. The neighborhood unit, iš Neighborhood and Community Planning, vol. 7, Regional Survey of New York and Its Environs. New York: Regional Plan of New York, 20-89.

Petrušonis, V. 2011. Kultūrinių archetipų recepcija planuojant urbanistinę renovaciją, Urbanistika ir architektūra 35(4): 260-266.

Petrušonis, V. 2002. Vietovès kultūrinio tapatumo subjektinis substratas, Urbanistika ir architektūra 26(1): 18-36.

Places, Streets \& Movement [interaktyvus]. 1998. A companion guide to Design Bulletin 32. Residential roads and footpaths. London: Office of the Deputy Prime Minister. 84 p. [žiūrèta 201206 07]. Prieiga per internetą: http://www.communities.gov.uk/documents/ planningandbuilding/pdf/151558.pdf.

Planning and Urban Design Standards. 2006. Hoboken: John Wiley \& Sons. 736 p.

Planning for Town Centres: Guidance on Design and Implementation tools [interaktyvus]. 2005. London: Office of the Deputy Prime Minister. 6 p. [žiūrèta 20120607 ]. Prieiga per internetą: http://www.communities.gov.uk/documents/planningandbuilding/ pdf/147594.pdf.

PPS6. 2005. Planning for Town Centres: Planning Policy Statement 6 [interaktyvus]. London: TSO. 34 p. [žiūrèta 200901 08]. Prieiga per internetą: http://www.communities.gov.uk/documents/planningandbuilding/pdf/147399.pdf.

Purvinas, M. 1975. Kraštovaizdžio erdvinès struktūros pirminiai vienetai ir jų galimos charakteristikos, Statyba ir architektūra 14(4): 5-21.

Purvinas, M. 1983. Subjektyvus kraštovaizdžio vertinimas, iš Lietuvos TSR architektūros klausimai 8. Vilnius: Mokslas, 60-69.

Rogers, R.; Power, A. 2000. Cities for a Small Country. London: Faber \& Faber. 314 p. 
Rossi, A. 1984. The Architecture of the City. Cambridge, Massachusetts: The MIT Press. $208 \mathrm{p}$.

Rowe, C.; Koetter, F. 1978. Collage City. Cambridge, Massachusetts: The MIT Press. $185 \mathrm{p}$.

Sabidussi, G. 1966. The centrality index of a graph, Psychometrika 31: 581-603.

Siksna, A. 1998. City centre blocks and their evolution: a comparative study of eight American and Australian CBDs, Journal of Urban Design [interaktyvus] 3(3): 253-283 [žiūrèta 201206 07]. Prieiga per internetą: http://www.tandfonline.com/doi/pdf/10.1080/ 13574809808724429.

Siksna, A. 1997. The effects of block size and form in North American and Australian city centres, Urban Morphology [interaktyvus] 1: 19-33 [žiūrèta 201206 07]. Prieiga per internetą: http://urbanmorphology.org/online_unlimited/um199701_19-33.pdf.

Siksna, A. 2006. The study of urban form in Australia, Urban Morphology [interaktyvus] 10(2): 89-100 [žiūrèta 201206 07]. Prieiga per internetą: http://www.urbanform.org/pdf/siksna2006.pdf.

Sitte, C. 1945. The Art of Building Cities - City Building According to Its Artistic Fundamentals. I anglų kalbą vertė Charles T. Stewart. Pirmą kartą išleista vokiečių kalba 1889 metais. New York: Reinhold Publishing Corporation. 128 p.

Stauskas, V. 2006. Miestų žaliosios erdvès socialinių ir ekonominių interesų balanso aspektu, Urbanistika ir architektūra 30(1): 15-18.

Stauskis, G.; Eckardt, F. 2011. Empowering public spaces as catalysers of social interactions in urban communities, Urbanistika ir architektūra 35(2): 117-128.

Šešelgis, K. 1975. Rajoninio planavimo ir urbanistikos pagrindai. Vilnius: Mintis. 336 p.

Šiaulių miesto bendrasis planas [interaktyvus]. 2008. UAB „Urbanistika“ [žiūrèta 2012 06 07]. Prieiga per internetą: http://www.siauliai.lt/architektura/bplanas.php.

Tarptautinių žodžių žodynas. 2013. Redaktorių taryba: Angelè Kaulakienė ir kt. Vilnius: Alma littera. 888 p.

Turner, A. 2007. From axial to road-centre lines: a new representation for space syntax and a new model of route choice for transport network analysis, Environment and Planning B: Planning and Design [interaktyvus] 34(3): 539-555 [žiūrèta 20100326 ]. Prieiga per internetą: http://eprints.ucl.ac.uk/2092.

Vanagas, J. 2003. Miesto teorija: vadovèlis. Vilnius: Vilniaus dailès akademijos leidykla. $248 \mathrm{p}$.

Vanagas, J. 2008. Urbanistikos pagrindai: vadovėlis. Vilnius: Technika. 244 p.

Van Nes, A. 2007. The spatial conditions for a vital compact city. The structure of the street net and its impact on urban sustainability, iš Urban Sustainability and Sustainable Mobility. Papers from the 8th Nordic Environmental Social Science Research Conference [interaktyvus]. Oslo: Norwegian Institute for Urban and Regional Research, 27-45 [žiūrèta 201206 07]. Prieiga per internetą: http://www.nibr.no/filer/2007-113.pdf. 
Van Nes, A.; Stolk, E. 2012. Degrees of sustainable location of railway stations: integrating space syntax and node place value model on railway stations in the province of North Holland's strategic plan for 2010-2040, iš Proceedings of the 8th International Space Syntax Symposium [elektroninis išteklius], 3rd to 6th January 2012 [CD]. Santiago de Chile: Pontificia Universidad Católica de Chile, 1-25. Prieiga per internetą: http://www.sss8.cl/media/upload/paginas/seccion/8005_1.pdf.

Venturi, R. 1966. Complexity and Contradiction in Architecture. New York: Museum of Modern Art. 132 p.

Vilniaus miesto bendrasis planas. 1999. Vilniaus miesto taryba, Miesto plètros departamentas, Savivaldybės įmonè „Vilniaus planas“. Vilnius: Briedis. 78 p.

Vilniaus miesto savivaldybès teritorijos bendrasis planas iki $2015 \mathrm{~m}$. [interaktyvus]. 2006. SI „Vilniaus planas“ [žiūrèta 201206 07]. Prieiga per internetą: http://www.vilnius.lt/index.php?3160752297.

Whyte, W. 1980. The Social Life of Small Urban Spaces. Washington, D. C.: The Conservation Foundation. 125 p. 



\section{Autoriaus mokslinių publikacijụ disertacijos tema sąrašas}

\section{Straipsniai recenzuojamuose mokslo žurnaluose}

Bučys, J. 2009. Daugiafunkcių didmiesčio centrų formavimo bendrieji uždaviniai [Common objectives of the formation of mixed-use city centres], Mokslas - Lietuvos ateitis: K. Šešelgio skaitymai - 2009 [Science - Future of Lithuania: K. Šešelgis Readings - 2009] 1(2): 17-21. ISSN 2029-2341. (ICONDA, Gale, ProQuest, EBSCOhost, IndexCopernicus).

Bučys, J. 2010. Lokalių centrų vieta ir vaidmuo hierarchinejje didmiesčio centrų sistemoje: Vilniaus pavyzdys [Location and role of local centres in the hierarchical system of city centres: case study of Vilnius city], Urbanistika ir architektūra [Town Planning and Architecture] 34(2): 98-105. ISSN 1392-1630. (SCOPUS, H. W. Wilson, ICONDA, CSA, Gale, ProQuest, EBSCOhost, IndexCopernicus).

Bučys, J. 2013. Funkcinių ir kompozicinių urbanistinès struktūros analizès aspektų sujungimas: Vilniaus miesto lokalių centrų tyrimas [Combining functional and compositional aspects of the analysis of urban structure: a case study of local centres in Vilnius], Journal of Architecture and Urbanism [Urbanistika ir architektūra] 37(2): 141159. ISSN 2029-7955. (SCOPUS, H. W. Wilson, ICONDA, CSA, Gale, ProQuest, EBSCOhost, IndexCopernicus). 


\section{Straipsniai kituose recenzuojamuose leidiniuose}

Bučys, J. 2008. Kai kurios miesto užstatymo struktūros formavimo problemos [Some issues on the formation of built-up structure of the city], iš K. Šešelgio skaitymai - 2008 [K. Šešelgis Readings - 2008]. Rokiškis, 2008 m. gegužès 8-9 d. Vilnius: Technika, 4857. ISBN 978-9955-28-266-2. Prieiga per internetą: http://www.vgtu.lt/upload/leid konf/bucys_48-57.pdf.

Bučys, J. 2012. Understanding coherence between functional and compositional structures of the city: a case study of local centres in Vilnius [Miesto funkcinès ir kompozicinès struktūrų sąryšio problema: Vilniaus lokalių centrų pavyzdys], iš Proceedings of the 8th International Space Syntax Symposium [elektroninis išteklius], 3rd to 6th January 2012 [CD]. Santiago de Chile: Pontificia Universidad Católica de Chile, 1-8. ISBN 978-956-345-862-6. Prieiga per internetą: http://www.sss8.cl/media/ upload/paginas/seccion/8050.pdf. 


\section{Summary in English}

\section{Introduction}

\section{Formulation of the Problem}

A considerable difficulty in defining priorities with respect to urban structure formation is the absence of appropriate strategic urban design and planning guidelines. Therefore, one of the purposes should be an explanation of functional and compositional aspects of urban structure formation, embracing their consistency. This is applied to Lithuanian cities, particularly in the places formed using the principles of strict separation of land uses and pedestrian/vehicle movement.

The problem addressed in this dissertation is a "separate" (i.e. "non-combined") approach to the functional and compositional aspects of the formation of urban structure. Functional issues are likely to dominate in both the analysis and design of the physical form of the city. As a critical question, this could be examined through research aimed at a better understanding of interdependence between functional and compositional structures.

The dissertation discusses the problem of coherence between functional and compositional structures of the city based on the existing and planned functions, including the possibilities of moving within the street network with a focus on urban composition and with regard to corresponding or non-corresponding relation. In order to achieve new scientific results, specifically defined research methods focusing on relevant cases have been chosen. 
A possibility of every location, including workplaces, educational institutions and recreation areas, in an urban grid to easily access a range of shops and local services that meet everyday needs seems to be one of the biggest advantages of living in the city. Combining tasks encouraging the growth of local centres and developing a street network in a way to promote walking and provide conditions for using different modes of transport is one of the most appropriate ways to achieve urban sustainability.

\section{Topicality of the Thesis}

Potential locations for concentration and a mix of land uses and activities are the places where the degree of the coincidence of local and global properties is as high as shown by Hillier (2009) in his case study on London local centres. An attempt to assess coherence between functional and compositional structures presented in this dissertation contributes to expanding knowledge of the features determining a spatially successful local centre. In particular, research findings can be significant for examining design solutions because of developed spatial analysis methods that were not available when conceptual schemes reminiscent of those used for designing large-scale housing estates (in the United Kingdom along with spread in other countries) were developed.

\section{Object of Research}

The study focuses on relevant cases of Vilnius city, districts and their centres that have a predominant residential land use. The object of research is the main features that determine coherence between functional and compositional structures in the local centres of the city.

\section{Aim of the Work}

The dissertation is aimed at developing a model for investigating interdependence between functional and compositional structures of the city and is based on the analysis of the existing local centres. The thesis explores the possibilities of its application for defining formation principles of an effective urban structure.

\section{Tasks of the Work}

The main tasks of the work are as follows:

1. To describe methods for analysing functional and compositional structures of the city which are critical in the context of a common understanding of urban design and priorities regarding public space formation.

2. To define common objectives established to form mixed-use city centres and briefly explore the development possibilities of local centres in Lithuanian cities.

3. To investigate the importance and role of key intrinsic spatial features on the formation of local centres and combine functional and compositional aspects of the analysis of urban structure.

4. To identify the main features determining coherence between functional and compositional structures and possibilities of their evaluation in order to define the principles of urban structure formation in the local centres of the city. 


\section{Methodology of Research}

Space syntax is a method for the analysis of spatial structure used in the fields of architecture, urban design and planning and based on the geometrical representation of the spatial pattern. It aims to reveal the effects of spatial layout on social and economic processes in a city. The main theoretical propositions based on a specific theory of movement economy are related to how people perceive, move through and use urban space (Hillier, Hanson 1984; Hillier 2007).

The methods employed in the dissertation correspond to the basic principles of compositional analysis and were laid down in papers by Jurkštas $(1975 ; 1977)$, and methodological recommendations based on investigation into the urban composition of Lithuanian cities and prepared by Algimantas Miškinis and his colleagues (Miškinis 1974; 1991; Lietuvos... 2005). In relation to the modernist notions of urbanism, some failures identified in our case are analogous to those of the new towns in the United Kingdom (Karimi et al. 2009). Using the spatial accessibility model of Vilnius city, the study focuses on spatial structure at the level of urban blocks constituting local centres. The use of the model for a simultaneous analysis of the relationship between urban composition and spatial accessibility values is expected to be an effective basis for showing the importance of strengthening the role of urban composition on macro and micro scales. The linear elements of the model are overlaid on a ground plan where convex spaces are highlighted considering their artistic and visual potential. Choice (betweenness, a measure of centrality) as a critical measure for analysing local centres is used to identify movement related structural patterns.

When looking into urban composition, the following criteria are selected as the main determinants of the artistic and visual potential of urban space: the transparency of facades, the character of frontages and other bounding elements and the visibility of a dominant building. The objective evidence is gathered through field observation and by studying the ground plan.

\section{Scientific Novelty}

This dissertation aims for introducing a new, scarcely studied aspect regarding the role of urban composition on macro and micro scales ensuring the functional and spatial order applied by integrating the potential of methods for analysing functional and compositional structures.

While using geometric models, the main features of the interrelationship between functional and compositional structures in local centres have so far been studied fragmentarily. Some research projects (Conroy Dalton, Bafna 2003; Claramunt, Winter 2007) were aimed at revealing the relationship between spatial accessibility values calculated and assigned to linear elements and the distribution of important elements of compositional structure (axes, nodes, dominant elements, etc.). This dissertation seeks to combine functional and compositional aspects of investigation into urban structure, i.e. identify a location and the role of local centres at both global and local levels and analyse the properties of urban composition defining the character of public spaces.

Proposed and developed through investigation into local centres in Vilnius, the method is based on the synthesis of worldwide used space syntax techniques and methodological recommendations for the analysis of the compositional structure of 
Lithuanian cities. Using the developed model for investigating interdependence between functional and compositional structures of the city, a study on local centres in Vilnius, focusing on their location and role, was carried out, which continued with a detailed analysis of three local centres in the north-west part of Vilnius.

By summarizing the results of the study, the possibilities of tackling with the problems related to the incomplete/ineffective plan of the existing local centres and providing solutions in order to prevent these problems while implementing urban design projects of new local centres have been revealed.

\section{Practical Significance of the Results}

The model for analysing the interdependence between functional and compositional structures of the city and the results achieved provide an opportunity to continue research on other actual cases as well as integrate the above described methods into a design process.

\section{Defended Statements}

1. Based on the results achieved by studying local and global properties of urban space, taking into account the role of urban composition and comparing findings of other researchers, the study proposes that an effective urban layout is one of the main factors making movement and social interaction in urban spaces possible.

2. In order to understand the importance of the coincidence degree of local and global properties to the formation of local centres, the diagnosis of the role of urban composition makes it possible to better explain the inconsistencies related to the incomplete/ineffective plan.

3. The model for analysing interdependence between functional and compositional structures of the city, which integrates mathematical and graphical modelling tools, could be used for defining formation principles of an effective urban structure.

4. The proposed interpretation of research findings and concluding remarks could be useful for integrating the above described methods, particularly aimed at solutions to urban space formation, into a design process, i.e. to arrange compositional axes that turn into interconnected functional axes ensuring the functional and spatial order, the interrelationship of urban elements, connectivity, accessibility and social interaction when the project on urban development is implemented.

\section{Approval of the Results}

Five articles focusing on the subject of the dissertation have been published: three articles - in peer-reviewed academic journals (Bučys 2009; 2010; 2013), one article - in peer-reviewed proceedings of an international conference (Bučys 2012) and one article in peer-reviewed proceedings of a national conference (Bučys 2008). Six presentations on the subject have been made in conferences at national and international levels. 


\section{Scope of the Scientific Work}

The dissertation consists of the introduction, three chapters, conclusions, a list of literature, a list of the author's publications on the subject and annexes. The total scope of the dissertation - 124 pages, 17 pictures, 17 tables and 4 annexes.

\section{Theoretical Background for Investigating Functional and Compositional Structures of the City}

The main proposal is that the methods for analysing space can be improved through investigating the role of urban composition on macro and micro scales, thus ensuring the coherence of the elements of urban structure.

The term 'composition' can be referred to as an urban layout which is a part of urban design that deals with the arrangement of buildings as well as convex spaces and/or the elements of the urban grid. Compositional structure is the arrangement of the aforementioned elements and the whole of the relations between these elements. Compositional analysis deals with spatial patterns using convex and axial abstractions of public space (convex spaces and linear elements), which is visual representation and description of the patterns.

The term 'functional structure' is used in an attempt to tackle questions related to social, economic, cultural and environmental processes within the city. Movement is considered to be a dominant form of space use. Occupation means the use of a building for commercial, domestic and other activities. Accordingly, functional structure refers to both the pattern of movement in space and the distribution of land uses. A street network can be represented as the least set of the longest lines passing through each convex space (Hillier, Hanson 1984). Space syntax brings to light functional structure when particular spatial accessibility values are assigned to linear elements.

Functional and compositional structures are closely linked and dependent on each other. Spatiality and axiality are assumed as fundamental concerns for research aimed at a better understanding of the interdependence of functional and compositional structures. In self-organized cities, compositional structure is usually constructed on the basis of functional structure. Differently, creating compositional structure first is a sign of the time. In this case, functional structure emerges after new compositional axes are connected to the existing street network. This is evident when dealing with districts in the analysed part of the city (in our case Vilnius, Lithuania) having predominant residential land use developed in a large area at one time.

The "separate" (i.e. "non-combined") approach to functional and compositional aspects of the formation of urban structure had a negative impact on those districts and their centres; it ignored the historic function of the street: the integration of movement and social interaction. The focus is on local centres because of their capability to bear on sustainability primarily through the collection of various functions defined as a concentration and mix of land uses and activities in a prominent location (Hillier 1999).

A new point in the combined approach is the introduction of the concept of dominance referring to a building as the most visually dominant feature in its urban context. The analysed problem of coherence between functional and compositional structures is 
also seen through the prism of dominant patterns embedded in urban space. There are two types of dominance (relationship) reflected in our case. First, the buildings characterised by the properties of height and volume (those contributing to visual impact in terms of scale and massing) in relation to land use should be pointed out. Second, investigation focuses on the close-up of a spatial accessibility (local and global) map and a convex map where spaces are highlighted according to their artistic and visual potential.

\section{Investigation into Urban Structure in the Local Centres of the City}

The selected examples of three local centres in the north-western part of Vilnius are treated as problematic areas where further interventions are needed. Two of those centres have problems concerned with their location. However, the points identified in the case study could be related to the incomplete/ineffective plan of each analysed local centre.

Districts and their centres in the analysed part of the city have predominant residential land use and were formed within the period of industrial construction dated from 1977 to 1991; before, the territory was mainly used for agricultural purposes. The new elements of the urban grid caused all three districts to have a distinctive character, but when looking at their local centres in the context of the whole city, the lack of connectivity is evident, i.e. not all potential connections were considered enough in order to link local centres to each other and to the global routes throughout the city. Therefore, Ukmerges Street remained the main functional and compositional axis leading to the historic city centre. The major problem is that this street was designed as a transport corridor diminishing the possibilities of social interaction.

The surrounding street network plays a key role in determining the potential of the area. However, it seems that separate groups of architects and planners involved in the process of forming new residential districts treated the given site independently, thus not trying hard enough to make the right connections between neighbouring local centres. This disregard can be partly explained by taking into account the notion that each district was planned making every endeavour to achieve an individual character (Miškinis 1991). The usage of mass-produced building components, standardization and unification had a negative impact on architectural possibilities. Therefore, in order to achieve the aforementioned goal, efforts were concentrated on the "innovative" arrangement of the urban layout.

Most of the failures concerning the spatial layout were programmed in the conceptual schemes of districts consisting of large residential buildings and separate commercial buildings/complexes set back from the street. There could be identified two main problems evident in the analysed part of the city: (1) the interwoven structure of public and private/semi-private convex spaces leading to the condition of over-permeability; (2) wide streets surrounded by the under-used areas of the lawn, surface car parking or indifferent and monotonous frontages. The first problem can be tackled by revealing cases where the same convex element can be considered both public and private. The second one is used for investigation by looking at the distribution of land uses and providing opportunities to transform/add the elements of built-up structure. Both problems that 
emerged as a result of planning decisions, made in order to separate pedestrian and vehicle flows, have to be approached by analysing the accessibility and degree to which spaces are constituted by building entrances.

One of the objectives developing a method for analysing compositional structure is to reveal the arrangement and interrelationship of dominant buildings, compositional axes and nodes. By investigating compositional structure, a visual and artistic potential of public space is determined considering its dependence on the observed features of the elements of the built-up structure.

Figure 2.8 shows the relationship between compositional axes and dominant buildings. We have identified two models consisting of a dominant building (shown as a circle) and appropriate visual connections (dotted line) (a). When a compositional axis (black line) is leading directly to the dominant building, visual connection is always ensured, but, if the compositional axis is extending close to the dominant building, then, visual connections depend on the arrangement of the elements of the built-up structure that create boundaries in urban space:

- Visual connections overlap with the compositional axis (Type 1);

In the first model, the dominant building is highly visible because of the ensured visual connection with the compositional axis leading directly to the dominant building. The opposite situation is identified in the second model where the dominant building is not visible when visibility is obstructed by the elements of the built-up structure, i.e. the dominant building is "hidden" (b).

- Visual connections partially overlap with the compositional axis when visibility is not obstructed by visual barriers (Type 2);

In the first model, the dominant building is highly visible because of the ensured visual connection with the compositional axis leading directly to the dominant building. However, visibility from the linked compositional axes is obstructed by visual barriers. The second model demonstrates that visibility is obstructed by the elements of the builtup structure, except for one point on the compositional axis from which the dominant building is visible (c).

- Visual connections partially overlap with the compositional axis when visibility is not obstructed by natural barriers (Type 3);

In the first model, the dominant building is highly visible because of the ensured visual connection with the compositional axis leading directly to the dominant building. Equally, visibility from the linked compositional axes adjacent to natural barriers (for example, the edge of a river, lake or sea) is not obstructed. The second model demonstrates two points on the compositional axis from which the dominant building is visible when visibility is not obstructed by natural barriers (d).

To develop an approach to evaluating streets, squares and other public spaces, the criteria of urban composition, including completeness, importance and character distinctness, have been considered (Table S1). The criteria have been selected using the principles closely related to route choice (as well as a mean of transport choice) and possibilities of social interaction in public spaces: 1) public spaces distinguished for their complete composition and established frontages; 2) their relative importance depends on unique, easily recognizable and understandable places (for visiting, meeting, interacting); 3) the distinctness of the character of public spaces depends on a degree of 
the openness or transparency of the built-up elements as the openings of windows and doors as well as glazed shop fronts create an impression of openness and transparency and have an impact on public space to become vital and intensively used.

Table S1. Description of evaluative criteria for urban composition

\begin{tabular}{|c|c|c|c|}
\hline \multirow[b]{2}{*}{ Value in points } & \multicolumn{3}{|c|}{ Description and evaluative criteria for urban composition } \\
\hline & Completeness & Importance & $\begin{array}{l}\text { Distinctness of } \\
\text { character }\end{array}$ \\
\hline High & Complete. & Important. & Distinct. \\
\hline 5 points & $\begin{array}{l}\text { Continuity of street } \\
\text { elevations is } \\
\text { maintained }\end{array}$ & $\begin{array}{l}\text { Dominant building is } \\
\text { the main element of } \\
\text { the built-up structure }\end{array}$ & $\begin{array}{l}\text { Openings of windows } \\
\text { and doors are } \\
\text { predominant elements } \\
\text { of facades; the main } \\
\text { entrances to buildings } \\
\text { prevail }\end{array}$ \\
\hline Medium/high & Complete. & Important. & Distinct. \\
\hline 4 points & $\begin{array}{l}\text { Some incomplete } \\
\text { elements in street } \\
\text { elevations }\end{array}$ & $\begin{array}{l}\text { Dominant building is } \\
\text { visible from certain } \\
\text { points inside convex } \\
\text { space }\end{array}$ & $\begin{array}{l}\text { Some blank walls and } \\
\text { other non-transparent } \\
\text { elements of facades }\end{array}$ \\
\hline Medium & Medium completeness. & Medium importance. & Medium distinctness. \\
\hline 3 points & $\begin{array}{l}\text { Almost an equal } \\
\text { proportion of complete } \\
\text { and incomplete } \\
\text { elements in street } \\
\text { elevations }\end{array}$ & $\begin{array}{l}\text { No dominant building } \\
\text { within convex space, } \\
\text { though some } \\
\text { dominant buildings } \\
\text { are visible in the } \\
\text { distance }\end{array}$ & $\begin{array}{l}\text { Almost an equal } \\
\text { proportion of blank } \\
\text { facades and those } \\
\text { having openings of } \\
\text { windows and doors to } \\
\text { buildings prevail (i.e. } \\
\text { with no windows and } \\
\text { main entrances) }\end{array}$ \\
\hline Low/medium & Incomplete. & Unimportant. & Characterless. \\
\hline 2 points & $\begin{array}{l}\text { Only some complete } \\
\text { elements in street } \\
\text { elevations }\end{array}$ & $\begin{array}{l}\text { No dominant building } \\
\text { within convex space, } \\
\text { though some } \\
\text { prominent elements } \\
\text { of the built-up } \\
\text { structure are visible } \\
\text { from certain points } \\
\text { inside convex space }\end{array}$ & $\begin{array}{l}\text { Few facades where } \\
\text { openings of windows } \\
\text { and doors to buildings } \\
\text { prevail or facades are } \\
\text { in the distance from the } \\
\text { street }\end{array}$ \\
\hline Low & Incomplete. & Unimportant. & Characterless. \\
\hline 1 point & $\begin{array}{l}\text { Continuity of street } \\
\text { elevations is not } \\
\text { maintained; incomplete } \\
\text { elements in street } \\
\text { elevations prevail }\end{array}$ & $\begin{array}{l}\text { No dominant building } \\
\text { within convex space; } \\
\text { indifferent and } \\
\text { monotonous elements } \\
\text { of the built-up } \\
\text { structure prevail }\end{array}$ & $\begin{array}{l}\text { Blank elements of } \\
\text { facades and blank } \\
\text { fences prevail; an } \\
\text { insufficient number of } \\
\text { the main entrances to } \\
\text { buildings }\end{array}$ \\
\hline
\end{tabular}


By performing field observation and studying the ground plan for evaluating the urban composition of public spaces, every linear element is assigned the value from 1 to 5 points in terms of completeness, importance and character distinctness. The category of public space is based on the total sum of points that a particular segment is assigned using three criteria. The first and highest category of public spaces (total sum makes 1115 points) includes those having complete composition and a distinct character determined by the presence of a dominant element (i.e. the dominant building is visible from any point inside convex space and has a dominating visual impact upon the street scene) and openings of windows and doors as the predominant elements of facades. Public spaces characterised by indifferent and monotonous elements of the built-up structure and urban space fall into the second category (total sum makes 6-10 points). The third category of public spaces (total sum makes 3-5 points) includes the ones edged with undeveloped plots and having predominantly unformed bounds, blank frontages and blank fences.

Completeness is the quality of urban composition that ensures the coherence and perfection of streetscape and urban layout (this is valid if streetscape and urban layout do not contain any major imperfection). It can be recognized that complete convex spaces have an elaborated form, i.e. street elevations are completely formed and the continuity of street elevations is maintained (high completeness; 5 points). On the contrary, any imperfection of urban composition prevents from seeing a clear view of the city or a part of it. Any incomplete elements and undeveloped plots, even if they constitute a small part of the whole length of street elevations (for example, under-used areas of the lawn or surface car parking), accounts for the value of 4 . In case of almost an equal proportion of complete and incomplete elements used in street elevations (if the exact length of street elevations is required, it can be measured on the ground plan), a segment is assigned the value of 3 . Medium completeness is also to be diagnosed when street elevation, because of natural features (topography, parks, woods and other natural barriers), is formed on one side of the street (for example, the other side may be unused for construction because of a steep slope, a preserved group of trees or a woodland). When the continuity of street elevations is not maintained, a segment is accordingly assigned the value of 2 and the value of 1 in the case of the prevalence of incomplete elements in street elevations.

Importance is the quality of urban composition when particular convex space has a strong impact on visual and artistic potential by the presence of a dominant element of compositional structure. When the compositional axis is leading directly to the dominant building and visibility is not obstructed by the elements of the built-up structure, visual connection is always ensured (see Fig. 2.8. Model 1; Type 1, 2, and 3), a segment is accordingly assigned the value of 5 and the value of 4 in case of the presence of visual barriers. When evaluating the importance of public space, it is not enough to notice the fact that the dominant building characterised by the properties of height and volume is the main element of the built-up structure. It is essential to consider prominent functions and land uses categorized as representative, i.e. administrative, religious, governmental and community, as well as the so-called active land uses, for instance, retail, catering, services, etc. The functions of isolated high-rise residential and office buildings are usually not included. Consequently, the urban composition of public spaces that do not 
have the aforementioned functions is treated as of medium to low importance. In the case of no dominant building within convex space, though the dominant building is visible in the distance, for example, is the main element of the built-up structure in contiguous convex space (see Fig. 2.8. Model 2; Type 2, and 3), a segment is assigned the value of 3 . The following two cases, when the urban composition of public space is treated as unimportant, are defined: a situation when no dominant building within convex space can be seen, though some other prominent elements of the built-up structure are visible from certain points inside convex space (low/medium importance; 2 points); indifferent and monotonous elements of the built-up structure prevail (low importance; 1 point).

Evaluating the distinctness of character (when facades are formed using the principle of transparency), it is essential not only to identify the degree of the openness of facades, but also to mark the main entrances to buildings, and in some cases, entrances to a parcel (or internal courtyard). The distinctness of character is primarily determined by the architectural properties of the buildings that allow the relationship between interior and exterior spaces and provide conditions for the exploitation of a building for commercial or other use. This allows establishing public space intensively used and appropriate for meeting and exchange. As a contrast to the implementation of the principle of openness, blank frontages or fences are undesirable as they prohibit from creating conditions for social interaction. In the event of few facades where openings of windows and doors to buildings prevail or facades are in the distance from the street (for example, when under-used areas of the lawn or surface car parking are separating entrances to buildings from the street), urban composition is treated as characterless and a segment is accordingly assigned the value of 2 ; the value of 1 is agreed in cases of the prevalence of blank elements of facades and blank fences and with reference to an insufficient number of the main entrances to buildings.

\section{Principles of Urban Structure Formation in the Local Centres of the City}

The first analysed local centre in terms of construction time and distance from Vilnius Old Town is situated in Šeškine district. The strength of this centre is global accessibility. It is located on both sides of the main route to the historic city centre and can be easily found and accessed by a large number of individuals, including passers-by. The other two centres (discussed further below) located on less significant routes and hidden within the local urban grid are visited mostly by the locals.

The problem is that Šeškinès Street - a crescent-like element in the radiating street pattern - consists mostly of indifferent and monotonous elements of built-up structure and urban space. Large spaces are dominated by surface car parking and set-back areas along the street with no functions. Economic and social activities are concentrated inside the quarter along pedestrian streets. During the last two decades, the distribution of active land uses has changed slightly from the pre-determined plan. The flower market was expanded and new office buildings were built (some parts of the urban landscape of the street has been improved). Naturally, there emerged several new non-residential functions along the street showing that the current situation as opposite to the strict sepa- 
ration of land uses and pedestrian/vehicle movement leading to some inconsistencies in the spatial patterns is a response to the constant pressure of change.

Designed mainly for vehicle movement, Ukmergès Street, consisting of a number of non-constituted convex spaces, divides the centre into two parts. The major constraint of the eastern part is the direction of the main axis of the pedestrian street. A failure in its original objectives is reflected by the insufficient number and mix of active land uses. In that case, only few office and residential buildings emerged, though comparing to the western part, the lack of land uses sensitive to movement is evident. This inconsistency can be identified by studying the ground plan. The aforementioned linear element parallel to Ukmergès Street neither performs as a line of global movement, nor is the presence of dominant buildings sufficient to dominate the surrounding area.

The local centre of Fabijoniškes consists of two parts. One of them (the so-called pre-determined part) is a pedestrian area with a complex of non-residential buildings (retail, public office, services, catering etc.) which adjoin it to the east proposed in the conceptual scheme of the district. A large space to the west of the pedestrian area underused by everyday activity is the result of an incomplete plan and unsuccessful implementation of the intended design. The other part was gradually formed on both sides of the parallel street during the last two decades. This shift can be ascertained by analysing the degree of the coincidence of local and global properties and verified by comparing the processed results to the findings of the study of local centres in London (Hillier 2009).

The urban layout of Fabijoniškès district can be characterised as a combination of grid and cul-de-sac. This prevents natural movement through the pre-determined part the accessibility to which by car or public transport is inconvenient. A newly formed part located on S. Stanevičiaus Street has significantly higher global accessibility. However, despite its disadvantages that are more dispersed active land uses as well as the underused areas of the lawn and surface car parking surrounding the street, this part has more potential to be developed into a spatially successful local centre. The location is very convenient for public transport users and further improvements in terms of complete composition and a distinct character sustained by the constitutedness of urban space are needed to offer more advantages for pedestrians.

A similar and in a sense even more complicated situation can be identified in the local centre of Pašilaičiai. The surrounding street network is actually more confusing. When looking at the conceptual scheme of the district, it can be noticed that the focus was concentrated on "innovative" arrangement and an attempt to combine the circular and regular grid-like network of streets. The need to make effective connections with the surrounding urban grid was somehow disregarded. Connections with Laisvès Avenue, particularly segments having the highest global accessibility in the context of the whole district, can be taken as an example. The main axis is reserved for pedestrian use only; moreover, no openings of entrances to residential buildings along this linear element (entrances are located in semi-private yards) could be found. Except for the fact that the complex of buildings reserved for commercial purposes can be considered as a dominant element surrounded by the under-used areas of the lawn, the other observed features (the openness of facades, the character of frontages and other bounding elements etc.) do not indicate that composition is complete and convex spaces constituting the local centre could not fall into the highest category. 
The first key principle is to ensure connectivity at both global and local levels, i.e. to connect local centres and their context as well as the main routes leading to other parts of the city. Along with a possibility of traversing every local centre using easily understandable routes, a network of interconnected local centres emerges, whereas at the local level the key point is to provide access to a range of shops and local services that meet everyday needs as well as to educational institutions and places for recreation and work.

The second key principle is to strengthen the role of urban composition on macro and micro scales. The results of the study show that made decisions giving a priority to tackle with functional aspects of the formation of urban structure, for example, the separation of vehicle and pedestrian movement ignoring the street as a place for meeting and exchange and failing to provide appropriate conditions for social interaction, causes an incomplete/ineffective urban layout related to unrealized artistic and visual potential, and, consequently, limited possibilities of vital public spaces to emerge.

When implementing the second principle, a comparison of presented urban composition and spatial accessibility values (see Fig. 2.9-2.14) as a step towards a better understanding of the analysed parts of the city as well as their features determining a spatially successful local centre are considered. The scope of investigation is to reveal if an artistic and visual potential of convex spaces constituting the local centre is effectively realized. The results of the study allow identifying segments with lower values of urban composition and spatial accessibility and applying specific tools in order to improve both, the architecture of individual buildings and the quality of public spaces. Although such problematic areas are likely to be found in the most actively used public spaces, they also can be at the edge or outside the local centre.

Three examples presented in the thesis demonstrate pedestrian routes leading to the most active parts of the analysed local centres.

- Route 5 (see Fig. 2.9-2.10);

Easily accessible public spaces constituting the local centre fall into the first and second categories. An exception is the segment crossing Ukmergès Street that falls into the third category. The segments traversing Šeškinès market have the lowest spatial accessibility values at both local and global levels; however, the urban composition of public space falls into the first category.

- Route 15 (see Fig. 2.11-2.12);

Low spatial accessibility values as well as urban composition values can be found in public spaces both at the edge and outside the local centre. When approaching the main attractors, urban composition values change to higher, i.e. the main pedestrian path is of the second category. A corridor-like passage for pedestrians has the highest spatial accessibility values, however, the urban composition of public space falls into the second category as the assigned values of the importance and distinctness of character are low.

- Route 26 (29) (see Fig. 2.13-2.14);

To compare public spaces at the edge and outside the local centre, spatial accessibility values are slightly higher when approaching the main attractors. Public space reserved for pedestrian use only and blank frontages, under-used areas of the lawn and surface car parking are the predominant elements. This is the main reason why the pedestrian path leading to the local centre falls into the third category. 
Architects as well as other actors involved in the urban design process understand that their freedom is not complete; usually they have to rely on decisions that are in compliance with commonly accepted development principles and traditions, the socalled 'social logic of space', i.e. the formation of the urban structure of local centres as a process has its natural limits. Establishing unnatural limits to urban growth or, otherwise, conditions for disproportionate concentration or spontaneous development could cause resistance from local communities or necessitate a counteraction strategy in the future.

\section{General Conclusions}

1. Using the model for analysing interdependence between functional and compositional structures of the city, which integrates mathematical and graphical modelling tools, the interrelated functional and compositional aspects of the formation of urban structure have been tackled: the features of the structure closely related to a hierarchy of centres and sub-centres have been assessed, and, as an effective basis, the model has been used at the local level for evaluating the distribution of pre-determined functions and urban composition.

2. The model for analysing interdependence between functional and compositional structures of the city is a reflection of artistic and visual potential as well as social and economic processes taking place in the city. Creating compositional axes and nodes has to be informed by analysis based on the models of the street network. This can be achieved by combining the two quantitative methods, using an analytical computer software for measuring spatial accessibility and through field observation investigating the role of buildings that shape urban space.

3. Based on three criteria of urban composition, i.e. completeness, importance and character distinctness, the evaluation of urban composition concentrates not only on the comparison of selected convex spaces constituting local centre, but also helps with revealing differences in the spatial structure as well as an artistic and visual potential of neighbouring local centres. Higher values of urban composition mean that artistic and visual potential is effectively realized. The lowest values reveal some locations requiring the reconsideration of their spatial and functional performance in order to come up with design solutions, including the arrangement of dominant buildings, compositional axes and nodes.

4. We suggest the evaluation of both local and global properties of urban space and urban composition in order to better understand the analysed parts of the city and their context and make strategic decisions on strengthening the role of urban composition. The procedures aimed at identifying the categories of convex spaces and comparing them with calculated spatial accessibility values allow disclosing spatial potentialities and predicting possible changes in the qualitative characteristics of public spaces. 
5. The use of two key principles - to ensure the connectivity of urban elements at both global and local levels and to strengthen the role of urban composition on macro and a micro scales - and consequently, design solutions are essential for exploiting the possibilities of the existing structure in order to achieve urban sustainability and ensure effective functioning of urban structure. The proposed means for rearranging the structure of an urban grid in local centres in Šeškinè, Fabijoniškès and Pašilaičiai are the introduction of new links with the surrounding street network, remodelling the existing junctions and building new streets inside residential districts designed for lower speeds. Using undeveloped sites, orientating new buildings to front the street and improving the architecture of the existing buildings to ensure the relationship between interior and exterior spaces allow forming complete public spaces having a distinctive character. 


\section{Priedai ${ }^{1}$}

A priedas. Vilniaus miesto viešujų erdvių pasiekiamumo schemos

B priedas. Šeškinès, Fabijoniškiụ ir Pašilaičiụ lokalius centrus sudarančių viešujjụ erdviụ nuotraukos

C priedas. Šeškinès, Fabijoniškiụ ir Pašilaičių lokaliụ centrų funkcinès ir kompozicinès struktūrų analizès duomenys

D priedas. Autoriaus mokslinių publikaciju disertacijos tema kopijos

${ }^{1}$ Priedai pateikiami pridetoje kompaktineje plokštelèje. 
Justinas BUČYS

MIESTO LOKALIỤ CENTRỤ FUNKCINĖS IR KOMPOZICINĖS STRUKTŪRŲ SĄVEIKA

Daktaro disertacija

Humanitariniai mokslai,

Menotyra $(\mathrm{O} 3 \mathrm{H})$

INTERDEPENDENCE BETWEEN FUNCTIONAL AND COMPOSITIONAL STRUCTURES IN THE LOCAL CENTRES OF THE CITY

Doctoral Dissertation

Humanities,

History and Theory of Arts $(03 \mathrm{H})$

201310 04. 12,0 sp. I. Tiražas 20 egz.

Vilniaus Gedimino technikos universiteto

leidykla „Technika“,

Sauletekio al. 11, 10223 Vilnius,

http://leidykla.vgtu.lt

Spausdino UAB "Baltijos kopija“

Kareivių g. 13B, 09109 Vilnius 